\title{
ROOTED IN FERTILE SOIL: SEVENTEENTH-CENTURY DUTCH GARDENS AND THE HYBRID HISTORY OF MATERIAL AND KNOWLEDGE PRODUCTION
}

\author{
PROEFSCHRIFT \\ ter verkrijging van \\ de graad van doctor aan de Universiteit Twente, \\ op gezag van de rector magnificus, \\ prof. dr. H. Brinksma, \\ volgens besluit van het College voor Promoties \\ in het openbaar te verdedigen \\ op donderdag 16 december 2010 om 13.15 uur
}

door

Alette Andrea Fleischer

geboren op 17 februari 1963

te Amsterdam 


\section{Promotor}

Prof. dr. L.L. Roberts

Heeft het proefschrift goedgekeurd.

\section{(C) 2010 Alette Fleischer}

All rights reserved. No part of this publication may be reproduced, stored in a retrieval system, or transmitted, in any form or by any means, electronic, mechanical, photocopying, recording, or otherwise, without the prior written permission of the publisher.

ISBN

978-90-365-3097-2

DOI nummer $\quad 10.3990 / 1.9789036530972$

Vormgeving: Studiopunkt Bonn, Duitsland.

Druk: Ipskamp Drukkers, Enschede. 


\title{
ROOTED IN FERTILE SOIL: SEVENTEENTH-CENTURY DUTCH GARDENS AND THE HYBRID HISTORY OF MATERIAL AND KNOWLEDGE PRODUCTION
}

\author{
Alette Fleischer \\ University of Twente, the Netherlands \\ Faculty of STePs \\ Department of the History of Science and Technology \\ Promotor prof. dr. L.L. Roberts
}




\section{TO MY PARENTS}

Cover: Willem Buytewech, Allegory on the Twelve Year Truce, 1615, Atlas Van Stolk, Historisch Museum Rotterdam, Rotterdam 


\section{Table of content}

Acknowledgement

Introduction

Chapter one

The Beemster Polder: conservative invention and

Holland's great pleasure garden

Chapter two

Into the light: crystals and the recreation of nature

in seventeenth-century garden caves and cabinets

Chapter three

The Company's Garden and the (ex)change of nature and knowledge at Cape Of Good Hope (1652-1700)

Chapter four

Holland's hortus and Baltic botany: transforming and transporting 'mother nature' along the 'mother of all trades' route

Conclusion

Nederlandse samenvatting

Bibliography 


\section{Acknowledgement}

Every school holiday, my parents took my sisters and me to France. Not in a hurry - taking the route national instead of the motorway - it took us several days to reach our usual campsite in the Bordeaux region. My mother made sure to stop at various historical sites along the way. Before I reached my teens I had seen the cathedrals of Chartres, Beauvais, and Amiens, strolled along endless World War One graveyards, and visited half a dozen of Loire castles such as Amboise, Chambord, and Azay-leRideaux. I remember walking in the Renaissance gardens of Chenonceau following and admiring the geometrical patterns of paths and greens, while trying to imagine how French noblewomen had walked here long before me. My passion for gardens and history were planted there.

This passion developed into an academic career when I began to study art history at the Vrije Universiteit Amsterdam. Under the guidance of Professor Erik de Jong I researched the relationship between twentieth century art and nature by tracing the histories of two museum/sculpture gardens: the Kröller-Müller Museum (Otterlo) and Museuminsel Hombroich (Neuss). My master thesis opened the way for me to inquire into modern notions regarding nature: as a backdrop for the arts and as a reconstruction of nature.

By winning the NWO Aspasia award in 2003, I could proceed this research by focussing on seventeenth-century Dutch gardens gave rise to both natural inquiry and inventions. I saw this as a logical step to take. To move back three centuries in time allowed me to further research the ideas about nature's appearance, while the research subject allowed me to widen the perspective to include the production and consumption of knowledge and material that shaped and were shaped by gardening. My fascination for gardening nature in the broadest sense has motivated me to undertake this fast project, and I tried to pass this on to the reader.

Without the patient guidance of my professor and friend Lissa Roberts, her relentless encouragement and tireless trust into my ability to bring together the various difficult elements that came forth from this project, I would have strayed from the 
historical garden path and into dense woods. She has played a crucial role regarding my intellectual development, by stimulating my creative ideas and by helping me to kill my darlings. She opened doors for me that otherwise would have remained closed, by inviting me to participate in several conferences and by urging me to publish essays in journals and volumes. This meant for her more work, since she is not only my friend and mentor, but my editor as well as she brilliantly transformed my English into something worth reading.

At the University of Twente, my immediate colleagues on several occasions torpedoed me with questions, remarks, suggestions, and ideas to help straighten my thoughts and thus my work. With their often spot-on remarks and intellectual support, Nil Disco, Adri de la Bruheze, Fokko Jan Dijksterhuis, and Onne Bieringa, have been more than collegial. Moreover, I am very proud that Fokko Jan has agreed to be on my graduation committee to judge the finished product.

Furthermore, I like to express my deep regards to the other members of the committee of graduation, Professors Stefan Kuhlmann, Hal Cook, Jon Lovett, and Erik de Jong. Two of them I have known and respect for many a year, I am greatly thankful for Erik's and Hal's intellectual encouragement. I am grateful that Stefan and Jon willingly stepped outside their comfort zones and agreed to spend their precious time to read this dissertation and be on this committee.

On several occasions I have presented parts of this dissertation. My first time was at a KNAW Akademie Colloquium 'Inventive Intersections' in 2004 organized by Lissa Roberts together with Simon Schaffer (Cambridge University) and Peter Dear (Cornell University). I have presented a paper twice at a SHOT meeting (Amsterdam 2004 and Washington DC 2007) and at seminars at Cornell University Ithaca, Leiden, and Ghent). From various participants I have received helpful comments and suggestions, but I like to name a few in particular: Siegfried Huigen, Ian Inkster, Trevor Pinch, Ben Schmidt, Pam Smith, Johan Schot, and especially Simon Schaffer deserve special attention. They graciously allowed me to pick their brain, answered all my questions patiently, and suggested books and articles that proved to be greatly helpful for my research.

My work could not have been accomplished without the assistance of several librarians and archivists from, amongst others, Gerard Thijsse (Nationaal Herbarium Leiden), Mark Spencer (British \& Sloane Herbariums Natural History Museum, London), Andre van Noort (Regionaal Archief Leiden), various people at the Nationaal Archief, British Library, Waterlandsarchief, Special Collections department of the University of Amsterdam and the University of Leiden, the Haags Gemeentearchief, and the Koninklijk Huisarchief. 
ACKNOWLEDGEMENT

Finally there are two men I need to thank for their efforts to encourage me to go on and who endured my ups and downs: Sjaak Beemsterboer and Tom Rooduijn. Furthermore, Sjaak has been responsible for the lay-out of my dissertation, and Tom has edited the Dutch summary. And of course I thank my mother, my family, and friends who have supported me by encouraging me, picking me up, reading drafts, cups of coffee, and never moaned that I neglected them.

Amsterdam, December 2010 


\section{Introduction}

\section{Rooted in fertile soil: Seventeenth-century Dutch gardens and the hybrid history of material and knowledge production}

In 2003, the Dutch Organization for Scientific Research (NWO) funded a new research programme entitled "Inventive Intersections: Sites, Artefacts and the Rise of Modern Science and Technology." The goal of this programme as conceived by its author Lissa Roberts, was to move away from the a-historical distinction between "science and technology" and approach early modern European natural inquiry and invention by focussing on sites and artefacts "that provided points of intersection for the activities and interests of a broad range of actors who engaged with nature and art." "This resulted in a three-day colloquium in Amsterdam in 2004 and the volume The Mindful Hand; Inquiry and Invention from the Late Renaissance to Early Industrialisation. ${ }^{2}$ Part of this programme included a dissertation project described by the title "Rooted in Fertile Soil: Seventeenth-Century Dutch Gardens, Natural Inquiry and Technology." The original proposal called for portraying gardens as inventive interactions and suggested using several types of Dutch gardens, such as botanical and urban gardens, county estates, and labyrinths, to further our understanding of early modern natural inquiry and invention.

By studying the hybrid histories of gardens, the Republic, natural inquiry, and invention in the Golden Era, this dissertation aims to show that contemplating and manipulating nature are two faces of the same coin. Gardening is a way of conducting natural inquiry and invention in order to control and govern landscapes. Many mindful hands and handy minds undertook this seemingly mundane activity. By researching these combined histories, this dissertation defies the notion that artisans or manual workers applied 'theories' put forward by scholars. Just as mathematicians, philosophers and amateurs were busy with ordering and explaining nature, so were artists, gardeners, artisans, engineers, mill-wrights, miners, nomads, farmers, and seamen able to shape and understand nature. All were busy, in their own way and often jointly, with producing skilful knowledge and sensible inventions.

This research project's basic argument is that Dutch gardens formed 'fertile soil', but not only because of the application of natural inquiry and invention by a broad 
range of actors and objects (each with their own trajectory of interests and goals) who met there. Gardens simultaneously provided the ground in which further inquiry and invention were rooted and from which they stemmed. Through their joint contemplative and manipulative actions, philosophers, doctors, merchants, courtiers, governmental and private patrons, artisans, apothecaries, gardeners, botanists, and engineers, reformed nature. At the same time, gardens enabled new ways of understanding and manipulating the world.

Along the way, this project revealed an even richer and more complex history than originally described. The history of gardening indeed took place in 'sites of inventive intersection', and involved the hybrid activity of hands and minds which together creatively and purposefully amalgamated nature and artifice. It further depended on the continual movement of people, plants, books and so forth, which traversed various routes and connected the local with the global. It relied as well on mediators who allowed for the exchange and transformation of knowledge and nature as will be explained below. In keeping with these characteristics, this dissertation discusses four case studies which highlight the richness of this research question from various, sometimes overlapping, angles. The purpose is to present Dutch gardens not only as places of inventive intersection, but also in terms of the complex hybridity of gardens, the transformation and circulation of nature and knowledge, the geography of botanical knowledge and the role of go-betweens in the construction of gardens and natural knowledge.

As it proceeded, this research project incorporated a number of analytical perspectives, using mostly sociological viewpoints, and bringing global history into the fields of 'local' gardening, inquiry and invention. The four case studies can be read as 'stand alone' essays; three chapters have already been published as articles in volumes and journals, and the fourth chapter is under consideration. ${ }^{3}$ However, these four chapters are simultaneously interconnected and provide insights into the historical setting for the dissertation as a whole, that is, the world of the Netherlands during the seventeenth century.

This dissertation starts with a drainage project: the Beemster polder. This was considered as a vast garden that showcased the paradoxical and hybrid Dutch ideal of engineered, pristine nature. Among other things, the examination of this history builds on the concept, introduced by historian of technology Thomas Hughes, of 'conservative invention' to show how controlled technological innovation combined with geometrical ability and vision to transform unusable water lands into a landscape rich in commercial, aesthetic and religious significance. ${ }^{4}$

The second case follows the movement and translation of crystals from their original resting place in the 'bowels of the earth' to adornments on the walls of nobleman Hans Willem Bentinck's garden grotto and objects of inquiry in the pages of 
ROOTED IN FERTILE SOIL: SEVENTEENTH-CENTURY DUTCH GARDENS AND THE HYBRID HISTORY

OF MATERIAL AND KNOWLEDGE PRODUCTION

Christiaan Huygens' treatise on the nature of light. It shows how this transformative journey relied on the hybrid efforts of miners, political figures, noblemen, amateurs, and mathematicians as it gave rise to a multi-faceted economy of understanding and delight. Even Huygens, usually depicted as a philosopher, proves to have relied on his and others' manual dexterity as much as on his mental capacities. Ironically, this case concludes by claiming that the awe-inspiring surroundings of Bentinck's grotto proved more revelatory of the nature of the crystals with which it was encrusted than did Huygens' 'philosophical' inquiry.

If the geography of this study connects Dutch gardening and politics with German mining and the republic of letter's Parisian capital, the third case takes us even farther beyond the borders of the Low Countries. Beginning with an examination of the Company Garden established by the Dutch East Indies' Company (VOC) at the Cape of Good Hope, it goes further to consider South Africa more generally as susceptible to occupation and cultivation. Building on Richard White's concept of the 'middle ground', it discusses the changing balance between the VOC and South Africa's nomadic tribes who - often through the mediation of go-betweens - exchanged material goods and knowledge as each group sought to gain the upper hand. ${ }^{5}$ The ultimately stronger network of the Dutch allowed them to cultivate the Cape of Good Hope both on paper and by plough to further their (agricultural) conquest of South Africa.

In the fourth and final case, a rather different trajectory of commercial and knowledge production and exchange is presented. Here the focus is on the constitution of botanical knowledge at two nodes and the trade route that enabled the transportation of knowledge, matter, and people between both nodes. The cereal trade between Holland and Danzig, known as the Moedernegotie (the 'mother of all trades'), connected the estate of amateur Hieronymus van Beverningh near Leiden and the botanical activities of the merchant/botanist Jacob Breyne in Danzig. This case addresses the collection, transportation and transformation of perishable plants via the trade routes to and from Holland and Danzig. To put it in Latourian terms, botanists and gardeners transformed and resituated flora in mutable and immobile gardens such as Van Beverningh's, on one hand, and immutable and mobile paper gardens such as herbals, on the other. Alternations between these two, enabled through trade, link the local (various gardens and sites) to the global (through published books and the circulation of botanical knowledge).

These topics reflect the complex meaning of what a garden was in the Golden Era. It encompasses not only private and public gardens, but also agriculture, a polder, and plant books, as will be further discussed below. The choice of these four different gardens helps to unveil all aspects of gardening, starting with staking out territories, map-making, design, planting, collecting, manipulating, contemplating, 
and ending with recreating nature in etchings and books. Furthermore, these topics make clear that Dutch gardens are not confined to the Low Countries, but are part of a larger international network of the exchange of people and plants, and that some gardens formed nodes along the Dutch trade routes, before being shipped to the motherland. The cultivated fields in the Netherlands and abroad help us to further understand the importance of Dutch trade regarding the construction of knowledge and objects.

This introduction starts with a section that discusses the connections between the chapters, and presents the lessons that can be drawn from using Dutch gardens as a way to trace the common roots of natural inquiry and invention. The first section discusses the history of Dutch gardens in the seventeenth century, followed by a section on the hybrid histories of gardening and natural inquiry by connecting the histories of science and gardens. The following sections present the models used in this thesis, starting with Latour's circulation of knowledge and followed by a section on the role of go-betweens and the construction of a middle ground, and it concludes with a section on gardens and the concept of the mindful hand.

\section{Dutch gardens in the Golden Era}

... here we have many manors, pleasure gardens, country estates, princely houses and courts; close to Amsterdam we have the countryside around Leiden, The Hague, Haarlem, as well as the drained lakes: the rich clay soils of the Beemster, Schermer, Purmer, Wormer etc., and not forgetting the pleasure estates near the city of Utrecht along the River Vecht. ${ }^{6}[\ldots]$ In Holland, we can call ourselves fortunate, as all arts and sciences - such as strange rarities, delicacies, luxuries, yes treasures and riches - are bestowed upon us by God's benediction. $^{7}$

Jan van der Groen, 1670

When royal gardener Jan van der Groen summed up all the types of gardens found in Holland, he included pleasure gardens as well as entire drainages or polders. With God's Grace, the Dutch were able to turn chaotic nature into beautiful and profitable gardens. Furthermore the Dutch were blessed by having received a large wealth of natural treasures and artificial rarities, enabled by natural inquiry (sciences in Groen's wording) and inventions (to be understood as art and technology). Gardening, thus, entailed reconstructing and rethinking nature by using mental and manual artifice, aided by divine intervention. This hybrid activity combined the arts and the sciences to display natural and human treasures and rarities in a neat and orderly site. 
ROOTED IN FERTILE SOIL: SEVENTEENTH-CENTURY DUTCH GARDENS AND THE HYBRID HISTORY OF MATERIAL AND KNOWLEDGE PRODUCTION

What was the meaning of the word 'garden' in the Golden Era? A garden was an enclosed section of land where humans, aided by the arts, tamed wild nature into a cultivated land built for profit and ornament. In the seventeenth century, polders were perceived as gardens as it was a cultivated nature, sectioned off from its environment by dykes and canals, allowing agriculture and pleasure gardens to blossom. Herb books were also seen as gardens; in these paper gardens, enclosed by a cover, a reader could study and admire nature's rarities the whole year round. Lastly, a Dutch garden was a metaphor for the Republic created by and for its citizens and well protected against its enemies: water and the Spaniards with whom the Dutch had been at war for eighty years.

The transformation of wild and chaotic nature to cultivated nature was partly motivated by the Ciceronian ideal of an alteram naturam that was a cultural landscape with roads, bridges and fields. ${ }^{8}$ This managed nature was fit for habitation and consumption, opposed to untamed 'first nature'. It followed that gardens were considered a 'third nature', one that was not only husbanded but also beautified in the seventeenth century. For gardeners (as an all encompassing word for those men and women involved with gardens and gardening) there was also a biblical motivation for the contemplation and manipulation of nature: to expose its hidden order and to display and examine nature's rich variety and uniqueness. Gardening as a means of cultivating nature includes agriculture or 'second nature' that enabled produce to sustain humans. Medicinal and botanical gardens formed subtypes where vegetation was grown for its medical or exotic properties.

Transforming nature underscored the role of humans as a new Adam or manager of nature. This began by mapping or drawing nature (maps, charts, botanical books, Huygens' sketches) and resulted, for instance, in a drained land, botanical books, a garden grotto, a treatise, and an agricultural colonization, as this dissertation argues. All these examples showed the different representations of manmade and controlled natures filled with natural and artificial elements that simultaneously gave rise to a further understanding and management of nature. By mapping and fencing in sections of a surrounding environment, humans proceeded with the accumulation, examination, and manipulation of nature, while furthering their ongoing mental and manual possession of nature. ${ }^{9}$

In the seventeenth century, Dutch elite (regenten, wealthy widows, merchants, professors, and nobles) set and followed the socio-cultural rules to garden, reconstruct, and enjoy nature as a means to leading healthy and God-fearing lives, while examining and collecting nature's riches. The Dutch imposed geometry onto a landscape or specific site. Squares, rectangles, straight lines, and perpendicular elements dominated a garden, whereby the terrain was raised or flattened to make it more 
even. A garden was a hybrid object of nature and artifice, filled with imported and exotic plants and artificial structures, which reflected a combination of skilful artistry over nature and the mercantile links with the Dutch trading companies to the East, the West, and the Baltic region.

Cultivating land was a way to demonstrate dominion over nature and the world as historian Chandra Mukerji argues, since engineering and managing the land brought profit and power to certain layers of Dutch society as it did for the French ruling class. ${ }^{10}$ Every aspect of gardening, ranging from mapping a terrain, pruning trees, constructing grottoes, digging canals, accumulating naturalia and artifice, collecting and compiling herb books, entailed aspects of contemplation and manipulation. At the same time, cultivating nature projected the desire to change wild nature into a controlled landscape; it motivated, for example, the colonization of the Cape of Good Hope, the drainage of the Beemster, and the construction of Bentinck's garden grotto. These gardening enterprises illustrated how Dutch 'gardeners' changed what they perceived to be uncultivated nature into an orderly garden. In two cases, a commercial conglomerate initiated these gardening activities, whereas in the third case, political ties lay behind the building of a garden-grotto.

Different groups of people, motivated by profit and curiosity, facilitated natural inquiry and invention in order to expand their agricultural conquest and curious accumulation of nature. Dutch gardens - as opposed to Mukerji's example of Versailles that was largely motivated by dominion and display of royal might that governs over nature and people - projected dominion as a combination of profit and commercial and political power. This took shape either in vast agricultural projects, through the display of nature's exotic treasures, and through the aesthetic understanding of nature.

\section{The hybrid histories of gardening and natural inquiry}

By focussing on Dutch gardens, this dissertation continues to argue that the hybrid practice of gardening entails an intricate connection between natural inquiry and invention and between mind and hand. ${ }^{11}$ The histories of gardens, trade, natural inquiry, inventions and the more general history of the Republic are intertwined, even though these histories have their own historiographies. Researching gardens and gardening bring together the hybrid history of the production of knowledge and material, and show that 'science and technology' are rooted in Dutch fertile soils while being part of a bigger picture.

From the mid-1930s, historian Alexandre Koyré and his proponents signalled a revolution in the history of science in the seventeenth century: an intellectual trans- 
ROOTED IN FERTILE SOIL: SEVENTEENTH-CENTURY DUTCH GARDENS AND THE HYBRID HISTORY OF MATERIAL AND KNOWLEDGE PRODUCTION

formation of scientific thought in the fields of mechanics, astronomy and physics. Koyré and others focussed on the histories of 'scientists' such as Galilei, Descartes, and Newton, whereby the last was placed onto the metaphorical shoulders of predecessors. ${ }^{12}$ Historian Edgar Zilsel opened the way for historians to include the skilful knowledge of artisans in the history of science and he argued that early modern capitalism contributed to the rise of modern science. ${ }^{13}$ In the last thirty years the sociocultural perspective entered the histories of science and technology. The connection between culture, natural knowledge and technology had been successfully argued in Steven Shapin and Simon Schaffer's book Leviathan and the air-pump, that proved to be a turning point in the history of science. ${ }^{14}$

This dissertation steps away from more familiar actors and settings discussed by historians, such as the disinterested British gentleman's study; British and French philosophers; the royal science academies. ${ }^{15}$ Over time, the traditional 'big picture' history had repeatedly placed the origins and development of modern science and technology in France, England, and a little later in the United States. Now, both 'site' and 'big picture' history is under scrutiny, by amongst others Andrew Cunningham. ${ }^{16}$ Schaffer and Shapin have focussed on mainly British examples for their socio-cultural histories of science and technology. By placing the emphasis on these (dominant) countries historians paid less attention to the construction of natural inquiry and invention in other countries.

Recently, historians have brought to light the knowledge and material production and consumption that took place in German, Russian, Spanish, Dutch, and English colonies, and the Low Countries. Alix Cooper's Inventing the Indigenous and Harold Cook's Matters of Exchange are recent examples of historians who find that knowledge-making took place in Germany, the Low Countries and Asia. ${ }^{17}$ This thesis discusses two areas in the so-called periphery: the Cape of Good Hope and Danzig. These two regions were connected to the Low Countries by trade, but had not received as much attention from historians as the Dutch-Asian networks. The Cape and Danzig proved to have contributed to the circulation and production of knowledge and nature within their region and to and from the Republic, as chapter three and four show.

In garden history a lot of attention has been given to the aesthetic qualities of gardens that involved intricate geometrical shapes paired with notions about Divine Nature, classical Greek-Roman elements, garden sculpture, social status, and botany. Gardens, in short, are discussed as places of refuge against the unhealthy climate of city life and as repositories of artificial and natural rarities. Historians Erik de Jong and Vanessa Bezemer connect the interwoven aspects of art, nature, and culture in Dutch gardens. ${ }^{18}$ Technology and natural inquiry receive some attention from garden 
historians who signal that garden owners were interested in the various aspects of science - such as mathematics and astronomy - and that constructors and engineers were concerned with the technological aspects of gardening. However, gardens are not solely sites that form a backdrop of technology and natural inquiry, but gardens prove to be fertile soil for gardeners and amateurs who examined and reworked nature while gardening. These hybrid activities give gardens shape, while at the same time gardens shaped natural inquiry and invention. The hybrid practice of gardening encompasses a cooperative work undertaken by different types of 'gardeners'.

As historian Pamela Smith tells us, artisans through their learning and skill and their transformative work were active knowers of nature. ${ }^{19}$ Artisans produced and consumed knowledge of nature, which they combined with art to construct an element of enhanced nature. This dissertation joins historian Warren Dym by arguing against a hierarchy of knowledge consumption and production, of ideas, theories, and practices conceived by learned gentlemen that trickled down to the levels of workers or artisan..$^{20}$ Both groups 'tamed' nature according to their knowledgeable skills and helped to manipulate and understand nature's workings.

This concept of the hybrid practice of gardening can be found throughout this dissertation. In the first chapter on the Beemster Polder, for instance, it is argued that the hybrid activities of hand and mind co-constructively allowed for a recreation of God's Creation. Artisans, engineers, merchants, regenten, millwrights, and land surveyors collectively reshaped nature, while using and adapting their ideas of nature, and their 'tools' (art and technology) to expose Holland's pristine Nature. Likewise, chapter two, on the revelatory trajectory of crystals, conveys the theory that the gentlemanly pursuits of natural philosophy and the artful work undertaken by knowledgeable labourers followed similar paths along which the contemplation and manipulation of nature took place.

By following the Dutch 'gardeners' we have the opportunity to reveal the joint seventeenth-century roots of natural inquiry and invention, which later became known as 'science and technology'. Simultaneously, this helps us to reveal the connectedness of natural inquiry and invention to Holland's vast mercantile network; the commercial - and to a lesser extent political - force motivating the discussed hybrid garden practices and purposes. Dutch trading and knowledge network enabled the exchange of matter and facts, as Harold Cook has so extensively argued. ${ }^{21}$ The producers and consumers of Dutch private and botanical gardens, of agriculture and dominion, of books and bulbs profited from this vast trading network. Commerce and travel formed the trajectory along which local and exotic knowledge and matter circulated to and from Dutch gardens, which in turn gave further rise to the formation and adaptation of natural inquiry and inventions. 
ROOTED IN FERTILE SOIL: SEVENTEENTH-CENTURY DUTCH GARDENS AND THE HYBRID HISTORY

OF MATERIAL AND KNOWLEDGE PRODUCTION

\section{Circulation of knowledge and nature}

The original outline of this research called for examining individual sites, or inventive intersections in the Low Countries. As already discussed in the section above, gardening gave rise to centres where facts, artificial and natural matters shaped and were shaped to further enjoyment and examination of nature, inquiry, and invention. Holland's gardens formed part of a larger network and routes along which people, practices, and objects traversed. This movement of knowledge and matter went hand in hand with its transformation and local appropriation. In recent discussions on global history and the histories of science and technology the concept of 'circulation' has become increasingly widespread..$^{22}$ By using circulation in the context of gardening this dissertation can illustrate how the local and the global affected each other, and its interactions as it transformed Dutch gardens, botanical knowledge, agricultural practices, and even landscapes. The circulation of material goods and facts, and the travel of people and plants, underscored the global character of Dutch gardening while being so firmly rooted locally.

Through the Dutch trading and knowledge networks, gardens became sites where transported and transformed knowledge and nature entered, and became available for others to examine and enjoy. The ongoing circulation shaped the geography of the gardens by expanding its tentacle into distant regions. However, in order to fit into Dutch gardens - or other sites such as botanical books or agriculture - actors adapted the collected plants, inventions, and knowledge to meet local requirements. This transformative process helped Dutch 'gardeners', for instance, to reconsider nature's rich and diverse flora by discussing and comparing characteristics, nomenclature, and appearance in gardens and in herb books, as chapter four argues.

Sociologist Bruno Latour has propagated the circulation of people, knowledge, and objects in his book Science in Action. ${ }^{23}$ This method ensures that through circulation observations, inventions, letters, charts, and objects change shape and meaning. This research uses Latour's model to show how the accumulation, transportation, and transplantation of knowledge and materials led to other insights and inventions regarding natural inquiry, agriculture, botany, instruments, books, and minerals. Gardens, then, can be seen as centres of accumulation, where nature and knowledge came together. However, a garden also gave rise to knowledge and nature, thus it functioned at the same time as an inventive intersection. Closed off from its surroundings, a garden offered the opportunity to examine and experience nature's elements. Here, humans could construct the right circumstances to assemble and compare nature's rarities. This manipulation of nature was a communal activity of 'gardeners' who exchanged their findings with others, either by placing it in other 
gardens and publishing books, for example. These findings - be they technological, botanical, geometrical, or aesthetical - circulated from garden to garden, within the Republic or abroad. Each time these findings were adapted to meet local requirements.

Throughout this dissertation, we come across the movement of people, plants, papers, and objects. This movement transformed not only the Dutch garden, as travelling actors and transported objects, practices, and knowledge had to be adapted to the new environment. At the same time, circulation shaped distant habitats of natural matter affecting landscapes and peoples, as the history of the Company Garden informs us. Circulation forms, then, a way for us to rethink the imbalanced notion of a Western dominance over other parts of the world, as Lissa Roberts argues elsewhere. ${ }^{24}$ Indeed, as chapter three argues, the nomadic Khoikhoi of the Cape of Good Hope circulated and transformed Dutch knowledge and goods, just as the Dutch did from the locals.

Travel and circulation entailed a complex geography that undergirded the mundane act of gardening while giving rise to natural inquiry and invention in the Low Countries. It enabled an ongoing influx of unfamiliar flora, practices, and knowledge that called for examination and enjoyment at home. For instance, the travels of Constantijn Huygens helped to bring to light the German rock crystal and to have it transported to Paris where, in the mindful hands of his brother, the crystal was reworked into geometrically shaped objects of art and study.

However, we have to include the fact that through the circulation of knowledge and objects to and from Holland, both knowledge production and consumption happened inside and outside local Dutch sites and that it had had a global impact on the cultivation of nature. The next section discusses the concept of 'go-betweens' who facilitated the exchange, transformation, and dispersal of knowledge and goods to other people, environments, and Dutch gardens.

\section{Gardening and go-betweens}

The circulation of knowledge, nature, and matter relied on the active role of mediators who helped to obtain facts and matter. To use the concept of go-betweens as an analytical tool enables us to trace the negotiations and exchange that took place as part of - or prior to in some cases - the construction, transformation, and circulation of knowledge, objects, practices, and inventions. Go-betweens, such as interpreters, traders, factors, surveyors, and artisans were actively engaged in the production and 
ROOTED IN FERTILE SOIL: SEVENTEENTH-CENTURY DUTCH GARDENS AND THE HYBRID HISTORY OF MATERIAL AND KNOWLEDGE PRODUCTION

transmission of locally obtained goods, practices, and knowledge that they translated and transformed according to the desires of distant others and further circulation of knowledge, practices, deliberate misunderstandings, and cultural interpretations. ${ }^{25}$

In order to achieve their goals - set by themselves, a patron, or company - a go-between could help create and manage a site of interaction and exchange. ${ }^{26}$ Historian Richard White calls this site a 'middle ground' where the accumulation and exchange of useful or valuable matter took place. He defines a middle ground as a "place in between: in between cultures, peoples, and in between empires and the nonstate of world of villages." ${ }^{27}$ Changing rules, goals, and purposes changed the conventions surrounding a middle ground constantly. ${ }^{28}$ This demanded a flexibility of go-betweens, to manoeuvre between the demands and perceived desires of their kinsmen and that of the negotiating party. Go-betweens and their dealings on a middle ground could function between Dutch and African natives to negotiate trade and knowledge, but also amongst Dutch from different layers of society who tried to persuade the 'other' to cooperate in the joint quest for natural knowledge and invention, as chapter one and two discuss.

By discussing the concept of go-betweens in relation to the concept of a middle ground we can see that the ongoing changing set of circumstances had its effects on the offered and received knowledge and goods, thereby constantly assessing the validity or quality of the offered goods and knowledge, as is argued in chapter three. Furthermore, these concepts help us to trace how mutable knowledge and goods had to be transformed and stabilized as part of the circulation from one node to the next, as chapter four informs us. Part of the production and consumption of knowledge is the ongoing procedure of stabilizing mutable objects, information, and practices before these transformed immutable mobiles can be circulated to other sites. The transformation and circulation of (embodied) knowledge went hand in hand with the constant flow of collecting, dispersing, mapping, and reworking nature.

This ongoing flow relied on the transformative actions of go-betweens or mediators. These were the men and women who allowed for the accumulation and transportation of knowledge and matter, either embodied in goods and instruments, or mapped and described on paper. They enabled the circulation and accumulation of knowledge along social or trade routes. An intricate combination of mercantile, amateur, learned, artisan, and political practices and networks, operating in gardens, studies, grottoes, polders, and mines, co-constructively produced and consumed knowledge of Dutch public and private gardens, in drained polders and colonies, and on paper as this thesis argues. 


\section{Gardening with mindful hands}

The method used in this dissertation understands gardening (in its broadest sense) as a practical activity, it attempts to perceive how nature was manipulated and contemplated, how and where knowledge and materials were produced and consumed. It uses several analytical models, such as circulation of knowledge and matter, gobetweens, middle ground, conservative invention, and the concept of the mindful hand in order to structure the hybrid history of gardens. The mundane and practical activity of gardening nature stretches out across these models in order to further an understanding of nature. These models strengthen the overall history of knowledge and material production and consumption by tracing the various steps taken by the contemplators and manipulators of nature. The manipulation of nature and the search for the explanation of nature's workings, either philosophically, mathematically, or artistically found common ground in the act of gardening.

To use the concept of the mindful hand as introduced by Lissa Roberts and Simon Schaffer in the volume The Mindful Hand, this dissertation shows that the learned and wealthy elite, as well as manual workers, busied themselves with exposing nature's hidden workings. ${ }^{29}$ These men and women could be found in any rank or station including nobles, professors, patrons, merchants, widows, artisans, amateurs, natural philosophers, gardeners, painters, physicians, surveyors, engineers, poets, millwrights, and architects. Together, they possessed the mental and manual skills to rework nature to reveal its hidden mathematical laws and expose nature's playful artistry, while finding inventive solutions and aesthetic answers to shape their idea of pristine Nature.

Dutch gardens, as historical examples, illustrate the hybrid practices of mind and hand. It is, furthermore, argued here that the concept of the 'mindful hand' collaborates with the concepts of natural inquiry and invention. In these four chapters, we see how inquiry and invention formed a historically intertwined connection that cannot be taken apart into 'theory' or 'idea' as conceived by a learned elite that was then implemented or applied by mindless labourers. Since people from different backgrounds jointly contemplated and manipulated nature, it follows that both inquiry and invention were human activities. However, one group determined that the work of the mind presided over the work of the hand, therefore contributing to an emerging schism, as Christiaan Huygens attempted in chapter two.

Together, these four case studies respond to the histories of science and technology by exposing the joint roots of natural inquiry and inventions in Dutch garden history. This dissertation shows that the hybrid practice of gardening weaved together preconceived notions and practices that were then appropriated to meet local 
ROOTED IN FERTILE SOIL: SEVENTEENTH-CENTURY DUTCH GARDENS AND THE HYBRID HISTORY

OF MATERIAL AND KNOWLEDGE PRODUCTION

requirements, that in turn produced varied adapted inventions and a changed understanding of nature. Since this dissertation uses several analytical concepts - due to the complexity of the overall argument - it draws not only on the literature provided but also on the histories of art and economy, science and technology studies, sociology, and anthropology in order to strengthen the argument that the seventeenthcentury Dutch gardens and the hybrid history of material and knowledge production was rooted in fertile soil. 
1 Taken from the promovendus project description: "Rooted in Fertile Soil: SeventeenthCentury Dutch Gardens, Natural Inquiry and Technology."

2 Peter Dear, Lissa L. Roberts and Simon Schaffer (eds), The Mindful Hand; Inquiry and Invention from the Late Renaissance to Early Industrialisation, (Amsterdam: Edita, 2007).

3 Alette Fleischer, "The Company's Garden and the (Ex)Change Of Nature and Knowledge at Cape Of Good Hope (1652-1700)," Lissa Roberts (ed), Centres and cycles of accumulation: Material and Knowledge production and exchange in and around the Netherlands during the early modern period (forthcoming 2011). Alette Fleischer, "(Ex)Changing Knowledge and Nature at the Cape of Good Hope, circa 1652-1700," Siegfried Huigen and Jan L. de Jong (eds), The Dutch Trading Companies as Knowledge Networks, Intersections; Interdisciplinary Studies in Early Modern Culture, (Brill Publishers, Leiden, 2010) vol. 14, pp. 243-265. Alette Fleischer, "Into the Light: constructors and examiners of nature and a Dutch 17th century garden grotto," History of Technology, 29 (2009), pp. 113-139. Alette Fleischer, "The Beemster Polder: conservative invention and Holland's great pleasure garden," in: Dear, Roberts and Schaffer, The Mindful Hand, pp. 145-166. Alette Fleischer, "The garden behind the dyke: land reclamation and Dutch culture in the 17th century," ICON, journal of the International Committee for the History of Technology, 11 (2005), pp. 16-32.

4 Thomas P. Hughes, "The Evolution of Large Technological Systems," Wiebe E. Bijker, Thomas P. Hughes and Trevor J. Pinch (eds), The social construction of technological systems: new directions in the sociology and history of technology, (Cambridge: MIT Press, 1987), pp. 51-82. Thomas P. Hughes, American Genesis; a Century of invention and technological enthusiasm, 1870-1970, (Chicago/London: The University of Chicago Press, 2004), specifically chapter 2, "Choosing and solving problems," p. $53 \mathrm{ff}$.

5 Richard White, The Middle Ground; Indians, Empires, and Republics in the Great Lakes Region, 1650-1815, (Cambridge/London: Cambridge University Press, 1991).

6 Jan van der Groen, Den Nederlandtsen hovenier, (Amsterdam: Marcus Doornick, 1670). "Inleiding." ... "hier in heeft men, [...] wel zoo veel Heeren Huyzen, Lust-hoven, en Hofsteden [...] de Princelijcke Huyzen en Hoven [...] omtrent Amsterdam [...] d'omleggende Landen van [...] Leyden, 's Gravenhage, Haerlem [...] als oock d'uytgemalen Meeren daer omtrent, en voornamelijck de vette kleygrondige Beemster, Schermer, Purmer, Wormer, \&c. zonder te vergeten de vermakelijcke plaetsen by de stadt Uytrecht, aen de rivier de Vecht gelegen.."

7 Groen, Den Nederlandtsen hovenier, "Inleiding." "Hier in mach Hollandt zich dan geluckig nomen, dat zoo wel alle konsten en wetenschappen, als zeldtzame vreemdigheden, leckernyen, kostelijckheyt, ja schatten en rijckdommen, door den Goddelijcken zegen, overvloedighlijk tot haer in-vloeyen."

8 See for more: John Dixon Hunt, Gardens and the Picturesque, Studies in the History of Landscape Architecture, (Cambridge: MIT Press, 1992), p. 3.

9 Paula Findlen, Possessing Nature: Museum, Collecting, and Scientific Culture in Early Modern Italy, (Berkeley: University of California Press, 1994).

${ }^{10}$ Chandra Mukerji, "Material Practices of Dominion: Christian Humanism, the Built Environment and Techniques of Western Power," Theory and Society, 31 (2002), pp. 1-34. Chandra Mukerji, Territorial ambitions and the gardens of Versailles, (Cambridge: Cambridge University Press, 1997). 
ROOTED IN FERTILE SOIL: SEVENTEENTH-CENTURY DUTCH GARDENS AND THE HYBRID HISTORY

OF MATERIAL AND KNOWLEDGE PRODUCTION

${ }^{11}$ On the hybrid nature of material and knowledge production, see: Lissa Roberts, "Introduction: Transcending Boundaries: Mindful Hands in the History of Technology," History of Technology, 29 (2009), pp. 105-112; Lissa Roberts and Simon Schaffer, "Preface," Dear, Roberts and Schaffer, The Mindful Hand, pp. xiii-xxvii; On the hybrid of nature and art: Lorraine Daston and Katharine Park, Wonders and the Order of Nature 1150-1750, (New York: Zone Books, 1998).

${ }^{12}$ See the critical reviews on the history of science: Peter Dear, "What is the History of Science the History of? Early Modern Roots of the Ideology of Modern Science," Isis, 96 (2005), pp. 390-406; Klaas van Berkel, "De wetenschappelijke revolutie: een nieuwe kans voor een versleten metafoor?," Tijdschrift voor Geschiedenis, 108 (1995), pp. 483-498 and Steven Shapin, The Scientific Revolution, (Chicago: University of Chicago Press, 1996); for an in-depth overview on the historiography of science history see: Cohen, H. Floris, The scientific revolution: a historiographical inquiry, (Chicago: University of Chicago Press, 1994).

${ }^{13}$ Edgar Zilsel, "The social roots of science,” Diederick Raven, Wolfgang Krohn, and Robert S. Cohen (eds), The Social Origins of Modern Science, (Dordrecht: Kluwer Academic Publishers, 2000), pp. 3-6.

${ }^{14}$ Steven Shapin and Simon Schaffer, Leviathan and the air-pump: Hobbes, Boyle, and the experimental life, (Princeton: Princeton University Press, 1989).

${ }^{15}$ Alan G. Gross, Joseph E. Harmon and Michael S. Reidy, "Argument and SeventeenthCentury Science: A Rhetorical Analysis with Sociological Implications," Social Studies of Science, 30 (2000), pp. 371-396; Margaret C. Jacob, The cultural meaning of the scientific revolution, (New York: Alfred A. Knopf, 1988); Robert Mayhew, "Mapping science's imagined community: geography as a Republic of Letters, 1600-1800," British Journal of the History of Science, 38 (2005), pp. 73-92.

${ }^{16}$ Andrew Cunningham and Perry Williams, "De-centering the 'big picture': The Origins of Modern Science and the modern origins of science," British Journal of the History of Science, 26 (1993), pp. 407-432; Andrew Cunningham, "Getting the Game Right: Some plain words on the Identity and Invention of Science," Studies in History and Philosophy of Science, 19 (1988), pp. 365-389.

${ }^{17}$ Harold J. Cook, Matters of Exchange, Commerce, Medicine, and Science in the Dutch Golden Age, (New Haven/London: Yale University Press, 2007); Alix Cooper, Inventing the Indigenous, Local Knowledge and Natural History in Early Modern Europe, (Cambridge/ New York: Cambridge University Press, 2007). See more on indigenous knowledge: Chambers, David Wade and Richard Gillespie, "Locality in the History of Science: Colonial Science, Technoscience, and Indigenous Knowledge,” Osiris, 15 (2000), pp. 221-240; Londa Schiebinger and Claudia Swan (eds) Colonial Botany; Science, Commerce, and Politics in the Early Modern World, (Philadelphia: University of Pennsylvania Press, 2005); Sanjay Subrahmanyam, "Rural Industry and Commercial Agriculture in Late Seventeenth-Century South-Eastern India," Past and Present, 126 (1990), pp. 76-114.

${ }^{18}$ Erik de Jong, Natuur en Kunst, Nederlandse tuin- en landschapsarchitectuur 1650-1740, (Hilversum: Toth, 1995), p. 25. And: Prest, John, The Garden of Eden, the Botanic Garden and the Re-Creation of Paradise, (New Haven/London: Yale University Press, 1988), pp. 87-92. Andrew Cunningham, "The culture of gardens," N. Jardine, J.A. Secord and E.C. Spary (eds), Cultures of natural history, (Cambridge/London: Cambridge University Press, 
2000), pp 38-56; Mara Miller, The Garden as an Art, (Albany: State University of New York Press, 1993); Vanessa Bezemer Sellers, Courtly Gardens in Holland 1600-1650; The House of Orange and the Hortus Batavus, (Amsterdam/Woodbridge: Architectura et Natura, 2001); Christiane Lauterbach, Gärten der Musen und Grazien, Mensch und Natur im niederländischen Humanistengarten 1522-1655, (Munchen/Berlin: Deutscher Kunstverlag, 2004).

${ }^{19}$ Pamela H. Smith, The Body of the Artisan, Art and Experience in the Scientific Revolution, (Chicago: The University of Chicago Press, 2004).

${ }^{20}$ Warren Dym, "Scholars and Miners; Dowsing and the Freiberg Mining Academy," Technology and Culture, 49 (2008), pp. 833-859.

${ }^{21}$ Cook, Matters of Exchange. See also: Pamela Smith and Paula Findlen (eds), Merchants and Marvels: Commerce, Science and Art in Early Modern Europe, (New York/London: Routledge, 2002); Schiebinger and Swan, Colonial Botany.

${ }^{22}$ Bruno Latour, Science in Action; How to follow scientists and engineers through society, (Cambridge: Harvard University Press, 2003); James A. Secord, "Knowledge in Transit," Isis, 95 (2004), pp. 654-672; David N. Livingstone, Putting Science in its Place, Geographies of Scientific Knowledge, (Chicago/London: The University of Chicago Press, 2003); Lissa Roberts, "Situating Science in Global History Local Exchanges and Networks of Circulation," Itinerario, 33 (2009), pp. 1-19; S.J. Harris, "Long-Distance Corporations, Big Sciences, and the Geography of Knowledge," Configurations, 6 (1998), pp. 269-304.

${ }^{23}$ Bruno Latour, Science in Action; How to follow scientists and engineers through society, (Cambridge: Harvard University Press, 2003).

${ }^{24}$ Roberts, "Situating Science in Global History," pp. 1-19.

${ }^{25}$ See for recent literature on go-betweens: Simon Schaffer, Lissa Roberts, Kapil Raj and James Delbourgo (eds), The Brokered World, Go-Betweens and Global Intelligence, 17701820, (Sagamore Beach: Watson Publishing International, 2009); Hans Pols, "European Physicians and Botanists, Indigenous Herbal Medicine in the Dutch East Indies, and Colonial Networks of Mediation," East Asia Science, Technology and Society: an International Journal, 3 (2009), pp. 173-208.

${ }^{26}$ Turnbull discusses go-betweens in relation to boundary crossing in: D. Turnbull, "Boundary-Crossings, Cultural Encounters and Knowledge Spaces in Early Australia," in: Schaffer, Roberts, Raj and Delbourgo (eds), The Brokered World, pp. 387-428.

${ }^{27}$ White, The Middle Ground, p. x.

${ }^{28}$ White, The Middle Ground, p. 52.

${ }^{29}$ See the preface of: Dear, Roberts and Schaffer, The Mindful Hand, pp. xiii-xxvii. 


\section{Chapter one}

\section{The Beemster Polder: conservative invention and Holland's great pleasure garden*}

\section{The Beemster}

The Beemster Lake, seventy-one square kilometers in extent, was the biggest of a series of lakes north of Amsterdam drained in the seventeenth century for land-based development. ${ }^{1}$ The resulting Beemster Polder was constructed between 1608 and 1612. It has since been hailed for many different reasons: as a triumph over water, a statement of Dutch power over nature, a product of technical ingenuity and organizational prowess, a site of agricultural abundance and a repository of architectural and horticultural beauty. The polder came to epitomize Dutch ideas of pristine nature, wholesome and blissful living, just as it symbolized the peace and wealth of the new Dutch Republic. It was celebrated for its pastoral richness, its pleasant country estates and beautifully designed gardens. ${ }^{2}$ The variety of its meanings has attracted a comparable variety of historical accounts. Commentators have remarked on the architecture of the landscape and the country estates. They have lauded the Beemster as a pastoral retreat. Some historians claim that the Beemster was only built once new draining techniques had been developed. Others emphasize the role of individual practitioners such as the millwright Jan Adriaansz Leeghwater, the financier Dirck van Os, or the land surveyors involved in the scheme. ${ }^{3}$

However, the project to build the Beemster Polder was not welcome to all, nor was it at once nor uniformly successful. The labourers whose very livelihood depended on the watery Beemster were not compensated for their losses; they responded by breaching holes in the new drainage dyke and were countered with legal proclamations against their sabotage. Furthermore, the new polder proved initially too wet for arable farming. Most of it was only suitable for grassland, thus for keeping cattle, for milk and meat. The Beemster needed more windmills to pump water, and required ever deeper ditches and canals. Roads had to be raised and finished. Subsidence of the drying earth and maintenance of a sufficiently low water level posed yet further difficulties. It was known from previous drainage schemes that subsidence occurred, but in this case subsidence was insufficiently anticipated. Every winter, 
THE BEEMSTER POLDER: CONSERVATIVE INVENTION AND HOLLAND'S GREAT PLEASURE GARDEN

to the financial despair of stakeholders and farmers, the lowest part of the Beemster flooded anew. Many other fiscal, agricultural and engineering difficulties plagued the programme's success. ${ }^{4}$

Thus to interpret the construction of the Beemster polder as an obviously victorious transformation of nature into culture and a brilliantly successful application of the ingenious devices of the early modern oeconomy of water management, required considerable ingenuity itself. Due to its large scale and size, the venture demanded a different approach from that adopted towards the smaller and shallower lakes that had been drained in the sixteenth century. The drainage led to an exchange of experiences and of custom-based ideas. It provided occasions for the articulation of contemporary and classical notions of Nature, husbandry, water management, urban architecture, mathematics and garden design. This essay argues, therefore, that the creation of the Beemster gave rise to an ongoing and analogous transformation of received ideas and practices in garden aesthetics and economic techniques to fit local circumstances. For reasons that were equally social, economic and technical, the inventions that were adopted tended to be conservative, based on tradition and custom. Historian Thomas P. Hughes first introduced the term "conservative invention," discussing it in several publications. ${ }^{5}$ In his book American Genesis; a Century of invention and technological enthusiasm, 1870-1970, he argues that radical inventions are rejected by private or public organizations fearing financial loss and the de-skilling of "workers, engineers, and managers". The grounds posed to reject the invention are usually labelled as "technically crude and economically risky" thereby in fact "acknowledging the character of the new and radical." Corporations found it safer to choose an invention that was an improvement of the systems of others, thereby coining the phrase: conservative invention, as opposed to the radical invention of independent inventors. This was the case with some inventions proposed by Beemster millwrights that were indeed rejected by the Board of Stake holders. This inventive enterprise paralleled the hermeneutic process through which the Beemster builders gave meaning to their project. Inventive ideas and practices were conservative in the sense that they emerged through the re-investigation of familiar techniques, aesthetics and ideas. 'Conservative invention' may seem an oxymoron; the apparent tension was resolved through the social networks of the Beemster project. While protagonists proved willing to adopt novel theories and techniques, these innovations had to be comprehensible and acceptable to others.

The Beemster was an artificial land that with the help of skill, invention and the arts was turned into 'Holland's great pleasure garden'. ${ }^{6}$ Today the Beemster is often seen as a mere drainage scheme whose only merits are judged functional: farmland and dwelling space. Yet to see the Beemster as a garden as well can help explain how 
THE BEEMSTER POLDER: CONSERVATIVE INVENTION AND HOLLAND'S GREAT PLEASURE GARDEN

it was possible for the early modern Dutch willingly to risk money and resources, adapting and adopting inventions in order to understand, design, rework and husband Nature for pleasure and production.

\section{Wild nature and controlled nature}

In the seventeenth century, according to the historian Clarence Glacken, it was argued that "men must actively interfere with brute nature ... in order to maintain civilization. Nature untouched by man is a lesser nature and the economy of nature is best where man actively superintends it. The role of man as a caretaker of nature, a viceroy, a steward of God....."7 Untamed Nature was associated with the chaos that overcame the Earth after the Fall and the disruption of the harmony that existed between Nature's four elements and three kingdoms. The challenge was to recover this divinely created harmony through the work of oeconomy, to remodel Nature into its prelapsarian state. But God's stewards resorted to more than scriptural precedent to cultivate their land. In this drive to tame brute Nature, they also appealed to written mythological and classical garden typology. Gardeners drew inspiration both from the biblical Garden of Eden and from the classical models of pastoral Arcadia and the Garden of the Hesperides. Increasing numbers of books on garden design and gardening appeared in the seventeenth century as the fashion spread from Italy north to the Low Countries. The merger of these ancient ideals and the application of these principles both in contemporary gardens and writings led to new typological inventions.

These classical notions had to be adapted to Dutch conditions, in light of the local environment and aesthetic sensibilities. Here seemingly abstract and apparently mundane expertise mingled. By combining knowledge of local circumstances with knowledge presented in garden books, a gardener could create a simultaneously flourishing and fashionable site. The social milieu had to provide resources for such ideas. Each horticultural enthusiast might learn from books and from colleagues in order to recreate a private paradise. Natural economy was cultivated by its stewards through experience and gardening, through theory and literary garden typology, and socially in the gardens of others. On the one hand, the garden was rooted in classical soil; on the other, it was adapted to local exigencies. This was how, in all spheres, conservative inventiveness was at work.

The choice of a specific garden iconography depended on the message the owner wished to convey in a horticultural language comprehensible to his peers. The garden, its content and context could be discussed, criticized or admired with these fellows. It was a means of projecting the protagonist's interest in a specialized field and 
simultaneously portraying knowledge and power over Nature. Gardens were also display cases for divine creativity. The ideal was to accumulate every possible specimen of animals, plants and minerals. ${ }^{8}$ Merchants and seamen gathered, stole, hunted, purchased or concocted exotic goods for the European market, to meet the demand for curiosities and wonders of new worlds. So a garden could house sculpture, various exotic plants, topiary, herbs and vegetables, hothouses, fish ponds, fountains, grottoes filled with minerals and galleries of stuffed animals and dried plants. Everything had its place in the garden, thus thematised and controlled.

To this mixture, Dutch culture added an idiosyncratic emphasis on political identity. The Beemster, too, begot a symbolic meaning that lifted this garden to a mythological level, reflecting on the Dutch prowess to create their own country. The young Republic of the United Seven Provinces was often imagined as recreating the ancient "Land of the Batavians," envisioned metaphorically as the Hortus Batavus or "Garden of Holland." With the founding of the Republic, this horticultural typology became a symbol of peace and prosperity. Depictions of the Hortus Batavus show a seated Dutch Maiden, crowned with a spire, in an enclosed garden surrounded by flowers, globes and an orange, the symbol of the ruling House of Orange. The entrance is guarded by the Lion of Holland. In 1644 the poet Joost van den Vondel compared the Beemster with this Dutch Maiden: "Her forehead's spired crown piercing through the clouds: as communal wealth in its noblest sense creates

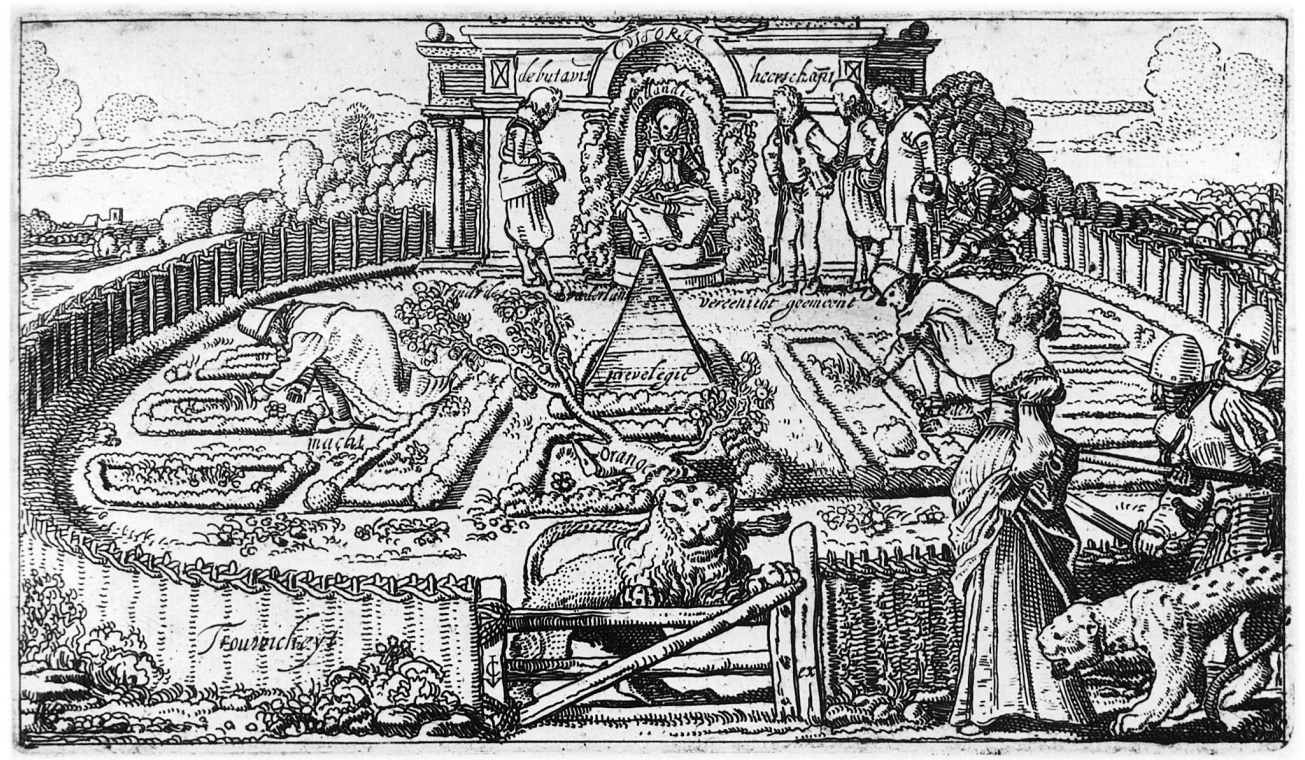

1.1) Willem Buytewech, Allegory on the Twelve Year Truce, 1615, Atlas Van Stolk, Historisch Museum Rotterdam, Rotterdam 
THE BEEMSTER POLDER: CONSERVATIVE INVENTION AND HOLLAND'S GREAT PLEASURE GARDEN

luxury." 10 [see picture 1.1] The Beemster was thus in principle a symbol both of the Hortus Batavus and the Dutch Maiden, and also of the young Republic. Around the polder, a dyke enclosed and protected artificial territory and kept the Dutch safe against their great enemy, water.

\section{First, second and third nature}

It was claimed that untamed nature could be transformed into a new Edenic landscape with the help of art (conste). In seventeenth-century Dutch, the word conste meant more than "art," but also labour, skill and technique. ${ }^{11}$ This semantic scope included practicality and aesthetics in a way that the current definition of art excludes. The engineer Nicolaas de Wit, referring to the drainage of the Pontine Marshes in Italy, used this term conste (ca. 1630) in relation to the reworking of the swamps, that produced "foul smells and housed many evil animals." 12 The marshes ought to be returned to their former beauty, fertility and clean air, so that with God's consent the inhabitants could live in a sound and prosperous environment. Jan van der Groen, gardener to stadholder William of Orange, wrote along similar lines in 1669 that art could make chaotic nature orderly, elegant, pleasant and stylish. He told his readers that nature presented itself in a disorderly fashion, but when aided by the arts, experience, and inventions, it could be transformed into a beautiful garden. ${ }^{13}$ Van der Groen and De Wit used similar terms to characterise the taming of Nature. De Wit used the words conste, arbeijt (labour) and vernuftheit (engineering and intellect), while Van der Groen wrote of consten (arts), ervaringen (experiences) and uitvindingen (inventions). With human skill, invention and cooperation, landscapes and gardens could be made beautiful and fertile.

Van der Groen's important treatise Den Nederlandtsen Hovenier (The Dutch Gardener) was a compendium of earlier horticultural writers' ideas combined with his own experience as a gardener..$^{14}$ It was generally held that wild and chaotic nature could be transformed into an alteram naturam, a Ciceronian cultural landscape with roads, bridges and fields. ${ }^{15}$ This was a managed nature fit for habitation and consumption, opposed to untamed 'first nature'. Within such a scheme, gardens could be considered a 'third nature', nature that was not only husbanded but also aestheticised. The propaganda of the Beemster financiers urged that this lake was an example of brute first nature that had to be cultivated to form a hybrid of second and third nature. It had to be transformed into an oeconomical environment, where profitable husbandry and beautiful gardens fed body and soul.

It was certainly possible to link these enterprises with the visions of Baconianism. ${ }^{16}$ The English courtier and philosopher offered specific remarks on gardens in 
his Essays and Counsels. Bacon stressed the importance of co-operation, since "the People wherewith you Plant, ought to be Gardners, Plough-men, Labourers, Smiths, Carpenters, Joyners, Fisher-men, Fowlers, with some few Apothecaries, Surgeons, Cookes, and Bakers." And he valued advice: "for Great Princes, that for the most Part, taking Advice with Workmen, with no Lesse Cost, set their Things together."17 Bacon urged that the co-ordination of knowledge, labour and skill could change nature into an artfully enhanced environment. This was just what occurred with the Beemster Lake. Garden aesthetics and commercial ideals jointly formed the basis of its outline. The Beemster was not transformed into a new nature simply by changing it into a consumer landscape. It was shaped using geometry and symmetry as its main design principle. The design of this landscape was well planned and organized by the land surveyors and members of the project's board of stakeholders. They reckoned that husbanding wild nature and creating of a hybrid of second and third Nature were one and the same process.

As was common in seventeenth-century architecture, the Beemster's basic design principle was the rectangle. This classical idea undergirded urban, military, and garden architecture. Through the traffic of books and people, fascination with the ideal of regular and symmetrical forms found its way north. In the Low Countries, one of its promoters was the influential mathematician and engineer Simon Stevin, especially in his book Vande oirdeningh der steden (Of the Design of Cities) published around 1600. Appealing to ancient and contemporary precedents, Stevin also advocated straight streets, even-sided building blocks and rectangular or geometricallyordered houses and cities. ${ }^{18}$ Regularity and symmetry provided an antidote against chaos and disorder, and were thus considered the most desirable design principle. Such a principle was also applied to the design of gardens, display cabinets, trellises, flowerbeds and the planting of trees. It indicated order, harmony and surveillance of the owner's property, collections and goods.

An inspection of the Beemster suggests that the surveyors and financiers applied Stevin's ideas. The original lake was cut through with roads and waterways. The land surveyor Jan Pietersz Dou explained that these were laid out in a "commendable order of parallel lines and right angles." ${ }^{19}$ But the overall layout was not a design principle simply copied from Stevin's book. Rather, its grid also allowed easy access by goods and people over land and water. This was a practical issue, since, for example, the trekschuiten (human-towed boats) demanded straight canals. These practicalities had to be taken into consideration, of which surveyors like Dou were well aware. This new land needed to be accessible, consumer-friendly and aesthetic, resulting in a hybrid between the writings of Simon Stevin and the surveyors' experience. 


\section{A community of people}

The urban merchants and regenten who invested heavily in the project judged the drainage of the Beemster Lake a good fiscal prospect. On the whole, a stakeholder was looking for new, lucrative and safe ways to invest money. Until just before the mid-seventeenth century, grain prices were high due to Holland's growing population. From earlier experiences in the drainage of other smaller lakes around Amsterdam, it was known that cereals and oil seeds flourished on the rich clay that lay at lake bottoms. ${ }^{20}$ The wealthy merchant brothers Dirck and Hendrik van Os of Amsterdam were among the first to raise capital. ${ }^{21}$ These two well-educated and wellconnected refugees from Antwerp were co-founders of the VOC, the Dutch East India Company. To spread the risk, the prospective Beemster was divided into parts and sold as stakes. The first sixteen stakes were issued in 1607, eventually increasing in number to around 120 stakeholders. ${ }^{22} \mathrm{~A}$ small group of stakeholders formed a board of overseers, supervised the drainage, hired the workforce and controlled the finances. At first the board were not aware of the implications of the project. They only visited the lake after their enterprise was patented. Thenceforward the board energetically advanced the work, gathering information from farmers on means of closing gaps in waterways and on the situation and methods for dyke construction. ${ }^{23}$ The board also had to confront the interests of those who already drew income from the Beemster Lake, such as local fishermen and the farmers who used rich lake clay as fertiliser. While many unrewarded workmen who found their economic survival in question, responded with violence and were dealt with by proclamation, the board was perfectly willing to pay financial compensation to their fellows on local village councils and cities. ${ }^{24}$

The people responsible for financing the drainage consisted of merchants, civil servants, lawyers and burgomasters. One was a goldsmith. All knew each other directly or indirectly. ${ }^{25}$ This was a social group forged of mutually profitable advantage. The link between money-making and erudition gave nouveaux riches access to a learned establishment. This alliance offered status and access to universities, societies and influential people. Meanwhile, these wealthy tradesmen injected money into their new social circle. Friendship and marriage helped unite these two worlds, as in the marriage of the daughter of Karel Looten, a rich merchant and participant in the Beemster project, to the Leiden theology professor, Karel Heidanus. ${ }^{26}$ The mercantile Looten family could boast not only of their connection with a Leiden professor but counted amongst their acquaintances the poet Joost van den Vondel, eulogist of the Beemster. Professor Heidanus collected Roman antiques, statues and coins. His chamber of antiquities housed various cabinets filled with ethnographica, 
naturalia, weapons, curiosities and prints. ${ }^{27}$ Marital unions such as this linked water flows and knowledge flows. Merchants such as Looten understood the importance of gathering knowledge of goods, shipments, plants, animals, agriculture and any other topic that helped provide for one's livelihood and maintain a certain standard of living. Amsterdam was a marketplace for the exchange of goods, stocks and shares and an important centre for information exchange. Rapid postal delivery, the rise of business newspapers and a tightly knit infrastructure assured that information, like private and business correspondence, reports and prices of shares founded their way to and from the city of Amsterdam. Collecting, distributing and processing facts were vital to maintain the network of local and foreign merchants as well as maintaining other networks. Information on subjects such as botany, simples, instruments, measures, designs, natural history and medicine became more easily available. As with the organisation of the VOC, the Beemster project entailed extensive paperwork, information regarding the lake, patents, lawsuits, minutes, charts, correspondence, decrees, general anouncements flowed in and from the board's office. Collecting data, making decisions, reporting back to the other stakeholders and filing all the paperwork was in fact a mercantile invention that made Amsterdam an important information and commercial exchange. ${ }^{28}$ This information system promoted the distribution of learning, not only in oeconomy and the prices of goods, but also in the field of natural history.

\section{Designing the Beemster}

Since the board financed the project by selling stakes, it was crucial to know the extent of the new territory and how to divide it into evenly sized plots of land. This put pressure on the land surveyors to produce detailed charts as soon as possible. Mapping was the first step in transforming the Beemster's nature. The shape and size of the lake were manipulated by the land surveyors, engineers and financiers. On 21 May 1607 a decree was drawn up by the major project's financiers stating that a commission consisting of four financiers was to support the land surveyor. The decree instructed the surveyor to consider a ring dyke around the lake that was to be placed on the older firm land, incorporating existing water protection systems. This was a contrast with prior dyke systems, in which the dyke would usually be built in the lake, a few meters from the shore, so that there was a natural water reservoir between the dyke and the shore. Furthermore the decree said that the trekvaarten (waterways for towed barges) should be easily accessible and straight, that the surveyor should make suggestions for location of the windmills and for the choice of ditches and waterways to be closed and that he should measure the width and length of the lake. ${ }^{29}$ 
In 1608, after the death of his predecessor, Lucas Sinck became chief surveyor. Sinck was appointed as surveyor to the city of Amsterdam, where he might have met his fellow townsman Dirck van Os. ${ }^{30} \mathrm{~A}$ team of at least five surveyors, all of whom were appointed to the province of Holland, worked on this project. Gerrit Langedijk and Augustijn Bas came from Alkmaar, Reyer Cornelisz from Warmenhuizen, and Jan Pietersz Dou from Leiden. ${ }^{31}$ In January 1611 the nearly empty lake froze solid. The five land surveyors and their assistants measured the lake on the ice using measuring chains to produce a so-called perfecte caerte, the "perfect" map. ${ }^{32}$ This chart provided the basis for the first designs of the projected Beemster Polder. Both in 1611 and in 1612 Sinck and his colleagues produced maps with indications of roads, squares, canals, waterways and the positioning of the windmills. ${ }^{33}$ [see pictures 1.2 and 1.3] They positioned the dyke in such a way that it created the shortest shore

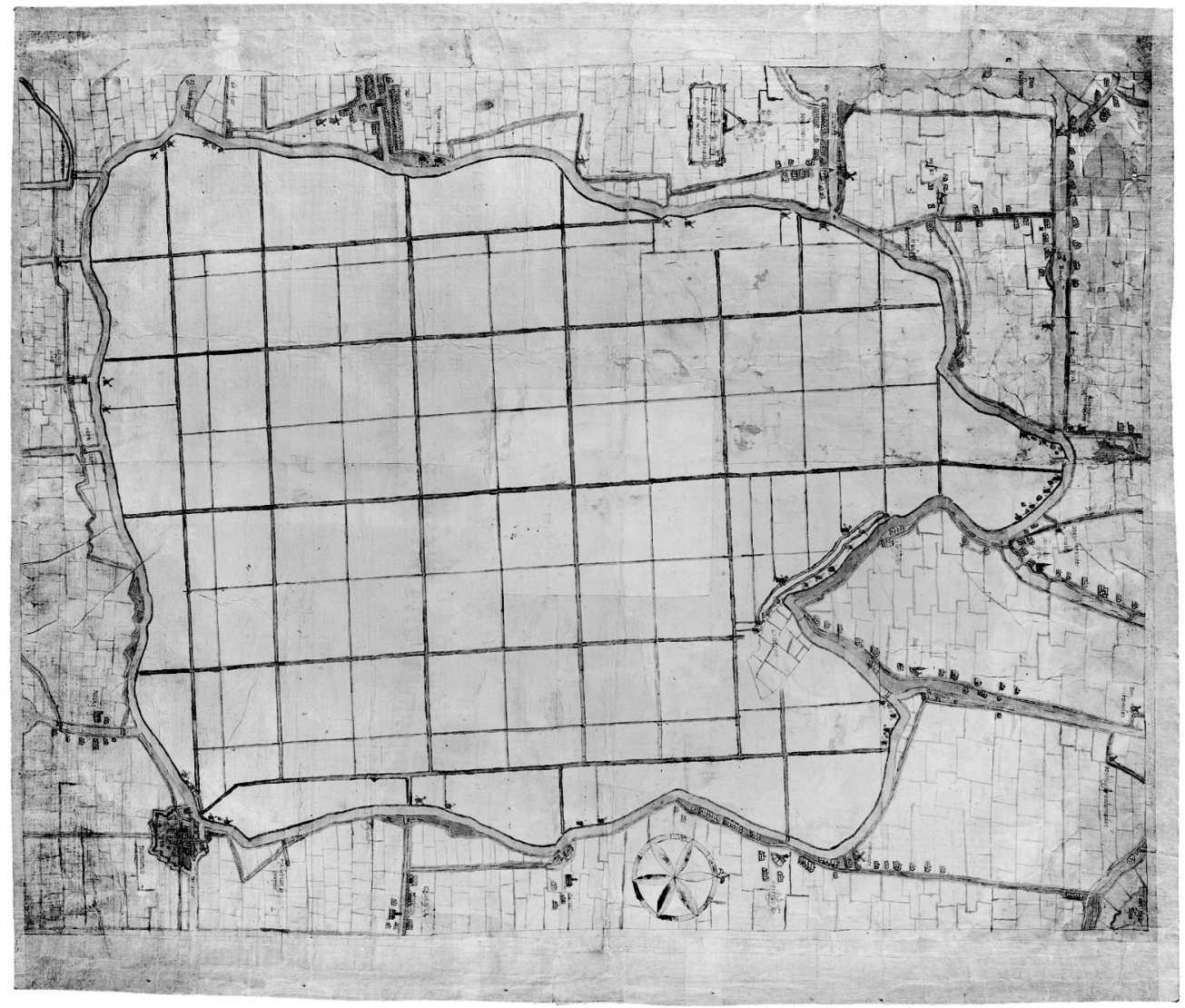

1.2) Anon., draft design of the Beemster, circa 1609, 4-VTH 2600, Nationaal Archief, Den Haag 


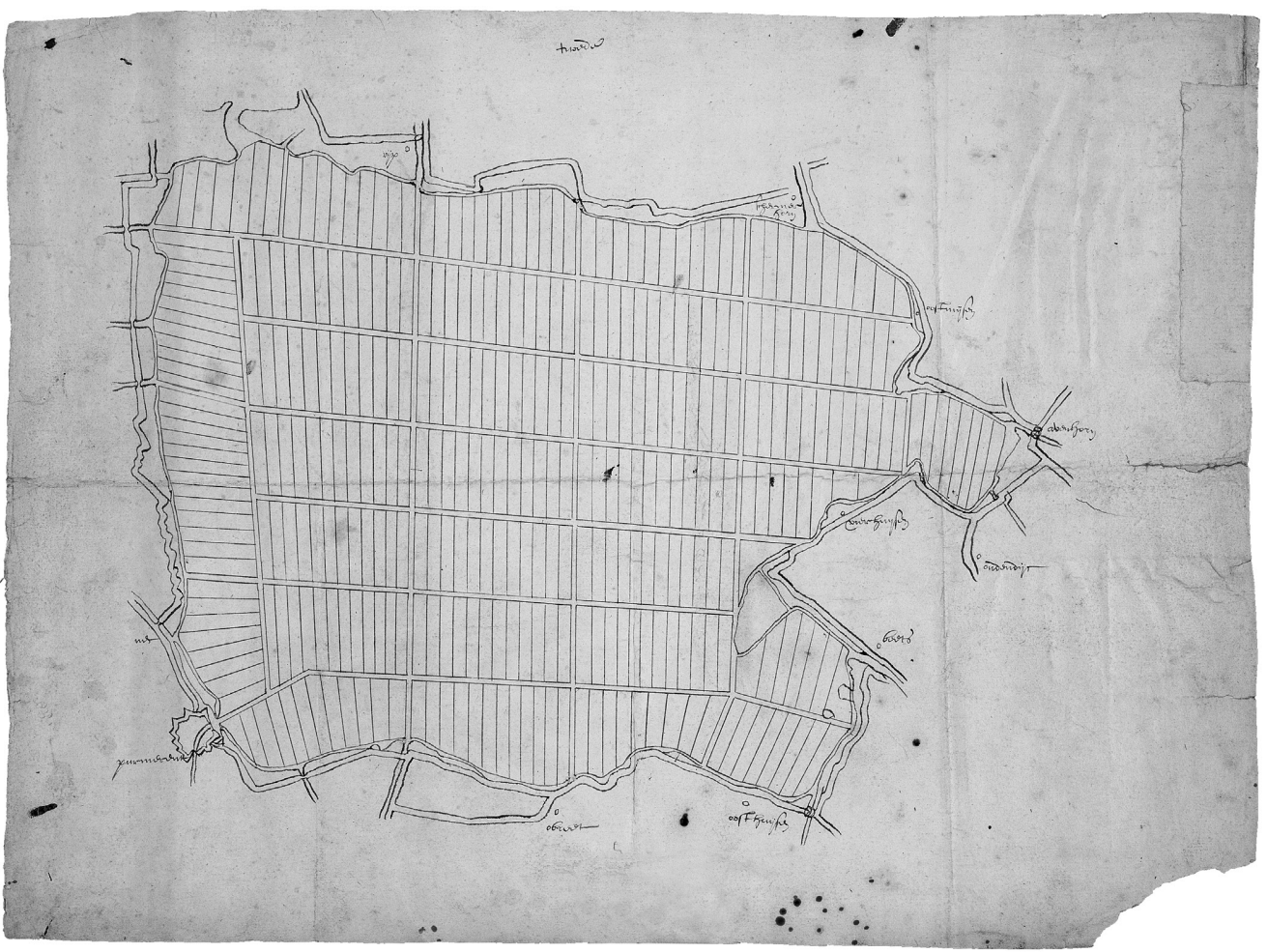

1.3) Anon., draft design of the Beemster, circa 1609, 4-VTH 2599, Nationaal Archief, Den Haag

line. The ring canal behind the dyke was to be more or less straight with as few bends and turns as possible, so that it would be suitable for the towed barges. These considerations, optimising the use of the terrain, made the shape of the Beemster relatively rectangular.

The design, with its uniform roads and waterways, differed greatly from the infrastructure of the older land. With the Board's agreement, the surveyors chose not to connect the Beemster communication system to the existing roads and gave priority to infrastructure within the Beemster. One significant concession was made however, the road connecting the neighbouring town of Purmerend with the Beemster was laid out straight from the main Protestant church into the former lake. This guided the Beemster churchgoers living nearest to the city directly toward the house of God. The Beemster's shape and geometrical pattern gave the polder a design that contrasted clearly with the surrounding landscape. Its symmetry and regularity afforded an optimal use of space and easy access within the Beemster. 


\section{Inventions}

The Beemster drainage project developed in company with the technologies used to pursue it. Technical inventions emerged in this context through the reinvestigation of known and working models. They appeared through the adaptation of existing techniques, objects, ideas and the combination of functions previously embodied in several different instruments. Two examples of such conservative inventions are discussed here: the windmill and milling techniques used for drainage and the introduction of a new surveying instrument.

The Board did not begin with a preconceived notion of which windmill design to choose. Rather mill designers were invited to present their inventions. Though the financiers knew very little about how windmills operated their voice was decisive, since they were funding the project. One condition was clear: a windmill had to be cost-efficient. The Board wanted to work with a minimum number of mills to pump the maximum amount of water in the shortest time. On 10 November 1607 seven mill designers presented their propositions. Each millwright tried to convince the Board that their invention was the best, surest, cheapest or most powerful. Despite claims that a certain invention had worked in Venice or that a certain pump could raise water to a higher level than any known mill, the board decided it was too risky to invest in new types of mills or pumping systems and that testing these models would delay the drainage. The adapted oil mill proposed by Jan Adriaansz Leeghwater was considered, as was the proposal made by Pieter Pieters and Pieter Claasz. These two men suggested using the familiar eight-sided windmill with movable top but with "certain new additions." 34 [see picture 1.4]

Two small prototypes were thus built and investigated by three board members with the aid of mill-masters Jacob Meusz from The Hague and Pieter Jansz from Hoorn. Building models to prove mastery of skill was rather usual among the guilds. A small-scale model was especially required for expensive commissions. The prototype by Claasz and Pietersz proved workable. They were contracted to build ten new windmills and to reuse six good strong older mills. This was common practice since mills were expensive. It involved disassembling a wooden mill, then adapting and rebuilding it where it was needed..$^{35}$ The millwrights advised building all the available mills on the same level. After the water level had sufficiently receded, the positions of the mills would be changed and the water pumped up in two stages, using a water basin between the lower and higher mill. This two-stage milling technique had been patented twenty years earlier by Simon Stevin, but the patent had rather conveniently lapsed before the drainage. It is quite possible that these millwrights were aware of the expiry of Stevin's patent. One part of the lake proved too deep for this two-stage pumping method. ${ }^{36} \mathrm{~A}$ third stage had to be added, placing three mills in a 
THE BEEMSTER POLDER: CONSERVATIVE INVENTION AND HOLLAND'S GREAT PLEASURE GARDEN

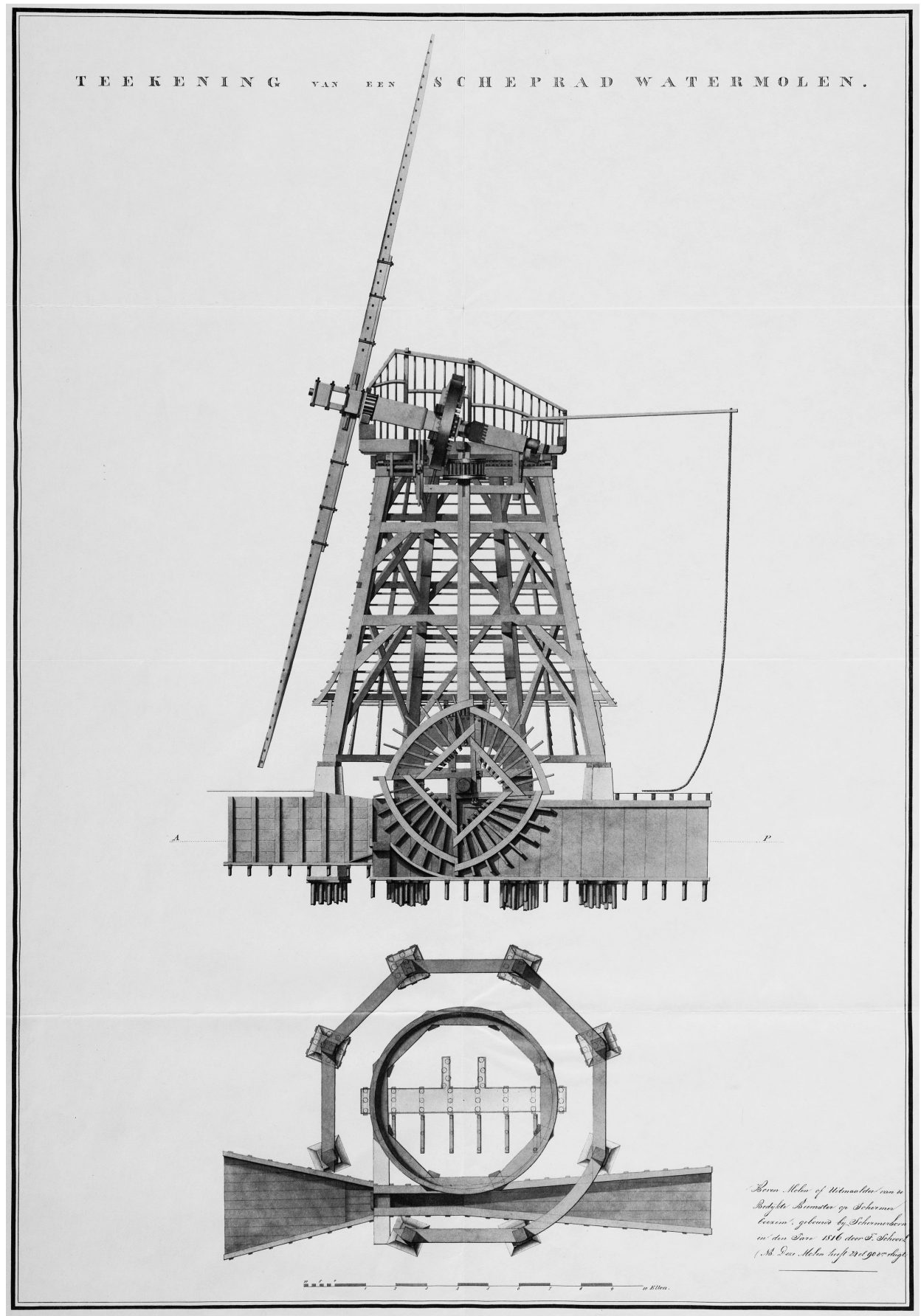

1.4) F. Schoorl, seventeenth-century style windmill, 1816, Waterlandsarchief, Purmerend 


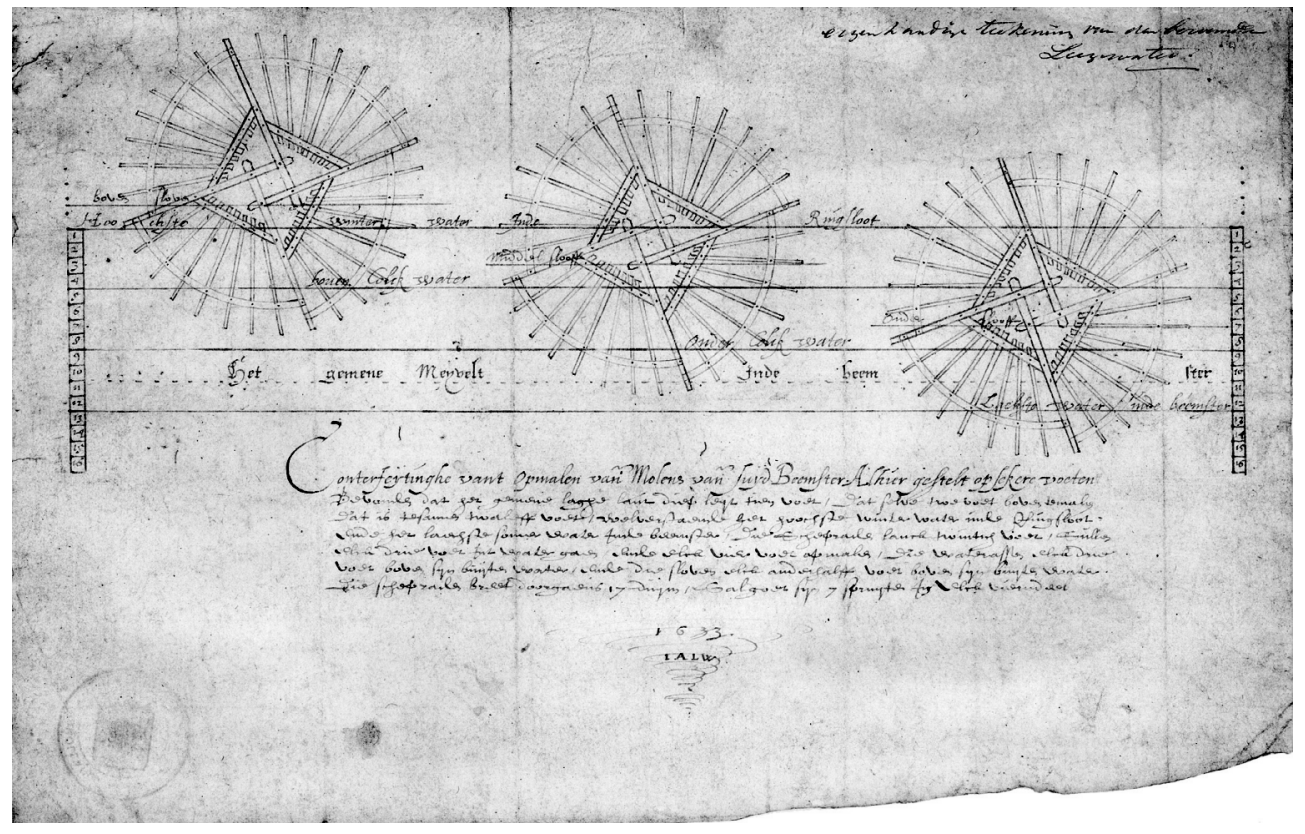

1.5) Jan A. Leeghwater, Three stage milling, 1633, no. 205, Provinciale Atlas Noord-Holland, Haarlem

row with two water basins between them. [see picture 1.5] This meant an increase in the number of windmills to a total of at least forty-three. ${ }^{37}$ Although the millwrights invented three-stage milling, their idea could also have been copied from Stevin's expired patent. At best, their suggestions were an adaptation of a known technological principle already proved workable by Stevin and judged reliable.

The mill technologies used in the Beemster were produced by skilled craftspeople who tried to convince the Board that their invention was cost-efficient and workable. They probably learnt their craft from a master and from working in the province of Holland, elsewhere in the Netherlands and even in Italy. Ignorant of milling, the Board resorted to hiring two advisory mill-masters when the models were shown. Their choice was eventually made on the basis of expected reliability and cost-efficiency. It has been argued persuasively that such devices were then judged on the basis of saving cost rather than labour, since to cut back on work often generated labour unrest. ${ }^{38}$

Another invention that emerged during the project was the introduction of a new surveying instrument by the land surveyor Jan Pietersz Dou of Leiden. In several respects, Dou's career reflected the principles of conservative invention. To become a surveyor one could learn the skill in the field from masters, but after 1600 it was also 
possible to attend Leiden's newly established engineering school and study Duytsche Mathematicque. ${ }^{39}$ This school, linked to Leiden University, taught the techniques of engineering, land surveying, triangulation, geometry and mathematics in Dutch. Dou realized that books in Dutch on these topics were needed. With the surveyor Johan Sems of Friesland he published books on land surveying, Van het gebruyck der geometrijsche instrumenten (On the use of geometrical instruments) and Practijck des landmetens (Praxis of land surveying). These books became standard reading material for surveyors in training. He was also the first to translate the first six books of Euclid in 1605 or 1606 from French and German into the vernacular. ${ }^{40}$ Dou showed that he combined traditional knowledge, such as Euclid's classical geometry, with direct field experience, practical novelty with classical tradition.

For the Beemster project, Dou was assigned to make depth measurements, work on the ring dyke, acquire the land on which the dyke was to be built, and plan and plot the apparently interminable roads and canals in the polder. ${ }^{41}$ While on the job, he introduced a mathematical instrument he had developed to answer his dissatisfaction with existing land surveying instruments. Dou made an instrument that served only the purpose of surveying and would produce fewer errors. ${ }^{42}$ It consisted of a brass circle encasing a cross with a compass at its centre. On the circle were four fixed sights and two moveable sights with small openings. The whole instrument could be fixed on a pole and combined the qualities of several instruments such as the astrolabe and the quadrant. An added virtue was that it could be used for depth measures and double as a surveyor's cross. This new instrument made calculations easier, since Dou also added a goniometric division..$^{43}$ Dou demonstrated the device in the Beemster, where his colleagues took great interest in his equipment. To inform other surveyors of his invention he published a treatise on this instrument in 1612, Tractaet vant maken ende gebruycken eens nieu gheordonneerden mathematischen instrument (Treatise on making and using a newly ordained mathematical instrument), what explained how to make and use this new device. ${ }^{44}$ The so-called Dutch circle or Dou's circle was a great success and was widely used in the Netherlands until the late eighteenth century. Dou's invention also led to a more efficient work method. Residing in Leiden, his erudition and involvement with the new engineering school might well have helped him develop his instrument. Yet Dou devised this apparatus because of his immediate fieldwork. It was not the result of a theory that had to be tested and shown in a university theatre. Dou's Circle was presented in the field to fellow land surveyors as a piece of effective equipment that became thenceforth indispensable to any serious surveyor.

The Beemster drainage did not depend on preexistence of these technologies. Rather, they were produced while working in the Beemster as hybrid results of direct experience and received tradition. In confronting novel predicaments, inventions 
THE BEEMSTER POLDER: CONSERVATIVE INVENTION AND HOLLAND'S GREAT PLEASURE GARDEN

such as three-stage milling and Dou's Circle were designed in situ to overcome costly and time-consuming obstacles. These inventions could not have been conceived other than by the people who got their feet stuck in the Beemster mud.

\section{The four elements and Nature's "true nature"}

It is important to complement this technological account with one that stresses how the very notion of nature itself was at stake in projects like the Beemster drainage. Religious cosmology helped shape such projects as surely as did material and economic interests. Early modern practitioners viewed nature as the work of God. They sought to understand and profit from it accordingly. They wanted to apprehend and recover nature's true nature, the lost prelapsarian world, which led to the creative re-construction of this Edenic garden on a grand scale. But controlling nature and simultaneously controlling the nature of its four elements was a challenge. Using the four classical elements to depict or describe a landscape, garden or site was very common in the seventeenth century. The popularity of Ovid's Metamorphoses was an indispensable resource. In 1586 the philosopher Justus Lipsius published his Laus ruris, praising the four elements for bringing profit and strength: one could feel the four elements so much better in the country than in the city. Lipsius held that in pastoral climes the sun shone brighter, the air was cleaner, clearer and extended further, the water was purer and the earth could show its true form. ${ }^{45}$ In his Traite $d u$ jardinage, selon les raisons de la nature et de l'art (1638) the French royal gardener Jacques Boyceau invoked the need to the four elements in working the land for agriculture and gardening. ${ }^{46}$

The poet Vondel, whose evocation of the Beemster was peculiarly eloquent on questions of elemental cosmology and metaphoric figuration of the polder's meanings, also turned to the four elements in his descriptions of nature, drawing explicitly on Ovid for inspiration. ${ }^{47}$ In his portrayal of the Beemster, Vondel used his vision of the elements to describe their manipulation:

The wind-king, to please the grieving Dutch Maiden,

After all the damages he had caused by storm upon storm,

Moved the mills' wings which, ceaselessly turning, milled

The Beemster into pasture, draining the lake into the sea.

The sun, surprised, saw salty clay, still wet from the waves,

And dried it and gave it an imposing green bodice

Lusciously embroidered with flowers, foliage, fruit and airs

And decorating her hair, sprinkling it with rich scents. ${ }^{48}$ 
The four elements were tamed and made to assist in the polder's construction. Windmills harnessed air to transmute the watery Beemster into earth, which was subsequently dried by the heat of the sun. In order to avoid chaos in nature, Vondel argued, each element needed to be in balance with the others. To achieve this balance, the elements had to be understood.

The cosmology of the four elements provided rich resources for making and making sense of the Beemster project and cognate horticultural enterprises. Earth was reorganised, moved and reshaped, dug out and built up to form dykes, fields, straight ditches and lanes. The territory was surveyed, plotted, exposed from the bottom of the lake and designed into measured plots of land. The surveyor's representation indicated the general layout, giving information on the condition of the terrain, the drainage system and the quality of the different soils. These variables led to a different practice of husbandry within the Beemster. On a smaller scale, the same happened in the preparation and building of the polder's large estates and their formal gardens. There the horticultural amateur worked with the architect, the land surveyor and the gardener to arrange and design a house, outbuildings, gardens and waterworks. The typical estate consisted of a house placed in the centre of symmetrically-designed garden where everything had its place, function and meaning. A central axis divided the garden into two equal halves. On both sides were intricately designed flower beds, clipped box trees and greens. Straight paths lined with trees cut through the garden, leading toward features like rectangular pools, star-shaped forests, statues, fountains and the kitchen gardens and orchards.

Water could be an ally, providing fish and paths for transport, but it was also a severe enemy of the Low Countries. Once constrained by dykes the role of water changed. The lake was pumped up by the windmills and emptied into the circular canal around the Beemster. Excess water had to be disposed of via the canals, but the water that was needed had to be collected and stored in cisterns for irrigation, the fishponds or to maintain the required water-level. Water was also used for playful objects such as hydraulically operated automata, fountains and as a decorative element in shell-covered grottoes.

Air also had a double role in the garden, in the form of wind and the sky. It posed a thread as westerly winds and storms could harm the garden and the house which therefore needed to be protected. To do so, garden owners planted double rows of trees around their houses and grounds. The trees broke the wind and sheltered the garden's more delicate plants and flowers. On the other hand, wind was a resource, used to set windmills in motion, thus helping to drain the Beemster. Wind also distributed the scent of flowers through the air. The sky could be manipulated as well. 
THE BEEMSTER POLDER: CONSERVATIVE INVENTION AND HOLLAND'S GREAT PLEASURE GARDEN

Bushy trees could disclose the sky to the wanderer and give protection against the sun or rain. And as a subtle garden feature the sky could be reflected in so-called mirror pools. With these ingenious techniques, the clouds and the sun were seen simultaneously above and on the level of the ground.

The last element, fire, was essential when it came to keeping and growing precious and delicate exotic plants and seeds. In hothouses, stoves and orangeries the warmth of fire was distributed in such a fashion that each type of plant got the right amount of heat. ${ }^{49}$ The warmth of the sun was also put to good use. In orchards, south-facing serpentine walls provided tender fruit trees with extra warmth and cover against the wind. Special glass lanterns and melon boxes were introduced to grow Mediterranean fruits and flowers. With sunlight and the warmth generated from manure, enough heat could be collected to germinate seeds. Gardeners busied themselves with manipulating the seasons, creating a seemingly endless Edenic spring. Spring that extended the growth and supply of fresh vegetables, fruits and flowers.

Charting the Beemster Lake and the surrounding environment made it possible to understand the lake's nature and change it. Measurement and draughtsmanship demanded more than the mere gaze directed at the landscape; it needed to be examined. The surveyors needed to scrutinize the lake, its terrain, the quality of its shore, to measure its depth and its overall size and shape. Drawing and charting became what has been called a "process of re-creating with our own hand what lies before our eyes" through which one acquired an "understanding of its constituent parts." ${ }^{50}$ But what were these constituent parts? The Beemster's transformation involved more than dividing the terrain into quantitatively defined units. Surveyors' drawings were also the first step in constructing a controlled nature in which the four elements that composed it were brought into productive harmony. Indeed, contemporary wisdom had it that the project actually restored the primal elemental balance lost in the Fall.

The Beemster's nature was thus changed to fit the needs and wishes of the community. With the help of artifice, skill, ingenuity and experience, nature's four elements were changed and reorganized. The elements needed to be reworked and controlled, and by doing so, gave rise to inventions and a new understanding of nature. The Beemster was to be changed from an untidy, chaotic, and dangerous lake into a mythical, prosperous and peaceful Hortus Batavus. To find nature's "true nature," to understand the natural elements of water, earth, fire and air and transform them, was an important aim in the seventeenth century. There too a seemingly inaccessible or inhabitable environment was reshaped through a transformative understanding of its nature into what was considered an improved landscape, where nature's four elements were controlled and harmonized. [see picture 1.6] 
THE BEEMSTER POLDER: CONSERVATIVE INVENTION AND HOLLAND'S GREAT PLEASURE GARDEN

\section{The Beemster: an invention rooted in fertile soil}

Like other seventeenth-century landscapes and gardens, the Beemster was reworked in the image of a profitable and pleasurable environment where nature's elements were manipulated to co-exist in harmony. The investigation and manipulation of the four elements gave rise to inventions of a conservative nature. These inventions were then distributed, adapted, changed and re-used in other forms and ways. By taking lessons from the Book of Nature, combining this with Scripture and the arts, projectors envisaged a well-structured and ordered garden where everything and everyone would know their place. Here was a balanced and harmonic environment that was supposed to recall a pristine past. The Beemster was not only an Edenic landscape, with references to the Judaeo-Christian tradition, but also referred to a classical past. Eden was a model for synthesis of all the natural and mineral ele-

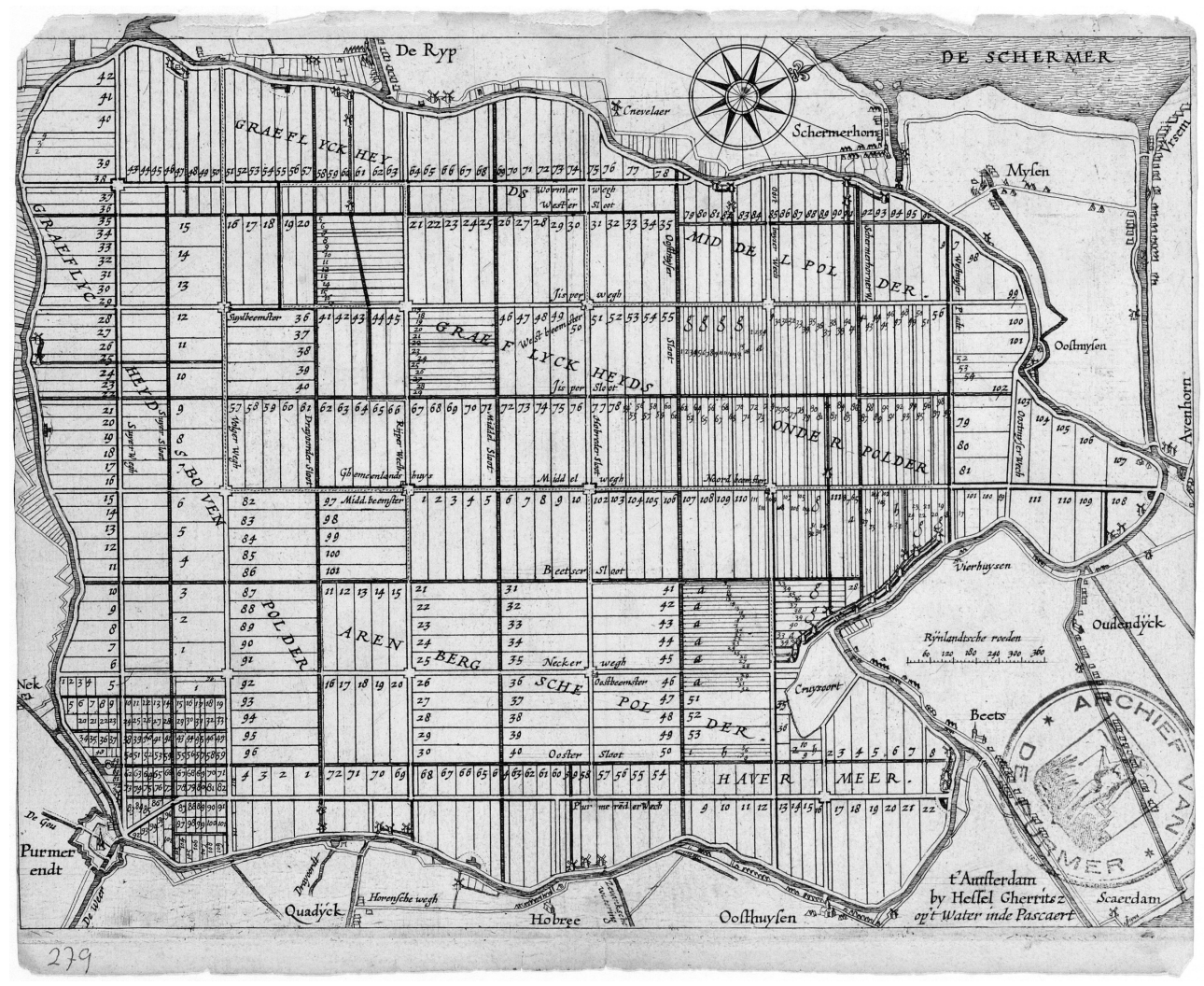

1.6) Hessel Gherritsz, The Beemster, 1612, no. 279, Waterlandsarchief, Purmerend 
THE BEEMSTER POLDER: CONSERVATIVE INVENTION AND HOLLAND'S GREAT PLEASURE GARDEN

ments lost after the Fall. To learn from God's work was for the garden enthusiast a learned pleasure. Invocation of the classical pre-urban Arcadia put emphasis on the pastoral also to be found in the Beemster. ${ }^{51}$ Farming and husbandry provided food for its inhabitants, but in the Beemster garden there was also the element of profit and orderliness. The Hortus Batavus was the typical Dutch garden model. The Dutch Maiden ruled the garden, symbolising the wealth of the Republic and its overseas possessions. Protected by the Lion at the gate, the Dutch were envisioned as labouring in her garden, for profit, for study and for pleasure.

In his poem, Vondel referred not only to the Hortus Batavus and the Dutch Maiden, but also to the Greek goddess Aphrodite. He concluded his poem with the words: "I know, from the foam of the sea this Goddess was born." 52 When he compared the drainage of the Beemster to Aphrodite's birth, he gave expression to the common notion that man had power over nature. This land was born from the foam of the sea and, like Aphrodite, was given the same quality, that of fertility. The rhetoric devoted to the Beemster involved praise of its lush gardens, abundant crop and livestock. Hence emerged the comparison with the fertile goddess. Vondel's comparison also embodied the view that the goddess of the Beemster was not created by another deity but by the Dutch people themselves. They acted like gods when they transmuted water into land. The Dutch were masters over their hard-won Republic and were their own stewards over their land, answerable only to God - the king of kings. The proverb that "God created Earth, but the Dutch created their own country" seemed apt. (Re-)creating a pristine and pastoral landscape was not achieved by one agent but by a community of people. Yet these seventeenth-century makers knew that God had to be thanked and praised for their successes. Without His help, they held, no-one could change nature and learn about His work. According to the doctrines of Dutch Protestantism, knowledge about God was not limited to theologians, preachers or learned men, but achievable by every citizen. All members of the community could participate in this goal and working together on this project was open to everyone. ${ }^{53}$

Like other ways of reworking the landscape, gardening was a collective and inventive venture. This co-operation led to the transformation of their environment by the Dutch on their fellow-citizens' behalf. The Beemster was not the simple culmination of prior inventions and knowledge already achieved. It was, rather, the result of combining received notions with novel experiences in the field, "certain new additions" as one of the Beemster millwrights put it. These conservative inventions, whether technical, theoretical or aesthetic, had to meet social and economical demands. The same set of demands prevented radical innovation. 
THE BEEMSTER POLDER: CONSERVATIVE INVENTION AND HOLLAND'S GREAT PLEASURE GARDEN

\section{Daily life in and with the Beemster}

Yet, however impressive the rhetorical and technical resources invested in its construction, the perfection of the Beemster needed much further work, in drainage, excavation, subsidence and agricultural overhaul, notably the transformation of planned arable into pastoral farming. Thus before the new polder could fully present itself as Holland's greatest pleasure garden and live up to the metaphor of a Dutch Maiden or Aphrodite in an embroidered green bodice, many practitioners had to work hard to change the Beemster's reality and its appearance. The workforce had to plough through the wet clay, measuring the canals, roads and plots, digging canals and ditches, raising the roads and staking out the plots of land. Maintaining the ring dyke was a constant problem. This process continued well into the $1630 \mathrm{~s}$, when the subsidence came to a slow halt. Milling the land sufficiently dry remained a constant battle until 1632, when a few crucial mills were repositioned and five new mills were added, so that the whole of the Beemster was in fact drained with not a three-stage but a four-stage milling technique. ${ }^{54}$ In a resolution of 1 January 1615 the millers were instructed to read their instructions more closely and to act according the ordinance. If they failed to achieve the agreed water level they were either fined or subjected to corporeal punishment. ${ }^{55}$ Another project that took several decades to complete was the planting of trees along side the roads. In the 1612 kavelcondities (lot terms), article 31 stipulated that all roads should be planted with "alder, willow and other trees." The minutes of a meeting held in April 1615 reveal that tree-planting was postponed until the roads were firm. In 1618 all stakeholders were granted the right to plant, at their own expense and maintenance, trees on the roads and dykes bordering their land, but they were allowed to use the wood for profit. In 1682, however, all roadside trees were replaced by the Dutch elms that thrived there until the beginning of the nineteenth century. ${ }^{56}$

The first proper harvest of grain, barley, cole seed and oat that was sown in the spring and early summer of 1612 turned out rather well. Cole seed flourished especially well on the wet clay. But farming remained difficult due to lack of farmers and farmhands, storage and the swampy state of land and roads. People, horses and carts often got stuck knee-deep in the mud. Some of the landowners decided to grow grass and keep cattle, a profitable decision. The Beemster became ever more a green pasture and its main export goods dairy products and meat. ${ }^{57}$ This, in fact, proved to be very profitable since the growing Dutch population could afford to buy meat and dairy products. As cereals were imported cheaply from Danzig and the Baltic region, Dutch farmers changed to more profitable goods like hemp, flax, vegetables, 
and livestock. The economical demand persuaded the farmers to adjust their produce and follow the market. ${ }^{58}$

Landowners' welfare was stimulated by the fact that they received a tax exemption for the first years. The Board explained to the States of Holland that they had to invest so much extra money in maintenance that they did not make any profit at all and therefore should be exempt from tax on consumptive goods and excise on cows and horses. This was granted until $1621 .{ }^{59}$ As the Beemster's earth became more settled, landowners and tenants were able to profit from the land. Some of the higher areas were fit for agriculture. In the lower, wetter areas farmers were able to keep cattle. The Beemster inhabitants started to build their houses, farms, country estates. In the centre, around the planned church square, a village appeared, topped off with a school and church. By the time the Grand Duke Cosimo de' Medici set foot in the Beemster in 1668, it had indeed become a goddess born from the foam of the sea. ${ }^{60}$ The achievement was hard and lengthy. But the representation of the polder as an Edenic recreation pre-dated anything like its realisation. This helps show how the ideological work of horticultural myth-making and conservative precedent played a remarkable role in the natural and social oeconomies of early modern Dutch culture. 
* A slightly different version of this article is published in Lissa Roberts, Simon Schaffer, and Peter Dear (eds), The Mindful Hand: inquiry and invention from the late Renaissance to early industrialization, (Amsterdam: Edita, 2007), pp. 145-166. Another version of this paper is published as "The garden behind the dyke: land reclamation and Dutch culture in the 17th century," ICON, journal of the International Committee for the History of Technology, 11 (2005), pp.16-32. Prior versions of this paper have been presented at SHOT, Amsterdam 7-10 October, 2004, and at the colloquium "Inventive Intersections: Sites, Artifacts and the Rise of Modern Science and Technology,” Amsterdam 22-24 September 2004. I am indebted to Simon Schaffer and Lissa Roberts for their valuable suggestions on earlier versions of this paper, as well as the supporting comments by the participants of both seminars.

1 G.P. van de Ven (ed), Man-made Lowlands, History of water management and land reclamation in the Netherlands, (Utrecht: Stichting Matrijs, 2004), p 161.

2 See the poems by Joost van den Vondel, "De Beemster, voor Karel Looten," Verscheide gedichten, (Amsterdam: Jacob Lescaille, 1644), pp. 342-43, electronically available http://www.dbnl.org/tekst/vond001dewe04/vond001dewe04 0125.htm and A. Wolff, De bedijking van de Beemster (Hoorn: Tjallingius, 1773); the comments of Cosimo de' Medici in: G.J. Hoogewerff, De twee reizen van Cosimo de' Medici Prins van Toscane door de Nederlanden (1667-1669), (Amsterdam: Johannes Müller 1919), p. 272.

3 For instance: Chris Streefkerk, Jan Werner and Frouke Wieringa (eds), Perfect Gemeten, Landmeters in Hollands Noorderkwartier ca. 1550-1700, (Alkmaar: Stichting Uitgeverij Noord-Holland, 1994); Wouter Reh and Clemens Steenbergen (eds), Zee van land. De droogmakerij als architectonisch experiment, (Delft: Technische Universiteit Delft, 1999); Toon Lauwen (ed), Nederland als kunstwerk; Vijf eeuwen bouwen door ingenieurs, (Rotterdam: Nai Uitgevers, 1995); J.G. de Roever, Jan Adriaenszoon Leeghwater, het leven en werk van een zeventiende-eeuws waterbouwkundige, (Amsterdam: Wed. J. Ahrend, 1944); Marc Glaudemans, Amsterdams Arcadia, de ontdekking van het achterland, (Nijmegen: SUN, 2000), p. 132.

4 De Roever, Leeghwater, p. 108

5 Thomas P. Hughes, "The Evolution of Large Technological Systems," Wiebe E. Bijker, Thomas P. Hughes and Trevor J. Pinch (eds), The social construction of technological systems: new directions in the sociology and history of technology, (Cambridge, Mass: MIT Press, 1987), pp. 51-82. Thomas P. Hughes, American Genesis; a Century of invention and technological enthusiasm, 1870-1970, (Chicago/London: The University of Chicago Press, 2004), specifically chapter 2, Choosing and solving problems, p. $53 \mathrm{ff}$.

6 Jan Adriaansz. Leeghwater, Haarlemmermeerboek, (Amsterdam: Pieter Visser, 1724). All translations are mine, unless stated otherwise.

7 Clarence J. Glacken, Traces on the Rhodian Shore, Nature and Culture in Western Thought from Ancient Times to the End of the Eighteenth Century, (Berkeley: University of California Press, 1984), p. 482

8 John Dixon Hunt, "Curiosities to adorn cabinets and gardens," O. Impey and A. MacGregor (eds), The Origins of Museums, the Cabinet of Curiosities in 16th and 17th-century Europe, (Oxford: Clarendon Press, 1985), p. 201.

9 Vanessa Bezemer Sellers, Courtly Gardens in Holland 1600-1650; The House of Orange and the Hortus Batavus, (Amsterdam/Woodbridge: Architectura \& Natura Press, 2001), p. 12.

${ }^{10}$ Vondel, "De Beemster".

${ }^{11}$ Conste means art, artificial, or technical. Vernuftheijt was related to intellect, engineering, 
skill. Woordenboek der Nederlandsche Taal, (Den Haag: SDU, 1993-2001).

${ }^{12}$ J. Korthals Altes, Polderland in Italië; De werkzaamheden der Nederlandsche bedijkers in vroeger eeuwen en het Italiaansche polderland voorheen en thans, (Den Haag: Stockum, 1928) pp. 223-224.

${ }^{13}$ Jan van der Groen, Den Nederlandtsen Hovenier (Amsterdam: Marcus Doornick, 1670).

${ }^{14}$ Bezemer Sellers, Courtly Gardens, p. 181, she argues that Groen drew from French, Flemish and German sources such as J. Vredeman de Vries Hortorum viridariorumque formae, (1583) and D. Loris Le Thrésor des Parterres de l'Univers (1576).

${ }^{15}$ John Dixon Hunt, Gardens and the Picturesque, Studies in the History of Landscape Architecture, (Cambridge: MIT Press, 1992), p. 3.

${ }^{16}$ The work of Francis Bacon was known in early $17^{\text {th }}$ century Holland. The Essays were translated in Dutch; Christiaan Huygens owned a copy of the Dutch version dated 1646.

${ }^{17}$ Francis Bacon, The Essayes of Counsels, Civill and Morall, (Oxford: Clarendon Press, 1985), "Of Plantations XXXIII" and "Of Gardens XLVI".

${ }^{18} \mathrm{Ed}$ Taverne, In 't land van belofte: in de nieue stadt; Ideaal en werkelijkheid van de stadsuitleg in de Republiek 1580-1680, (Maarssen: Gary Schwartz, 1978), pp. 43-45.

${ }^{19}$ H.C. Pouls, De landmeter Jan Pietersz Dou en de Hollandse Cirkel, (Delft: Nederlandse Commissie voor Geodesie, 2004), quoted by Pouls, p. 80.

${ }^{20}$ Van de Ven, Man-made Lowlands, p 165. And: Leeghwater, Haarlemmermeerboek.

${ }^{21}$ Reh and Steenbergen, Zee van land, p. 56. After the Fall of Antwerp, the Van Os brothers moved to Amsterdam.

${ }^{22}$ J. Bouwman, Bedijking, opkomst en bloei van de Beemster, (Purmerend, Schuitemaker, 1857). This book contains most decrees and minutes of the Board of the Beemster, see p. 32.

${ }^{23}$ G.J. Borger, "De Beemster - ideaal of compromis," R.M. van Heeringen, E.H.P. Cordfunke, M.Ilsink and H. Sarfatij (eds), Geordend Landschap, 3000 jaar ruimtelijke ordening in Nederland, (Hilversum: Verloren 2004), pp. 75-102.

${ }^{24}$ De Roever, Leeghwater, p. 93-9.

${ }^{25}$ Helga Danner, Van water tot land, van land tot water; verwikkelingen bij de indijking van de Beemster, (Wormerveer: Kunstdrukkerij Mercurius, 1987), p. 9 and onwards.

${ }^{26}$ Willem Otterspeer, Groepsportret met Dame I; Het bolwerk van de vrijheid; de Leidse universiteit 1575-1672, (Amsterdam: Bert Bakker, 2000), p. 76 and pp. 304-5. And Johan E. Elias, De vroedschap van Amsterdam, 1578-1795, (Haarlem: Loosjes, 1903-1905), p. 197.

${ }^{27}$ Ellinoor Bergvelt and Renee Kistemaker (eds), De wereld binnen handbereik, Nederlandse kunst- en rariteitenverzamelingen, 1585-1735, (Zwolle: Waanders, 1992) p. 80

${ }^{28}$ Woodruff D. Smith, "The Function of Commercial Centers in the Modernization of European Capitalism: Amsterdam as an Information Exchange in the Seventeenth Century," The Journal of Economic History, 44 (1984), pp. 985-1005.

${ }^{29}$ Bouwman, Bedijking, p. 44-45

${ }^{30}$ Ibid., p. 110-112, meeting of 29 March 1610.

${ }^{31}$ A.J. Kölker, G.H. Keunen and D. de Vries (eds), De Beemster, (Alphen aan de Rijn: Canaletto, 1985), with reprints of most of the Beemster maps.

${ }^{32}$ Erik de Jong, C. Steenbergen and P. de Zeeuw, "De Beemster. Een arena van natuur, kunst en techniek," in Lauwen, Nederland als Kunstwerk, p. 157. This map is lost.

${ }^{33}$ Ibid., p 158-159.

${ }^{34}$ Bouwman, Bedijking, p. 58-59.

${ }^{35}$ Ibid., p. 59-60. 
${ }^{36}$ De Jong, Steenbergen and De Zeeuw, "De Beemster," the idea of placing mills in rows of two's came from the mathematician and engineer Simon Stevin.

${ }^{37}$ The drainage started with sixteen mills, but by 1608 there were twenty-one mills, in 1609 twenty-six, and in 1612 the total was forty-three mills.

${ }^{38}$ S.R. Epstein, "Craft Guilds, Apprenticeship, and Technological Change in Preindustrial Europe," The Journal of Economic History, 58 (1998), pp. 684-713.

${ }^{39}$ P.J. van Winter, Hoger beroepsonderwijs avant-la-lettre. Bemoeiingen met de vorming van landmeters en ingenieurs bij de Nederlandse universiteiten van de $17^{e}$ en $18^{e}$ eeuw, Series: Verhandelingen der Koninklijke Nederlandse Akademie van Wetenschappen, afd. Letterkunde, (Amsterdam/Oxford/New York, Noord-Hollandsche Uitgevers Maatschappij, 1988), vol. 137, pp. 5-148 for further reading.

${ }^{40}$ Pouls, De landmeter, p. 21.

${ }^{41}$ Ibid., p. 22.

${ }^{42}$ Ibid., in the $19^{\text {th }}$ century it was named the Hollandse cirkel (Dutch circle), but Dou just called it a mathematical instrument.

${ }^{43}$ Ibid., p. 84

${ }^{44}$ Taverne, In 't land van belofte, p. 80.

${ }^{45}$ Christiane Lauterbach, Gärten der Musen und Grazien, Mensch und Natur im niederländischen Humanistengarten 1522-1655, (Berlin/München: Deutscher Kunstverlag, 2004), pp. 90-91.

${ }^{46}$ Jacques Boyceau, Traité du jardinage, selon les raisons de la nature et de l'art, (Nördlingen: Verlag Dr. Alfons Uhl, 1997), p. 1 and 4.

${ }^{47}$ Arie Jan Gelderblom, Mannen en maagden in Hollands tuin; Interpretatieve studies van Nederlandse letterkunde 1575-1781, (Utrecht: Rijksuniversiteit Utrecht, 1991), pp. 63-77. "Fire gets its place in the sky, in the shape of the stars, under the sky is air, the place where birds fly, then there is earth with on it the animals, and around the earth is water, filled with fish."

${ }^{48}$ Vondel, "De Beemster."

${ }^{49}$ Chandra Mukerji, "Storehouses to Stoves: Built Environments and the Early Dutch Plant Trade," a paper presented at the symposium Dutch Culture in the Golden Age, University of Pennsylvania, Philadelphia, April 1999

${ }^{50}$ Alain de Botton, The Art of Travel, (London: Penguin, 2002), p. 222. He refers to the $19^{\text {th }}$ century painter John Ruskin but it is also approriate for the seventeenth century artist.

${ }^{51}$ Glaudemans, Amsterdams Arcadia, p. 142

${ }^{52}$ Vondel, "De Beemster."

${ }^{53}$ Harold Cook, "The new philosophy in the Low Countries," R. Porter and M. Teich (eds), The Renaissance in National Context, (Cambridge: Cambridge University Press, 1992), p. 137

${ }^{54}$ Bouwman, Bedijking, Borger Geordend landschap, p. 94

${ }^{55}$ Waterlandsarchief Purmerend: Archive Beemster Polder, book 3 page 41, resolutions.

${ }^{56}$ On the planting of trees: Bouwman, Bedijking, pp. 134, 157, 163, 223; the complete list of articles of the statements on pages 286-299.

${ }^{57}$ Ibid., pp. 141-13, 145-6, 175.

${ }^{58}$ Jan de Vries and Ad van der Woude, Nederland 1500-1815, De eerste ronde van moderne economische groei, (Amsterdam: Balans, 2005), p. 241

${ }^{59}$ De Roever, Leeghwater, pp. 112-113.

${ }^{60}$ Hoogewerff, De twee reizen van Cosimo de' Medici, p. 272. 


\section{Chapter two}

\section{Into the light: crystals and the recreation of nature in seventeenth-century garden caves and cabinets.*}

\section{Introduction}

Mylord Bentings...delicate Gardens, Walks, Ponds, Motes, Grottoes, Fountaines and figures, Bridges and Gates and great Plenty of fruit and flowers very Curious and various; A place so neatly composed that here Art and Nature seem to go "hand in hand". 1

Thomas Penson, 1690

There are many bodies, vegetable, mineral, and congealed salts, which are formed with fixed angles and regular forms. [...] All these things are worthy of being carefully investigated to ascertain how and by what artifice nature there operates. $^{2}$

Christiaan Huygens, 1690

In the same year, the English gentleman Thomas Penson and the Dutch mathematician Christiaan Huygens commented in their writings on the relation between art and nature. Penson admired the garden of Hans Willem Bentinck's estate Zorgvliet (Flight from Care) near The Hague for the way art ordered nature and the welldesigned composition of the different artificial and natural elements. Zorgvliet was a fine example of how the mundane act of gardening entailed combining aesthetics and engineering techniques to restore the ordered splendour of pre-lapsarian nature. Like other contemporary garden designers, Bentinck and his constructors sought to make manifest the dominion of nature's laws which God had hidden from sinful humans. ${ }^{3}$ A garden thus became a representation of or a clever allusion to divine design, where its layout manifested mathematical rules and its movements were mechanical. Imposed by garden constructors, art rendered nature more 'natural' ${ }^{4}$

Christiaan Huygens' remark records his enthralment with the beauty of nature's hidden order, which he found lodged in plants, minerals, and salts. He declared artifice to be the designer of nature. In this case, art was not a human activity but a 
INTO THE LIGHT: CRYSTALS AND THE RECREATION OF NATURE IN SEVENTEENTH-CENTURY GARDEN CAVES AND CABINETS.

grand design that sprang from God. Huygens sought to reveal nature's laws by using mathematical rules and the vision of a mechanically operating nature. While he experimented with natural elements and processes to expose these divinely imposed rules, Penson experienced the garden as a site where human art applied rules and augmented nature in order to recover the beauty and order of God's original design. Mr. Bentinck, his garden constructors, and Huygens manipulated and contemplated nature for reasons that were both enlightening and entertaining, in order to reveal or recreate nature's working. This essay focuses particularly on one specimen of nature to illustrate how both constructors and examiners of nature sought to compose a compelling expression of nature's orderliness: rock crystal.

Unearthed as a by-product from a mine in Germany, rock crystal entered both Bentinck's garden and Huygens' cabinet. Various groups of collaborating actors simultaneously transformed rock crystal into an object of adornment and an object of revelation. The outcomes in which this process played a part were Bentinck's Grotto of Ganymede and Huygens' Traité de la Lumière. This paper discusses how different groups of people manually and mentally appreciated the embodied qualities of the crystal and for different reasons, in order to reveal what they took to be the crystal's 'true' nature. The crystal was an ingredient of the reconstruction of nature in a garden grotto, where its refractive nature formed part of a cunning spectacle with light. At virtually the same time, it led to the re-presentation of nature in a natural philosophical treatise on light, where its refractive nature was explored to reveal the law that governed it.

The rock crystal brought together a network of people from various backgrounds and with different skills and talents. There was the nobleman and diplomat Hans Willem Bentinck, the gentleman Constantijn Huygens who was secretary to the Dutch Stadholder William of Orange, Constantijn's younger brother the mathematician Christiaan Huygens, the silk merchant Philips de Flines, Prince Johan Maurits of Nassau, and various anonymous engineers, miners and garden constructors. The way this circle interacted and exchanged information, ideas, and objects was essential to both material and knowledge production. Importantly, this entailed a history of collaboration rather than one of distinction in which theory held sway over manual labour and mindless tinkering.

Although noblemen, mathematicians, merchants, miners, and others mundanely interacted and collaborated, potent social and cultural conventions prevailed to distinguish groups from each other. The nobleman Christiaan Huygens, for example, donned the label geometre to set himself, as a gentleman scholar, apart from those who practiced mathematics in the field, such as engineers. ${ }^{5}$ Elites socially and culturally stood above manual work, keeping labourers at bay. But actual practice of- 
INTO THE LIGHT: CRYSTALS AND THE RECREATION OF NATURE IN SEVENTEENTH-CENTURY GARDEN CAVES AND CABINETS.

ten revealed a different pattern of interaction. Huygens depended as much on his extended network of patrons, merchants, miners, and family as on his connections with Newton and other geometers. Objects and ideas circulated within this network, whereby they were transformed into elements of natural inquiry and invention. One outcome of this transformation was a hugely important treatise on the nature of light; another was a much appreciated garden grotto.

Historians of science such as Alan Shapiro have chosen to focus their work mainly on Huygens' relationship with other scholars while discussing the generation of his treatise on light and the 'internal' development of his optics. But to do so, leaves out the larger theatre of his collaborations and interactions. ${ }^{6}$ The history presented here is not one of the great hero-scientists Descartes-Huygens-Newton or of the construction of a theory that informed the work and understanding of amateurs and artisans. Rather, it sets out to show that the construction of Traite de la Lumière was a collaborative effort. Huygens' knowing and doing as well as that of the other members of this broad network together provided the formative components of this inventive treatise.

This paper, thus, places Huygens' inquiry into light and refraction in a different light. It connects the construction of a grotto and a treatise, thereby stressing how examining and recreating nature were two sides of the same coin. Following the journey of rock crystal from the dark recesses of the earth into the limelight reveals how this circulation and interaction led to the construction of garden grotto and a treatise on light. As it passed through the mindful hands and handy minds of constructors and examiners of nature, the crystal's path traced the contours of the ways in which members of this diverse network simultaneously adapted and displayed their apprehension of the orderly beauty and workings of nature.

Creating a garden grotto involved the transformation and embellishment of natural elements into an artful nature. Garden owners and their gardeners restructured nature by contemplating and manipulating the rules of geometry, jointly engaging their hands and minds as they structured the landscape and populated it with plant beds, orangeries, statuary and fountains. In a garden grotto, more specifically, they manipulated and contemplated the movement of light in order to create optical trickery. Natural philosophers jointly engaged their hands and minds to investigate nature in their cabinets by examining specimens with instruments and working with pen on paper, in order to understand the rules that order nature's operations. Restructuring and investigating nature were mutually reinforcing ways of producing embodied natural knowledge, whether in the form of a garden grotto or a book.

In order for nature to be transformed into an intriguing ornament or an object of inquiry, its elements and/or processes had to be removed from their natural sur- 
INTO THE LIGHT: CRYSTALS AND THE RECREATION OF NATURE IN SEVENTEENTH-CENTURY GARDEN CAVES AND CABINETS.

roundings. ${ }^{7}$ In their original habitat, elements of nature remained invisible in a way; untouched by art or contemplation, nature hid its secrets from prying humans. Once removed and transported to a garden grotto or a study, that humans could investigate, transform, and exchange naturalia. ${ }^{8}$ Both sites can be considered as laboratories where invention teamed with natural inquiry in order to domesticate nature. In these laboratories the reconstruction of nature, the recording of ideas and an exchange of information took place. The objects and elements themselves or the information about them found their way - permanently or temporarily - into other gardens, grottoes, and workrooms, where they were further manipulated and contemplated.

To map out the complex transformative journey of the crystal, this paper starts at the site from which the rock crystal was extracted: a mine in the county of Lingen (today's Germany). Then we follow its trail to the Grotto of Ganymede in Bentinck's garden just outside The Hague, and further to the quarters of Christiaan Huygens in the Bibliotheque Royale in Paris. The concluding section links these last two locations where mental and manual labour created objects of revelation in order to explain the workings of nature.

\section{The belly of the earth}

Passing through Lingen, on the way to Celle, I was shown large pieces that were half earth and half rock, upon which a number of points grow that resemble and have the same hexagonal shape as rock crystal. I take these points to be about a half inch [pouce] in diameter, but the Magistrate of Lingen told me that larger ones have been found, which could be cut into seals and other things. They are so little valued there that he told me that he had sent very large pieces from this mine to Mr. Benting, solely to decorate the fountains being built at Sorgvliet.

Constantijn Huygens to Christiaan, 3 October $1680 .^{9}$

In the autumn of 1680, Constantijn Huygens accompanied the Dutch Stadholder Prince William III, as secretary, on a political mission. One of the stopovers was the city of Lingen in the county of Lingen. This area was a protectorate of William III, who appointed his courtier and diplomat Hans Bentinck as sheriff of Lingen in 1675. Huygens witnessed that the magistrate of Lingen, Mr. Tollius, had shipped a whole load of large pieces of crystal to Bentinck in The Hague as ornaments for his garden. The political connotation of this gift underlined the patronage of William III to the County of Lingen, since this industrious mining area was under his protection and managed by Tollius and Bentinck. 
INTO THE LIGHT: CRYSTALS AND THE RECREATION OF NATURE IN SEVENTEENTH-CENTURY GARDEN CAVES AND CABINETS.

Constantijn seemed surprised that the people of Lingen valued the crystals so little, that they would give them away as mere ornaments. He calculated that these hexagonally shaped rocks would certainly be valuable to his brother's inquiry into nature. The Lingen miners, so it appeared to Huygens, did not realize that this crystal contained knowledge of nature. Huygens, however, did not understand that for the mine workers the crystals did signify something. For them, the gifting of rock crystal expressed a political message whereas bits of rock crystal, polished into little ornaments, bore a symbolic meaning.

Seen from a commercial standpoint it made sense to say that the locals considered the pieces with small crystal points of little value. They used only the bigger pieces of crystal to carve and polish marketable ornaments such as seals. The Lingen craftsman transformed elements of nature into art objects, a process that entailed a certain knowledge of nature. ${ }^{10}$ Carved with images of saints, biblical figures or of miners' tools, these ornaments became precious talismans. ${ }^{11}$ This gave an added and divine meaning to the crystals, which the Lingen miners understood as a way to protect them while doing their dangerous work.

There were three mines in the county of Lingen: a limestone quarry close to the village of Rheine and, in nearby Ibbenbüren, a stone quarry and coalmine. ${ }^{12}$ The still active coalmine is known today as a site where the type of rock crystal described by Constantijn Huygens might be found. ${ }^{13}$ The excavated rock crystal was a by-product from one of these mines. Constantijn told his brother four years later that the crystal "grew in a grotto" deep in a mountain. ${ }^{14}$ This 'grotto', tucked well into the earth, did not at all resemble Bentinck's idyllic and well-designed garden grotto that would become the rock crystal's new environment. The dark quarry was an inhospitable, irregular and eerie place. ${ }^{15}$ It "lacked symmetry and proportion," if we follow the view of André Félibien, who also described the Grotto of Thétis in Versailles. ${ }^{16} \mathrm{He}$ regarded caves as the natural bowels of the earth, where the mysterious growth of rocks and plants occurred. ${ }^{17}$ In his description he opposed natural caves with artificial garden grottoes. The latter exposed and resolved the mystery of a natural cave through their symmetry and proportion, order and variety. ${ }^{18}$

In mines, nature's dark secrets were only visible to the miners. With their tools and torches, they extracted the crystals from the earth, thus making the first step in the crystal's transformation from an undisclosed 'invisible' part of the earth's interior to an object of contemplation and manipulation. Working in a hostile environment the mine workers relied on their accumulated knowledge of the earth's textures, to find their precious ores and minerals, while keeping an eye out for their own safety. This involved close teamwork and a sharing of skills and knowledge, a combination of on-site experience and years of manual and mental understanding. ${ }^{19}$ 
This hierarchically organized skilful workforce knew what to do and how to do it, thereby passing their accumulated wisdom on to younger generations. ${ }^{20}$

The art of mining was a complex activity, which entailed amassing knowledge of the mine area through calculation, experience and experiment. Before anything else, the miners - usually those with surveying experience - had to gain information regarding the whereabouts of the deposits of the natural riches. They used surveying instruments both on and below the earth's surface to measure the borders and determine the depth of the mine; investigated the composition of the earth's layers before constructing vents and shafts; took steps to control the water level inside the mine; established the routes and method of transportation of people, tools, and goods in both vertical and horizontal direction and, finally, obtained the various mining equipment they would need to retrieve the coal, rocks, and rubble from dark mine shafts and galleries.

The examination of minerals and other unearthed rocks and stones took place above ground. ${ }^{21}$ Below the earth's surface, invisible to all except the miners, the mine was constructed according to a pattern of vertical shafts and horizontal galleries. The miners transformed the belly of the earth into a geometrical environment in order to free its hidden treasures using their tools, carts, baskets, ropes, candles, geometrical devises and their accumulated knowledge of the terrain. While reshaping the earth into an organized and accessible underworld, they obtained an understanding of nature's construction. These miners retrieved the once hidden minerals for the world above ground by imposing order upon nature. ${ }^{22}$

During the final stages of the mining process, the miners separated the coal from the rubble, thereby distinguishing the rocks with minerals from those without. The coal fuelled the local lime-kilns, which was Lingen's main economic pillar. The rocks containing large crystals also formed a source of income for the miners, since the local craftsmen transformed the large crystals into ornaments to be sold as talisman. For the Lingen inhabitants the rocks with the small crystal points served to pay tribute to the first visit of an Orange Stadholder and to Bentinck, Lingen's far-flung sheriff. The miners' manipulation of nature in order to reveal its hidden secrets was thus motivated by a combination of mundane economical and political reasons, for the Lingen people hoped that with this gift the Stadholder and the sheriff would in return ease the taxes and allow them to remain Roman Catholic. ${ }^{23}$.

Returning to Constantijn's remark that the people of Lingen valued the rock crystal insufficiently, we can say instead that they valued the rock crystal differently. They appreciated it for its use to express a political union with the Dutch Republic. Constantijn may have found the workers an ignorant lot because they did not consider the crystals as a potentially valuable step toward the examination of light and 
INTO THE LIGHT: CRYSTALS AND THE RECREATION OF NATURE IN SEVENTEENTH-CENTURY GARDEN CAVES AND CABINETS.

refraction. However, without the miners' ways of knowing and doing, their skilful knowledge of nature, the crystals would not be 'freed'. Finally out in the open, the rock crystal could continue its journey of transformation.

Having arrived in a fully manmade environment, crystals were domesticated by nature's examiners and constructors, transformed into objects of study, appreciation, delight and wonder. In the grotto, crystals reminded constructors and observers of the fertile mysteries occurring in the earth's bowels. In the study, crystals prompted examiners to reveal nature's hidden laws. From their perspective, nature's beautiful order remained unexplained in 'the wild', but could be further transformed, contemplated, examined, explained, and manipulated in these 'laboratories'. Previously unseen, the crystal's exposure in these controlled environments clarified nature's laws in various ways. Aesthetically replaced in a grotto, this new vision of nature's variety and unity could be projected back out to make sense of the world at large. ${ }^{24}$

By the end of 1680, the shipload of crystals arrived at Zorgvliet. The constructors began to alter these stones into grotto ornaments. For this they used their artful knowledge and skill, thereby adapting grotto-building conventions to fit local requirements. Ensconced in Bentinck's grotto, the crystal's meaning transformed to symbolically reveal the earth's secrets and emphasize the political bond between Bentinck and the Stadholder. Ganymede, as the cupbearer of the gods, pointed to Bentinck's position as servant to the Prince of Orange. The Grotto of Ganymede became a complex construction filled with natural and artificial objects for reasons that were both entertaining and enlightening.

Some two to three years after Constantijn Huygens left Lingen, pieces of the rock crystals arrived in his brother's cabinet, where Christiaan examined them as part of his inquiry into the nature of light. ${ }^{25}$ From 1672 to 1690 Huygens tinkered with both Iceland and rock crystals in his quest to uncover nature's laws and explain the nature of light. With art and reflection he transformed his crystals so that they would reveal their secrets. This entailed a process of manipulating and contemplating different types of crystal. His findings were made public to the world through his treatise on light, the Traité de la Lumière of $1690 .{ }^{26}$ But before turning to Christiaan's handling of crystals and light, we trace the crystal's adaptation from an unadorned rock into a stunning ornament in the garden of Bentinck.

\section{The Grotto of Ganymede}

From 1674, when Bentinck became the owner of Zorgvliet, he began a huge overhaul of the existing garden by redesigning and enlarging it to almost triple its original size. Its new overall layout consisted of various rectangular sections filled with in- 
tricately designed parterres, a labyrinth with an artificial mount, a pyramidal shaped mount, two grottoes, a large orangery, various kitchen gardens and orchards, an aviary and fishponds. The garden housed a wealth of plants and objects from both northern and southern garden traditions adapted to fit local requirements. [see picture 2.1]

The construction of the Grotto of Ganymede started in 1679 and was probably finished in 1681 . To reach it, one walked from the house passing the semicircular conservatory and an enclosed orchard filled with fruit trees. Then, at the end of a lane with clipped linden trees alongside it, Bentinck's garden pavilion appeared. Bentinck himself, most likely with the advice of the Stadholder William III, chose this location. ${ }^{27}$ As an amateur-gardener, Bentinck was actively involved in the architectural design of his garden and grottoes, but who he hired as architect, land surveyor, fountain-maker, carpenters, stonemasons, and gardeners remains unknown. Nor have any sketches nor plans of this building (nor of the garden) survived, provided that these ever existed. This also is the case for a similar grotto, built in 1647-1649 for the Stad-

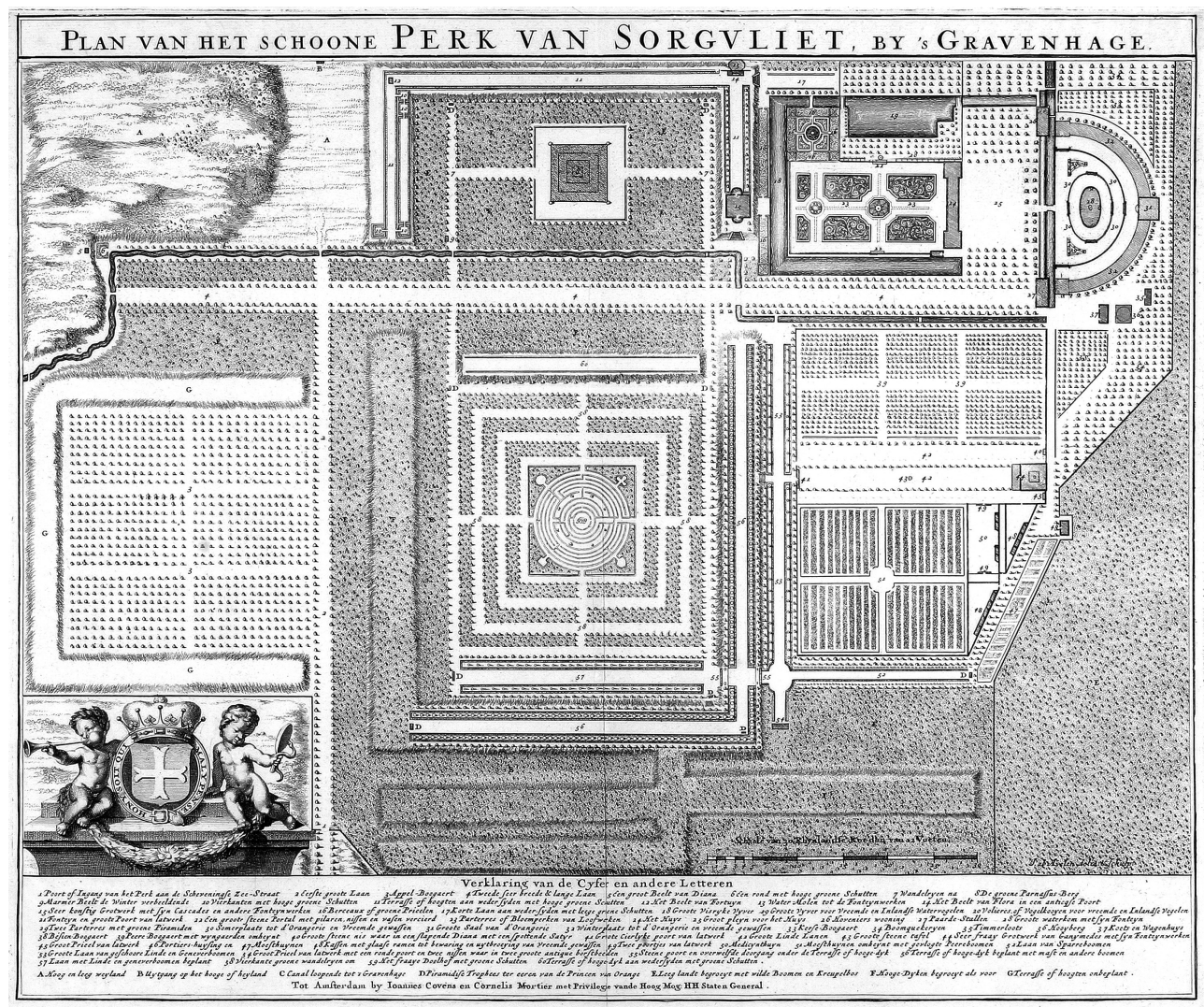

2.1) Jan van den Avelen, Map of Zorgvliet, circa 1690, no. z.gr. 191, Haags Gemeentearchief, Den Haag 
INTO THE LIGHT: CRYSTALS AND THE RECREATION OF NATURE IN SEVENTEENTH-CENTURY GARDEN CAVES AND CABINETS.

holder Frederik-Hendrik's garden at Honselaarsdyk. But here the accounts provide certain names, such as the grotto-builder Joseph Dinant. He was paid for his services, his material, and his workforce, without any specification regarding the various tasks or names of artisans; just one master carpenter was mentioned by name. ${ }^{28}$

Unfortunately Bentinck's workforce remains invisible, but we can draw on one other example close to this case for reference: the garden grotto of Prince Johan Maurits of Nassau in The Hague, which was built between 1668 and 1670 and demolished in $1679 .{ }^{29}$ Bentinck was acquainted with Prince William III's elderly cousin and thus knew the Prince's house and garden in The Hague well. ${ }^{30}$ In 1679, when Johan Maurits learned that the courtier wanted to build a grotto, he offered part of his grotto's contents to Bentinck: a set of thirty-nine looking glasses together with a collection of conches, shells, and three ceramic animals (two snakes and a tortoise). ${ }^{31}$

The Prince furthermore suggested that Bentinck hire his architect Maurits Post. Bentinck may have contemplated using the services of the young architect, who had worked also on other royal gardens and grottoes in The Hague. This promising architect could have done the job, but his untimely death prevented it. ${ }^{32}$ Being so close to the Prince of Orange, Bentinck probably employed people from this circle, since the Stadholder had always been very keen on the Zorgvliet's garden. ${ }^{33}$

In a short period of time, Bentinck needed to assemble a skilled workforce; acquire information on different types of grottoes, collect various grotto ornaments, find a setting for his grotto and have everything brought together as a fine example of artful nature. To render the grotto more 'natural', Bentinck wanted an indoor fountain, something the prince's grotto did not have. An indoor fountain symbolized the origin of water: hidden well below the earth's surface. Constructing a fountain and water conduits was a delicate and costly affair. Water had to be collected, transported, stored and led to the fountain inside. While building the pavilion, the constructors had to take into account how and where the conduits and water container should be constructed, and how to conceal the pipes and reservoir. Designing and building a garden grotto meant looking into existing grottoes for reference and hiring grotto constructors who had experience with these sorts of complex constructions.

Maurits Post was familiar with grotto-constructions, having been trained by his father Peter Post, who was chief architect to the Princes of Orange and Nassau until his death in 1669. Father and son Post worked closely with the French fontainiergrottier Dinant-family. ${ }^{34}$ With this kind of background, it made sense that Johan Maurits suggested the services of this young architect to Bentinck. After Post's demise, Bentinck could have hired a member of the Dinant dynasty, or possibly the fountain-maker/engineer Willem Meester, also in the service of the Stadholder. Meester had built a number of these types of waterworks for several of the Prince of 
INTO THE LIGHT: CRYSTALS AND THE RECREATION OF NATURE IN SEVENTEENTH-CENTURY GARDEN CAVES AND CABINETS.

Orange's gardens. He had further gained insight in the workings of French gardens, water systems, and grottoes since the Prince of Orange had ordered him to go to France for three months in $1679 .{ }^{35}$ Meester viewed the gardens and ornaments and brought his findings back to the Low Countries, and to Prince William. Meester's understanding of water works and artificial grottoes became available to those who hired him, and to those who consulted the collection of books, prints and papers on fountains and gardens he acquired.

One such book was the widely spread publication Traité de Jardinage by Jacques Boyceau. In 1638 he told his readers that garden grottoes

... are made to represent the wild caverns which are cut from natural rocks or built specially elsewhere, also these are usually kept dark and certainly not gloomy. They are ornate with rustic products and material objects that fit with this style, such as porous and concave stones, pieces of rocks and curious pebbles, conches and strange fossils, and other types of shells, which by their well ordered forms and colours are beautiful enhancements: the water pipes are clean and well fitted, rendering the things most natural. ${ }^{36}$

Prince Johan Maurits' grotto came close to Boyceau's description as it resembled a miniature mountain adorned with boulders. This windowless grotto housed not only shells and conches, but also thirty-nine looking glasses and a stove. The mirrors made this grotto lighter, and the stove made it agreeable on colder days.

Johan Maurits' problems with his garden grotto in The Hague shed some light on the construction and the maintenance of these complex garden objects. In this grotto, shells and conches regularly fell from the walls because of a combination of heat and infirm cement. ${ }^{37}$ Post informed the Prince by letter on this matter, but he did not specify whether the problem of the cement had anything to do with the heat of the grotto's iron stove or due to hot weather conditions. ${ }^{38}$ There is no record of this sort of problems regarding the Grotto of Ganymede; therefore it cannot be ascertained whether Bentinck suffered similar problems. ${ }^{39}$ Maybe the constructors had overcome the problems with cement, or the answer was in the structure of the Ganymede grotto.

Although the Grotto of Ganymede housed a large part of the contents of Johan Maurits' grotto, it differed greatly in overall design. In style and construction the forerunner of Bentinck's grotto was the Grotto of Thétis, in the garden of Versailles. ${ }^{40}$ The Grotto of Ganymede had a symmetrical façade that was divided into four sections by pilasters. [see picture 2.2] In the middle was an arched entrance with left and right arched windows; the flat roof had an octagonal windowed cupola in 
INTO THE LIGHT: CRYSTALS AND THE RECREATION OF NATURE IN SEVENTEENTH-CENTURY GARDEN CAVES AND CABINETS.

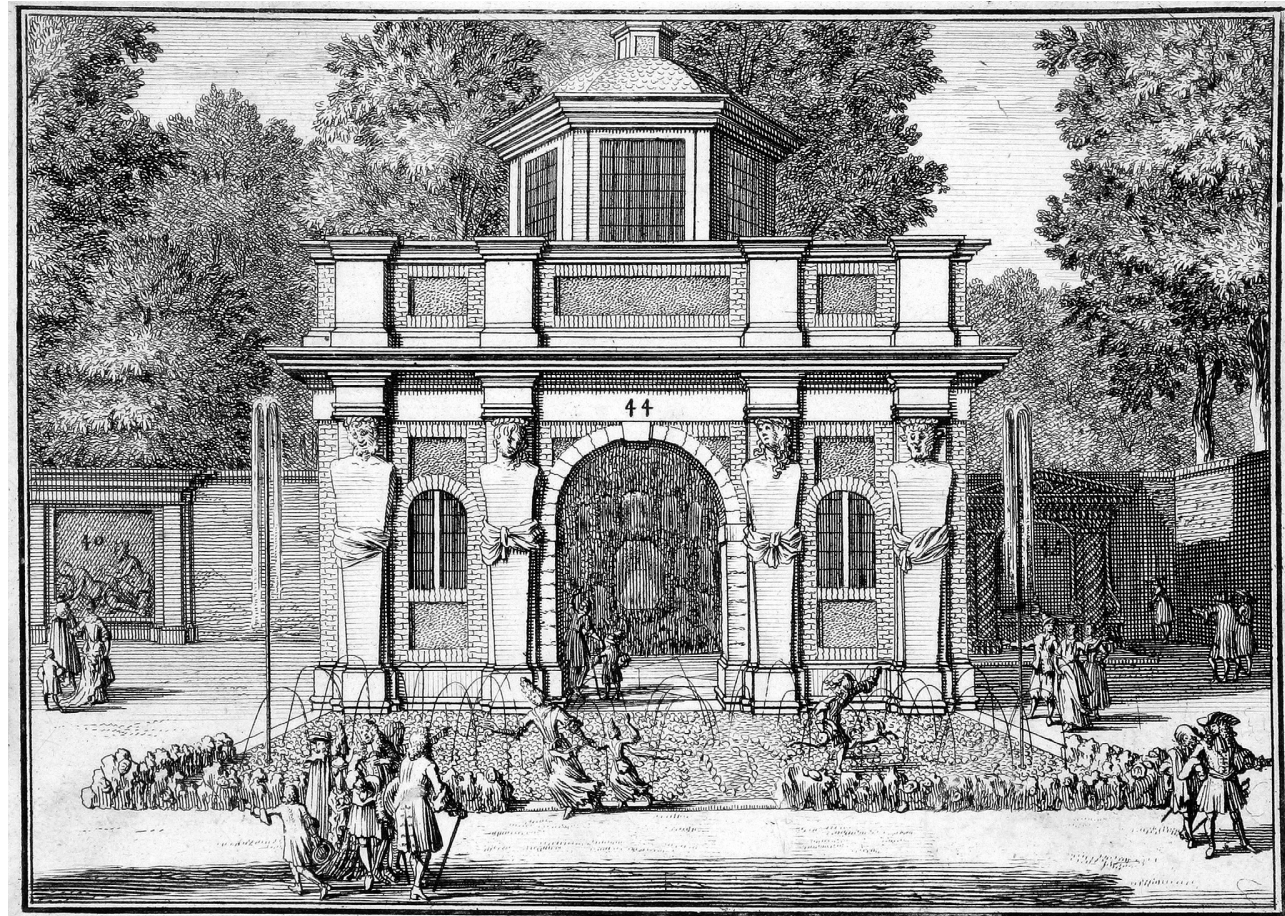

Het fraye Grot van Ganimedes $\mathbf{N}^{\circ} 44$ met zyn fonteynwerken van buyten, de Nis N: ${ }_{4}$ o met de flapende Diana en't groote Prie el van latwerk $\mathbf{N}_{45}^{\circ}$.

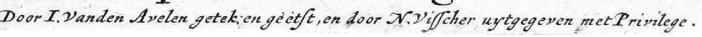

2.2) Jan van den Avelen, Grotto of Ganymede, exterior, circa 1690, no. k1. B 1513, Haags Gemeentearchief, Den Haag

its centre. Inside, the pavilion functioned as a hall with a tiled floor, stone benches along the wall and large looking glasses hanging opposite the windows and the entrance. Opposite the door was a large niche furnished with waterworks, mirrors, shells, rocks and other ornaments. An oval fountain kept the visitor from entering the niche; nature's secrets could not be inspected closely. [see picture 2.3]

Before the final completion of the Ganymede pavilion, as just described, the constructors had to build a structure with water conduits, a reservoir, and a fountain that needed then to be adorned (the fountain) and hidden (the conduits and reservoir). The final stage thus entailed the beautification of the grotto. Probably in early 1680 , Bentinck's constructors started to hang Johan Maurits' expensive glass mirrors ${ }^{41}$ in a symmetrical fashion against the curved back wall of the niche to reflect light and water. They filled the rest of the niche with the other objects from the Prince's old grotto. ${ }^{42}$ Now all the constructors had only to wait for the Lingen crystals to arrive at The Hague. 
INTO THE LIGHT: CRYSTALS AND THE RECREATION OF NATURE IN SEVENTEENTH-CENTURY GARDEN CAVES AND CABINETS.

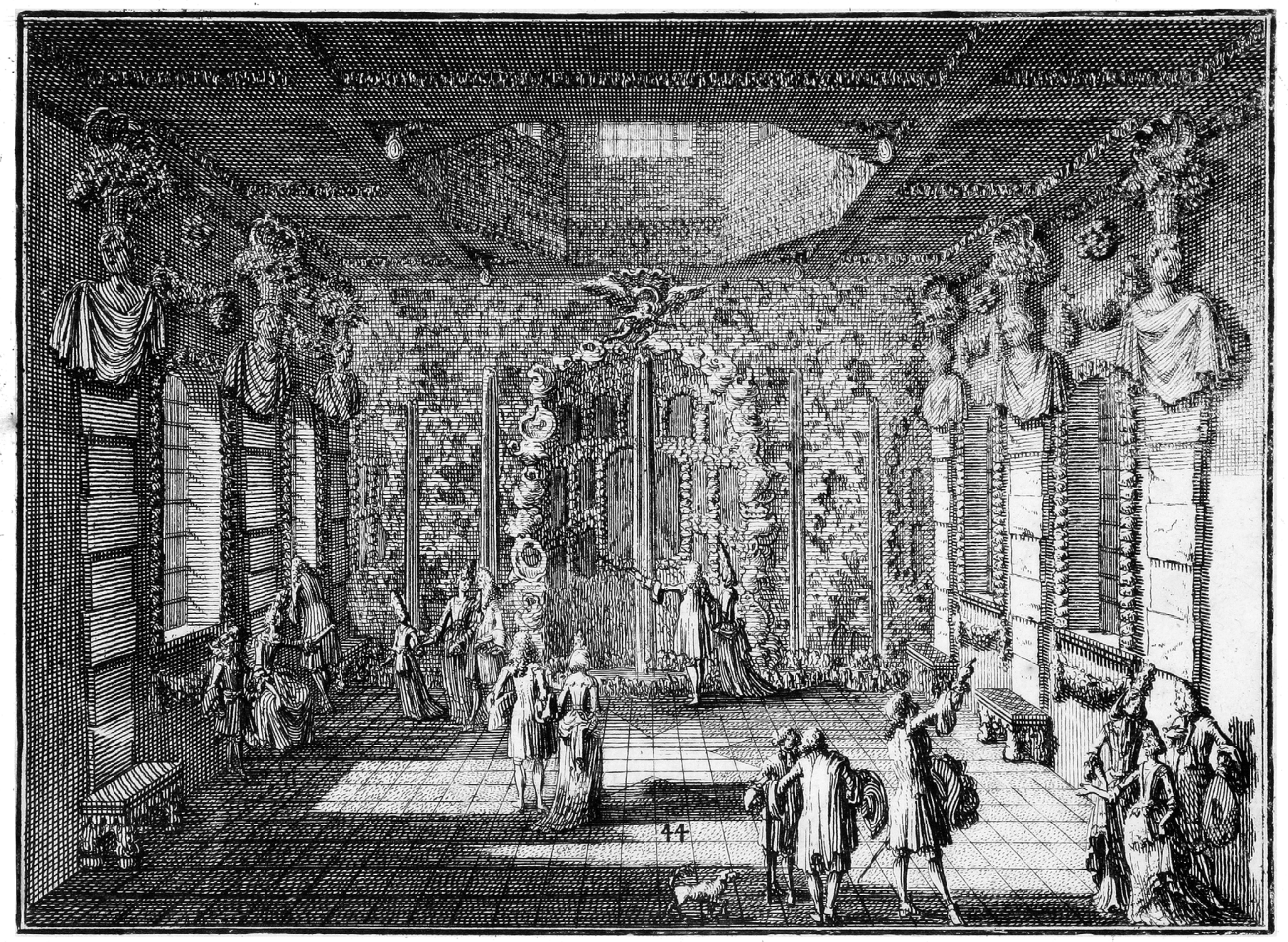

Het fchoone Grot van Ganimedes $\mathbb{N}^{\circ} .44$ van binnen.

2.3) Jan van den Avelen, Grotto of Ganymede, interior, circa 1690, no. kl. B 1514Haags Gemeentearchief, Den Haag

Late in 1680, these stones finally arrived to complete the grotto's change from an engineering project into an artful imitation of nature, by covering the walls, faucets, gaps, water conduits, and walls from top to bottom. First, the rock crystal needed to be sorted, cut into manageable sizes, and cleaned before being cemented into place. Then the constructors assembled the rocks in the grotto and cemented them around the fountain, so that they rested firmly in their manmade cave. Without any written source it remains speculative how the constructors positioned the crystals and mirrors like pieces of a puzzle. However, their goal was to make each element reflect and refract light from one point to another in order for this optical spectacle to work. Thus adapted and exposed, the crystals showed off their natural and orderly beauty, while playing tricks with light and sight. This was the last step in the transformation of the rocks from an invisible element in the earth's bowels to an artfully enhanced object of nature. 
INTO THE LIGHT: CRYSTALS AND THE RECREATION OF NATURE IN SEVENTEENTH-CENTURY GARDEN CAVES AND CABINETS.

Carefully placed in the grotto, the crystals and corals symbolized the earth; the ceramic snakes and tortoise as well as shells, conches and corals signified the fertile quality of water. ${ }^{43}$ Brought out in the open, light shone on nature's otherwise hidden mystery: the origin of the crystals was now exposed to the public. The common notion was, as the Huygens' correspondence informs us, that crystals grew in the darkness of a cave. But here, daylight entered via the door, the windows and from the copula above to shed light on this event. Inside, rays of light reflected from the mirrors and scattered throughout the grotto while being refracted by the water drops and the shiny crystals. Light revealed nature's secrets, while the multiple reflections and refractions created an optical spectacle.

The geometrically hung mirrors played an important part in this cunningly orchestrated optical trick. Set in a semicircle, these looking glasses seemingly dissolved the wall, making it difficult for the visitor to see how deep the niche really was. Furthermore, the mirrors reflected each other, the interior, the visitors, the ornaments and parts of the world outside the niche and the grotto. This distorted the boundary between what was real and what was unreal for the observer ${ }^{44}$ Did one see the actual object or daylight, its reflection, or a reflection of a reflection? This complex manipulation set in play by the grotto's constructors, harnessed daylight, reflection and refraction in order to trick the visitor. ${ }^{45}$ Visitors, in turn, could simply enjoy the grotto for its pleasing trick or examine this optical illusion and find out how nature symbolically 'worked', ranging from its life-giving qualities, to its order and symmetry.

The crystal's even-sidedness together with the symmetrically placed mirrors and windows referred to nature's mathematical design. Placed in this artificial surrounding, these objects of inquiry and delight symbolized the mathematical order of God's Creation. The reflected and refracted light pointed to the motion of light. The constructors illustrated their understanding of the mechanics - if not the mechanical laws - of light's motion through the way they manipulated it. Rays of light came in through the windows and flooded the grotto; it was reflected by the mirrors and refracted through the water drops and crystals. The passage of light triggered this optical spectacle, thoughtfully engineered by the grotto constructors.

Bentinck and his workforce built a representation of spectacular, orderly nature, by combining and processing natural knowledge, engineering, nature, and art. Seamlessly combined, the constructors transformed the once hidden objects of nature into an entertaining and enlightening art object. This entailed transforming the Lingen crystals from unseen objects to objects that embodied nature's working. Simultaneously it required the combined manual and mental expertise in grotto construction to realize a building that was also represented nature. 
INTO THE LIGHT: CRYSTALS AND THE RECREATION OF NATURE IN SEVENTEENTH-CENTURY GARDEN CAVES AND CABINETS.

This grotto addressed nature's enhanced beauty and Bentinck's position as courtier and diplomat. The crystals connected the county of Lingen to Bentinck's office and the Dutch Republic. The gifts from the elderly Prince Johan Maurits of Nassau acknowledged the young Bentinck as an important servant to the Stadholder. Bentinck himself advertised this role by naming his garden pavilion the Grotto of Ganymede, the cupbearer to the gods; in this case, celebrating his position as servant to Prince William of Orange, Stadholder of the Republic and King of England.

The Grotto of Ganymede became a topic discussed amongst grotto visitors and constructors. The English gentleman-tourist Thomas Bowrey described the grotto in 1698 as "Curiously [set] with Shells, Rock Corall and Lookinglasses, and in it a Fountain." "It It contained various objects of nature and artifice assembled together to evoke nature's orderly beauty and curious variety. In a sense, a grotto was a type of Wunderkammer, as it housed a collection of objects that played with the subtle transition between nature and artifice. And like a Wunderkammer it showcased a collection of playful naturalia displaying nature as artist. ${ }^{47}$ The constructors merged the artistic talents of humans and nature in order to magnify nature's mechanisms, and to showcase the manifestations of nature's bizarre beauty for their unique properties. ${ }^{48}$ Collecting, ordering, polishing, and investigating the form and the refractive nature of crystal was part of this activity.

Nobles, amateurs, and savants met in curiosity cabinets to admire, discuss, and investigate nature's objects. These actors collected and appreciated the sort of rock crystal that illuminated Bentinck's grotto for its regular hexagonal shape and the way it dispersed light. They amassed other types of crystal for their colour, their shape, or for their unique and strange refractive qualities, as happened with the Iceland crystal. King Frederik of Denmark had this type of crystal on display in his curiosity cabinet for interested visitors and savants to see and admire. Both Frederik's Wunderkammer and Bentinck's grotto were, though in different ways, connected to the inquiry into the nature of light. The mathematician Erasmus Bartholinus studied the Danish King's Iceland crystal, whereas Christiaan Huygens studied the Lingen rock crystal, which he got thanks to Bentinck's grotto. ${ }^{49}$

Neither investigation into the operation of nature nor the transformation of the Lingen crystals took place solely in the Grotto of Ganymede. This process occurred almost simultaneously in the chambers of Christiaan Huygens as part of his quest to expose nature's order and beauty. It led to a reconstruction of nature on paper. With the help of Constantijn's Stadholderly connections, some of the Lingen crystals were transported to Huygens' quarters, where he could transform these rocks into objects of inquiry into nature. 
INTO THE LIGHT: CRYSTALS AND THE RECREATION OF NATURE IN SEVENTEENTH-CENTURY

GARDEN CAVES AND CABINETS.

\section{Christiaan Huygens: Examiner of crystals}

In Zorgvliet's garden grotto, the Lingen crystals showed how the garden constructors used art to enhance nature thereby imposing their rules to restore God's orderly and beautiful design. While Bentinck's workforce imposed nature's order and beauty, almost at the same time in Paris, Christiaan Huygens inquired into the nature of crystals while considering artifice as the creator of their natural beauty and order. Even though these approaches regarding art and nature differed, both artisan and savant were entailed in producing material and knowledge while investigating nature's divine design.

Christiaan, like the grotto constructors, collected and processed objects, books and information to help him reveal the crystal's hidden secrets. He polished, cut and carved crystals while rendering them in ink by drawing, schematizing, and describing. Furthermore, Huygens read and wrote about the various types of crystal, and discussing their various aspects with his brother Constantijn and other members of his extensive network. Both the savant and Bentincks's artisans tinkered with crystals but with different outcomes. The details of Huygens' process culminated in his Traité de la Lumière, published in 1690.

Christiaan became interested in crystals from the first time he viewed the Iceland crystal in 1672 together with the Danish mathematician Erasmus Bartholinus' booklet on the Iceland crystal's strange refraction, Experiementa crystalli islandici disdiaclastici (published in 1669). ${ }^{50}$ The Iceland crystal's two characteristics are that it has a double refraction: light breaks into two beams, which happens in certain crystals. But it has a strange refraction as well, as one of the two rays refracts differently: it is perpendicular and passes at a different angle. ${ }^{51}$ Huygens' search for an explanation of the strange refraction and his growing expertise in the field of lensmaking were inextricably part of his larger inquiry into the nature of light. Nature, knowledge and art experientially composed a seamless web in Huygens' work.

Huygens eagerly wanted to investigate Iceland and rock crystals for the way they refracted light, but he struggled - both mentally and manually - his material. In 1677 he wrote to the French minister of state Colbert that this "little wonder of nature" was most difficult to penetrate. But this only strengthened his resolve to pursue the truths and hidden beauties that remained locked within this ill-proportioned object. ${ }^{52}$ This process of revealing its secrets entailed endless tinkering - both direct and through representational sketches - with the crystals.

Two years later, Christiaan wrote to his brother that he "found a way to cut and polish this crystal, which I was increasingly determined to do because everyone 
INTO THE LIGHT: CRYSTALS AND THE RECREATION OF NATURE IN SEVENTEENTH-CENTURY GARDEN CAVES AND CABINETS.

believed it to be impossible." ${ }^{53}$ In his treatise, Christiaan informed his reader how he went about it; how he first tried the common method of polishing, which he had to adapt. ${ }^{54}$ Not only was Huygens busy with polishing Iceland crystals. He simultaneously tried to find new ways to "perfectly polish glass" to make optical lenses. ${ }^{55}$ Along with the secrets of nature, Huygens was also determined to penetrate the secrets of grinding which were being kept from him by "our little widow Le Bas." Huygens, thus, combined hands-on contemplation with mindful manipulation in order to reach his goal.

Over the years, Huygens amassed different types of crystal for his inquiry into nature. So when he learned about the existence and shape of Lingen crystals, he wrote in reply to Constantijn's letter (see above) that "[s]ince I am a great examiner of crystals and their refraction, I would eagerly wish to see several good transparent pieces of this. You can easily have them sent with Mons. Bentingh's shipment." ${ }^{\text {}} 7$ It is not certain when Christiaan finally got the Lingen rock crystal, but it was not before 1683 .

Constantijn, constantly looking out for his brother happened to be in Dieren in 1684, visiting one of the hunting castles of Prince William of Orange. The garden of this country estate housed two grottoes, both of which were adorned with various crystals, amongst others things. Constantijn took small samples from two of the grottoes' large crystals and sent them to his brother. He explained that the white one was of the sort that came from the Lingen region and in regular shapes "like the real rock crystal." Furthermore, he wrote, these crystals could be cut and broken in parallel pieces, giving them a shiny surface. ${ }^{58}$

The other sample of the Dieren crystal was fairly heavy, and Christiaan wondered whether it contained any metal. In any case, he wrote to Constantijn, it was probably not from a rich mine, which would explain why it was used for adorning a grotto. ${ }^{59}$ So, for Christiaan's inquiry into nature, not only the crystals from the Grotto of Ganymede but also those from the grottoes of the Stadholder's hunting castle were of interest. And yet, Christiaan seemed not to have thought highly of garden grottoes as providing a nurturing home for crystals, claiming as he did that such a setting displayed them as nothing more than objects of admiration. Rock crystal should serve a greater purpose, he argued, as objects of commerce or examination. The Huygens's considered artisans and miners as two groups of people who worked with nothing more than their hands and tools, with little concern for the crystals' hidden knowledge. Crafted by artisans into mere ornaments, the miners had given these crystals away as gifts to adorn a garden grotto. How else might this be understood than as corroborating evidence for the social and intellectual superiority of the gentlemangeomètre and his examination of nature's laws? 
INTO THE LIGHT: CRYSTALS AND THE RECREATION OF NATURE IN SEVENTEENTH-CENTURY GARDEN CAVES AND CABINETS.

An apprehension of Huygens and his work rests somewhere between this socially embedded set of distinctions and his practical engagement with various sites of production and display. Ironically, perhaps, it is precisely because he was situated on a highly-placed social rung that gave him access to aristocratic and princely gardens that he also gained access to the handiwork of those he socially denigrated. Had it not been for the garden owners and their grottoes, decorated with the various representations of nature, as well as Constantijn's inquisitive eye and grabbing hands when admiring these extraordinary objects, Christiaan would not have had all these different crystals at his disposal. The fashion to reveal nature's secrets in a garden grotto fuelled Huygens' revelation of nature's orderly beauty. Without the miners' by-product having found their way into a socially exclusive setting, his collection of crystals and, thus, his inquiry into nature could not have been so extensive.

As secretary to Prince William, Constantijn followed the Stadholder on his travels. This not only enabled Constantijn to visit different sites but also to build an extensive network. One of his connections was the Amsterdam silk-merchant Philips de Flines. This wealthy amateur and garden-enthusiast had mentioned to Constantijn that he could obtain Iceland crystal for Christiaan from his mercantile contacts. Christiaan quickly invited De Flines to come to Paris in 1679, where he introduced him to collectors of curiosity, artists and printers and took him to bookshops and gardens. The gardener-merchant, in turn, also agreed to send some of his flower seeds to the King's botanic garden. His promises, however, were easier made than kept. ${ }^{60}$ Christiaan had to ask his brother on several occasions by letter to remind De Flines of his word. ${ }^{61}$ This made it difficult for the brothers to ascertain the reliability of De Flines. The contact ended after 1681, without any indication that Huygens received the Iceland crystals.

De Flines' promise brought him in close contact with this well-connected and learned family that had strong ties with the Stadholder and the Académie Royale des Sciences. The merchant's collection of natural history and art became even more socially prestigious through his relation to Christiaan and Constantijn. For instance, De Flines obtained via Christiaan a microscope, with which he viewed plants and insects taken from his garden. Huygens's civil conduct on the other hand was induced by the possible acquisition of the precious Iceland crystal.

This manner of social conduct ran more or less parallel to the acquisition of grotto information and objects by owners/constructors of grottoes, whereby courteous prestige motivated the act of giving and sharing. Constantijn's network, thus, enabled Christiaan to collect books, information and crystals, which he then could use for his inquiry into nature. By cutting, breaking, polishing, sketching, and comparing the different crystals and combining his findings with information received from Bar- 
INTO THE LIGHT: CRYSTALS AND THE RECREATION OF NATURE IN SEVENTEENTH-CENTURY GARDEN CAVES AND CABINETS.

tholinus, the Lingen miners, Constantijn and other geomètres, Huygens constructed his understanding of nature.

Huygens manipulated all these different types of crystal manually, on paper, and mentally in order to apprehend the formation, the shape and the refractive uniqueness of the crystal while trying to understand the laws of light. ${ }^{62}$ The "great examiner" cut and polished the crystal into different shapes using various techniques, such as treating it with almond oil to smooth the surface and make it transparent. He reworked the crystal into pyramidal, cubic, pentagonal, and hexagonal shapes and compared their single and double refractions ${ }^{63}$ Like his counterparts building a grotto, he worked with nature, using mathematical tools, chisels, pen and paper, in order to understand and display its workings. The garden constructors' goal was to represent physically an enhanced nature; Huygens' transformation of nature became a construction of words, diagrams, and drawings. This operation entailed manual and mental labour, using art to reveal nature's geometrical form: by way of cutting and chiselling the crystal, by making schematic drawings of the crystal, and by depicting light in geometrical shapes.

Huygens appreciated the beautiful regularity of rock crystals, which he understood to be made from well-ordered particles. In his Traité de la Lumière he mentioned that he

...had observed a certain phenomenon in the ordinary [Rock] Crystal, which occurs in hexagonal form, and which, because of this regularity, seems also to be composed of particles, of definite figure, and ranged in order. ${ }^{64}$

This regularity contrasted with the Iceland crystal. He disliked its irregular shape and found it difficult to understand the workings of this wonder of nature, as he informed Colbert by letter in $1677 .{ }^{65}$ But he persisted in his quest to understand this complex and ill-proportioned crystal.

The crystals signified the uniqueness and variety of nature's elements, as well as nature's geometrical regularity and order. Jointly, variety and order formed the Janus-faced foundation of divinely created and humanly represented nature. The uniqueness of the Iceland crystal and the regularity of the rock crystal were manipulated and contemplated in the study and grotto as examples of the wonders and workings of nature. Huygens strived to expose nature's order and regularity by using nature's intriguing variety, whereas the grotto constructors used geometrical order to accentuate nature's uniqueness and wonder.

In the grotto and in the treatise, variety and order entwined to form the foundation of both divinely created and humanly represented nature ${ }^{66}$ The Grotto of Ganymede 
INTO THE LIGHT: CRYSTALS AND THE RECREATION OF NATURE IN SEVENTEENTH-CENTURY GARDEN CAVES AND CABINETS.

emphasized the complex mixture of nature's wonder and irregularity; here shells, conches, and fossils represented nature's strange but playful forms. Bentinck's constructors merged nature with art to form a well-organized and geometrical pavilion where its content could be appreciated for its curious beauty and optical delight.

Huygens on the other hand emphasized nature's regularity and order in his treatise. He needed the regularity of the rock crystal and the uniqueness of the Iceland crystal for his inquiry into light, and he transformed both rocks into schematic depictions in his treatise. Huygens opted for the schematized drawing since this underscored his argument of how light passed through this crystal. The rock crystal embodied nature's geometrical order, whereas the Iceland crystal showed nature's uniqueness. For Huygens the curiosity of the Iceland crystal was its refraction and not its actual shape. Christiaan considered the crystal an ill-proportioned but interesting object, and not an example of nature's playful artistry ${ }^{67}$ As such, he chose not to include an actual drawing of this strange crystal in his book, since it would only distract the reader from his treatise on light. ${ }^{68}$

The irregular form of Huygens' Iceland crystal contrasted with the orderly shape of the rock crystal. In both of his pre-press manuscripts of 1689, he described his piece of Iceland crystal. But the description never made it to the final publication of the Traité de la Lumière. The unpublished section reads

the greatest piece I have seen of the latter is the length of a thumb, has the shape of a cylinder, but is overall imperfect, irregular and pocked with cavities... at two ends it has... obtuse angles, composed of three angles of 101 degrees each. ${ }^{69}$

Accompanying this text on folio 216r, Huygens had made a drawing of his piece of Iceland crystal. [see picture 2.4], which he crossed out in the pre-press manuscripts of the Traité. The original illustration and description showed a crystal with angles of varying degrees and different axes. This stood in opposition to the geometrical depiction of the Iceland crystal, which was found on folio $215 \mathrm{r}$ in the manuscript [see picture 2.5]. For the printed version, Huygens opted to include only this schematized drawing of the Iceland crystal, and against the realistic depiction and description of the Iceland crystal. He discarded nature's 'flawed' form that worked against his emphasis on nature's beautiful order and regularity. He remained, nevertheless, intrigued by the formation of the hexagonal rock crystal.

In search of an answer, he wanted to know more about the crystal's natural environment. Christiaan asked his brother about the location and type of earth in which the Lingen crystal grew that might help account for its shape. ${ }^{70}$ Constantijn explained 


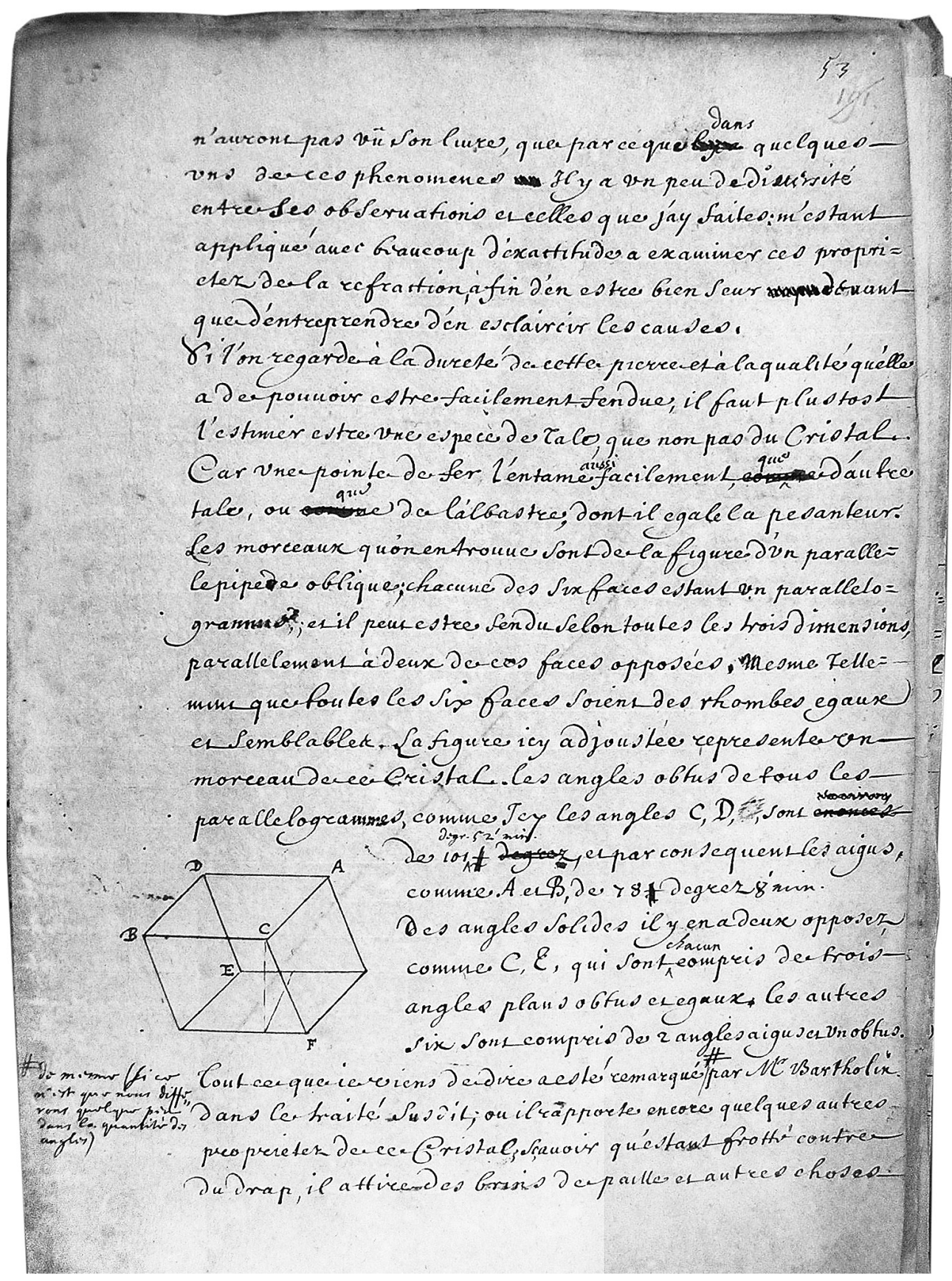

2.4) Christiaan Huygens, Manuscript Traité de la Lumière, circa 1690, HUG 31 fol. 216r, Special Collections, University Library Leiden, Leiden 
INTO THE LIGHT: CRYSTALS AND THE RECREATION OF NATURE IN SEVENTEENTH-CENTURY

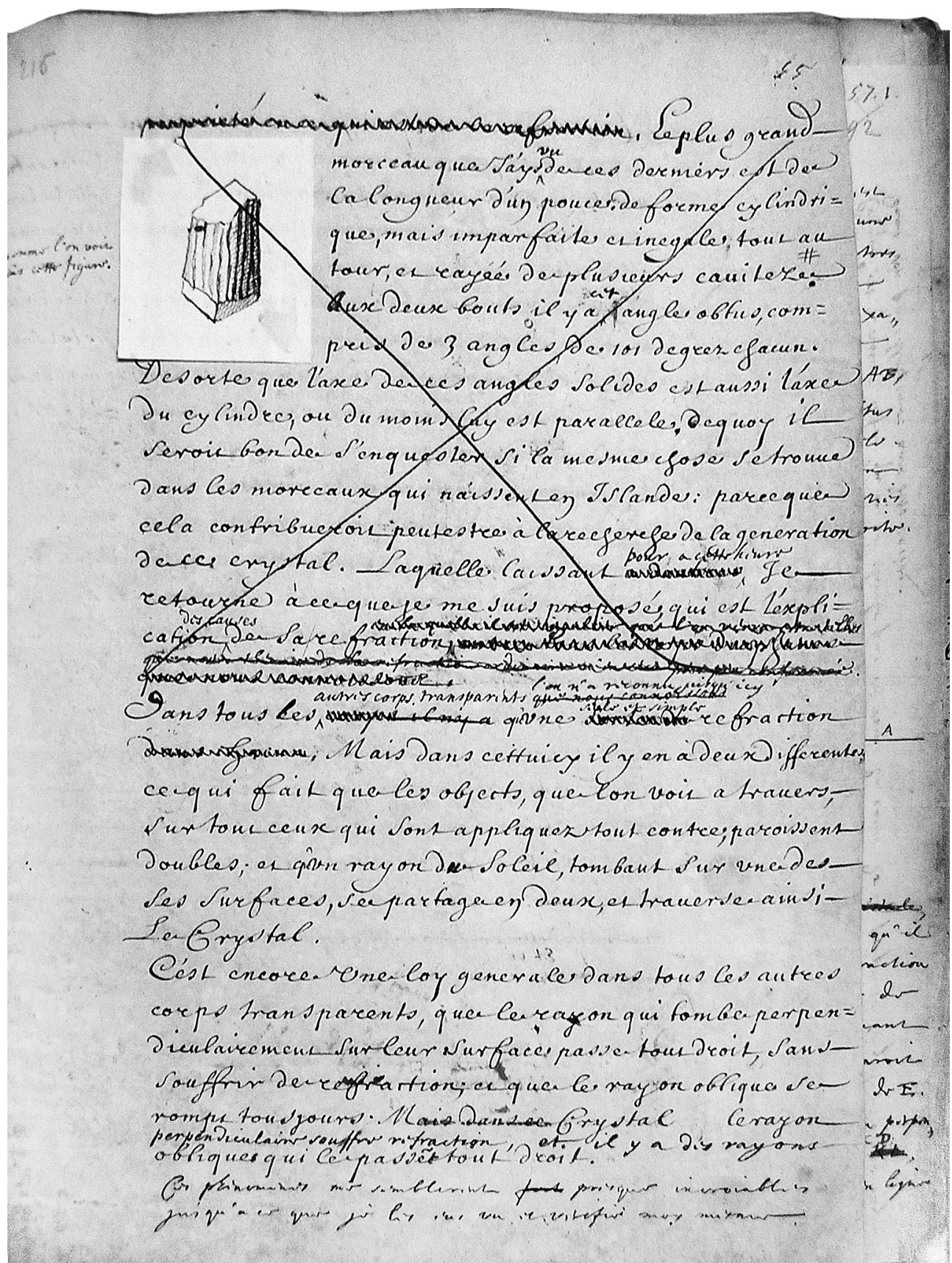

2.5) Christiaan Huygens, Manuscript Traité de la Lumière, circa 1690, HUG 31 fol. 215r, Special Collections, University Library Leiden, Leiden 
that the crystals grew (the Huygens' brothers used the word croître in reference to the crystal's original environment) in a cave deep in a mountain. It was here that the crystals gained their form. Back in his chambers, Christiaan puzzled over the formation of nature's geometry which he believed to consist of orderly composed particles. How did the crystal get its shape? How did this happen with the "many bodies, vegetable, mineral, and congealed salts, which are formed with certain regular angles and figures?" He found that

All these things deserve careful investigation to ascertain how and by what artifice nature operates... It seems that in general the regularity which occurs in these productions comes from the arrangement of the small invisible equal particles of which they are composed..$^{71}$

Huygens admired the beauty of nature's geometry and the regularity of the composition of the particles, but he was unable to explain nature's 'beautiful order'. This continued to elude him, which made him wonder all the more about the formation of crystals. While searching for an answer, he wrote that he didn't yet dare

... to say anything about how such tiny, equal and similar corpuscles are produced, whether they are formed first and then assembled, or whether they arrange themselves in the process of being born and to the extent that they are produced, which seems to me most likely. To develop truths so recondite requires a knowledge of nature much greater than that which we now have. ${ }^{72}$

Even after lengthy investigation into the nature of the crystal, together with new information on its original 'birthplace' Christiaan was still not able to reveal how the crystal got its form and by what artifice nature operates. All he could do was to speculate on the mechanism of their regular formation.

Huygens had much to say about the working of light in his treatise, but the question regarding the formation of nature's geometry remained unanswered. It might therefore be argued that it was thus not in Huygens' cabinet, but in a garden grotto that the representation of nature's beautiful geometrical order and its curious marvels were most revealingly achieved. The constructors offered their version of the working of divine order by mentally and manually weaving together order and variety, art and nature. By merging the natural and the artificial they recreated an enhanced 'belly of the earth'. The grotto constructors found a cunning way to present their understanding of nature's beautiful truths and expose the formation of its geometry; they aesthetically 'succeeded' where Huygens failed. 
INTO THE LIGHT: CRYSTALS AND THE RECREATION OF NATURE IN SEVENTEENTH-CENTURY

GARDEN CAVES AND CABINETS.

\section{Conclusion}

As quoted at the beginning of this paper, Penson and Huygens signaled a link between art and nature. In the garden of Zorgvliet, humans imposed the orderly rules of art onto nature, whereas Huygens' starting point was a belief that artifice is the tool with which God ordered nature. Garden constructors imposed their views of nature's geometry to transform and embellish their landscapes. In his quarters, Huygens tried to explain nature's own design and to reveal its hidden geometrical truths.

The transformation of nature took another step in the grotto, where light, mirrors and crystals were configured to form a cunning optical trick while manipulatively revealing nature's geometrical beauty and the motion of light. Bentinck and his constructors combined their skilled and intellectual labours regarding engineering and nature, geometry, tools, prints and books to project an optical illusion. They amassed natural and artificial curiosities from two main sources, the Lingen mine and Johan Maurits' grotto, and adapted them to this newly built environment. The accumulation of information and objects led to the design of the grotto that revealed both nature's playful artistry and its orderly workings.

Up to 1690, Christiaan Huygens examined crystals and their refraction by using various tools, such as geometry, chisels, metal plates, almond oil, pen and paper to reveal the nature of light. Huygens represented his geometrical adaptation of nature in schematic depictions and writing, thereby deciding in the final stage to discard what seemed to be evidence of nature's inexplicable irregularity. Tinkering with Iceland and rock crystal, Huygens uncovered the workings of the strange refraction and he revealed the rules of refraction. While manipulating and contemplating different crystals he tried to understand the crystal's formative secret, but was finally forced to give up his goal of finding the truth regarding nature's orderly formation.

Searching for nature's truths enabled Bentinck's constructors and Christiaan to find a way to expose its hidden workings. This inquiry into the nature of crystals was an activity, whereby both Bentinck and Huygens relied on the knowledge and knowhow of other people. A network consisting of Constantijn Huygens, Prince Johan Maurits, Philips de Flines, several grotto-constructors and fountain-makers, Prince William of Orange, and the miners from the county of Lingen tied the Grotto of Ganymede to the Traité de la Lumière. Each member of the network transformed the crystal into an object that exposed its inner beauty and truth. The miners revealed the crystal's protective quality, the grotto-constructors revealed nature's orderly beauty, and the mathematician revealed the laws of refraction.

A collaboration of minds and hands, motivated by the crystal's geometrical shape and the way it reflected light, laboured to expose and understand the nature of these 
rocks. The revelatory goals of the grotto and the treatise differed, but their creators' practices and intentions were akin. Bentinck's constructors, like Huygens, paired variety and wonder to geometry and order for their constructive understanding and depiction of nature. Huygens emphasized order and geometry in his book. Though he used variety and wonder for his inquiry into nature's workings, he decided to suppress this in the end since it led attention away from nature's regularity. Bentinck's workforce emphasized nature's wonder and imposed geometry onto nature while using the arts to 'explain' nature. They merged variety and order so as to accentuate nature's wealth and splendour.

The manipulation and contemplation of nature by the miners and grotto constructors opened the way for Huygens to proceed with his inquiry into nature, connecting the grand examinateur and his crystals firmly to the Grotto of Ganymede. The Huygens' brothers, however, claimed otherwise. Their high-ranked status strengthened their motivation to stand above the level of labourers and their artistically transformed products. The Huygens' brothers regarded these labourers as incapable of being able to value nature and understand its laws, since their handcraft was motivated by economics and materially directed toward adorning a garden grotto. Conversely, the Huygens's social standing enabled them to gain access to noble garden grottoes filled with natural and artificial objects that miners and artisans had 'merely' retrieved, constructed or embellished. But it was the mindful hands of these labourers that brought these nature's hidden treasures to light, allowing Christiaan Huygens to amass and examine the different types of crystal, and to write a treatise on light. Due to their place in society and gentlemanly concerns the brothers placed themselves above the echelon of nameless labourers and their 'tacit' knowledge of nature. This seventeenth-century elitist distinction has subsequently been prolonged by generations of historians.

Indeed, the attention of historians has rested for too long on the 'internal' intellectual development of the Traité de la Lumière. Huygens' wide-ranging correspondence and his treatises published in the Oeuvres Complètes have supplied historians with plenty material to examine and appreciate his relationship with other savants. But by looking at other letters and by including the two pre-press manuscripts of his treatise $\mathrm{e}^{73}$ in our investigation, this essay draws another picture. Huygens depended on the knowing and doing of a broad range of actors, including miners and artisans, while he harnessed both his own hands and mind to induce the crystal to reveal its secrets. The network of these transformative practices and the revelation of nature connected the Lingen mines, the Grotto of Ganymede and Huygens' cabinet, revealing a collaboration which entailed both material and knowledge production. This intertwined connection and transformation have remained long hidden from us, 
INTO THE LIGHT: CRYSTALS AND THE RECREATION OF NATURE IN SEVENTEENTH-CENTURY GARDEN CAVES AND CABINETS.

partially because the Grotto of Ganymede was demolished some time ago, leaving only Huygens' treatise and his culturally shaped sense of social interactions as our obvious guides to the related histories of material and knowledge production. But now that the productive capacities of mental and manual collaboration are brought to light, the implications for revising our approach to natural inquiry and invention seem crystal clear. 


\footnotetext{
A previous version of this paper was presented at SHOT in Washington DC, October 2007. I would like to thank participants for their comments, and I especially thank Dr. Lissa Roberts, my mentor and friend. A slightly altered version has been published in the journal History of Technology, (29) 2009, pp. 113-139. Editor-in-chief Ian Inkster gave is kind permission to publish it as part of my dissertation.

1 T. Penson, Harl. MS. 3516, f 14, quoted in R.C. Temple (ed.), The Papers of Thomas Bowrey 1669-1713, (London: Hakluyt Society, 1927), p. 52.

2 Christiaan Huygens, Traité de la Lumière, (Leiden: Pieter van der Aa, 1690), p. 91, "Il y a plusieurs corps vegetaux, mineraux, \& sels congelez, qui se forment avec de certains angles $\&$ figures reguliers." And: p. 92: "Toutes ces choses meritent d'estre recherchées soingeusement, pour reconnoitre comment \& par quel artifice la nature y opere."

3 Chandra Mukerji, "Material practices of dominion: Christian humanism, the built environment and techniques of western power," Theory and Society, 31 (2002) pp. 1-34. She discusses how constructing a garden depended on natural knowledge and artistry. Engineering nature was a 'form of purification' of restoring nature to its once perfect 'grand design' of Creation. God had hidden Nature's laws from men because of their sins, see pages 7-8.

4 Art has two meanings, 1) the process of the transformation of nature and 2) the products of human endeavour to imitate nature. See for further reference: J. van der Groen, Den Nederlandtsen hovenier, (Amsterdam: Marcus Doornick, 1670) "de Natuur, die zich veeltijts wanschickelijck vertoont, door de konst kan op-geschickt, op-gepronckt, in goede ordre, cierlijck en vermakelijck gemaeckt worden." E. de Jong, Natuur en Kunst, Nederlandse tuin- en landschapsarchitectuur 1650-1740, (Hilversum: Toth, 1995), pp. 35-38. P. Dear, "Miracles, experiments, and the ordinary course of nature," Isis, 81 (1990), pp. 663-683, notably p. 682, and see also chapter one of this dissertation.

5 See F.J. Dijksterhuis, "Constructive thinking: A case for dioptrics," in P. Dear, L.L. Roberts and S. Schaffer (eds), The Mindful Hand; Inquiry and Invention from the Late Renaissance to Early Industrialisation, (Amsterdam: Edita, 2007), pp. 59-82. He argues the actors' difficulties regarding making a distinction between the disinterested geometre and the professional/ practical mathematician.

6 A.E. Shapiro, "Huygens' "Traité de la Lumière" and Newton's "Opticks": pursuing and eschewing hypotheses," Notes and Records of the Royal Society of London, 43 (1989), pp. 223-247. And: A.E. Shapiro, "Huygens' kinematic theory of light," H.J.M. Bos, M.J.S. Rudwick et.al. (eds), Studies of Christiaan Huygens, Invited Papers from the Symposium on the Life and Work of Christiaan Huygens, (Lisse: Swets and Zeitlinger, 1980), pp. 200-220.

7 See for instance: T. Comito, "Renaissance gardens and the discovery of Paradise," Journal of the History of Ideas, 32 (1971), pp. 483-506. This paper discusses the transformation of nature into gardens. P. Findlen, Possessing Nature: Museum, Collecting, and Scientific Culture in Early Modern Italy, (Berkeley: University of California Press, 1994), see p. 407 where she argues that Europe's leading intellectuals conducted their inquiry into nature in museums. And: W. Eamon, Science and the Secrets of Nature; Books of Secrets in Medieval and Early Modern Culture, (Princeton: Princeton University Press, 1994). Nature, Eamon says, was to be understood through experiments; otherwise its secrets remained hidden.

${ }^{8}$ For more reference, see: B. Latour, The Pasteurization of France, (Cambridge/London: Harvard University Press, 1993), pp. 79-90. B. Latour, "Give me a laboratory and I will raise
} 
INTO THE LIGHT: CRYSTALS AND THE RECREATION OF NATURE IN SEVENTEENTH-CENTURY

GARDEN CAVES AND CABINETS.

the world," K. Knorr and M. Mulkay (eds), Science Observed: Perspective on the Social Study of Science, (Los Angeles: Sage, 1983), pp. 141-170. I. Rhys Morus, "Seeing and believing science," Isis, 97 (2006), pp. 101-110.

9 Christiaan Huygens, Oeuvres Complètes de Christiaan Huygens, (Den Haag: Martinus Nijhoff, 1888-1950), [referred further as OC], vol. 8, no. 2230 Constantijn to Christiaan, 3 October 1680. "En passant a Lingen pour aller a Cell on me fit voir des grosses pieces moitjé terre et moitjé pierre sur les quels croissent certaines pointes comme celles du cristal de roche, et de figure hexagone comme elles : ces pointes que je vis n'avoyent qu'environ un demy pouce de diametre, mais le Richter de Lingen me dit qu'il s'en trouvoit de plus grosses, et que de ce cristal l'on pouvoit faire tailler des cachets et toutes autres choses. Ils l'estiment si peu par la qu'il me dit qu'il avoit envoyé de fort grosses pieces de cette mine a Mr. Benting pur en orner les Fontaines qu'il fait a Sorgvliet."

${ }^{10}$ P.H. Smith, The Body of the Artisan, Art and Experience in the Scientific Revolution, (Chicago: University of Chicago Press, 2004). She discusses at length the role of artisans as active knowers of nature, which I will not repeat here.

${ }^{11}$ G. Schreiber, Der Bergbau in Geschichte, Ethos und Sakralkultur, (Cologne: Westdeutscher Verlag, 1955). On crystals and their meaning, see pp. 202-206.

${ }_{12}$ W. Cramer, Geschichte der Graffschaft Lingen im 16. und 17. Jahrhundert, (Oldenburg: Stalling, 1940), pp. 82-85.

${ }^{13}$ On the Ibbenbüren coalmine: http://de.wikipedia.org/wiki/Bergwerk_Ibbenbüren, "Erste Zeichen für den Steinkohlebergbau in Ibbenbüren lassen sich bis auf das 15./16. Jahrhundert zurückdatieren. Aufgrund des hügeligen Geländes wurden kleine Schächte und Stllen in die Erhebungen der Landschaft getrieben, um Kohle für benachbarte Kalkbrennereien und Salinen zu gewinnen." This mine is due to be closed in 2009 or 2010. On rock crystal: http://gea-drenthe.nl/nsaksen.html\#ibbenburen, 29 October 2008. "Steenkoollaag uit het boven-Carboon. Naast fossielen zijn uit ertsgangen en spleten in de kolenkalk de volgende mineralen bekend: Bariet $(4 \mathrm{~cm})$, Bergkristal (tot $10 \mathrm{~cm}$, ook Scepter-kwarts), Dolomiet (1,5 cm), kogelvormige Markasiet, Milleriet $(2 \mathrm{~cm})$, Steenzout $(3 \mathrm{~cm})$ em Whevelliet $(3 \mathrm{~mm})$." See for more information on Ibbenbüren rock crystal: http://www.boerseos.de/ ibbenb.php.

${ }^{14}$ OC, vol. 8, no. 2369 Constantijn to Christiaan, 25 September 1684; and no. 2368 Christiaan to Constantijn, 22 September 1684: "cristal de Lingen croit dans une grotte qui est dedans d'une montagne et fort avant en terre a ce qu'ils disent." In the letters of 1679, Constantijn used the word 'mines' whereas in the 1684 correspondence he talked about 'grotto'. ${ }^{15}$ In their letters the Huygens brothers used the word 'croitre' (to grow) when discussing the crystal's natural environment.

${ }^{16}$ S. Taylor-Leduc, "A new treatise in seventeenth-century garden history: André Félibien's "Description de la Grotte à Versailles"," Studies in the History of Gardens \& Designed Landscapes, 18 (1998), pp. 35-50, p 42.

${ }^{17} \mathrm{~N}$. Lefebvre, A compendious body of chemistry: teaching the whole practice thereof by the most exact preartion of animals, vegetables and minerals, preserving their essential virtues, (London: Tho. Davies and Theo. Sadler, 1664), 2 vols. He explains on p. 62 that "Minerals do live, as long as they are joined to their Matrix and Root." Lefebvre expressed the notion that minerals live on as long as they are in their natural state in the earth. 
${ }^{18}$ M. Szafranska,"The philosophy of nature and the grotto in the Renaissance garden," Journal of Garden History, 9 (1989), pp. 76-85. She argues that a garden grotto symbolized lifegiving qualities of earth and water. Plant seeds, stones, and crystals were 'born' in the belly of the earth and metal got its shape there, see p. 79.

${ }^{19}$ Schreiber, Der Bergbau, he argues that working so closely together mine workers were known as 'brotherhood' or 'community', pp. 19-20.

${ }^{20}$ Warren Dym, "Scholars and Miners; Dowsing and the Freiberg Mining Academy," Technology and Culture, 49 (2008), pp. 833-859.

${ }^{21}$ G. Heilfurth, Der Bergbau und seine Kultur, Eine Welt zwischen Dunkel und Licht, (Zürich: Atlantis, 1981), see pp. 26-46; L. Suhling, Aufschließen, Gewinnen und Förderen; Geschichte des Bergbaus, (Reinbek: Rowohlt, 1983), pp. 158-162. And: C.E. Gregory, A Concise History of Mining, (New York/Oxford: Pergamon, 1980).

${ }^{22}$ Schreiber, Der Bergbau, p. 206.

${ }^{23}$ G.J. ter Kuile, "Het graafschap Lingen onder de Oranjes," Verslagen en Mededeelingen van de Vereeniging tot Beoefening van Overijsselsch Regt en Geschiedenis, (s.1., 1953), pp. 13-31.

${ }^{24}$ Latour, "Give me a laboratory".

${ }^{25}$ Maybe Christiaan Huygens got the crystals no sooner than his return to the Low Countries, in 1683 .

${ }^{26}$ Although he had presented his initial findings on the Iceland crystal's strange refraction to the Académie Royales des Sciences in 1679, he published his book in 1690 with new information.

${ }^{27}$ Koninklijk Huisarchief, The Hague, letter from Johan Maurits van Nassau-Siegen to Bentinck, 27 February 1679. He wrote : 'sans doute Son Alt : aura la bonté de vous adviser en ordonnant la place pour la grotte car c'est le principal, de la bien placer...'

${ }^{28}$ Vanessa Bezemer-Sellers, Courtly Gardens in Holland 1600-1650; The House of Orange and the Hortus Batavus, (Amsterdam/Woodbridge: Architectura et Natura, 2001), pp. 352358.

${ }^{29}$ Since the prince could not financially maintain his grotto, he had it demolished.

${ }^{30}$ The Huygens family knew this garden very well, since their residence in The Hague bordered that of Johan Maurits.

${ }^{31}$ Koninklijk Huisarchief, The Hague, letter Johan Maurits to Bentinck, 28 February 1675 “je vours [sic] prie, de me faire l'honeur, j'accepter le petit ornement pour vostre grotte, que vous avez dessein de faire pour avoir une belle vue, soit sur le gradin [sic], ou dans quelque autre endroit, dont la reflexion dans les miroirs sera une belle operation, à Sorgvliet où sans doute Son Alt : aura la bonté de vous adviser en ordonnant la place pour la grotte car c'est le principal, de la bien placer, je vourdroit que j'avis quelque chose de plus grande importance, qui vous pourroit estre agreable, il seroit à vostre service..."

${ }^{32}$ Maurits Post's father Peter Post was also architect to the Stadholder and his family.

${ }^{33}$ N. Japikse, Correspondentie van Willem III en van Hans Willem Bentinck, eersten graaf van Portland, Serie 1, part 1, (Den Haag: Martinus Nijhoff, 1927), pp. 175-179 letter 146 from William III to Bentinck, 14 April 1693. "J'ay esté cett aprèsdine à Sorghvliet où j'ay trouvé tout en asses bon ordre, mais cela a renouvellé mon chagrin de ne vous avoir auprès de moy. Il y aura par tout ce pais peu de fruit cette année, la dernière gelée et niege ayent gâté les fleurs." 
INTO THE LIGHT: CRYSTALS AND THE RECREATION OF NATURE IN SEVENTEENTH-CENTURY

GARDEN CAVES AND CABINETS

${ }^{34}$ Bezemer-Sellers, Courtly Gardens, Joseph, his son Otto and later his grandson Frederic were all fountain-makers, pp. 174-6.

${ }^{35}$ D.J. Roorda, "De loopbaan van Willem Meester," Spiegel Historiael, 16 (1981), pp. 614622. And: E. de Jong, "For profit and ornament: The function and meaning of Dutch garden art in the period of William and Mary, 1650-1702," J.D. Hunt (ed), The Dutch Garden in the Seventeenth Century, (Washington D.C.: Dumbarton Oaks, 1990), pp. 13-48: Meester went there together with Mr Van Nassau-Odijk, the Stadholder's nephew. And: V. Bezemer-Sellers, "The Bentinck garden at Sorgvliet," J.D. Hunt (ed), The Dutch Garden in the Seventeenth Century, (Washington D.C.: Dumbarton Oaks, 1990), pp. 99-129. Page 120 she writes that Prince William and Bentinck sent Meester to Paris.

${ }^{36} \mathrm{~J}$. Boyceau, Traité du jardinage, selon les raisons de la nature et de l'art, (Nördlingen: Verlag Dr. Alfons Uhl, 1997), p. 80. "Les Grotes sont faites pour representeer les Antres sauvages, soit qu'elles soient taillées dans les rochers naturals, ou basties expressément autre part : aussi sont-elles ordinairement tenues sombres, \& aucunement obscures. Elles sont ornées d'ouvrages rustiques, \& d'éstoffes conuenantes à cette maniere, comme pierres spongieuses, \& concaves, especes de roches, \& cailloux bigearres, congelation, \& petrifications estranges, \& de diverses sortes de coquillages, qui par leurs formes \& couleurs bien ordonnées font de beaux enrichissemens : les goutieres \& reiallissemens d'eau, y sont propres \& bien seants, redant les choses plus naturelles.'

${ }^{37}$ Koninklijk Huisarchief, The Hague, letter from Post to Johan Maurits, 7/17 May 1673 "Ick ben meede doende inde grodt al waer door de groote warmte veel schillkens als hoornee af vallen ende verschijde ons mankeeren, ..."

${ }^{38}$ Ibid., letter from Johan Maurits to his accountant/agent Jacob Cohen, 22 February 1679, it mentions an iron stove.

${ }^{39}$ As it turned out, the courtier did not have a heater put into his garden pavilion; this may have safeguarded him from falling shells and conches.

${ }^{40}$ Bezemer-Sellers, "The Bentinck garden at Sorgvliet," pp. 113-14, Bentinck was considered an authority on matters concerning waterworks. See also Japikse, Correspondentie, Serie 1, part 1, and: N. Japikse, Correspondentie van Willem III en van Hans Willem Bentinck, eersten graaf van Portland, Serie 1, part 2, (Den Haag: Martinus Nijhoff, 1928). In the correspondence between Bentinck, William III, the French garden architect André Lenôtre, and others there are many references to gardens, fountains, gardening and water works.

${ }^{41}$ G.A.C. Blok, "De architect Maurits Pietersz Post en de tuin van het Mauritshuis," Jaarboek van Die Haghe, (Den Haag: Mouton, 1940), pp. 60-117, p. 92 Purchased by the architect Maurits Post for the grotto of Johan Maurits, "39 spiegelglasen betaelt die bij monsr alhier gehaelt en ten dienste van zijn F.G. grotte in den Hage verbruijckt zijn f. 170:3:-."

${ }^{42}$ Ibid., p. 92, "voor partij zeehorens en schulpen daervan een gedeelte aen zijn F.G. vereerdt en andere door mijn gecocht zijn ... f. 40:8:-."

${ }^{43}$ On grottoes see: N. Miller, Heavenly Caves, reflections on the garden grotto, (New York: George Braziller, 1982); Szafranska, "The philosophy of nature"; Taylor-Leduc, "A new treatise".

${ }^{44}$ B.M. Stafford and F. Terpak, Devices of Wonder: From the World in a Box to Images on a Screen, (Los Angeles: Getty Research Institute, 2001). See page 25 on mirrors as an instruments for science and for divination. 
${ }^{45}$ Paula Findlen, "Jokes of Nature and Jokes of Knowledge: The Playfulness of Scientific Discourse in Early Modern Europe," Renaissance Quarterly, 43, (1990), pp. 292-331; E. Gombrich, "Review Lecture Mirror and Map: Theories of Pictorial Representation," Philosophical Transactions of the Royal Society of London, Series B, Biological Sciences, 270 (1975), pp. 11-149, notably pp. 120-127.

46 Thomas Bowrey 1669-1713, p. 50.

${ }^{47}$ L. Daston and K. Park, Wonders and the Order of Nature 1150-1750, (New York: Zone Books, 1998), notably pp. 224-27; Findlen, "Jokes of Nature".

${ }^{48}$ On the inquiry and collecting of shells and curiosity cabinets, see: E.C. Spary, "Scientific symmetries," History of Science: an annual review of literature, research and teaching, 42, (2004), pp. 1-46. B. Dietz, "Mobile objects: the space of shells in eighteenth-century France," British Journal of the History of Science, 39 (2006), pp. 363-382.

${ }^{49}$ F.J. Dijksterhuis, Lenses and waves, Christiaan Huygens and the Mathematical Science of Optics in the Seventeenth Century, (Dordrecht/Boston/London: Kluwer Academic Publishers, 2004), notably pages 111 and 142-3.

${ }^{50}$ F.J. Dijksterhuis, "Christiaan Huygens en de mechanica van het licht," M. Keestra and A. Löhnberg (eds), Doorbraken in de natuurkunde, (Amsterdam: Nieuwezijds, 2001), pp. 5780, see p. 64.

${ }^{51}$ For more on Huygens and the strange refraction see: Dijksterhuis, "Christiaan Huygens en de mechanica"; and: Dijksterhuis, Lenses and waves.

52 OC, vol. 8, no. 2105 Christiaan to Colbert, 14 October 1677, “Cristal d'Islande qui n'est pas une petite merveille de la nature, ni aisée a profondir. Je me plains bien souvent de ma destinée d'estre d'une complexion si peu proportionnée a l'inclination que j'ay de travailler a ces belles connoissance."

${ }^{53}$ OC, vol. 8, no. 2201 Christiaan to Constantijn, 3 November 1679, “J'ay trouvè moyen de tailler et de polir ce cristal ce qu'on croioit impossible, et cela me sert fort a ce que j'en ay a faire."

${ }^{54}$ Huygens, Traité de la Lumière, pp. 88-89.

${ }^{55}$ OC, vol. 8, no. 2201 Christiaan to Constantijn, 3 November 1679, “je suis aussie apres a faire quelque nouvelle tentative pour le parfait poli du verre..."

${ }^{56}$ Ibid., no. 2201 Christiaan to Constantijn, 3 November 1679 “... poli du verre que nostre petite vefve le Bas tient fort secrete." She was the widow of glass grinder Le Bas, and keeping Le Bas' way of grinding a secret meant a safeguarding of her livelihood.

${ }^{57}$ Ibid., no. 2235 Christiaan to Constantijn, 20 December 1680, “Comme je suis grand examinateur de cristaux et de leur refractions, je souhaiterois fort de voir quelque morceau bien transparent de cettuicy, et vous en aurez aisement puis qu'on envoie a Mons. Bentingh."

${ }^{58}$ Ibid., no. 2367 Constantijn to Christiaan 18 September 1684, "Ces deux petits morceaux de pierre sont pris de deux grands qui son employés aux Grottes qu'on fait icy. Le blanc est une maniere de Cristal qui croit dans la Comté de Lingen. Il croit en des figures regulieres comme le veritable. Vous verrez qu'il se fend et se casse par des pieces paralleles a la superficie qui est luisante."

${ }^{59}$ Ibid., no. 2368 Christiaan to Constantijn, 22 September 1684, "L'autre morceau semble contenir quelque metail, veu sa pesanteur, mais apparemment ce n'est pas d'une mine bien riche puis que s'en sert a faire des grottes." 
INTO THE LIGHT: CRYSTALS AND THE RECREATION OF NATURE IN SEVENTEENTH-CENTURY

GARDEN CAVES AND CABINETS

${ }^{60}$ Ibid., no. 2201 Christiaan to his Constantijn, 3 November 1679, "J'avois priè bien fort le Sr. Defflines de me procurer quelque morceau de cristal ou talc d'Islande, par ce qu'il me dit qu'un de ses amis negotioit en cette isle de tout le souffre qui s'y receuilloit."

${ }^{61}$ Ibid., no. 2231 Christiaan to Constantijn, 24 October 1680, "Le bon Seigneur de Flines m'avoit promis de m'en procurer de celuy d'Islande par le moyen d'un sien amy, qui negocioit en soulphre dans cette Isle, mais il semble l'avoir oublie. Par occasion je vous prie de luy en parler, comme aussi touchant des fraines de fleur, qu'il avoit promis d'envoier a Mr. Marchand nostre Botanicus du Jardin Royal en eschange d'autres qu'il n'avoit pas. Il s'adresse tousjours a moy pour en avoir des nouvelles parce que je luy ay fait connoistre $\mathrm{Mr}$. Desflinis." ; no. 2238, Constantijn to Christiaan 28 January 1681, "De Flinis m'a mandé que dans peu de jours il croyoit de venir icy et alors je ne manqueray pas de la sommer pour le Cristal d'Islande..." ; no. 2239 Christiaan to Constantijn, 14 February 1681, “...de Flinis avoit promis d'envoier de graines de fleurs a nostre Botanicus Mr. Marchand..."

${ }^{62}$ Huygens, Traité de la Lumière, p. 88, "je diray icy la maniere dont je me suis servi à la tailler, \& à la polir. La taille est aisée par les rouës tranchantes des lapidaires, ou de la maniere qu'on sie le marbre ; mais le poli est tres difficile, \& en employant les moyens ordinaires, on deplit bien plutost les surfaces qu'on ne les rend luisantes."

${ }^{63}$ OC, vol. 12, p. 442

${ }^{64}$ Huygens, Traité de la Lumière, p. 59, “..j’observay dans le cristal ordinaire que croit en forme hexagone, \& qui, à cause de cette regularité, semble aussi estre composé de particules de certaine figure \& rangées avec ordre."

${ }^{65}$ OC, vol. 8, no. 2105 Christiaan to Colbert, 14 October 1677, “Cristal d'Islande qui n'est pas une petite merveille de la nature, ni aisée a profondir. Je me plains bien souvent de ma destinée d'estre d'une complexion si peu proportionnée a l'inclination que j'ay de travailler a ces belles connoissance."

${ }^{66}$ L.L. Roberts, "A World of Wonders, a World of One," in P. Smith and P. Findlen (eds), Merchants and Marvels: Commerce, Science and Art in Early Modern Europe, (New York/ London: Routledge, 2002), pp. 399-411.

${ }^{67}$ Findlen, "Jokes of Nature".

${ }^{68}$ S. Dupré, De Optica van Galileo Galilei, Interactie tussen Kunst en Wetenschap, (Brussel: Verhandelingen van de Koninklijke Vlaamse Academie van België voor Wetenschappen en Kunsten, 2001), vol. 5. He explains how representation is not the same as exact rendering by arguing how Galileo sacrificed accurateness for the sake of an argument.

${ }^{69}$ Christiaan Huygens, manuscript, Leiden University Library, Hug 31 VII 253-312, Folio $215 \mathrm{r}$ 'Le plus grand morceau que j'ay vu de ces derniers est de la longueur d'un poucer, de forme cylindrique, mais imparfaite et inegale, tout au tour, et cayee des plusieurs cavitez [..] aux deux bouts il y a [..] angles obtus, compris des 3 angles de 101 degrez chacun..." This was a part of point 5 to be found on page 95 of the Traité de la Lumière.

${ }^{70}$ OC, vol. 8, no. 2368 Christiaan to Constantijn, 22 September 1684, "Puis que le vostre vient de Lingen, on pourroit estre informè dans quels lieux et en quelle terre il croit ce qui merite d'estre sceu, sur tout pour moy qui ay escrit un traitè de ce cristal."

${ }^{71}$ Huygens, Traité de la Lumière, p. 91 "Il y a plusieurs corps vegetaux, mineraux, \& sels congelez, qui se forment avec de certains angles \& figures reguliers. Ainsi parmy les fleurs il y en a beaucoup, qui ont leurs feuilles disposées en polygones ordonnez, au nombre de 

GARDEN CAVES AND CABINETS

3.4.5. ou 6 costez, mais non pas d'avantage." and: p. 92 "Toutes ces choses meritent d'estre recherchées soingeusement, pour reconnoitre comment $\&$ par quel artifice la nature y opere. Mais ce n'est pas maintenant mon dessein de traite entierement cette matiere. Il semble qu'en general la regularité, qui se trouve dans ces productions, vient de l'arrangemét des petites particules invisibles \& egales dont elles sont composées."

${ }^{72}$ Ibid., p. 96, “Je n'entreprendray pas de rien dire touchant la maniere don't s'engendrent tant de petits corpuscules, tous égaux \& semblables, ni comment ils sont mis dans un si bel ordre. S'ils sont formez premierement, \& puis assemblez, ou s'ils se rangent ainsi en naissant, \& à mesure qu'ils sont produits, ce qui me paroit plus vrai-semblable. Il faudroit pour developper des veritez si cachées une connoissance de la nature bien plus grande que celle que nous avons."

${ }^{73}$ Both pre-press manuscripts are not included in the Oeuvres Complètes. 


\section{Chapter three}

\section{The Company's Garden and the (ex)change of nature and knowledge at Cape of Good Hope (1652-1700)*}

\section{Introduction}

The Dutch East India Company, the General Government at Batavia, and the Cape Government may be compared to three seas, each having a distinctive source, yet flowing into one another. Ebb and flow would constantly re-act upon them - from Holland to Batavia, and back from Batavia to Holland; from Holland to the Cape, and back from the Cape to Holland; from Batavia to the Cape and back again to Batavia - thus the tide would come and go. These seas must also be regarded as of great depth, but in surface area the one representing the Cape is very small in comparison to the rest, which, however, does not impede its tidal flow and reaction upon the other seas. ${ }^{1}$

Otto Mentzel, Glogau, 1787

With these words the German Otto Mentzel ended the first volume of his threevolume book on the Cape of Good Hope, having worked for the Dutch East India Company (VOC) in the Dutch colony between 1733 and 1741. He represented the three stations of the VOC as separate water courses that blended, transformed, and transported people, information and goods. Mentzel clearly saw the significance of the Cape colony as contributor to the vast VOC network. Indeed, the founding years of South Africa's colony underscore the existence and effect of a 'tidal flow' of the circulation of knowledge, people, and objects to and from the Cape and its hinterland. The VOC garden at the Cape (usually referred to as the Company's garden), in particular, functioned as a point of intersection where local knowledge, needs, and networks flowed into the global (trade) canals, to be brought to distant shores.

In 1652, the VOC began a refreshment station at Table Bay as part of its commercial expansion. ${ }^{2}$ [see picture 3.1] Here, passing ships revictualized while sailors regained their health. Fresh vegetables and fruits were grown in the Company's garden and the VOC bartered with the nomadic inhabitants of the Cape, the Khoikhoi, for cattle to provide them with meat and dairy products. The construction of the 


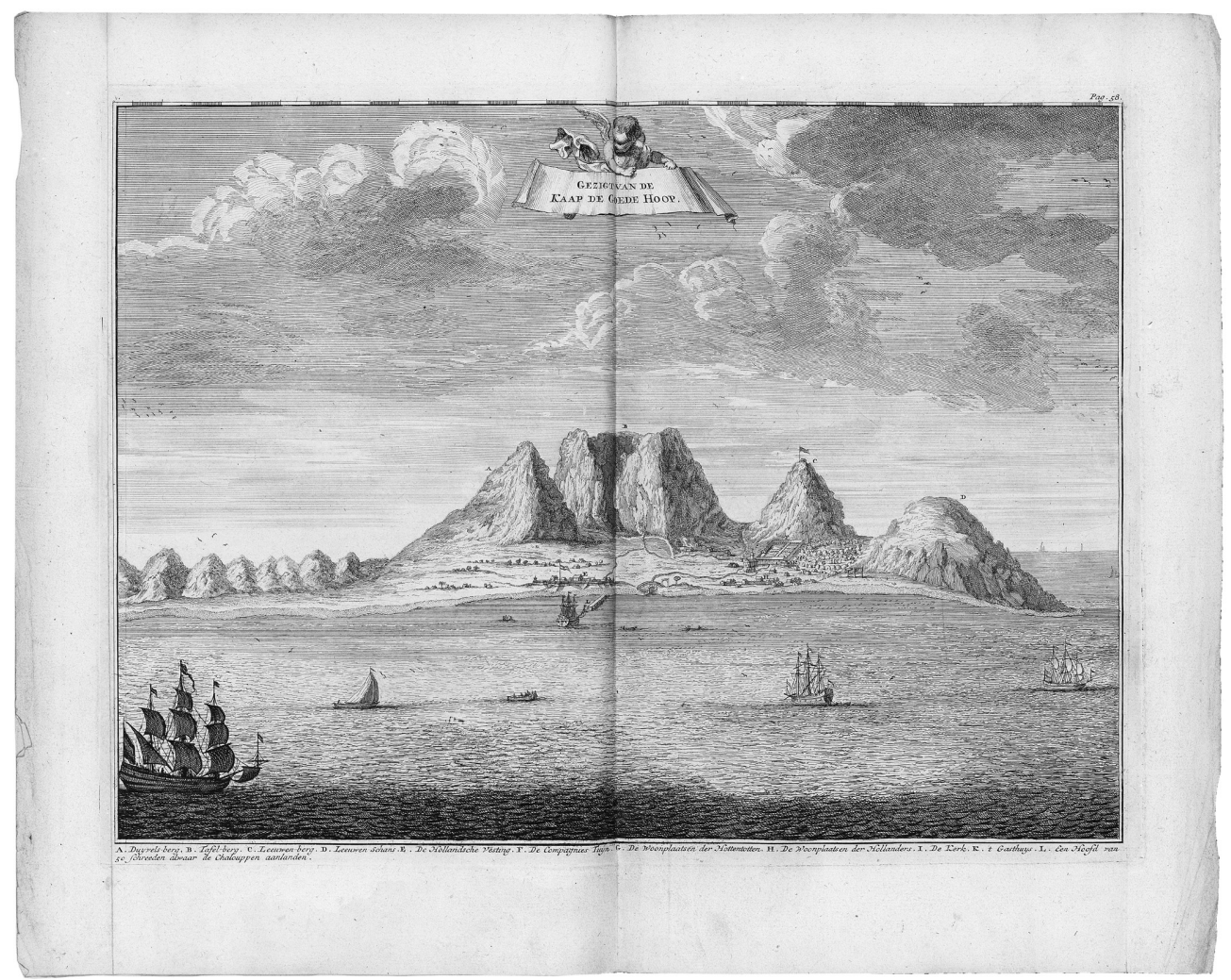

3.1) Peter Kolb, View on Cape of Good Hope, engraving in P. Kolb, Naaukeurige en uitvoerige beschryving van Kaap de Goede Hoop, (Amsterdam: Balthazar Lakeman, 1727), vol. 1, p 58. OTM OF 63-19, special collections, University Library Amsterdam, Amsterdam

colony entailed experimenting with local and imported plants and exploring the land in search of Khoikhoi merchandise and Cape minerals. The development of commerce and cultivation, in short, went hand in hand with a growing understanding of the Cape's natural and geographical knowledge. ${ }^{3}$

Examining the Company's garden and, subsequently, the Cape's agricultural settlement tell us how Dutch colonizers and merchants adapted and transformed South African nature. Broadening our scope, this allows us to consider the Cape Peninsula in its entirety as a garden, since uncultured nature was viewed as an invitation for settlers to claim these lands and transform them into a Dutch-European landscape yielding cereals, pastures, and vineyards. 'Gardening' untamed nature justified the colonization and transformation of the Cape. This essay thus discusses the Cape as a 
THE COMPANY'S GARDEN AND THE (EX)CHANGE OF NATURE AND KNOWLEDGE AT CAPE OF GOOD HOPE (1652-1700)

site where gardening transformed the local landscape as well as its native and foreign inhabitants. Both settlers and Khoikhoi adapted to the changing circumstances, appropriating knowledge and practices of the 'other' and merging the unfamiliar with what was already known and practiced. This inventive fusion took place with the aid of local go-betweens who mediated between Khoikhoi and Dutch. The agricultural enterprise of the Dutch blossomed, the Company's local presence and global network strengthened while that of the Khoikhoi increasingly weakened, gradually becoming disconnected from their nomadic ways and their pastures. ${ }^{4}$

Through its extensive communication system, which afforded both the local and long-distance accumulation of (embodied) knowledge, the VOC tried to stimulate and control this process. To further their commercial goals, the Company demanded regular shipments of geographical and natural knowledge and objects, while simultaneously prohibiting the disclosure of these secrets to others. Historian of science Klaas van Berkel signals this cautious attitude in his article on the VOC by considering the company as a reluctant patron of natural knowledge. Rather than analyze the production of natural knowledge as an integrated aspect of VOC activities, however, Van Berkel separates out and focuses specifically on the "natural scientific researches' undertaken by VOC men in their spare time, such as Hendrik Adriaan van Reede tot Drakenstein and his Hortus Malabaricus and Georg Eberhard Rumphius and his work on the natural history of Ambon. What he thereby underestimates is how the production of natural knowledge and the VOC's commercial interests actually depended on each other, something that is not at all contradicted by his observation that the VOC in Amsterdam controlled the circulation of findings and kept natural secrets from their mercantile rivals by withholding manuscripts from publication. If we accept that the commercial goals of the VOC stimulated as well as fed off the accumulation of (local) natural knowledge, goods, and oral information, we can identify a constant flow of knowledge and practices moving between various cultures. ${ }^{5}$

Reluctant or not, with or without the VOC's consent, people, objects, and information interactively gathered at the Company's garden. This garden became a middle ground where these interactions took place. ${ }^{6}$ In the early years, the accumulation and dispersion of natural knowledge and practices between Khoikhoi and colonizers was a mundane reality of everyday life, facilitated by local mediators. Following Mentzel's water metaphor, the accumulating knowledge and practices flowed from one cultural location to the other, transforming in the process of making their way to both a European 'scientific centre' and to the minds and hands of the Khoikhoi peoples. At the Cape, the Company's garden became a 'centre of accumulation' for the VOC and a site through which both cultures encountered and appropriated previously unknown knowledge and practices. ${ }^{7}$ 
Both Western and Khoikhoi networks followed their set paths of demand and supply of information and goods which each tried to contain and transport to other areas for further observation and distribution. A constant production of charts, reports, drawings, herbals, seeds, and other samples flowed from the Cape to the VOC centres in Amsterdam and Batavia. The Khoikhoi likewise amassed information and practices from the Dutch, which they dispersed for other African peoples to become acquainted with. Befitting their nomadic lifestyle they circulated knowledge orally or embodied it in objects and ways of doing which travelled with them.

This essay begins by introducing the original inhabitants of the Cape region, their knowledge and practices. ${ }^{8}$ Then follows an examination of the start of the Cape settlement, how the Dutch settlers commenced their gardening practices and brought progressively more land under cultivation, against which the natives protested. The next section discusses the different ways to establish and maintain a middle ground, to use Richard White's helpful term, in which European settlers and the Cape's indigenous peoples developed means of communication and enlisted intermediaries in order to negotiate trade and exchange information. Lastly, the conclusion brings these sections together and critically reflects on the culturally laden portrayal of civilized Europeans bringing (agri)culture to 'ignorant' natives which continues to persist and recounts how intermediaries enabled the accumulation of local information and objects which were transformed so that distant 'others' could become familiar with the unknown while trying to strengthen their position.

\section{The Khoikhoi}

Various nomadic peoples roamed along Table Bay, following the Cape of Good Hope and trekking inward from South Africa's coast, including the hunter-gatherers San and the herdsmen Khoikhoi. These horizontally organized nomads lived in different clans of several hundred to a few thousand people, with one person per group functioning as leader. The Dutch labelled this person 'captain' giving him a stick with a copper badge with the VOC logo. This staff symbolized the trade ties between the Dutch and the locals, while making the 'captain' a recognizable figure for both natives and newcomers as main negotiator of goods and knowledge. [see picture 3.2]

The Khoikhoi regularly trekked across the land searching for fresh pastures and water. They took into account the alternating dry and wet seasons, whereby experience and examination helped to determine the location, availability, and quality of fresh water, grasslands, and useful plants. The Khoikhoi returned to the same spot perhaps once a year, depending on the weather conditions. They lived for "the most part on beef, mutton, all sorts of game, and other flesh that suits their taste, well roasted or boiled [and] on wild fruits and roots, and other unpurchased victuals" as 
THE COMPANY'S GARDEN AND THE (EX)CHANGE OF NATURE AND KNOWLEDGE AT CAPE OF

GOOD HOPE (1652-1700)

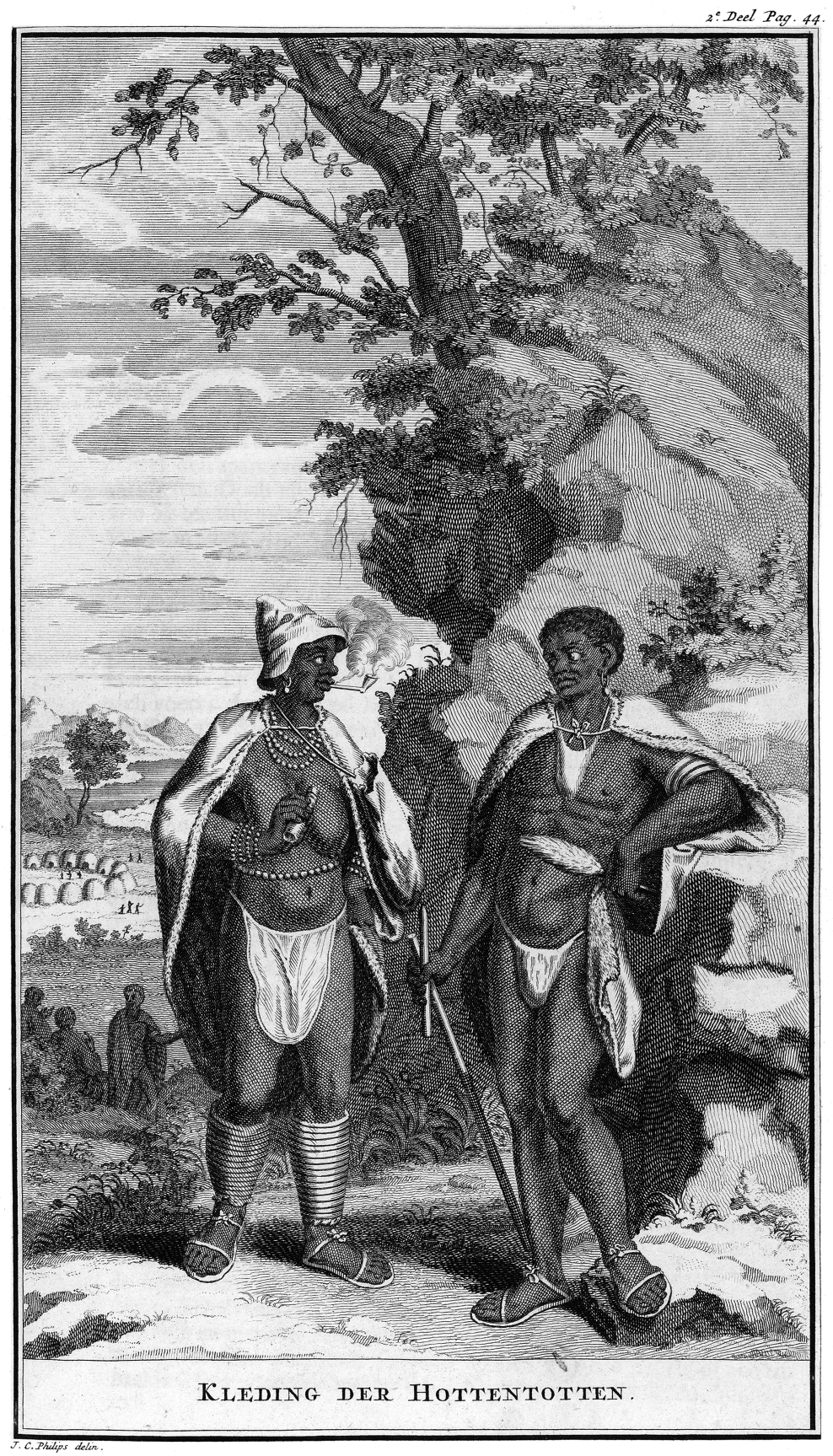

3.2) Peter Kolb, The Hottentots and their dress, engraving in P. Kolb, Naaukeurige en uitvoerige beschryving van Kaap de Goede Hoop, (Amsterdam: Balthazar Lakeman, 1727), vol. 2, p. 44. OTM OF 63-20, special collections University Library Amsterdam, Amsterdam 
THE COMPANY'S GARDEN AND THE (EX)CHANGE OF NATURE AND KNOWLEDGE AT CAPE OF GOOD HOPE (1652-1700)

the Dutchman Johannes Grevenbroek mentioned in his journal. According to the well-informed armchair traveller Olfert Dapper the men herded and hunted whilst the women searched for "certain type of round roots vegetables" along the riverbanks and other sites, which they "eat either boiled or fried, according to taste."

The natives possessed knowledge of medicinal plants and ways to make cures. They had ointments against bruises and treatments against bites of poisonous animals and insects. According to the Dutch traveller Willem ten Rhyne, they cured "colic quickly by [using] a certain aromatic root." For sick people the women would prepare a mixture of "cabbage, mallow, and mustard leaves, cooked with a little stamped blubber." Various types of the mallow plant could be found along Table Bay, which was used as a treatment against "respiratory diseases, coughs and internal aches, as stimulants or purgatives, to soothing wounds and cuts." The women had acquired knowledge of medicinal plants, of preparation, and dosage to cure their sick and wounded that they handed down from one generation to the next. Likewise, the men knew which toxic plant parts to prepare as poison. With these concoctions they would treat arrowheads and the tips of assegais that would kill an animal "the day after the wound." These activities suggest a deep familiarity with natural knowledge achieved through experiment and observation. ${ }^{10}$

Some contemporary sources acknowledged that the Khoikhoi possessed knowledge of the Cape's nature and that they knew how to manage and manipulate it. The German VOC employer Johann Wilhelm Vogel described that when the grass

is so high that it comes up to one's knees, and, when it is too old and tough to be eaten by the beasts any more, it is set on fire by the inhabitants, so that at times it is to be seen burning for several miles. But in order that the fire may go no further than the inhabitants wish, they dig out a trench, where the fire decreases and dies out when it reaches it, for lack of more near-by grass to feed it. The ashes of such burnt grass manure the land where the fire was, and make it so fertile that, when light rains fall, in a short time new or young grass grows up, into which the animals are driven to graze; and thus in one region after another where the grass has become too old, it is thus renewed by the operation of burning it.

The Khoikhoi knew when and how to regenerate nature and they knew how to constrain these grass fires. The Dutch later copied this custom, noted the German VOC servant Peter Kolb, after "having seen, learned and approved of it." The Dutch, however, transformed this process of the nomads by adapting it to the needs of European-style agriculture. ${ }^{11}$ 
THE COMPANY'S GARDEN AND THE (EX)CHANGE OF NATURE AND KNOWLEDGE AT CAPE OF GOOD HOPE (1652-1700)

The Khoikhoi used their knowledge of the landscape and the position of the stars to find their way to fresh pastures, water sources, and to other roaming groups. Their trade routes led to the lands of the Xhosa all the way in the east, and probably across the Orange River in the north to Bantu-speaking areas. These groups exchanged information, arranged marriages, and traded cattle for luxury items (metal and herbs). This trade, as historian Richard Elphick remarks "was not of sufficient scale to alter fundamentally the Khoikhoi economy or political structure." These pastoral people did not create a market, a merchant class, nor did they obtain "such large accumulations of nonpastoral wealth that previously existing differences between rich and poor, or between ruler and ruled, were markedly intensified." 12

Their nomadic lifestyle did not allow for excess accumulation of wealth or endless accumulation of goods and (non-portable) knowledge; a person with cattle was wealthy and someone without cattle was poor. This non-scriptural society carried their worldly goods on their oxen and their backs, and their knowledge of the environment in their hands and minds. Accumulation beyond a certain point was not manageable, since it could not be contained and transported via known means. What the natives required for nourishment was found while trekking across the land. They circulated with their knowledge of the land and nature from one pasture to next. This meant that they did not process, relocate, store or accumulate food and water supplies in one fixed site, which they could use in times of need. The only surplus they created was of their cattle and sheep, which they considered a sign of wealth rather then a commodity. ${ }^{13}$

Given their nomadic existence, the Khoikhoi did not need to put in extra work-effort (to collect vegetables or dairy products) to create a surplus. In keeping with this, there was no need for a paper administration or a written language. Interpreting this as a significant cultural marker, Olfert Dapper described the Cape natives as "bereft of all science and literature, very uncouth, and in intellect more like beasts than men." Westerners valued, and still do value, the written word over oral information. The nomads, however, actively acquired knowledge and goods that they subsequently transported, traded, and transformed.

With the arrival of the Dutch, the Khoikhoi groupings adapted to the new circumstances and found ways to deal with the Western settlers. One of the first steps the natives took was to learn Western languages. Dapper signalled that some Khoikhoi "through steady intercourse with our countrymen, gradually let the sparks of their human nature come to light, just as several at the Fort are also beginning to grasp the Dutch language." 14

These nomads, in the eyes of the Westerners, did not undertake any recognizable agricultural activities other than herding beasts, which were kept primarily for their 
dairy products and not so much for their meat. They did not live in fixed houses, nor cultivate the land. And when the colonizers copied the natives' way of grass burning, for example, it was not accompanied by an acknowledgement that the natives' agricultural knowledge was worth adopting. Dutch settlers neither acknowledged Khoikhoi knowledge and practices, nor the natives' notion on ownership and habitation of the lands..$^{15}$

Christian sentiments regarding the cultivation of one's garden as well as the notion that the Western way of commerce and agriculture were superior to those of the nomads undergirded Dutch disparagement of Khoikhoi knowledge. This allowed the VOC to propagate the claim that the Cape was 'vacant' of agriculture and settlements, which justified their colonization and further exploration of the land. To validate their settled ownership and cultivation of the land, the Dutch emphasized the Khoikhoi's lack of culture and agriculture. With the plough and surveying instruments in one hand and deeds of acquisition in the other, Europeans changed the Cape's landscape. This contributed to a centuries-long presumption regarding how the West cultivated the under-developed 'Rest' while the Dutch in fact profitably absorbed Khoikhoi knowledge and practices. ${ }^{16}$

\section{The start of the settlement}

In 1652, Commander Jan van Riebeeck landed at Table Bay to set up a refreshment station. Previously passing Portuguese, English, and Dutch ships had used this natural harbour to collect fresh water and barter food with the natives. Riebeeck's small fleet of three ships carried the necessary goods to start a settlement, such as materials to build houses, furniture, utensils, and various garden seeds and bulbs. Armed with a limited knowledge of the Cape but with their agricultural skills, the first group stepped ashore, where they began 'improving' the Cape's nature. The settlers started to change what they viewed as an untidy landscape into an orderly, well-maintained and productive garden, while organizing a steady water flow by digging basins and canals. ${ }^{17}$

Every step of this transformation was reported to the VOC directors in The Netherlands who demanded regular reports with information on the local geography, climate, types of soil, rivers, fish, plants, animals, mountains, and samples of its natural riches. Expeditions provided further charts and information about the Cape's elevation, orientations, soils, and water supply, as well as descriptions and drawings of plants and animals. It was essential for this long-distance corporation to receive the latest geographical and natural information and samples to further their mercantile goals. The Company stretched its tentacles out as far as possible, reeling in information that was rendered stable in charts, drawings, and reports. From a distance, the 
THE COMPANY'S GARDEN AND THE (EX)CHANGE OF NATURE AND KNOWLEDGE AT CAPE OF GOOD HOPE (1652-1700)

board of directors tried to manage the process through rules and regulation on how to deal with native peoples in order not to damage trade and negotiations regarding land and information. ${ }^{18}$

The first locals the Dutch encountered along Table Bay were the Goringhaico$n a$ (renamed 'beach rangers' by the Dutch). They were cattle-less hunter/gatherers roaming along the coast. From circa 1600, this group had become familiar with European trade goods such as copper, iron, alcohol, and tobacco, from their encounters with recurrent Portuguese, English, and Dutch East Indiamen. These items were handed out as tokens of friendship and exchanged for food, firewood, assistance, and information, which they, in turn, used as currency to barter for cattle with trekking Khoikhoi. Seen from the native standpoint, these passing European tradesmen were like them: a mobile people who periodically returned to the same spot for water and food and then moved on to the next site. When the Cape natives realised that Riebeeck's group wanted to stay at Table Bay this notion of a nomadic European counterpart changed dramatically. At first however the Dutch did not meet with much hostility while commencing with their agricultural enterprise. ${ }^{19}$

Sailors and soldiers with a background as gardeners or farmers, and with handicraft knowledge were put to work by the VOC in and around the Fortress and the Company's Garden. This 'motley crew' of Europeans had left behind their homes and families to join the VOC. The group consisted of those who sought to escape poverty in search for fortune and those who were tricked by 'soul merchants' to sign up with the VOC either as sailor or soldier in exchange for ready cash. Some of them left from Amsterdam with their wives and children to start a new life elsewhere for good. This group merged into a workforce that constructed the settlement and the Cape garden. At the Cape, they prepared the soil by clearing it of weeds, shrubs, and rock since the land "was covered with thick growing, shrubby plants of various heather types and proteas." 20

Johan Schreyer, a German in the service of the VOC, commented in 1668 that the Cape was "all uncultivated and uncleared, just as it was made at God's Creation. And I assert, that if there were folk to cultivate, plant and inhabit this fallow land, better ground would be found here than in all Europe." To transform this land, the settlers started by staking out a terrain of circa forty-two acres close to the Fort, and dividing it by paths and irrigation canals into rectangular sections. This was to become the Company garden; a testing ground of seeds, roots, and plants, not only from and to Holland and Batavia, but shipped directly from all parts of the world, through the extensive Dutch commercial network. ${ }^{21}$ [see picture 3.3]

Arriving with the Commander was Hendrik Boom, who became the first head gardener at the Cape and who, according the VOC lists, had previously worked in Amsterdam as a gardener. Boom had brought vegetable and herb seeds from Hol- 


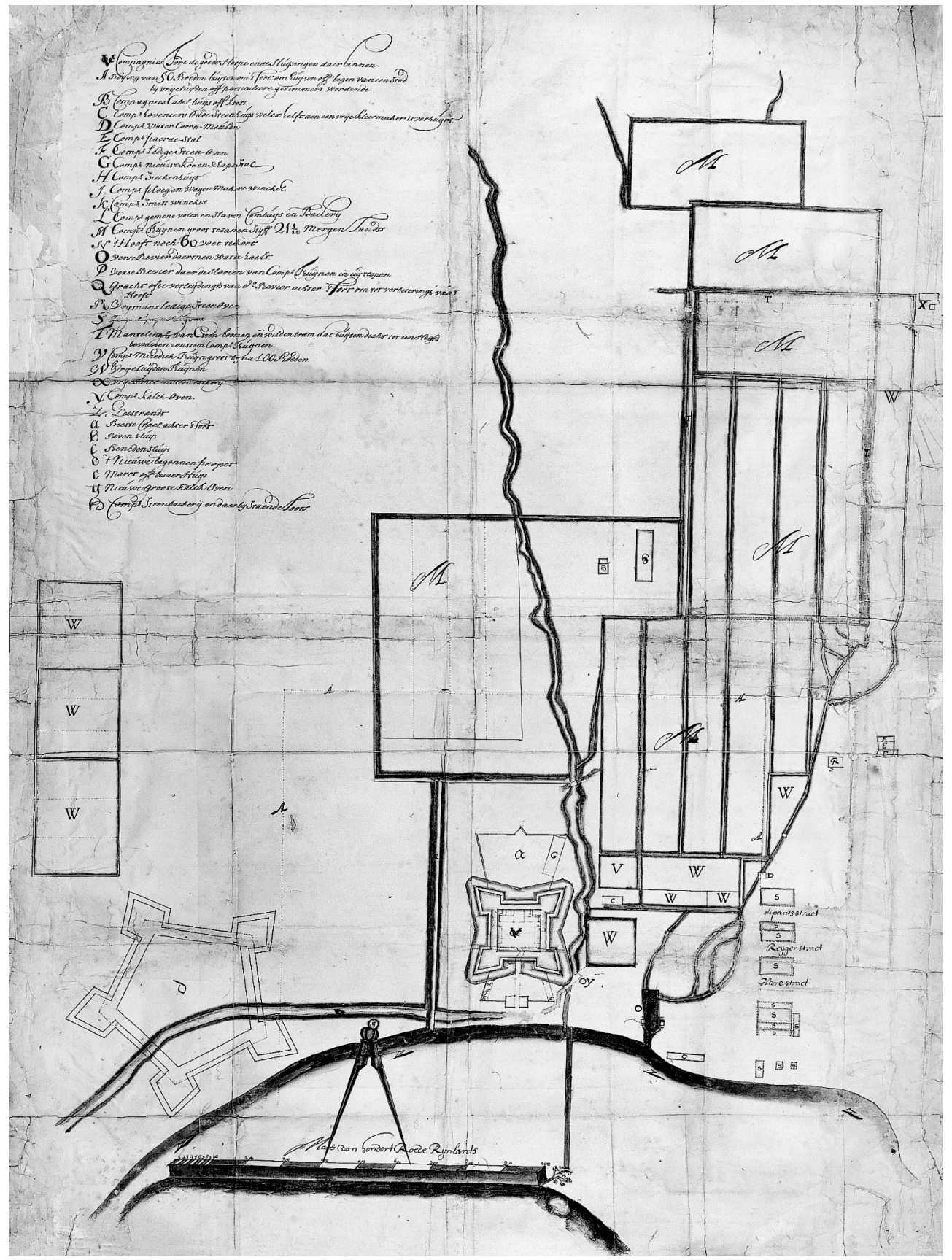

3.3) Pieter Potter, Map of the Company's garden and fortress, circa 1665, 4.VEL 825, Nationaal Archief, Den Haag 
THE COMPANY'S GARDEN AND THE (EX)CHANGE OF NATURE AND KNOWLEDGE AT CAPE OF GOOD HOPE (1652-1700)

land, which he sowed in the newly constructed Company's garden. But the garden soon became a global centre of experimentation and accumulation, as he received seeds, roots, and plants, not only from Holland and Batavia, but directly shipped from all parts of the world, through the VOC's extensive commercial network. The gardener planted cabbages, carrots, and "other root vegetables," rosemary and laurel, cereals, apples, pears, and grapes from Europe. From the Americas and Indies he grew pineapples, sweet potatoes, calabash, cucumbers, Indian radish, banana, peanuts, "and all other imaginable seeds..." In January 1653, skipper Teunis Eyssen from the galliot Swarte Vos passed Pernambuco (Brazil) and brought "some Brazil pumpkin, melon and watermelon seeds [which were] already sprouting beautifully." From the Far East came various plants such as banana and guava. Tea and camphor were brought from Japan and Batavia by the German gardener and VOC employee George Meister to the Cape where the plants rested for a period of time before being transported to Amsterdam. A single camphor tree remained behind in the medicinal section of the Company's Garden. ${ }^{22}$

This centre of accumulation showcased the orderliness as well as the wealth and might of Dutch enterprise while simultaneously feeding hungry settlers and sailors. In this sense, the garden can be compared to a laboratory or modern factory in which local conditions are minimized as much as possible, in favour of constructing a standardized environment in which the same results can be achieved as in any other such space, regardless of the actual geographical setting. By recontouring the ground along geometrical lines and planting it with seeds drawn from elsewhere, VOC gardeners sectioned off a part of nature. They changed this portion of the original landscape into a cultured environment in order to nurture the global network of which it was now an integrated node..$^{23}$

The Dutch put a great deal of effort into making these cultivating experiments a success. But hunger loomed. In the first years, imported saplings were washed away by the May rains. Harvests were destroyed by the dry south-eastern winds, and seeds failed to grow because of unfit circumstances. Boom planted a screen of trees to protect his vegetation against wind. To control the water flow, he constructed a system of canals that enabled him to irrigate the garden during the dry season. This stood in opposition to the farming practices in the Low Countries where ditches relieved gardens and farmlands from excess water. The gardener redirected water from a stream further uphill into straight canals reaching every part of the garden. The Dutch transformed the familiar overflow canal into an indispensable irrigation system at the Cape. They adapted to the new circumstances, that is to say, by changing their land management and agricultural practices to meet local requirements. ${ }^{24}$ [see picture 3.4] 
THE COMPANY'S GARDEN AND THE (EX)CHANGE OF NATURE AND KNOWLEDGE AT CAPE OF GOOD HOPE (1652-1700)

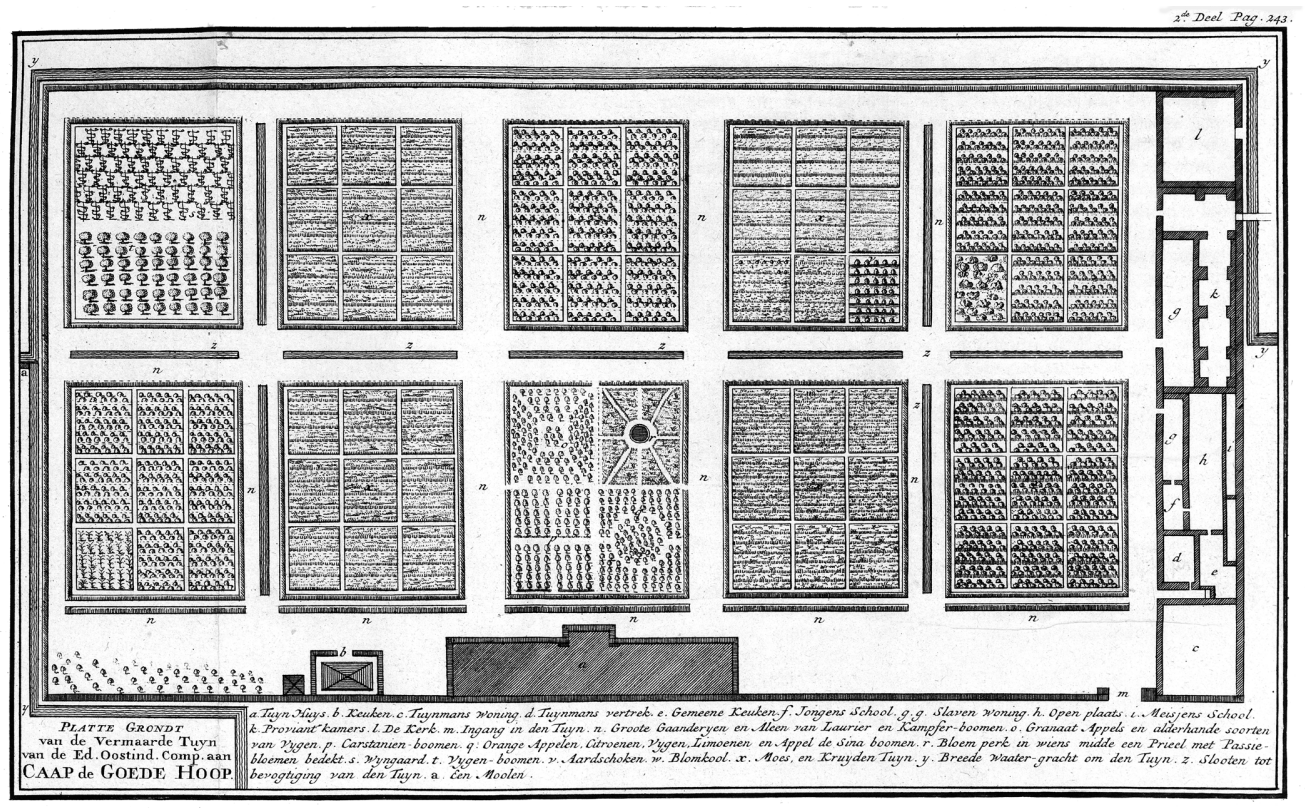

3.4) Peter Kolb, The Company Garden, engraving in P. Kolb, Naaukeurige en uitvoerige beschryving van Kaap de Goede Hoop, (Amsterdam: Balthazar Lakeman, 1727), vol. 2, p. 243. OTM OF 63-20, special collections University Library Amsterdam, Amsterdam

Meanwhile, the colonizers learned to prepare and eat local plants and avoid scurvy or starvation. Boom, while planting wild asparagus, sorrel, wild leek, and a type of mustard seed, simultaneously contributed to the VOC's constant demand for information by inquiry into local vegetables and herbs. The natives had informed Boom or his garden helpers about the edibility of the wild asparagus (also known as the hotnotskool) which was widely eaten by the natives. The Khoikhoi furthermore showed the Dutch how to cook bitter almonds, which Riebeeck said he would try at his earliest convenience. But the gardeners were more interested in the thickly foliaged evergreen shrubs that bore these almonds, as a protective hedge around the gardens against animal and human intruders. The Commander gathered the information on various nutritious Cape plants, but it seemed that the settlers only occasionally adapted their palate to Khoikhoi cuisine. They adopted the wild asparagus into their diet, whereas the bitter almond entered their gardens for protective purposes. At the Cape, VOC-servants took over local knowledge and transformed it to suit their requirements. ${ }^{25}$

Over time, ever larger parts of the Cape became cultivated and colonized, fenced in to guard it against human and animal intruders. The aim of these new gardens was to feed settlers, soldiers, and sailors. The oldest Company's garden in the meantime 
THE COMPANY'S GARDEN AND THE (EX)CHANGE OF NATURE AND KNOWLEDGE AT CAPE OF GOOD HOPE (1652-1700)

was being transformed from a kitchen garden into a botanical garden, filled with both ornamental and useful plants from various parts of the world. It lost its primary victualizing function as the yields of settling farmers and of other gardens increased. Commerce and cultivation motivated the VOC to transform the Cape's environment, turning more and more land into gardens, and replacing local plants with imported vegetables and fruits. Pursuing agriculture was a way for the Dutch to understand, possess, transform and exploit the Cape's geography and nature. ${ }^{26}$

To make the settlement self-supporting, the Commander explored the possibilities of bringing other areas which were farther away from the fortress under the plough. Near Devil's Mountain a garden of about eight acres appeared; at the foot of Lion's Mountain a plot of land which was shielded from the wind was prepared for the growth of delicate ground-fruits and fruit-trees. A bit farther away, at Rondebosch, was "the Company's cornfield and orchard, where experiments were carried out with various plants, European and Indian, with widely divergent results." During the first decades the Cape Commander ordered surveyors to draw up maps of the whole pen-

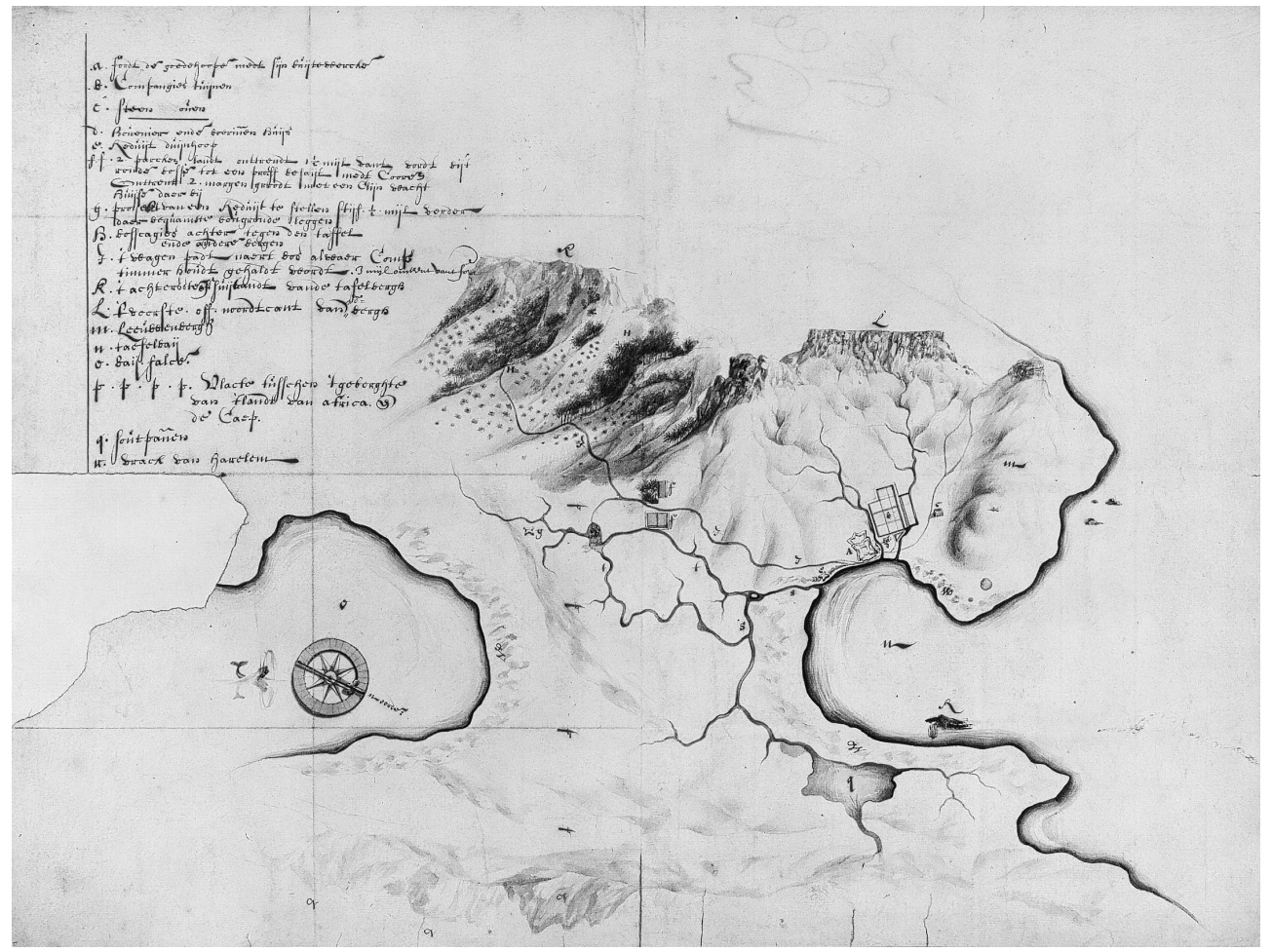

3.5) Anon., Map of Cape of Good Hope with trial farmlands with sowed corn, circa 1656, 4.VEL 803, Nationaal Archief, Den Haag 
THE COMPANY'S GARDEN AND THE (EX)CHANGE OF NATURE AND KNOWLEDGE AT CAPE OF GOOD HOPE (1652-1700)

insula with information on elevation, water sources, and types of soil. Helmsmen executed the surveyor tasks, since they were trained in and responsible for map making and triangulation on board ship. Aided by an ongoing influx of skilful sailors and soldiers, the VOC was able to rule the waves and cultivate the Cape. ${ }^{27}$ [see picture 3.5]

One of the early maps shows the settlement, the fortress, the Company garden and, at a short distance from the community, the planned agricultural development. The map projects a landscape with familiar elements and symbols (houses, gardens, rivers, trees) understandable to the Western viewer. The mapmaker left out any sign that indicated indigenous existence. He did not mark, for instance, the lands that the nomads used as pastures for their cattle. Thereby he created the image of a de-nativized space, suitable for cultivation and exploitation. These sorts of representations propagated the 'vacant land' myth as they did not show evidence of native habitation. Land surveying, therefore, was one step toward subjugating this perceived wilderness to the rules of geometry. Another step was the plough, which implemented the geometric rule by turning the land into straight furrows. On the cleared and prepared rectangular terrains, the settlers could sow, plant, and fence the terrain and construct housing and sheds. ${ }^{28}$

A farming frontier, which started small and existed at first only in words and charts, became a growing reality that pushed further inland. This conquest hit the Khoikhoi hard. On returning to their peninsular pastures, sometimes after a period of absence of one or even two years, the nomads saw their land changed into plantations and vineyards, fenced off and well-guarded against animal and human intruders. Khoikhoi pastures and water sources had been claimed in the name of the VOC, since nobody before had cultivated this 'wilderness'.

In spite of the Khoikhoi's recurring raids and protests against the ongoing agricultural subjugation the Company forced them to move to other pastures, based on the argument that they were not fixed to one place. In so doing the land- and cattle-hungry settlers redirected the natives to inferior grounds. As several historians, including Elphick, Guelke, and Shell, argue, the Khoikhoi were no match for the Dutch hunger for land. The nomads were too scattered over a large territory to act in union against the agriculturalists. In the end their arrows and assegais could not chase away the mounted soldier-settlers and their firearms. ${ }^{29}$

The Dutch obtained a firm grip on the land and the cattle trade by herding cows and sheep themselves, for which they had previously bartered copper and tobacco with the Khoikhoi. Herding large numbers of cattle put even more pressure on the available grassland and water sources. Along the peninsula groups of nomads trekked to other, more barren, regions in search of pastures, food, and water. Here, they struggled to maintain their former nomadic lifestyle, choosing between roaming 
THE COMPANY'S GARDEN AND THE (EX)CHANGE OF NATURE AND KNOWLEDGE AT CAPE OF GOOD HOPE (1652-1700)

even deeper inland, or adapting to colonial farming and work for the Dutch farmers as poorly paid cowhands and housemaids. The colonizers firmly consolidated their presence along Table Bay and progressively moved further inland. Over time, the Dutch increasingly pressured the local inhabitants to give up their nomadic lifestyle. As illustrated by a map of 1692, mapmakers were now prepared to include the natives in their charts. The map representationally transformed the Khoikhoi's mobile shelters into groups of neat circles, thereby fixing them at the periphery, far removed from their old pastures and water sources. The cultivated sections were marked with their Dutch names, thereby firmly establishing the new rule. [see picture 3.6]

Giving a territory a name was one way of knowing or owning the land. Descriptive labels provided information about the layout of a landscape so that others could become familiar with its geography and inhabitants. In a way the settlers entered the Cape like a worldly Adam, naming places, plants, and people. To incorporate the peninsula into Western culture, the settlers gave Dutch names to the encountered landmarks, which appeared on the newly made maps. VOC employees 'christened' the landscape, making it part of the VOC's growing realm. ${ }^{30}$

The Dutch gave names to land marks based on their characteristics or shapes, or to remind them of their homeland. The colonizers, for instance, named the Orange River in commemoration of their Stadholder, the Prince of Orange. In some cases both local and Dutch names were recorded. Boom's successor Jan Hartog copied both Khoikhoi and Dutch names in his journal of the 1707 expedition into the hinterland. He renamed the river Koutema the Palmiet River for the palm trees growing nearby and the Doggha kamma became Swarte (Black) River. Although the Dutch could not reproduce the Khoikhoi clicks and other sounds in writing, these names helped the Commander and the native interpreters at the Cape to retrace the expedition's footsteps, together with newly compiled maps. This collection of charted knowledge was furthered to the VOC headquarters in The Netherlands, making the unfamiliar geography of a distant district understandable, and manageable. ${ }^{31}$

Incorporating the Cape's landscape into the Dutch realm enabled the VOC to explore and exploit it for the benefit of the settlers, the passing East Indiamen, and for those at home. The settlers, however, needed the help and cooperation of the local inhabitants to further their commercial enterprise. Instructions from the VOC board were clear: the Dutch had to befriend the natives in order to exchange tobacco, alcohol, and copper for food (mainly cattle) and information.

It could be difficult for the newcomers to trade with the roaming Khoikhoi and their herds, since they were not always close to the Cape when needed. The cattleless 'beach rangers' first helped the Dutch by mediating the cattle trade and establishing contact with these herdsmen. A little later a young Khoikhoi woman became 


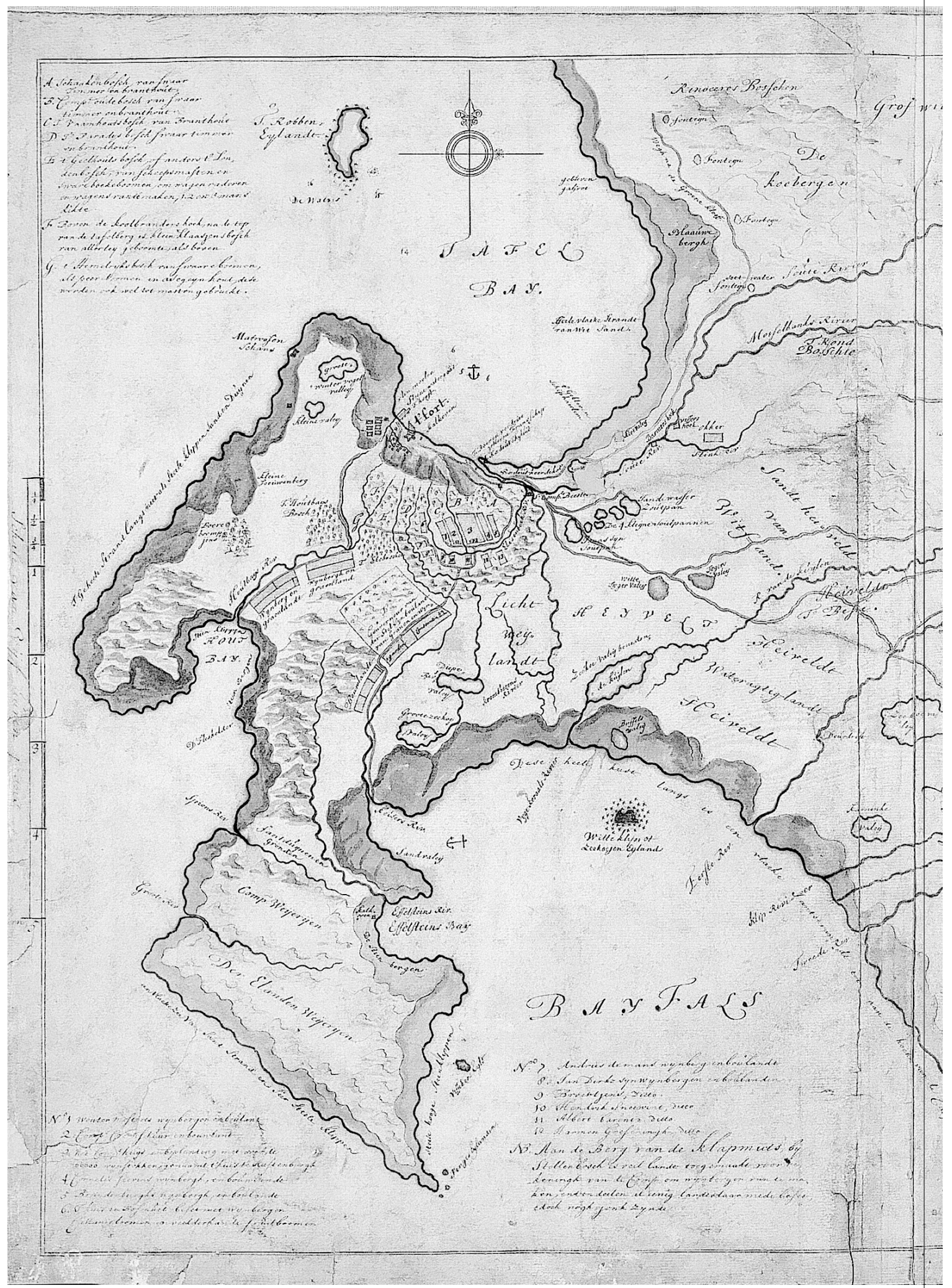

3.6) Isaac de Graaff, Map of Cape of Good Hope, circa 1695, 4.VEL 809, Nationaal Archief, Den Haag 


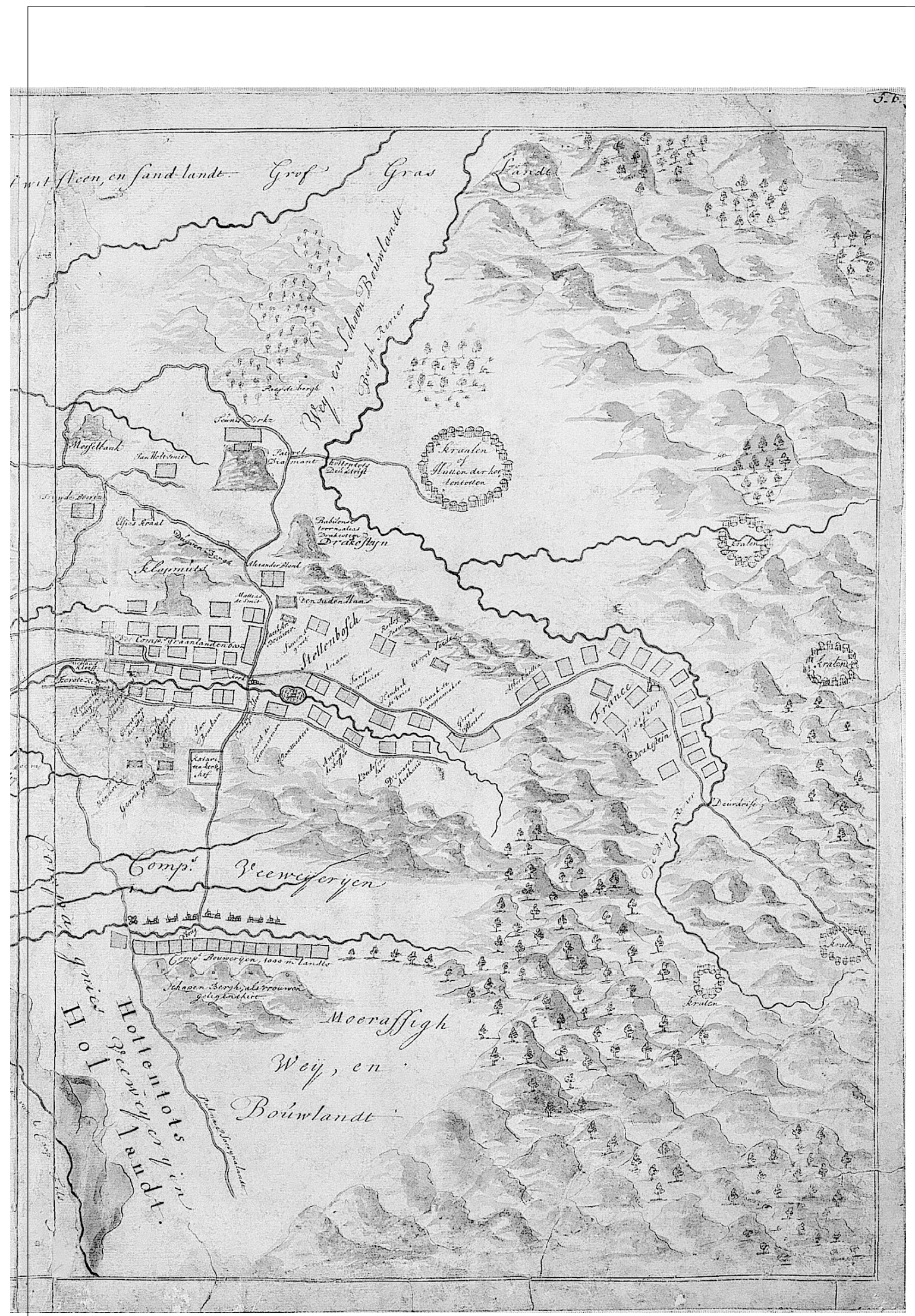


the main mediator for negotiating the exchange of Dutch goods for cattle and information, thanks to having learned to speak Dutch while living with the Riebeeck family. This go-between temporarily bridged the gap between the two opposing cultures, each of which considered the other as alien, suspect, and threatening.

\section{The middle ground}

The strangeness of the 'other', their unfamiliar ways and practices, together with the language barrier, allowed for a mutual distrust between natives and settlers. This distrust stood in the way of bartering goods and acquiring information. However, the Dutch needed the local products and knowledge for their survival whereas the Khoikhoi desired the proposed Western goods. Both parties were willing to come together to negotiate prices in exchange for the other party's offered valuables (copper, cattle, information, etc). By doing so they created a middle ground where they established communication and rules of exchange.

In his book The Middle Ground; Indians, Empires, and Republics in the Great Lakes Region, 1650-1815 historian Richard White develops the concept of a middle ground, which enables him to explore and explain the interactions between French and Algonquin Indians in the Great Lakes region of North America. White clarifies that a middle ground allows one group to achieve the cooperation or consent of others without using force. The creators of the middle ground, he argues, justify their actions according to what they perceive "to be their partner's cultural premises," while convincing the 'other' that the mutual action is fair and legitimate. The presence of a mediator makes the formation of a middle ground possible through the constitution of a communal language and/or signs. Through these tools trade is negotiated, information exchanged, and certain rights and practices explained. To explore this at the Cape, the first part of this section discusses the challenges of establishing and maintaining a middle ground due to a limited vocabulary paired with cultural difference regarding property, which led to a confusion of use and interpretation of words. The second part introduces the young Khoikhoi woman Krotoa - also known as Eva - who functioned as a mediator between the Dutch and the Khoikhoi. ${ }^{32}$

As mentioned, the first Khoikhoi the colonizers encountered around Table Bay were the so-called beach-rangers. These hunter-gatherers had traded regularly with passing sailing ships and had over time acquired some Portuguese, Spanish, English and Dutch words. With them the Dutch established a communal language based on this existing but limited vocabulary. Over time, the VOC employee Johannes Grevenbroek signalled that natives had acquired "a good speaking knowledge of Dutch." He advised the settlers to do the same and learn Khoikhoi, since they "ought 
THE COMPANY'S GARDEN AND THE (EX)CHANGE OF NATURE AND KNOWLEDGE AT CAPE OF GOOD HOPE (1652-1700)

to be aware how firm a bond of union a common language is, and how powerful a means it is of keeping peoples loyal and peaceful." ${ }^{33}$ The beach-rangers' basic knowledge of European idiom enabled the creation of a middle ground that allowed for the exchange of cattle versus copper. At the same time this feeble verbal base led to mutual misunderstanding and furthered distrust.

One example illustrates the difficulties that attended this situation. When a group of Khoikhoi encountered a few Dutchmen in search for cattle, the natives used their limited knowledge of Dutch and its culture to express their right over a certain territory. The natives attempted make the settlers understand that they had strayed into land which the Khoikhoi used as pasture. According to the colonizers who reported the incidence, they explained that the land was their Holland, calling it 'Hottentots Holland'. This eventually led to a creative (mis)interpretation by the Dutch, who understood this land to be as lush as Holland itself. Both cultural differences and language difficulties made it problematic for the Khoikhoi and the Dutch to pass on information regarding this territory.

The name Hottentots Holland began to appear on maps and in reports. In March 1670 , Riebeeck informed the VOC that "circa twelve hours from the fort lies a certain site named Hottentots Holland of about 2,000 morgen with extremely good land." The agriculturalists were "unanimous in their decision" to put it under the plough, the cultivation of Hottentots Holland would benefit the settlement and the Company's ships. The name's significance thus shifted from underpinning the Khoikhoi's claim to (purportedly) indicating its agricultural potential. Introducing this name to the VOC board suggested that this land was as fertile as Holland, thereby giving priority to 'Holland' as a defining category that transcended the local, fixed geography. In his resolution Riebeeck failed to mention that the natives had claimed this land. He asserted it to be empty, erasing them verbally from their pasture. In December 1671, the Commander ordered a land surveyor to "inspect the situation and the cultivation of the lands," and make a map for the VOC head-office. Both in words and in drawings, Hottentots Holland fell in the hands of the Dutch. The subsequent misinterpretations or mistranslations enabled the Dutch to further their agricultural goals. ${ }^{34}$

Not only did the Dutch possess a larger network and more ways of transporting information, the roaming herdsmen were not always present to oversee the grounds that the nomads experienced and sought to express as their pastures. The colonizers used the Khoikhoi's lack of consistent presence, either embodied in maps and decrees, or buildings and agriculture, to strengthen their position and enlarge their settlement. The middle ground which the Khoikhoi originally helped establish was washed away by the tidal waves of the Dutch mercantile and knowledge network, and 'validated' by a growing accumulation of charts, reports, and deeds. ${ }^{35}$ 
Learning a foreign language made communication possible while initially giving the natives a certain advantage in negotiations, since the Dutch could not understand what the Khoikhoi said amongst themselves. Moreover, the VOC dealt with different groups of roaming nomads in their quest for more cattle. Each time the Dutch encountered another clan, a middle ground had to be formed in concert with a willing and able local mediator, as the colonizers remained unwilling to learn Khoikhoi and were unable to distinguish different dialects. Despite initial disadvantages, continuing to speak their own tongue signified Dutch power over the 'other', and over time the language of the 'victor' did indeed become the dominant idiom.

In the founding years of the Cape settlement a few 'beach-ranger' natives became important to the Dutch as go-betweens, helping them to negotiate trade and introducing them to the Cape's nature and its people. These mediators tried to maintain and manipulate the middle ground that was established around the VOC fortress, while helping to construct similar spaces of negotiation with other groupings further inland. One individual played a key role: a young woman called Krotoa, who supplied the Commander with information on the whereabouts of roaming herdsmen and their cattle. Furthermore, she collected and passed on knowledge about the South-African geography and geology. In turn, she used her Dutch connections to settle disputes regarding pastures and cattle between her kinsmen and their rivalling groups, and she mediated between Dutch and Khoikhoi conflicts by trying to appease both parties. ${ }^{36}$

In 1654, the twelve-year-old Krotoa entered the Riebeeck household. Her relatives regarded her presence in the household of this foreign 'chief' as honourable and as a token of friendship. Her task, at first, was minding the children of Riebeeck and their cousins. Here, she received her Dutch name Eva. Again the Dutch acted as if they were Adam by naming her after the first woman God created. During her stay, she learned to read and write and she became familiar with Dutch culture.

Krotoa became the Commander's most trusted translator and informant, gathering knowledge on distant peoples, their habits and wealth along the way. This fuelled the VOC's thirst to obtain (semi-)precious metals and minerals, which they believed could be found somewhere further inland. A 1623 chart drawn by the mapmaker and adventurer Jan Huygen van Linschoten made this notion tangible. It indicated the whereabouts of the Monomotapa, a mythical and powerful people who lived close to the Vigiti Magna River. The Cape VOC officers seized every chance to prove that the charted information was correct. Krotoa's effort to collect local knowledge helped the Commander organize expeditions inland. These expeditions had multiple goals; to search for more cattle and trade-willing nomads, enable an inquiry into the Cape's nature, and find the mythical river Vigiti Magna and the Monomotapa.

Krotoa informed the Commander that two nomadic groups living deeper inland could bring them to the river and beyond. These groups were known as the Namaqua 
THE COMPANY'S GARDEN AND THE (EX)CHANGE OF NATURE AND KNOWLEDGE AT CAPE OF GOOD HOPE (1652-1700)

and Chobonas. The Namaquas (sometimes spelled Amaquas), she said, were approximately twenty to thirty days on foot away from the Cape. They had light skin, long hair and lived in stone houses, had churches, and prayed to a god like the Dutch. The Dutch could obtain elephant tusks and large quantities of cattle from them, for which the Namaqua in return desired copper pieces and brass string, red beads, and so forth. She claimed that the Chobonas lived even further inland and possessed gold and pearls. This sounded very promising to the VOC officers, for maybe the Chobonas wanted to trade and direct them to the river Vigiti Magna. ${ }^{37}$

It is unlikely that this young girl, living mostly with the Dutch, possessed this information beforehand. She had to make an effort to find out more about these distant groups. Both were akin to Krotoa's people, but differed somewhat in appearance and language. To make her story trustworthy she added to the obtained local information her knowledge of Dutch presumptions as contained in the Van Linschoten chart. She accumulated and transformed knowledge in order to present a credible story. By creatively combining her understanding of Dutch and local stories, she fabricated a promising middle-ground geography that the Dutch found credible enough to guide them on their quest inland. ${ }^{38}$

Krotoa's motivations to help the settlers remain unclear; what was she or her people to gain? Historian Siegfried Huigen speculates that 'Eva' was just sweettalking the VOC by combining Dutch beliefs with local stories, whereas historian Julia Wells argues on the other hand that Krotoa tried to serve the interests of her kinsmen by securing her position as 'ambassador' while she simultaneously assisted the Dutch in finding new trading partners. Wells emphasizes Krotoa's role of intermediary between both parties, as a girl who actively gathered information and then transformed local knowledge into Dutch, fitting it into the VOC's knowledge network in order to benefit her own people. ${ }^{39}$

In November 1661 the VOC organized an expedition to find the Namaquas and get one step closer to the Vigiti Magna and thus to the riches of the Monomotapa. The leader of the expedition was instructed to make "calculations with the compass and draw on a map how many hours, half hours, longer or shorter, taken on their course, in the way helmsmen do that at sea." Furthermore, the VOC wanted additional information regarding the soil. The expedition should

Add where [they] found clay for farmland, sandy, stony, hilly, and the flow of rivers and their course; if there is anywhere in the mountains or rivers any type of mineral, silver or gold; make note on the roads and the conditions thereof, and write down the most significant sites with the names of the people and their superiors and their cities, so we know that in the future. 
THE COMPANY'S GARDEN AND THE (EX)CHANGE OF NATURE AND KNOWLEDGE AT CAPE OF GOOD HOPE (1652-1700)

The collected and processed data informed the VOC board in Amsterdam and Batavia about the Cape's nature and the possibilities to explore and exploit its land in the future, to further their agricultural and mining activities. ${ }^{40}$

The VOC appointed the Danish VOC under-surgeon Pieter van Meerhoff to keep all travel records. The young Meerhoff became the father of Krotoa/Eva's two children and, after she converted to Christianity, her husband. Krotoa remained at the Cape, but it was likely that she had given Meerhoff all the information she possessed on the Namaqua. Her role as mediator expanded beyond her physical presence and probably contributed to the success of the 1661 mission. ${ }^{41}$

In the official expedition journal Meerhoff recorded the company of a few Khoikhoi who acted as intermediaries. These nameless guides gathered and translated information from the nomadic groups they met along to way. One of these groups, the Sonquas, informed the Dutch about the possibilities of finding water along a certain route that would take them to the territory of the Namaqua. The Dutch combined their charts, based on older maps and speculative information, with the accumulated local knowledge of the natives. Meerhoff welded the collected information into the official reports and onto the maps enabling later expeditions as well as the VOC head office to follow in their footsteps. ${ }^{42}$ [see picture 3.7]

The Dutch persuaded one Sonqua to accompany them to the Namaqua, in exchange for some tobacco. When they encountered the Namaqua, the Table Bay and the Sonqua guides received instructions to explain that the expedition had come in peace. The intermediaries and the Namaqua started their communication at a distance, on either side of a swamp. After long negotiations, the Namaqua allowed the Dutch to come closer, accepting their gifts of bread and stuffed tobacco pipes, which the Dutch showed how to smoke. The first steps toward the establishment of a middle ground between the two groups seemed successful. The expedition party left with some livestock bartered against copper, pipes, and tobacco, urging the Namaquas to come to the Fortress at Table Bay with their herds in order to trade larger quantities. ${ }^{43}$

The assumed agreement turned out not to be very solid, since the Namaquas did not show up at the Cape settlement. The VOC tried to regularize trade by organizing regular missions. But the Namaqua kept their distance staying well beyond the reach of the Dutch. The expeditions "were unable to meet or reach that nation, as the Namaquas had retired beyond a large area of 4 or 5 days journey, a dry, salt and sandy country, without even the least drop of water." The Dutch supposed that other groups scared the Namaqua away by "making them believe that it was our intention to injure them with a hidden force of men..." What motivated their decision can only be guessed. Maybe other Khoikhoi warned the Namaqua about the Dutch or the Namaqua refused to trespass the pastures of other groups on their way to the fortress. 
THE COMPANY'S GARDEN AND THE (EX)CHANGE OF NATURE AND KNOWLEDGE AT CAPE OF GOOD HOPE (1652-1700)

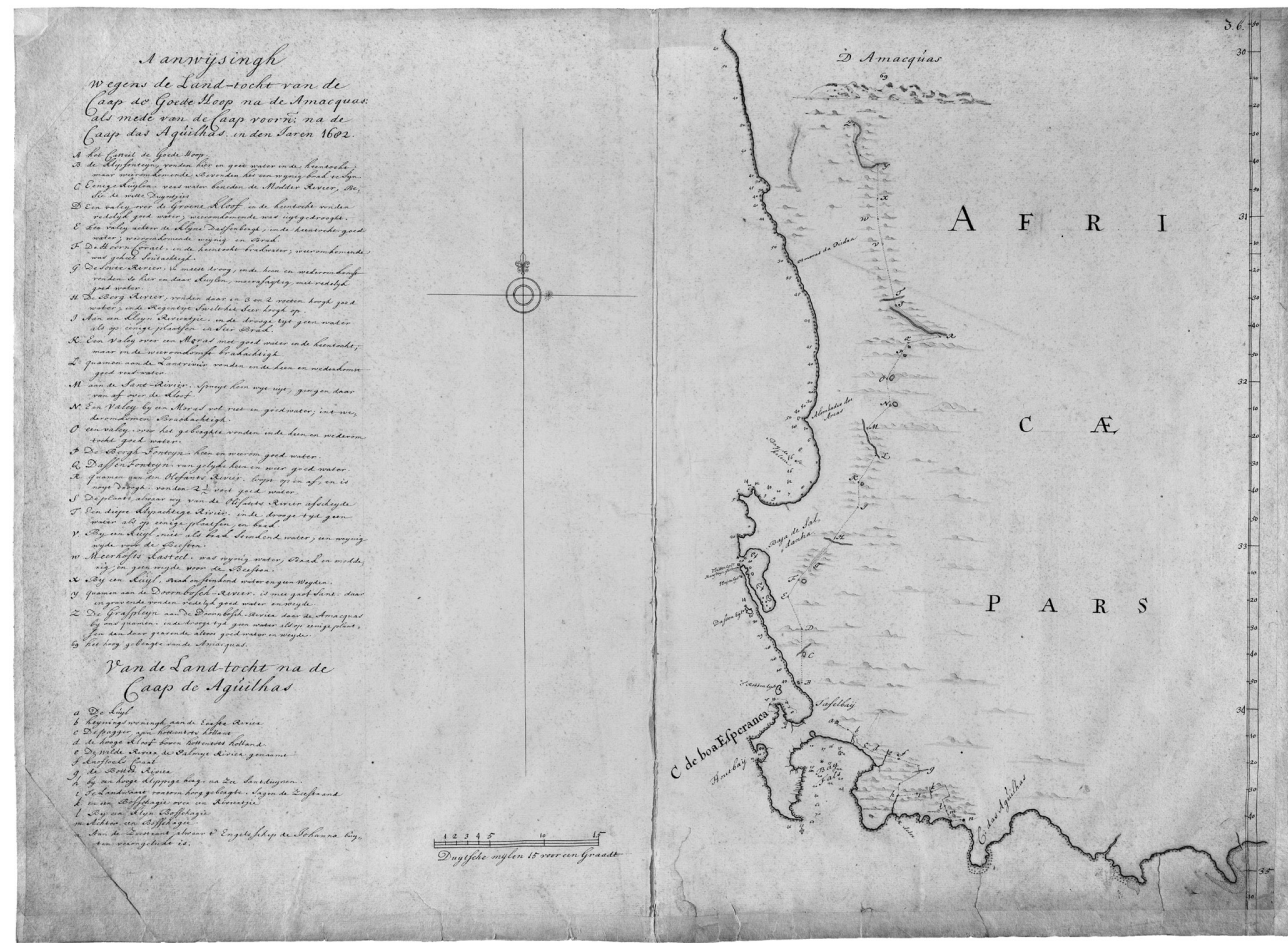

3.7) Anon., Map made after the expedition to the Namaqua in the year 1682, 4.VEL 850, Nationaal Archief, Den Haag

In any event, the Namaqua had not been won over by the VOC officers and refused take a further step toward the middle ground that the Dutch had tried to establish. ${ }^{44}$

Things changed for the Namaqua, when in 1685 a large expedition led by Governor Simon van der Stel pushed well into their territory. Packed with their charted knowledge and experiences of previous expeditions, this group of VOC men knew what to expect regarding water sources, routes, mountains, and other geographical obstacles. There was little need to obtain further information from other nomads. The growing Cape settlement and agricultural independence of the settlers went hand in hand with pushing further inland in search for cattle and natural riches. More and more Khoikhoi groups became familiar with the Dutch and their mercantile needs. The necessity to maintain a middle ground in order to allow trade had faded. The VOC position at the Cape grew stronger, and did not depend on the services of local translators and guides. ${ }^{45}$

Krotoa's role as go-between diminished in just over a decade. The departure of Riebeeck as Commander changed her position as a dependable translator. His suc- 
cessor Zacherias Wagenaar did not regard her as notably trustworthy, even though she had converted to Christianity and married Meerhoff. Then, in 1666 her husband died, leaving her without an income. Her situation went into further decline, since the Company did not need her services as translator. She died eight years after her husband, after being accused of being an ill-fit mother, a prostitute, and an alcoholic. The Dutch opinion of her had changed from that of a valuable intermediary to a nuisance and they expelled her from the settlement. Krotoa/Eva fell victim of the deteriorating relationship between the two cultures as the colonizers took over more and more Khoikhoi land, local knowledge and practices, therefore making her services as an intermediary redundant. ${ }^{46}$

The Dutch no longer needed mediators for their commercial and agricultural enterprise. The Khoikhoi groupings became marginalized as the VOC either pushed them into a peripheral existence or incorporated them into the colonial realm. Returning to the 1692 chart, we see that the mapmaker transformed the mobile huts of the Khoikhoi into small circles that were firmly placed in a geometrized landscape [see Fig. 5 above]. The 'vacant land' had been neatly filled. The worldwide network of the Dutch trade company and its linked centres of accumulation proved stronger than the nomadic culture of the Khoikhoi. The middle ground within which the Dutch and the Khoikhoi temporarily operated was no longer in place, the need for a partnership was gone.

\section{Conclusion}

The constitution of a middle ground initially allowed the two parties to negotiate trade and information. It was a way to come to terms with their mutual distrust and the desire for the goods of the 'other'. At the same time both tried to gain the upper hand over the situation while trying to explain or justify these actions in order to maintain or strengthen their own positions. The Khoikhoi at first dominated the middle ground since they possessed knowledge of the lands, its vegetation, and its peoples. The indigenous inhabitants occupied it through their understanding of nature and way of living, while the Dutch joined them out of need. Partially because the Khoikhoi circulated their accumulated knowledge and practices orally and manually, however, the Dutch would manage to strengthen their position.

The Dutch motivated and justified their (agri)cultural conquest by propagating the notion of a vacant land, often fixed in the mobile form of written charts, maps and regulations. Since the VOC in Holland stimulated the Cape settlement to become financially independent they urged the colonizers to expand their agricultural enterprise. This entailed taking from the natives their natural and geographical knowledge 
THE COMPANY'S GARDEN AND THE (EX)CHANGE OF NATURE AND KNOWLEDGE AT CAPE OF GOOD HOPE (1652-1700)

and practices in order to augment cultivation and trade. The balance on the middle ground changed as the Dutch became familiar with the Cape environment and had ways to contain this knowledge in charts, reports, and deeds. This written knowledge was then transported and exploited in order to strengthen the European knowledge and mercantile centres, while these facts simultaneously became disconnected from their original Khoikhoi roots. Subsequently, the settlers had no more use for a middle ground or mediators to negotiate such a space.

When the Dutch arrived at the Cape, however, this land was indeed not empty nor did it lie there waiting to be discovered and cultivated. Lacking a centre of accumulation does not imply that the Khoikhoi were 'bereft of all science'. Their mobile culture moved along different (nomadic) paths. Without a 'paper' circulation to anchor and connect concentrations of accumulation and sources or the firepower to back up its claims, the Khoikhoi knowledge network did not stand much of a chance against the strong VOC network.

The vacant land myth allowed for the 'development' of both nature and natives and exploration and exploitation for the benefit of the commercial enterprise of the West. The agricultural undertaking gave rise to experiment and inquiry into the Cape's nature, originally mediated by the Khoikhoi. The nomads lacked a lasting infrastructure that was stabilized and strengthened by the immobility and permanence of centres. The Dutch trade network depended on a continuous production of representations on paper to manage the Company and the Cape settlement. This made their network the so-called victor. We should nonetheless reconsider the position of Europe as the 'scientific' or 'technological' driving-force in so-called uncultivated areas. Dutch dependence on local knowledge and practices was part of the ongoing agricultural and mercantile enterprise, while it slowly pushed the original inhabitants aside. The traces of the Khoikhoi and their network on the Cape land were once visible, but have since long, to use Mentzel's words, been washed away by the tidal waves of the VOC seas. 
THE COMPANY'S GARDEN AND THE (EX)CHANGE OF NATURE AND KNOWLEDGE AT CAPE OF GOOD HOPE (1652-1700)

\begin{abstract}
"Earlier versions of this paper has been presented at the conference "Places of Knowledge: Relocating Science, Technology and Medicine" held at the Department of Science \& Technology Studies, Cornell University, Ithaca, 3-5 October 2008; at the conference "Dutch Trading Companies as Knowledge Networks" Leiden, The Netherlands, 23-24 October 2008 and the conference "Centers of Accumulation: Collecting points and the circulation of knowledge" held at the University of Ghent, Belgium, 28-29 November 2008. I would like to thank all the participants of these conferences for their remarks, and notably Professor Siegfried Huigen (Stellenbosch University, South Africa) and Benjamin Schmidt (University of Washington) for their valuable comments. I also deeply thank Prof. Lissa Roberts for her patient support and advice on earlier versions of my paper. Another version of this paper has been published as "(Ex)Changing Knowledge and Nature at the Cape of Good Hope, Circa 16521700," Siegfried Huigen and Jan L. de Jong (eds), The Dutch Trading Companies as Knowledge Networks, Intersections; Interdisciplinary Studies in Early Modern Culture, 14 (Leiden:
\end{abstract} Brill Publishers, 2010) pp. 243-265.

${ }^{1}$ O.F. Mentzel, A Geographical and Topographical Description of the Cape of Good Hope, (Cape Town: Van Riebeeck Society, 1921), 2 vols, vol. 1, p. 181. Batavia is nowadays known as Jakarta, Indonesia.

2 For more images and maps of the Cape of Good Hope visit http://www.atlasofmutualheritage.nl

3 The Dutch distinguished the hunter/gatherers San (or Bushmen) from the herdsmen Khoikhoi (or Hottentots). This was based on their practices (hunting/gathering or herding) rather than 'race'. A Khoikhoi without cattle became a San and vice versa. The seventeenth-century settler considered all 'Hottentots' more or less related to each other since they share a similar language. See: Elizabeth Elbourne, Blood Ground; Colonialism, Missions, and the Contest for Christianity in the Cape Colony and Britain, 1799-1853, (Montreal/Kingston: McGillQueen's University Press, 2002), pp. 71-75. I use 'Khoikhoi' as an encompassing name paralleling the 'Dutch' VOC servants. Although the VOC was a Dutch enterprise, its employees originated mostly from Germany and to a lesser degree Scandinavia, Poland, Portugal and France, see: Roelof van Gelder, Het Oost-indisch avontuur, Duitsers in dienst van de VOC, (Nijmegen: SUN, 1997), in this essay 'the Dutch' is used as shorthand for this mixed group.

${ }^{4}$ Richard Drayton, Nature's Government; Science, Imperial Britain, and the 'Improvement' of the World, (New Delhi: Orient Longman, 2005), see chapter 3 for an in-depth discussion on agriculture and gardening as justification for colonization of wild nature. Bruno Latour, Science in Action; How to follow Scientists and Engineers through Society, (Cambridge: Harvard University Press, 2003), p. 217. Latour argues that bringing back information makes "a second visit stronger than the first" which starts the whole cycle of accumulation that is accumulated in 'centres of calculation' that makes these centres strong. Likewise the VOC gained local information and goods that enabled the Company to grow stronger.

${ }^{5}$ Klaas van Berkel, "Een onwillige mecenas? De rol van de VOC bij het natuurwetenschappelijk onderzoek in de zeventiende eeuw," J. Bethelem and A.C. Meijer (eds), VOC en Cultuur, (Amsterdam: Schiphouwer en Brinkman, 1993), pp. 39-58.

6 See: Richard White, The Middle Ground, Indians, Empires, and republics in the Great Lakes Region, 1650-1815, (Cambridge/London: Cambridge University Press, 2007); M.L. Pratt, "Arts of the Contact Zone,” D. Bartholomae and A. Petroksky (eds), Ways of Reading, 
THE COMPANY'S GARDEN AND THE (EX)CHANGE OF NATURE AND KNOWLEDGE AT CAPE OF

GOOD HOPE (1652-1700)

(Boston/New York: Bedford-St. Martin's, 1999); M. Hall, “The Archaeology of Colonial Settlement in Southern Africa," Annual Review of Anthropology, 22 (1993), pp. 177-200; and D. Turnbull, "Boundary-Crossings, Cultural Encounters and Knowledge Spaces in Early Australia," Simon Schaffer, Lissa Roberts, Kapil Raj and James Delbourgo (eds), The Brokered World, Go-Betweens and Global Intelligence, 1770-1820, (Sagamore Beach: Watson Publishing International, 2009), pp. 387-428.

7 Latour, Science in Action, p. 220. He suggests that gaining knowledge is "a whole cycle of accumulation: how to bring things back to a place for someone to see it, at a distance."

8 We need to recall that virtually all the information we have about this is based on the (written) testimony of Westerners.

9 J.G. Grevenbroek, "An elegant and accurate account of the African race," I. Schapera and E. Farrington (eds), The Early Cape Hottentots The Early Cape Hottentots, (Westport: Negro Universities Press, 1970), pp. 161-299, see p. 179; Olfert Dapper, "Kaffrarie of Lant der Kaffers," in: Schapera and Farrington, The Early Cape Hottentots, pp. 1-77; D.B. Bosman and H.B. Thom (eds), Daghregister gehouden by den oppercoopman Jan Anthonisz van Riebeeck, (Kaapstad: A.A. Balkema, 1952-1957), 3 vols, vol 1, see p. 54

${ }^{10}$ William ten Rhyne, "A Short Account of the Cape of Good Hope and if the Hottentots who inhabit that region," in: Schapera and Farrington, The Early Cape Hottentots, pp. 81-157, see p. 153; on mallow and other plants see: http://www.plantzafrica.com/planthij/hermannia. htm and on toxic plants: M.L. Wilson, Th. Toussaint van Hove-Exalte and W.J.J. van Rijssen (eds), Codex Witsenii, (Cape Town/Amsterdam: Davidii Media, 2002), p. 10; on the familiarity of events see: Latour, Science in Action and Claude Lévi-Strauss, The Savage Mind, (Chicago: University of Chicago Press, 1968), p. 14.

${ }^{11}$ Grevenbroek, "Elegant and accurate account," p. 245; Guy Tachard, Voyage to Siam, (Bangkok: Orchid Press, 1999), p. 71; the travel account of Johann Wilhelm Vogel in: R. Raven-Hart, Cape Good Hope 1652-1702, The First Fifty Years of Dutch Colonisation as seen by Callers, (Cape Town: A.A. Balkema, 1971), 2 vols, vol. 1, p. 213; Peter Kolb, Naaukeurige en uitvoerige beschryving van Kaap de Goede Hoop, (Amsterdam: B. Lakeman, 1727), 2 vols, vol. 1, p. 463.

${ }^{12}$ E.E. Mossop (ed), Journals of the Expeditions of the Honourable Ensign Olof Bergh (1682 and 1683) and the Ensign Isaq Schrijver (1689), (Cape Town: Van Riebeeck Society, 1931), pp. 233-4; Shula Marks, "Khoisan Resistance to the Dutch in the Seventeenth and Eighteenth Centuries," The Journal of African History, 13 (1972), pp. 55-80, p. 60; Richard Elphick, Khoikhoi and the founding of White South Africa, (Johannesburg: Ravan Press, 1985), see pp. 65-67.

${ }^{13}$ Marks, "Khoisan Resistance," p. 63.

14 Dapper, "Early Cape Hottentots," p. 45.

${ }^{15}$ Arend W. Biewenga, De Kaap de Goede Hoop, Een Nederlandse vestigingskolonie, 16801730, (Amsterdam: Vrije Universiteit 1999), p. 23.

${ }^{16}$ On the vacant land myth, see: Andrew Bank, "The Great Debate and the Origins of South African Historiography," The Journal of African History, 38 (1997), pp. 261-281. On the production and exchange of facts, see: Harold J. Cook, Matters of Exchange, Commerce, Medicine, and Science in the Dutch Golden Age, (New Haven/London: Yale University Press, 2007). For in-depth discussion on agriculture and gardening as justification for coloniza- 
tion of wild nature see: Drayton, Nature's Government, chapter 3 and Alette Fleischer, "The Beemster Polder: Conservative Invention and Holland's great Pleasure Garden,” P. Dear, S.J. Schaffer and L.L. Roberts (eds), The Mindful Hand; Inquiry and Invention from the late Renaissance to early Industrialisation, (Amsterdam: Edita, 2007), pp. 145-166 on the improvement of nature in Holland. See the account of Schreyer, Johann, "Reise nach dem Kaplande und Beschreibung der Hottentotten, 1669-1677," S.P. L'Honoré Naber (ed), Reisebeschreibungen von Deutschen Beamten und Kriegsleuten im Dienst der Niederländischen West- und Ost-Indischen Kompagnien 1602-1797, (Den Haag: Martinus Nijhoff, 1930-1932), 13 vols, vol. 7, pp. 114-139.

17 There is extensive literature on the Cape of Good Hope founding years, as well as primary sources. The National Archives in The Hague houses the VOC archives and the in the Cape Town Archives Repository Resolutions of the Council of Policy of Cape of Good Hope, http:// databases.tanap.net/. Published material can be found in H.C.V. Leibbrandt, Precis of the Archives of the Cape of Good Hope, Letters Despatched from the Cape, 1652-1662, to which are added land grants, attestations, journal of voyage to Tristan da Cunha, names of freemen etc., (Cape Town: W.A. Richards and Sons, 1900); Bosman and Thom, Daghregister; and online http://databases.tanap.net/. Other published sources: Schapera and Farrington, The Early Cape Hottentots; George Meister, Der Orientalisch-Indianische Kunst- und Lust-Gärtner, eds. Friedemann Berger and Wilfried Bonsack, (Weimar: Gustav Kiepenheuer Verlag, 1973); Mentzel, A Geographical and Topographical Description; Tachard, Voyage to Siam; F. Valentyn, Beschryvinge van de Kaap der Goede Hoope met de zaaken daar toe behorende, eds. P. Serton, R. Raven-Hart and W.J. de Kock (Cape Town: Van Riebeeck Society, 1971); A.J. Böeseken, Memoriën en instructiën, 1657-1699, (Cape Town: Staatsdrukker, 1966); G. Waterhouse (ed), Simon van der Stel's Journal of his expedition to Namaqualand, 1685-6, (London/New York/Toronto: Longmans, Green, 1932). See for recent literature: M. Verstegen, De Indische Zeeherberg, De stichting van Zuid-Afrika door de VOC, (Zaltbommel: Europese Bibliotheek, 2001); Leonard Guelke, "The Anatomy of a Colonial Settler Population: Cape Colony 1657-1750," The International Journal of African Historical Studies, 21 (1988), pp. 453-473; Leonard Guelke and Robert Shell, "Landscape of Conquest: Frontier Water Alienation and Khoikhoi Strategies of Survival, 1652-1780," Journal of Southern African Studies, 18 (1992), pp. 803-824; K. Schoeman, Armosyn van die Kaap, die wêreld van 'n slavin, 1652-1733, (Cape Town: Human \& Russeau, 2001); Mia Karsten, The Old Company's Garden at the Cape and its Superintendents; Involving an Historical Account of the Early Cape Botany, (Cape Town: Maskew Miller Ltd, 1951); Biewenga, Kaap de Goede Hoop; Elphick, Khoikhoi and the founding.

${ }^{18}$ Waterhouse, Simon van der Stel's Journal, p. 4; S.J. Harris, "Long-Distance Corporations, Big Sciences, and the Geography of Knowledge," Configurations, 6 (1998), pp. 269-304.

${ }^{19}$ Elphick, Khoikhoi and the founding, p. 86.

${ }^{20}$ Schoeman, Armosyn van die Kaap, pp. 18-19.

${ }^{21}$ Schreyer, "Reise nach dem Kaplande," p. 22. Das Land ist alles ungebauet, ungeräumet, allerdings, wie es in der Schöpffung von Gott erschaffen worden. Und halte ich davor, wenn Leute wären, welche diese ungebaute Erde beaueten, pflantzten und bewohneten, daß hier das beste Land seyn solte, besser als in gantz Europa nicht zu finden. See for more on "motley crew" on British ships and colonies: Peter Linebaugh and Marcus Rediker, The Many- 
THE COMPANY'S GARDEN AND THE (EX)CHANGE OF NATURE AND KNOWLEDGE AT CAPE OF GOOD HOPE (1652-1700)

Headed Hydra; Sailors, Slaves, Commoners, and the Hidden History of the Revolutionary Atlantic, (Boston: Beacon Press, 2000), pp. 26-29, and see Gelder, Oost-indisch Avontuur, pp. 56-57 for the Dutch situation.

${ }^{22}$ Karsten, Old Company's Garden, p. 24, Meister, Orientalisch-Indianische, p. 26; the VOC feared that the camphor might get stolen by the competition as brought forth by Johannes Heniger, Hendrik Adriaan van Reede tot Drakenstein (1636-1691) and Hortus Malabaricus; a contribution to the history of Dutch colonial botany, (Rotterdam/Boston: A.A. Balkema, 1986), p. 75.

${ }^{23}$ A number of historians and sociologists of science have commented on this process where human and environmental spaces are standardized in order to accommodate the production of scientific knowledge. David Livingstone sums this up by calling laboratories 'placeless places' see: David N. Livingstone, Putting Science in its Place, Geography's of Scientific Knowledge, (Chicago/London: The University of Chicago Press, 2003), p. 23.

${ }^{24}$ Verstegen, Indische Zeeherberg, pp. 31-40.

${ }^{25}$ Karsten, Old Company's Garden, pp. 3-4, 56-7, 60. Valentyn, Beschryvinge van de Kaap, p. 206.

${ }^{26}$ Drayton, Nature’s Government, pp. 51-60.

${ }^{27}$ Karsten, Old Company's Garden, p. 11.

${ }^{28}$ J.B. Harley, The New Nature of Maps, Essays in the History of Cartography, ed. Paul Laxton, (Baltimore/London: The Johns Hopkins University Press, 2001), pp. 169-195.

${ }^{29}$ Elphick, Khoikhoi and the founding, p. 124 and further; Guelke and Shell, "Landscape of Conquest," pp. 803-824.

${ }^{30}$ See for renaming of plants: D.O. Wijnands, M.L. Wilson and T. Toussaint van Hove, Jan Commelin's Monograph on Cape Flora, (Stellenbosch: University of Stellenbosch Printers, 1996); J. du P. Scholtz, Naamgewing aan Plante en Diere in Afrikaans, bydrae tot 'n geskiedenis van die Afrikaanse woordeskat, (Elsiesrivier: Nasou Beperk, 1974); Mary Gunn and L.E. Codd (eds), Botanical Exploration of Southern Africa, (Cape Town: A.A. Balkema, 1981), pp. 24-25.

${ }^{31}$ J.L.W. Stock, "The Diary of a Cattle Expedition among the Hottentots in 1707," The English Historical Review, 31 (1916), pp. 610-622.

${ }^{32}$ White, The Middle Ground, p. 52.

${ }^{33}$ Grevenbroek, "Elegant and accurate account," p. 283.

${ }^{34}$ Bosman and Thom, Daghregister, vol. 2, p. 135, see the entry of 6 June 1657.

${ }^{35}$ Resolutions of the Council of Policy of Cape of Good Hope. Reference code: C. 7, 1 December 1671.

${ }^{36}$ See for Krotoa's efforts: Resolutions of the Council of Policy of Cape of Good Hope Cape Town Archives Repository, South Africa, Reference code: C. 1, p. 387, 30 October 1658, C. 2, pp. 10-13, 21 June 1659, C. 2, pp. 17-19, 1 July 1659. And: Julia C. Wells, "Eva's Men: Gender and Power in the Establishment of the Cape of Good Hope, 1652-74," The Journal of African History, 39 (1998), pp. 417-437, notably page 420. This article gives a good insight in Eva's position as go-between and her ability to make use of the given situation.

${ }^{37}$ Resolutions of the Council of Policy of Cape of Good Hope, Cape Town Archives Repository, South Africa, Reference code: C. 1, pp. 402-403. 1 February 1659. 
${ }^{38}$ See Harold Cook's unpublished paper "Capitalism and Science" on the connection between credit/trust and accumulation of knowledge/money.

${ }^{39}$ Wells, "Eva's Men,"; Siegfried Huigen, De weg naar Monomotapa, (Amsterdam: Amsterdam University Press, 1996), p. 46.

${ }^{40}$ Bosman and Thom, Daghregister, vol. 3, p. 410. Daer dan mede bijvougen waer cley ofte bougront, sandigh, steenigh, berghachtigh, en waterafflopende revieren sijn, en hoe sij strecken; ook te stellen off ergens in 't geberghte ofte revieren eenigh minerael steekt daer silver off gout uyt te tre[c]ken sij. Item acht te nemen off de wegen overal off ergens met wagens sullen te passeeren sijn, gevende sommige remarcable plaetsen ook namen van 't volcq en haer oversten ende steden, om te kennen in toecomende.

${ }^{41}$ Huigen, Monomotapa, pp. 35 and 54 and further.

42 Bosman and Thom, Daghregister, vol. 3, p. 482.

${ }^{43}$ Ibid., vol. 3, p. 486.

${ }^{44}$ Leibbrandt, Precis of the Archives, vol. 3, p. 219.

${ }^{45}$ Wilson, Toussaint van Hove-Exalte and Rijssen, Codex Witsenii, p. 12; Wijnands, Wilson, Toussaint van Hove, Jan Commelin's Monograph, p. 15. Huigen, Monomotapa, pp. 49-51.

${ }^{46}$ Wells, "Eva's Men," pp. 417-437. 


\section{Chapter four}

\section{Holland's hortus and Baltic botany: transforming and transporting 'mother nature' along the 'mother of all trades' route.}

\section{Introduction}

In 1678 Jacob Breyne's exotic herb book Exoticarum aliarumque minus cognitarum Plantarum centuria prima, printed in Danzig, appeared. The Dutch merchant and amateur botanist collected and published a portion of all the rare plants he found when visiting several gardens in the Low Countries in the years before. In a long dedication Breyne particularly thanked his patron the Dutch statesman and botanical collector Hieronymus van Beverningh. ${ }^{1}$ Beverningh had supported this herbal, as such books were called, by bringing him into his network. He invited Breyne to his garden and gave him access to his manuscripts, drawings, dried plant specimens, bulbs, and seeds. Most of the vegetation discussed in the Centuria as this book is now known, had made their way from the Cape of Good Hope, the Far East (Ceylon, Batavia, and Japan), and South America to Beverningh's garden. Additionally a small number of plants came from the region around Danzig and had been collected by Breyne personally. [see picture 4.1]

This herbal showcased the intricate ties between Dutch private gardens, the country's Horti Botanicus, and the import of foreign plants via the Dutch East and West India Companies. While such links have been noted and explored by other historians, this book did more. It also highlighted the role played by the Moedernegotie - the 'mother of all trades' as the cereal trade from the North-East of Europe was then known - in adding to the growing body of botanical knowledge. Together, Beverningh's garden and plant collection in Warmond near Leiden and the herb books of exotic and Polish plants compiled by Breyne allow us to map the ways in which trade along this major route and inquiry into nature became productively linked, a topic to which historians have not yet attended. The city of Danzig was an especially important node in the commercial and knowledge networks that both plied this route and linked it to international trade elsewhere. Between Amsterdam and Danzig, amateurs, botanists, merchants, physicians, and artists exchanged physical and paper plants, explanations and exsiccates, and transplanted them firmly in contexts such as gardens and herbals thereby allowing others to examine and enjoy nature's treasures. 


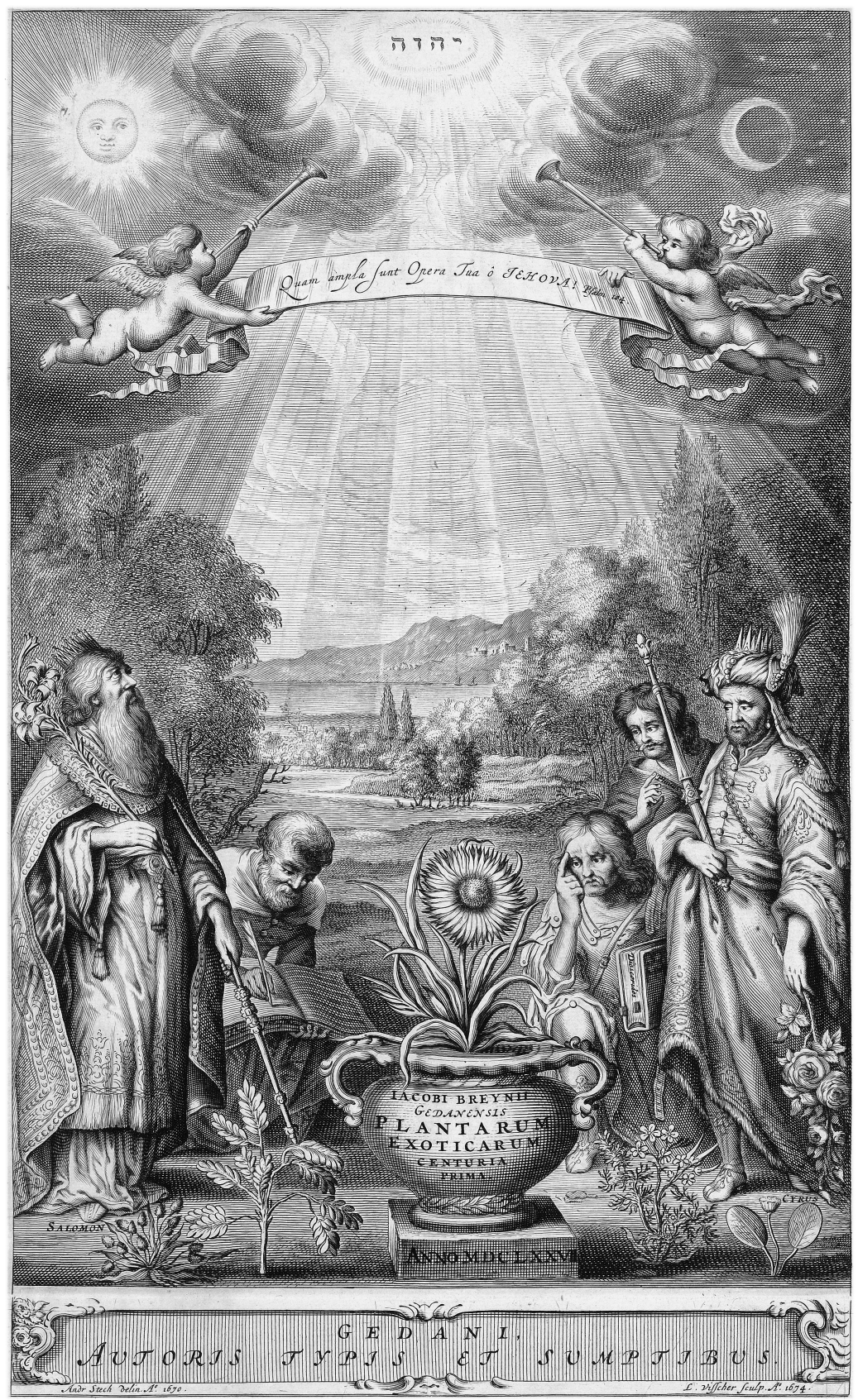

4.1) Andreas Stech (draftsman) and Lambert Visscher (engraver), Frontispiece, Jacob Breyne, Exoticarum aliarumque minus cognitarum Plantarum centuria prima, (Danzig, 1678), NCB Naturalis, section National Herbarium of the Netherlands, University of Leiden, Leiden 
HOLLAND'S HORTUS AND BALTIC BOTANY: TRANSFORMING AND TRANSPORTING 'MOTHER NATURE' ALONG THE 'MOTHER OF ALL TRADES' ROUTE.

During the last thirty years, historians have elaborated on the construction and use of herb books and their role in the constitution of natural knowledge, thereby helping to broaden the geography and scope of the Scientific Revolution to include exotic and local botany and medicine. Johannes Heniger, Londa Scheibinger, and Claudia Swan, for instance, explain how non-European medicinal plant knowledge entered European herb books. ${ }^{2}$ Others focus on the connection of exotic botany, medicine and pharmacy, ${ }^{3}$ or discuss the connection between herbals and botany in general. ${ }^{4}$ For example, historian Alix Cooper connects inquiry into local botany and the publication of herb books in the early modern German region of Altdorf. ${ }^{5}$

In a recently published article, historian Daniel Margocsy focuses more specifically on the use of herbals amongst botanists and on how herbals enabled communication and exchange among botanists. ${ }^{6}$ All these researches begin with an examination of how botanists, gardeners, patrons, and physicians collected elements of nature and knowledge which were either gathered locally or across great distances and how they examined, named, and ordered flora, which led to the production of different sorts of herb books, focussing on medicinal use, local or foreign flora, beauty or on plant growth and maintenance. The influx of exotic plant material and knowledge brought to Europe, most famously via the Dutch East India Company (VOC), motivated the publication of herbals in the seventeenth century just as it retrospectively motivates the investigations of current historians who are interested in links between commercial and knowledge exchanges, and the nodes of communication that made them possible?

Besides exotic sites, producers and consumers of herbals and gardens found other fertile ground, closer to home, where they pursued natural inquiry, in both private gardens and public horti. ${ }^{8}$ In addition to the sites that are examined in most of the literature currently available, knowledge production also took place in private estates in Holland where African, American, and Asian plants and knowledge shipped from overseas were collected, as well as in the fields and chambers of Dutch, German, and Polish inquirers into botany in Pomerania. ${ }^{9}$ As historian Staffan Müller-Wille argues naturalists "depended on local institutions, collections, and botanical gardens in particular" whereby collecting and exchange took place between multiple centres and peripheries, instead of a transfer of matter and knowledge towards one centre of accumulation..$^{10}$ Indeed, here we have a mixture of mediators, scattered over the various segments of the Dutch trading network, who exchanged and transformed flora and natural knowledge to collectively further natural inquiry while propagating nature's riches and promoting the enjoyment of collecting and examining actual and paper plants. 
This chapter reconnects Beverningh's private garden with Breyne's herbal that, in part, stemmed from it, arguing that both are sites of intersection that depended on and gave rise to (further) natural inquiry in the Low Countries, Poland, and beyond. By focussing on Beverningh, his network, garden and collection of manuscripts and herb books, we can see how gardening entailed a cooperative displacing and transplanting of plants and information to and from actual gardens, and to other locations. Through his famous estate, people with different backgrounds such as political figures, merchants, professors, physicians, artisans, and botanists exchanged botanical knowledge and matter. Together they contributed to the construction, consumption, and production of natural inquiry and thereby transformed nature into an object of astute admiration, creative contemplation, and productive exploitation. The chapter returns to the familiar ties between Holland, England, and Asia. ${ }^{11}$ But it also stresses that the construction of natural knowledge during the seventeenth century equally and jointly took place along the trajectory that linked a private Dutch garden and Danzig in particular and the Moedernegotie and natural history in general.

This chapter thus draws our attention to the trading route called the Moedernegotie; which began to flourish from the second half of the sixteenth century. ${ }^{12}$ The Dutch considered the cereal trade as the mother of all trades, since it predated the VOC and was very profitable over a long period of time. The Dutch imported grains (corn and rye) from that region and, to a lesser extent, wood and saltpetre. They exported salt, red brick, and tiles, a cheap but weighty cargo. ${ }^{13}$ Along with the more obvious commercial activities, this mercantile network allowed for an exchange of people, knowledge, goods and paperwork, which entered and exited the important harbour of Danzig. Furthermore, it took Dutch traders, physicians, architects, and engineers to the Baltic area, to oversee and expand the cereal trade, while building a life for themselves there.

Historians of science and technology, who generally discuss the interactions between Holland-England-France, between Holland-Batavia-Japan, or to a lesser extent the Dutch West India Company and South America, have largely ignored this connection between Holland and the Baltic with two exceptions. In the first half of the eighteenth century, the connection between Sweden and Holland, through the travels of Linnaeus, receives the attention of historians, as has the ties between Peter the Great and the Dutch, especially the Czar's thirst for natural historical objects, instruments, nautical and agricultural inventions, botany, and medicine. ${ }^{14}$ The Baltic area itself is geographically smaller than the Asian regions with whom the Dutch traded, but the commercial turnover was enormous. Zooming in on the mother of all trades reveals how deeply commerce, culture and the pursuit of natural knowledge 
HOLLAND'S HORTUS AND BALTIC BOTANY: TRANSFORMING AND TRANSPORTING 'MOTHER

NATURE' ALONG THE 'MOTHER OF ALL TRADES' ROUTE.

were linked, whereby the inquiry into botany and the production of an herbal could prove the co-constructive undertaking of a Dutch patron, a Dutch-Danzig botanist, and Dutch, Polish, and German artisans.

By focussing on the mother trade, Beverningh's estate, and the construction of Breyne's herb books this chapter at the same time addresses the transportation of perishable plants to a garden and the transition of specimens into conserved vegetation in an herbal. To put it in Latourian terms, botanists and gardeners transformed and placed plants into mutable and immobile gardens and further adapted flora into immutable and mobile paper gardens such as herbals. This transformative act, enabled through trade, linked the local (various gardens and landscapes) to the global (through a published book).

To chart this complex story, this chapter begins with a short presentation of the Danzig-Dutch trading network and the role of the merchant-botanist Jacob Breyne. Then it introduces the statesman Hieronymus van Beverningh, his garden and collection of foreign plants that he received through his vast political, botanical, and mercantile network. Next follows a section on Breyne's herberia (books filled with dried plants) and his botanical activities. The penultimate section discusses the Dutch and Danzig artists engaged by Breyne to transform nature into art in order to produce a lasting and mobile herbal. The chapter concludes by reconnecting Beverningh's private garden in Holland with the paper garden from Danzig as two corresponding sites of intersection that followed the Baltic trade, bringing together the producers and consumers of cultivated nature.

\section{Danzig and the Dutch}

The ties between Holland and the Baltic region, constituted through the so-called mother of all trades, brought merchants, artists, and engineers to Danzig, while Polish fortune-seekers, in turn, came to the Low Countries to work for the VOC or to be trained as merchants. ${ }^{15}$ This section of Dutch history receives due attention by economic and maritime historians as the wealth of publications shows. ${ }^{16}$ Historians of science, however, tend to focus more on the botanical or scientific interactions between the Dutch, French and English connections, or focus largely on Dutch dealings with the exotic Far East and to a lesser extent, South Africa and Brazil. Many argue that the production of natural knowledge followed the Dutch trade routes of the VOC and the WIC, ending in Horti Botanicus, filling various cabinets of curiosity, and bringing to light exotic herb books such as the Hortus Malabaricus, or Albert Eekhout's paintings of Brazil's flora, fauna, and people. ${ }^{17}$ 
Trading indeed enabled the transplantation and transformation of people, matter and information from one location to the next whereby the Dutch could encounter local nature and interact with local people either directly or through the agency of go-betweens, the resulting fruits of which their trade routes brought back to Holland. This familiar story ignores, however, that significant quantities of exotic flora gathered along the VOC routes became reworked and printed in Danzig, after which the results were shipped and dispersed along the cereal routes to other regions. Breyne's important herbal Exoticarum aliarumque minus cognitarum Plantarum centuria prima can be seen as an intersection of plants and knowledge that stemmed partially from Beverningh's garden. But it did not stop there; he included plants he received from the Cape of Good Hope as well as several Polish plants that he considered to be rare. The Centuria showed that inquiry into nature and knowledge exchange moved between several distant places, whereby each site contributed to the production and transformation of natural knowledge.

Over 100 years before the founding of the VOC, the Dutch traded goods with the German/Polish areas, all the way up to the Baltic Sea, which really took off from the mid sixteenth century. ${ }^{18}$ An important port along this route was Danzig. Other trade destinations were Sweden, Estonia, and Russia where the Dutch traded for wood, copper, and fur. ${ }^{19}$ The Russian court, at one end of this trading trajectory, functioned as a magnet for certain enterprising Dutchman. In the mid-1660s, the Amsterdam burgomaster and merchant Nicolaes Witsen, for example, spent a short time there to establish trade. This stay enticed him to compile and publish a book Noord en Oost Tartarije on Russia and Siberia in 1692. The Baltic cities, especially after the founding of the new harbour St. Petersbug, saw an influx Dutch goods, books, plants, and people that followed the cereal trade while helping to give shape to this area. ${ }^{20}$

Danzig's bay welcomed the many Dutch ships with their cheap cargo of salt, brick, floor flags, and roof tiles and with luxury goods consisting of wines from Germany and France, and cloth from England. With the rise of the VOC trade, this shipping network brought precious spices, exotic plants, and delicate textiles from Africa, India, and Asia to Danzig. Ships went back loaded with cereals, wood, and flax that brought good profit for the Dutch. From the late sixteenth century, Danzig became an important node in the global network of the Dutch trading companies. Dutch merchants, therefore, expanded their position in this region and protected their interests by settling down in the Baltic area.

To secure an ongoing trade, merchants in Amsterdam worked with local agents, known as factors, who acted as go-betweens and negotiated trade for the Dutch. Usually a factor had an interest in the business to further ensure trust and trade. Another option for the Dutch merchant was to install a family member, usually a 
HOLLAND'S HORTUS AND BALTIC BOTANY: TRANSFORMING AND TRANSPORTING 'MOTHER

NATURE' ALONG THE 'MOTHER OF ALL TRADES' ROUTE.

younger brother, to take care of business on behalf of the whole family. With the growing volumes of cereal exported to the Low Countries, the number of Dutch moving to Danzig over the course of the seventeenth century increased. ${ }^{21}$ The merchants brought their trade practices as well, such as Dutch methods of bookkeeping, and a regular published commodity price lists appeared in Dutch, just as it was done in Amsterdam. ${ }^{22}$

Not only merchants moved from Amsterdam to Danzig. In their wake followed wives, architects, artists, engineers, and physicians. Some of them made a good living there and settled in Danzig for good, adapting to and marrying into the Danzig upper classes. For instance, the merchant Jacob Breyne married the Danzig-born Sarah Rogge in 1665. Sarah's father was skipper Gerhard (or Gerard) Rogge who originated from Doetinchem (county of Gelre in the Low Countries). He moved to Danzig and acquired citizenship in 1640, after which he became the city's mint master and engraver. ${ }^{23}$

Over the centuries the Dutch moved to Danzig either temporarily or permanently. In order to obtain citizenship they married into local society or simply purchased their rights. It could also happen that women married into the Danzig mercantile society. In the seventeenth century Danzig society was flexible enough to allow marriage between Dutch and local merchants and governors. One young woman's marriage with Danzig merchant and burgomaster underscored this. The rich woman, Elisabeth Koopman, was a daughter of an Amsterdam merchant who wed the wealthy brewer and burgomaster of Danzig, Johannes Hevelius (1611-1687), famous in the history of science for his astronomical work. In this case, the marriage accentuated the fact that Dutch settlers came to stay in Danzig. The mother of all trades enabled the Dutch and their Danzig counterparts, whether they were merchants, rulers, or astronomers, to become intricately linked to each other through trade, marriage, and a shared passion for natural inquiry.

As of yet, these ties have received little attention. Historians have largely focussed on individuals rather than place. This section briefly turns to Hevelius in order to illustrate how intricate Danzig-Dutch connection might be further examined. ${ }^{24}$ As a young man, Hevelius had spent a few years at the University in Leiden studying law. He returned to Danzig to follow in his father's footsteps. After his first wife died, he married the much younger Elisabeth. Both had a business background: Elisabeth's family traded in cereals and Hevelius' Bohemian-born parents brewed beer ('liquid bread' that consists largely of cereal). Husband and wife shared a passion for astronomy. An often-copied etching captures them handling the instruments during their nocturnal activities. To underscore their trustworthiness and expertise as disinterested amateur-astronomers, Hevelius and his wife wore clothes appropriate for so- 
cial gatherings, and not the sort of dress normally worn indoors. ${ }^{25}$ But even without their common interest in astronomy and despite their thirty-six years age difference, this marriage seemed profitable and sensible enough from a mercantile standpoint. It not only linked 'science' (the world of astronomy) and 'money' (the world of trade), it further indicated the strong connection between Holland and Pomerania and the integration of the Dutch into Danzig patrician society.

The mother trade transported people, papers, and knowledge in both directions, bringing many young Dutch to and through the Polish region. In the spring of 1656, Christiaan Huygens' youngest brother Philips stayed a few weeks in Danzig, before leaving to Sweden. He met Hevelius since he had to deliver a letter on behalf of Christiaan. He found the astronomer a "very nice little man" who was delighted with Huygens' book and leaflets. Hevelius "was now completely entangled with Saturn" and about to publish a treatise on Saturn and "the growing and diminishing of the ears." He informed young Philips that he would send a copy to Christiaan Huygens. ${ }^{26}$ In a way, the exchange between Huygens and Hevelius, mediated by Philips parallels the mercantile practice of sending family members to mediate trade between the home and away parties. In both trade and natural inquiry reliability played a major role in affording one negotiation of deals and knowledge exchange. Factors served as go-betweens, but it was often deemed better to mediate through a trusted family member. To expand trade and natural inquiry, the worlds of 'money and science' functioned along similar paths, and were often pursued by the same people. ${ }^{27}$

Aided by Dutch entrepreneurs and engineers, the city of Danzig prospered, which in turn enabled the Dutch to enter learned and/or noble Danzig society. Over time, the city grew and houses were built in the Dutch renaissance style. As in the Low Countries, these narrow and tall buildings with their curvilinear bell gables were made of brick and the ornaments carved in stone. This fashion followed the Dutch in their wake, as they brought not only the material but also the engineers and architects to design and build this environment. To name two examples: the engineer Simon Stevin, who we met in chapter one on the Beemster polder, went to Danzig to advise on the renovation of the harbour in 1591, and architect and painter Herman Vredeman de Vries constructed several buildings in Danzig between 1592 and 1595. ${ }^{28}$ [see picture 4.2 ]

Equally, the mother trade opened up Holland and its mercantile realm for adventurous young men from Poland who went to the Low Countries to study or to try to make their fortune by joining the VOC. ${ }^{29}$ For instance, engineer and architect Nicolaus Goldmann had left Wroclaw to study Law in Leiden. He remained there to teach engineering and fortification privately to students, including the Dutchman Tilman van Gameren and the Polish Jerzy Sabastian Lubomirski. In circa 1660 the Utrecht 


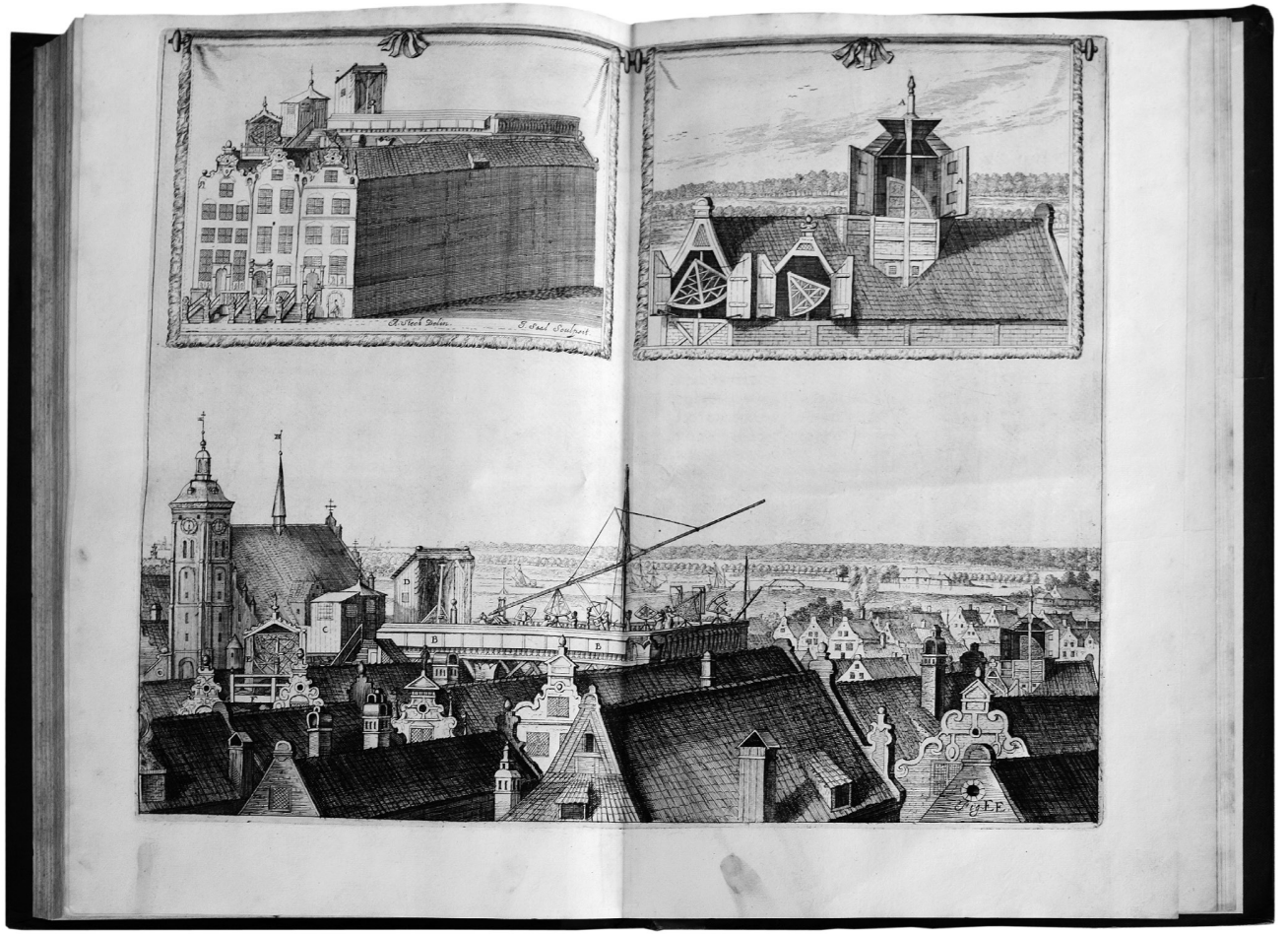

4.2) Andreas Stech (draftsman) and Isaac Saal (engraver), Johannes Hevelius's house and roof-top observatory in Danzig, J. Hevelius, Machina Coelestis Pars Prior (Danzig, 1673), special collections, University of Leiden, Leiden

painter and architect Gameren left Holland for Poland, on the invitation of Lubomirski. He stayed for the rest of his life building churches, houses and palaces for the nobility. ${ }^{30} \mathrm{~A}$ little later, around the turn of the century, the Danzig-born Gabriel Fahrenheit moved to the Low Countries. He was sent to Amsterdam by his family to be trained as a merchant. Since he was more interested in natural philosophy, he left the family business and turned to instrument making instead with well-known results. ${ }^{31}$

The Baltic region and Holland maintained strong ties over a long period of time. The intricate Dutch-Danzig connection took place on various levels with varying duration, involving men and women from different backgrounds and touching the fields of astronomy, natural history, trade, architecture, instrument making, art, and botany. The mother trade allowed for the exchange of people, paper, plants, and other objects. Steadily and surely, trade helped to shape Danzig physically and intellectually, while simultaneously it brought Polish knowledge and naturalia to the Low Countries. Both sites functioned as centres of accumulation and as sites that 
HOLLAND'S HORTUS AND BALTIC BOTANY: TRANSFORMING AND TRANSPORTING 'MOTHER NATURE' ALONG THE 'MOTHER OF ALL TRADES' ROUTE.

produced goods and books. ${ }^{32}$ Jacob Breyne showcased this exchange between Holland and Danzig through his inquiry into nature and the construction of his 'paper gardens'.

\section{Jacob Breyne and botany}

The botanist and tradesman Jacob Breyne (1637-1697) came from a family of well-to-do Dutch merchants. His parents, trading in dyes and drugs, moved via Hamburg to Danzig where Jacob was born. ${ }^{33}$ While at school he received lessons in botany from the German court physician Christian Mentzel (1622-1701) and together they went on excursions around Danzig. Breyne, as had Mentzel a little earlier, joined the Academia Naturae Curiosorum (later known as the Leopoldina). This was a group of physicians and natural historians from mostly the German regions including Danzig and a few from the Low Countries that from the 1670s produced publications on medicine and nature. ${ }^{34}$

Botany became Breyne's lifelong passion. In the early to mid-1650s, he was sent to the Low Countries to be trained as a merchant by his Dutch uncle Pieter Breyne [Braine] in Leiden. There he made time to take further lessons with the University of Leiden professor of medicine Adolf Vorstius (1624-1663) without matriculating there. ${ }^{35}$ While in Leiden the young man became acquainted with Hieronymus van Beverningh and his estate. The two men possibly met through Vorstius or via Breyne's family, consisting of merchants and councillors, who moved in the same ruling circles. ${ }^{36}$ Upon his father's demise in 1655, he had to return to Danzig to take over his father's business where he combined trade with his pursuit into local and exotic flora. ${ }^{37}$ Breyne was not the only amateur in the family. In Amsterdam his cousin Johannes, a merchant-druggist, owned a large collection of naturalia. Later, his son Johann Philip would study medicine under Professor Herman Boerhaave in Leiden in 1702, settling down in Danzig as a physician and botanist, and publishing with his father several herbals. Jacob's three granddaughters all became accomplished artists specialised in natural history. ${ }^{38}$

Back in Danzig, Breyne took time to journey through the countryside collecting local flora. After drying and pressing the plants he harvested, he compiled the multi-volume Herbarius vivus. His first herbarium dated from 1659 consisted of dried local plants with names mostly in Dutch and sometimes including additional information about the plant's habitus. ${ }^{39}$ His next herbarium, called Plantae rariones Borussicae et Cassubicae, consisted of four volumes of exsiccates collected around the Polish region in $1673 .{ }^{40}$ Breyne indicated in 1697 that he wanted to publish a book on "Prussian and Cassubian" plants, but first he wanted to undertake one more expedition in the summer and collect more plants, providing his health would im- 


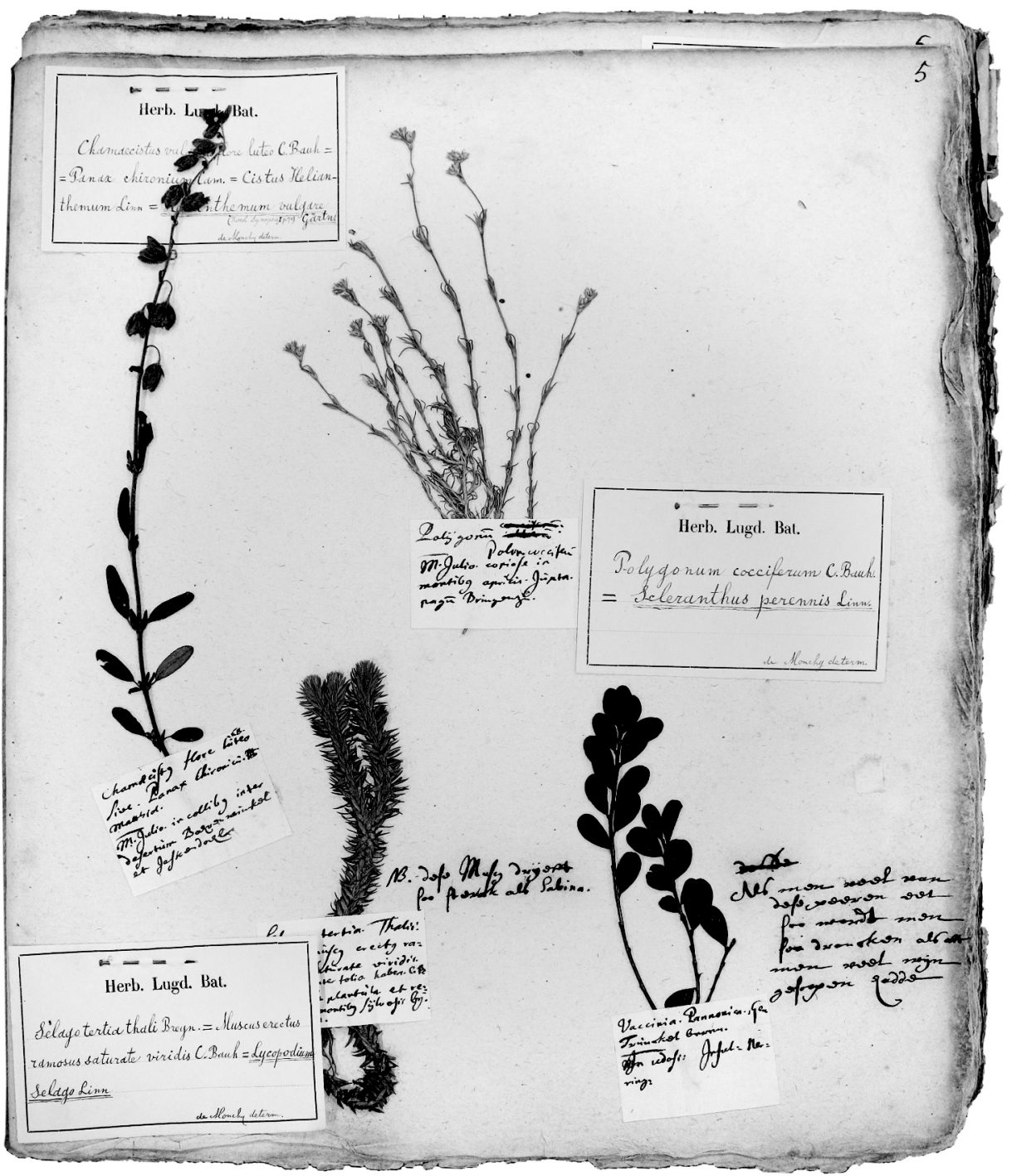

4.3) Jacob Breyne, Herbarium, Danzig, 1659, NCB Naturalis, section National Herbarium of the Netherlands, University of Leiden, Leiden

prove. ${ }^{41}$ However, his death prevented this publication. The accumulation of locally found plants transformed into herbaria formed for Breyne an intricate part of the production of his herb books. It allowed him to transform a plant into a reproducible print that could then be dispersed over a wider audience. This could have motivated Breyne to rework this herbarium into a book on "Prussian and Cassubian" flora. [see picture 4.3] 
Herbaria, even when compiled by the same person, could have multiple purposes. It all depended on the user's demands. Breyne's Herbarius vivus of 1659 with dried plants from the Danzig area consisted of several sections of loose-leave folded foliosized papers with pressed flowers. This herbarium appears to have been a personal collection of pressed plants, for his use only. On occasion, he provided a short description of the plant and its finding place in Dutch. This herbarius vivus functioned as a sort of reminder for Breyne of the flora he had encountered on his tours around the countryside; possibly this herbarium was a sort of sketchbook for his next herbarium on local plants. ${ }^{42}$ [see picture 4.4]

The use and function of this herbarium was different than the herbarium Borussicae et Cassubicae that Breyne compiled in a much neater way. Here he took the effort to group together flowers of the same type, with the names in Latin. For this he used the English botanist Robert Morison's system based on morphological features, notably the form and structure of fruit. ${ }^{43}$ This system enabled botanists and herbalists to compare plants originating from different parts of the world and classify foreign and local flora according to their appearance. Breyne used this method again when he compiled his herbal Exoticarum aliarumque minus cognitarum Plantarum centuria prima, where he placed certain Polish plants adjacent to similar exotic specimens, as will be discussed further below.

Breyne's mercantile and botanical connections were closely linked. He used the mother trade network to transport simultaneously nature and knowledge to and from Holland and from Japan, the Cape, and Batavia. His trade in dyes and drugs went hand in hand with the transportation of manuscripts, drawings, and specimens. This trade network allowed him to accumulate material from Dutch gardens and his other contacts, and to this growing body of natural knowledge he added locally found plants. His herbaria were a step along the way for him to transform flora to fit into the global knowledge network, by referring to existing nomenclature. ${ }^{44}$

When applicable, Breyne referred to names suggested in Caspar Bauhin's Pinax theatri botanici (1623). This herb book was widely used for reference and comparison at the time throughout Europe ${ }^{45}$ By using the Pinax, botanists were able to communicate with each other about plants, as Daniel Margocsy argues. Flora became 'recognisable' for other amateurs and botanists, who could verify the presented specimens with their copy of the Pinax.$^{46}$ Brenye furthermore categorized the Polish plants using Morrison's method, so that specimens not named by Bauhin could be discussed and compared with known samples. This way of working allowed him to compare flora to each other and notice similarities and differences, thereby contributing to a further understanding of nature. 
HOLLAND'S HORTUS AND BALTIC BOTANY: TRANSFORMING AND TRANSPORTING 'MOTHER

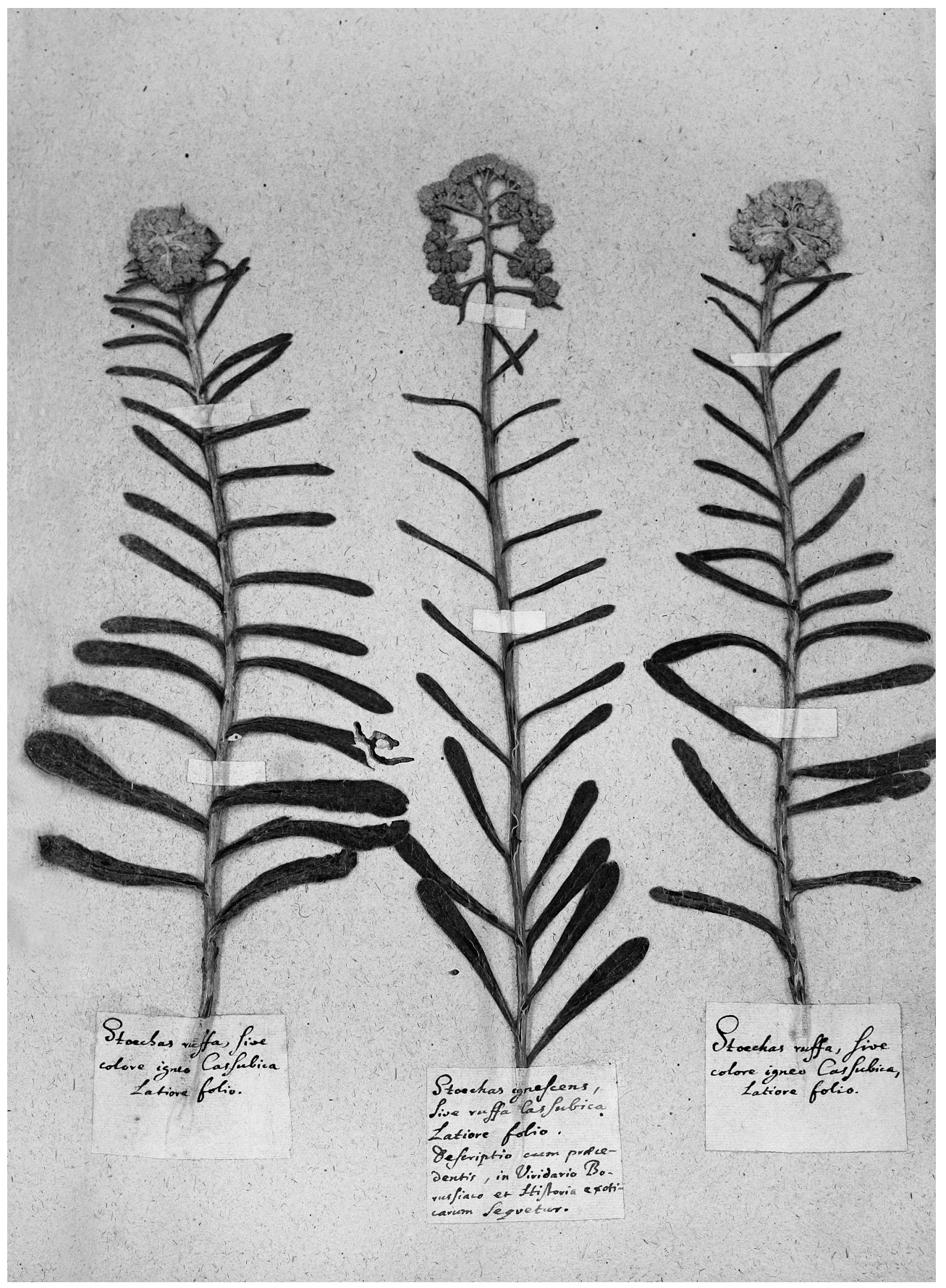

4.4) Jacob Breyne, Herbarium Planta rariorum Borussia et Cassubia, Danzig 1673, NCB Naturalis, section National Herbarium of the Netherlands, University of Leiden, Leiden 
Breyne's inquiry into nature, however, went beyond the accumulation of local flora and transforming the plants into exsiccates. He collected actual and paper flora directly from his contacts in Japan and Batavia, or through the garden of his patron, the retired statesman Hieronymus van Beverningh in Leiden. The merchant regularly travelled to Holland for his business and combined this with visiting gardens of other botanical enthusiasts to collect samples, seeds, and exsiccates of exotic flora. Often he visited Oud-Teylingen to examine Beverningh's collection, making notes of the cultivated exotic trees and plants and exchanging plant knowledge ${ }^{47} \mathrm{He}$ published the findings of his 1660s tour in his herbal Centuria of which Beverningh was the main sponsor. Breyne wrote a special dedication praising and thanking him, and had his patron's name printed in capital letters with each entry coming from Oud-Teylingen's garden. Before this chapter goes further with the publication of the Centuria, it introduces Beverningh and his vast collection of naturalia.

\section{Hieronymus van Beverningh}

Before he retired to the countryside, the statesman Hieronymus van Beverningh (1614-1690) had been counsel and burgomaster of the city of Gouda and a member of the States of Holland. ${ }^{48}$ In 1673, he became curator of the Leiden University and supervisor of the Hortus Botanicus. ${ }^{49}$ With this position he combined his passion for botany with his managerial skills. Among other things, this function entailed setting up a charter with rules and regulations for proper conduct and against misbehaviour in the garden. ${ }^{50}$ Beverningh suggested hiring an extra gardener to help maintain the expanding garden, since in 1686 the university had enlarged the terrain. ${ }^{51}$ As one of the curators, he was responsible for appointing the German-born physician Paulus Hermann (1646-1695) to become the new botany professor, after the demise of professor Arnold Seyen in 1679. Hermann's assignment was further to cultivate and expand the collection of the hortus, for the "service and splendour" of the garden, as decreed by the curators. ${ }^{52}$

Wanting to live near to the University of Leiden, Beverningh purchased the estate Oud-Teylingen (also known as Lockhorst) in the nearby village of Warmond, in $1675 . .^{53}$ The sale deed stated that the "house included its goods as well as gardens, orchards, planted trees, canals, and waterworks, of about five morgen (ten acres) as measured by land surveyor Jan Douw." ${ }^{54}$ Here, one of the steps Beverningh took to enhance his garden was to collect and cultivate exotic plants.

Beverningh was a keen collector of exotic flora that were sent to him through his various contacts overseas and he acquired herbals and herbaria to further examine and enjoy nature's riches. He had a wide and diverse network, with people from 
HOLLAND'S HORTUS AND BALTIC BOTANY: TRANSFORMING AND TRANSPORTING 'MOTHER

NATURE' ALONG THE 'MOTHER OF ALL TRADES' ROUTE.

the political, the mercantile, and the university arenas. For instance, the diplomat received a parcel of Peruvian seeds while he was involved with peace negotiations with the Spaniards. From his far-flung connections in and transported via the VOC routes he received from Ceylon, Japan, Batavia, Cape of Good Hope plant seeds and exsiccates. He built his estate and collection while simultaneously expanding his botanical connections by sharing his plant specimens and books with others. One of his prized books was an illuminated copy of the Hortus Eystettensis (Nürnberg, 1613), which he bequeathed to the University Library, as a strong token of his involvement as curator and benefactor of the University. ${ }^{55}$

The plants in his garden and his herbaria came from various sources, one of the greatest of which was the botanist Paulus Hermann, from whom he received many specimens. Hermann started his career as a medical officer for the VOC and was stationed in Ceylon in the 1670s. He left Holland in 1672, and travelled to the East via the Cape of Good Hope. During his brief stopover, he was able to collect local flora, which he dried and kept in a herbarium. In Ceylon he worked at the Company's hospital, but he also found time to look into the local plant life. He regularly shipped dried and living plants, drawings, and manuscripts to his contacts in the Low Countries, the Leiden botanical professor Arnold Seyen, merchant-botanist Jan Commelin in Amsterdam, and the statesmen Beverningh and Gaspar Fagel. ${ }^{56}$ During a stay in Batavia he met the VOC apothecary and merchant Andreas Cleyer (1634-1698) and physician Willem ten Rhyne (1647-1700). Ten Rhyne, who we encountered in chapter three, and Cleyer likewise exchanged botanical samples and information with the same set of people: Commelin, Beverningh, Breyne, and Seyen. ${ }^{57}$ Various men, stationed at different locations, made up this network through which Beverningh received his botanical treasures. ${ }^{58}$

By entering Dutch gardens such as Beverningh's, botanists could examine vegetation sent from afar and compare it with known samples, either by using living or dried specimens or verifying it with images printed in herbals. The ongoing accumulation of foreign flora led to a constant adaptation of herb books regarding names, types, and descriptions. Collecting and growing beautiful and practical flowers and vegetation were therefore intricately linked with the assemblage of herbals and herbaria filled with pressed and dried plants. These paper gardens functioned as a type of reference guide to the flora that someone had owned or wanted to own. Beverningh collected not only exotic plants, but also herbaria, herb books, and manuscripts gathered from the various nodes of the Dutch mercantile networks. Bound in separate volumes, these paper gardens formed an intricate part of Beverningh's botanical collection, which he kept in a special leather folder in his library to be used alongside his garden plants..$^{59}$ 
HOLLAND'S HORTUS AND BALTIC BOTANY: TRANSFORMING AND TRANSPORTING 'MOTHER NATURE' ALONG THE 'MOTHER OF ALL TRADES' ROUTE.

The manuscript titled MS. Apparatus Botanicus, qui olim studiis inseaviit visi D. Hieron. Van Beverning, XVII Voll. listed twenty seven herbaria once owned by Beverningh and purchased by the Leiden University in $1741 .{ }^{60}$ It remains uncertain, however, how many herbaria and herbals the statesman possessed during his lifetime. However, for the Leiden University librarian Abraham Gronovius it seemed important enough to purchase this collection for the university from a descendent of Beverningh. The statesman himself never seemed to have compiled a herbarium. Most herbarium-collectors compiled these themselves, as did Paulus Hermann, father and son Breyne, and the English botanist and physician Hans Sloane. Collecting without compiling herbaria underscored Beverningh's position as an amateur-gentleman who took a disinterested attitude towards natural history. He collected and exchanged flora for the sake of leisurely study and enjoyment, while welcoming and sponsoring other amateurs and botanists to share in this pursuit. ${ }^{61}$

The manuscripts purchased for the University may not have contained all the herbaria owned by Beverningh. They nonetheless give an insight into the rich diversity of his collection and his wide network. One found, amongst others, a forty-nine page herbarium of Cape plants collected by Paul Hermann, two volumes of a herbarium of Ceylon plants (totalling 357 pages), a 103-page herbarium of Italian plants, the four volumes of Breyne's Plantae rariones Borussicae et Cassubicae, six folio leaves of exsiccates sent by Andreas Cleyer from Batavia, a herbarium of Mediterranean plants Plantae rariones compiled by the Italian botanist Paolo Boccone, and two different Herbaria vivus collected by Breyne. ${ }^{62}$ Furthermore, the statesman owned two manuscripts written by VOC physician Willem ten Rhyne in Japan, one in Latin on camphor (Differentia Camphora) and a short Dutch text on the maintenance and preparation of tea (Beschrijvinge op wat wijs en manier den Theeboom geraijt en de Thee gemaakt wordt). ${ }^{63}$ This collection enabled Beverningh and those he invited to consult, examine, and compare both familiar and unfamiliar plants and to learn about the uses of exotic herbs. Nature captured on paper either dried or described, enabled repetitive inquiry and discussion on taxonomy. Manifested in these books and manuscripts, a section of Beverningh's accumulated botanical knowledge has remained to the present day, whereas his garden and plants have not.

Beverningh acquired plants not only for his own garden or for his own pleasure. He opened his garden to local and foreign visitors, he arranged specimens to be shipped to the Leiden Hortus Botanicus, and he forwarded samples and drawings to his botanical connections. At times, he organised shipments of bulbs, seeds, or drawings to be sent to his beneficiaries. For instance, around 1667, Beverningh commissioned a shipment of tubers and bulbs of Cape plants to be sent to the Hortus Bo- 
HOLLAND'S HORTUS AND BALTIC BOTANY: TRANSFORMING AND TRANSPORTING 'MOTHER

NATURE' ALONG THE 'MOTHER OF ALL TRADES' ROUTE.

tanicus for the enlargement of Leiden University's collection. Later on, he presented the Hortus with Peruvian plants that he had grown from seed in his garden. ${ }^{64}$

Leiden's Hortus was not Beverningh's only beneficiary. He also received various local and foreign guests, some of whom kept records of their visits that help to give an insight of his collection. Henry Brompton, the Bishop of London, wanted to visit these gardens, since the high-ranked bishop keenly collected botanical samples for his garden. Instead he sent his head gardener George London to go on his behalf in the mid-1680s. As the emissary of Brompton, London was allowed access to a large number of private gardens in the Low Countries and collected samples for his master's garden at Lambeth Palace. Along the way, he listed every specimen he collected, including its finding place. From Oud-Teylingen, London received twentysix plants from mostly the Cape of Good Hope. Later, the English botanist Leonard Plukenet made a diagram of London's findings, arranged according to the garden where London found each sample and with the plants in alphabetical order. He reworked London's records, and in so doing constructed a chart of Dutch gardens that showcased this manipulative relocation of plants.

London had brought hundreds of plants, some of them in larger quantities, back to England. He obtained specimens from the botanical gardens of Leiden and Amsterdam and the garden of the Prince of Orange at Honselaarsdijk, from the gardens of the statesmen Hans Willem Bentinck, Gaspar Fagel, and Hieronymus van Beverningh, and from the merchant Philips de Flines of Haarlem. ${ }^{65}$ London also visited the merchant's widow and amateur Margareta Poulle at Gunterstein near Utrecht, whose grandfather and great-uncle had become wealthy by trading French salt for cereal from Danzig in the beginning of the seventeenth century ${ }^{66}$ Plukenet listed the vegetation shipped from Asia, Africa, and America, since all of these collectors, through their business, various family members and the university, had ties with the VOC. Simultaneously, this list fuelled current historians' understanding that botanical knowledge and material circulated between Holland, Asia, and England due to the linked connections between these regions.

Beverningh's network, however, went beyond this triangle. Amongst his personal contacts he counted the Dutch amateur botanist, merchant and resident of Danzig, Jacob Breyne, who we met in the previous section. Since Beverningh had no direct dealing with the Baltic region, he welcomed this contact to help him expand his collection of flora. The statesman invited Breyne to Oud-Teylingen to examine the exquisite plant collection. In return, he supplied Beverningh with several herbaria of local plants. Breyne visited Oud-Teylingen several times between the 1660s, and 1680 s. 
Beverningh's contacts with VOC physician Willem ten Rhyne could have been established through Jacob Breyne, or via Ten Rhyne's uncle by marriage, Quirinus Bosch, minister to the Reformed Church of in the little village of Warmond. ${ }^{67}$ OudTeylingen connected botanists from various parts of Europe. It is possible that on one of his visits, Breyne met the Italian botanist Paolo Boccone, who also visited OudTeylingen in the 1670s. It was possibly through this mutual acquaintance that Boccone and Breyne corresponded, for Breyne had sent a letter on the characteristics and effects of the ginseng root that Boccone later published in his herbal Museu di Plante rare.$^{68}$ Boccone, in turn, sent Breyne a parcel with plant samples and their names in Latin. ${ }^{69}$ Their mutual interest brought these men together, which led to an exchange of information, and possibly seeds and exsiccates, thereby strengthening the position of each within this network, while it enabled them to further their botanical inquiry.

The statesman had brought nature's treasures together in his garden and library. This demonstrated his ability to control nature, his wealth, his refined taste, and his well connectedness. He opened his estate for others to examine and enjoy, while he gave and obtained specimens, manuscripts, and books through polite exchange. Beverningh used the vast Dutch trade network to obtain exotic flora not only for his collection, but also for the benefit of other gardens and other inquirers into nature. From the Baltic area, Oud-Teylingen received and exchanged botanical matter and knowledge mediated by Jacob Breyne, who, furthermore, translated Beverningh's rich collection into a published herb book: the Centuria.

\section{Breyne and his herbals}

Breyne's merchant status encompassed both trade and botany. His trade brought him regularly to the Low Countries, which enabled him to visit Beverningh's garden on multiple occasions and receive specimens, drawings, and manuscripts from the statesman. He accumulated not only natural knowledge he furthermore produced herbals whereby he combined plants from Beverningh's estate with samples he had found in Danzig, and natural knowledge received from Holland's trading post in Japan. He undertook this knowledge production in his hometown Danzig, aided by Dutch, German, and Polish artisans as will be discussed in this section. Both the way the Exoticarum aliarumque minus cognitarum Plantarum centuria prima was made as well as the knowledge it contained underscored how Breyne's botanical work and the artists he employed were rooted in both Danzig and Holland, and connected to both locations through the mother trade. 
HOLLAND'S HORTUS AND BALTIC BOTANY: TRANSFORMING AND TRANSPORTING 'MOTHER NATURE' ALONG THE 'MOTHER OF ALL TRADES' ROUTE.

Before the merchant published the Centuria he had made notes, gathered plants, and received drawings, and manuscripts from Beverningh. In some cases, the statesman had commissioned the flower painter Stephan Cousijns to produce paintings of plants to be sent to Danzig. In the statesman's collection we find the manuscript Differentia Camphora (in Latin) and a short text in Dutch on the maintenance and making of tea that Beverningh got from Willem ten Rhyne in 1675. From the Dutch outpost on Deshima in Japan, Ten Rhyne also shipped tea seeds and some watercolours to Beverningh, who passed everything on to Breyne for the Centuria. ${ }^{70}$ Breyne further received directly from Ten Rhyne a four-page Latin text on tea. ${ }^{71}$ It remains speculative why the VOC physician sent separate parcels to both men. Possibly it was more convenient to ship goods from Japan to Holland rather then to Danzig.

Based on these drawings of the tea plants "with seeds and fruits" an engraving accompanied the plant's description in the main text. ${ }^{72}$ Breyne attached Willem ten Rhyne's own extensive description on the camphor plant and the tea shrub as a separate appendix, as well as some small notes on Cape plants. The practice of inserting articles written by other authors, occurred on occasion in the Low Countries. For instance, as a closing section to his The Dutch Gardener, Jan van der Groen included physician Peter Nylandt's "The Sensible Gardener, on the Twelve Months of the Year". ${ }^{73}$ And when physician and botanist Stephaan Blankaert posthumously published physician Cornelis Bontekoe's book on the use and misuse of tobacco and tea in 1686 , he included a chapter on coffee that he had written. ${ }^{74}$ In all these cases, the authors' contributions fit the overall theme of the book, that is, on gardening or on the taking of herbs. The compiler might have had financial reasons for including them. It allowed him to broaden the scope and appeal of the herbal.

In the Centuria, Breyne listed rare plants found in Holland next to locally found Polish plants, with their names and appearances. It included furthermore, as stated, Ten Rhyne's extensive contribution on camphor and tea. There were possibly more reasons for Breyne's action. First of all, he wanted to publish Ten Rhyne's observations, but added these texts as an appendix because the main body of text was already set by that time. Secondly, tea had become more widespread in Europe, popularized by returning VOC employees, as did camphor, which raised public interest in them. In Europe there was a growing desire to learn more about the possible medicinal qualities of both camphor and tea, and this Ten Rhyne tried to satisfy. ${ }^{75}$ This could have motivated the merchant to add an appendix with his valued friend's findings. Ten Rhyne was, in Breyne's words "summo amico meo" (my best friend). ${ }^{76}$ Their friendship and their passion for botany firmly linked these two men to their international trade and Ten Rhyne's contribution to the Centuria underscored this close connection, providing therefore one more reason to include it. 
In the Centuria, Breyne gave descriptions of plants from the Far East, the Cape of Good Hope, South America and, to a lesser extent, from the Mediterranean, referring to habitus, appearance, and other published botanical sources. He furthermore introduced a few unusual local plants he had encountered on his trips in the Polish area. ${ }^{77}$ For instance, he included the Caryophylata Montana that grew in his own garden, and the Pulsatilla Polyanthos as his brother Peter Breyne had seen and described it growing near Warsaw. ${ }^{78}$ The Centuria promoted not only exotic plants found in Dutch gardens, it was a way for Breyne to bring the plants growing in the Baltic region to his readers' attention and allow them to compare the uniqueness or similarities of these locally found plants with flora from other parts of the world.

Amongst natural historians and botanists at this time, there was a growing awareness regarding local flora, as Alix Cooper explains in her book Inventing the Indigenous, that paralleled the inquiry into exotic botany. ${ }^{79}$ Breyne wanted to bring the uniqueness of Polish plants to the attention of others, in addition to the growing body of knowledge regarding American, African and Asian flora. From Breyne's perspective his herbaria formed a body of local knowledge, found in his own backyard as it were. From the perspective of his Dutch botanical friends and acquaintances, these plants were just as unfamiliar as 'exotic' flora. These different ways of perceiving what is local and what is exotic was then not very clear-cut. What was local for one collector was exotic for another botanist. Now, Breyne offered the opportunity to compare samples of Polish vegetation with imported flora found in Dutch gardens, while at the same time this motivated him to continue collecting local plants for his herbaria and subsequently contemplate publishing a separate book about it. Since trade had brought him to Danzig, he was able to inquire into the surrounding nature and through his mercantile/botanical network he could tempt others to learn about the (for them) rare local plants. The first introduction happened in the Centuria, but Breyne contemplated publishing another book featuring only Baltic plants.

But first, in 1680, Breyne published his second herb book. The Prodromus fasciculi rariorum plantarum listed more exotic plants he had seen in 1670 in Holland. In the introduction he mentioned visiting the Hortus Botanicus of Leiden and he listed the names of "illustrious and noble men" who helped him to publish this book. Breyne named Beverningh first, followed by statesman Simon van Beaumont, merchant-botanist Jan Commelin in Amsterdam, apothecary Frans van Sevenhuizen of The Hague, and he concluded with silk merchant Philips de Flines of Haarlem, who we met in chapter two ${ }^{80}$ Some of these amateur-botanists had contributed to his first book, but were now individually named. Possibly, he depended less on Beverningh for botanical or monetary resources, or he felt the need to strengthen his ties with other botany amateurs. This catalogue without illustrations presented in alphabetical 
HOLLAND'S HORTUS AND BALTIC BOTANY: TRANSFORMING AND TRANSPORTING 'MOTHER

NATURE' ALONG THE 'MOTHER OF ALL TRADES' ROUTE.

order a plant's name, a short description, in which garden he saw it, and whether the plant flowered, bore fruit or seeds at the time of his observation. Sometimes Breyne also gave the country of origin and referred to other publications when appropriate. In this way he made available to others the exotic rarities of nature growing in the Low Countries. Breyne's herbal represented plants imported into Dutch gardens as well as flora collected and described by VOC servants stationed in various trading posts. Back in Danzig, he catalogued plants, drawings, and descriptions that he had collected in Holland or had received through his mercantile contacts. Through the VOC network and the mother trade, the production and dispersal of natural knowledge in and through Danzig became firmly established.

In 1689 followed the Prodromus [...] secundus with the results of Breyne's 1688 garden trip to the Low Countries. ${ }^{81}$ Possibly while still in Holland in August 1688, he received from the recently returned VOC servant, the gardener Georg Meister a "herbarium of circa 300 paintings of Indian and Japanese vegetation," as well as a collection of seeds and plants. Meister, who also features here in chapter three, had received instructions from his superior Andreas Cleyer in Batavia to deliver this parcel personally to Breyne, "the great amateur of herbs and all vegetation, who at his own expense had it [the Centuria] described and printed." $\$ 2$ Breyne indeed referred to Cleyer's shipment in the Prodromus [...] secundus adding this to his descriptions and depictions of flora he had observed in the Dutch gardens. He furthermore provided additional plant knowledge gathered by his Dutch contacts keeping him informed regarding the failure or success of the growth of shipped seeds and bulbs. ${ }^{83}$ The Danzig merchant-botanist thus gathered and received seeds, drawings, and dried specimens both directly from his contacts in the East and via his Dutch botanical connections. This network of traders, physicians, and amateur botanists allowed him to gather and produce these publications. In 1739, Jacob's son, Johann Philipp Breyne reprinted these two books, added pictures to the discussed plants and published it all as one large volume, which he entitled Prodromi Fasciculi Rariorum Plantarum. ${ }^{84}$

An herbal such as this could only be constructed through the intricate web that Dutch merchants had woven around the world to establish trade and profit. At the same time, it gave rise to a growing influx of exotic plants, seeds, exsiccates, and drawings that furthered natural inquiry and the representational transformation of a plant into a picture. Without the help of go-betweens, Breyne could not have constructed his herb books. Beverningh, Ten Rhyne, his brother Peter Breyne, his botanical friends, Cleyer, Meister, Hermann, and various anonymous servants and local contacts were responsible for supplying him with specimens and plant knowledge. Armed with the collected plants, exsiccates, drawings, descriptions, and other herbals, flora could be identified and categorized. 
Through the production of herbals, unfamiliar flora became more visible and known to others. For this transformative process various artisans reworked plants into drawings and after that into etchings, as will be discussed below. Breyne's publications mirrored this botanically-driven intersection of plants and people along the Dutch trading routes and collected in gardens and libraries. The final transformative act of re-presenting nature as a reproducible image took place in Breyne's hometown Danzig. As described above, this was a city bustling with commerce that attracted traders mainly from the Low Countries. From the late sixteenth century, the Dutch began to settle there and became integrated into Danzig society, fusing trade, art, architecture, book making, and natural inquiry. Breyne could thus draw on locally available resources and residents for the production of his herbals.

\section{Producing knowledge and nature in Danzig}

The merchant-botanist Breyne published his herbals in Danzig, where he had at his disposal several skilled Dutch and Danzig artisans who transformed plants into illustrations. Two local artists, who had previously illustrated the astronomer Hevelius's publication Machina Coelestis, became responsible for the majority of the pictures in the Centuria. ${ }^{85}$ Painter Andreas Stech made plant drawings, which the engraver Isaak Saal turned into etchings. When Breyne began to develop his publication plans, he inquired locally about which illustrators to employ. Possibly Hevelius recommended these artisans to Breyne or the merchant decided to turn to the same artisans after seeing the depictions in the Machina Coelestis.

In the wake of the merchants, some Dutch artists went to live and work in Danzig either temporarily or permanently in search of new markets or patrons. For the Centuria, the Amsterdam engraver Jan Veenhuysen made one print, whereas the Haarlem-born Lambert Visscher etched the title page, after the 1670 design of Stech. ${ }^{86}$ Both Veenhuysen and Visscher must have divided their time between Amsterdam and Danzig between circa 1675-1690 since they worked on both Hevelius's and Breyne's publications. ${ }^{87}$ These books showcased the combined efforts of local and Dutch artists, connected to each other by their Danzig and Dutch patrons, in order to produce examples of natural knowledge.

Historian Inga Söderlund argues that the motivation for choosing a certain artist to make illustrations can vary. The frontispiece had to be elegant and filled with allegorical connotations in order to attract attention. This was the most costly image of the whole book, and usually a famous draughtsman was commissioned for this.$^{88}$ It was not necessary for a reputable painter to reside close to the author in order to cre- 
HOLLAND'S HORTUS AND BALTIC BOTANY: TRANSFORMING AND TRANSPORTING 'MOTHER

NATURE' ALONG THE 'MOTHER OF ALL TRADES' ROUTE.

ate a picture; more important was to have good plant samples at hand. It was practical, however to have an engraver close at hand, as he needed to rework the drawings into etchings. Armed with his etching instruments, and visually aided by the author's collection of dried plants, drawings, or paintings the engraver could produce a printable image of nature.

In Holland, Beverningh commissioned the flower painter Stephan Cousijns to make eight paintings for the Centuria, which he then sent to Breyne. In Danzig, Stech turned these watercolours into a design that Saal then etched onto a copper plate to produce an engraving. ${ }^{89}$ Apparently Breyne did not possess exsiccates, actual specimens, or paintings of every discussed plants. He had to turn to the well-known flower painter to produce these designs, created after specimens found in Dutch gardens. ${ }^{90}$ The mindful work of these skilled artisans and joint efforts of collectors and describers of botany in Holland, Poland, the Cape, and the Far East, enabled Breyne to construct a mobile paper garden, filled with representations of nature's rarities.

Through Breyne and Beverningh's network collectors, physicians, and artisans exchanged plants and paper to further propagate knowledge of nature through observation, collection, description, depiction, and dispersion. Using the trade routes of the VOC and the Moedernegotie, their joint effort enabled the transformation and dispersal of nature, enabling others to become acquainted with local and foreign flora. ${ }^{91}$ Beverningh accumulated herbs and herbals that he and his helpers placed in the house and grounds of Oud-Teylingen. His collection remained there in a fixed location, where visitors could examine and enjoy nature's treasures. Simultaneously in Danzig, Jacob Breyne turned his collection of perishable plants and drawings into a mobile herbal, which brought these herbs into the homes and gardens of its readers.

Transplanted onto paper, these printed gardens allowed for a further dispersal of flora, whereby art rendered nature's rarities into recognizable images with names, descriptions, and references. This transformation could only be achieved through the cooperation of botanists, painters, engravers, and publishers. Through their combined efforts these people recreated nature on paper thereby presenting a visual and verbal language that allowed others to examine and enjoy the herbal. Breyne's publications allowed readers (then and now) to acquaint themselves with local and exotic plants, with their names and appearances, references to other publications, and its characteristics. This transformed nature became a means of communication amongst botanists and amateurs to discuss and determine taxonomy, habitus, and characteristics. The herbal functioned as a reference book that allowed for an exchange of plants and knowledge, so that the readers could negotiate, recognize, acquire, and inquire precious and exotic flora. ${ }^{22}$ 
HOLLAND'S HORTUS AND BALTIC BOTANY: TRANSFORMING AND TRANSPORTING 'MOTHER NATURE' ALONG THE 'MOTHER OF ALL TRADES' ROUTE.

\section{Herbals: from nature to (im)mutable mobiles}

Jointly, the Danzig botanist and artisans changed fragile vegetation taken mostly from Beverningh's estate, with some specimens from other Dutch gardens, and samples Breyne had collected around Danzig into an imperishable and portable garden. The flora featured in the Centuria never withered. Plants, like drawings of coastlines made in the sand, have a limited lifespan. In order to preserve and disperse plant knowledge, botanists produced herbals, or put it in Latourian phrasing: botanists created immutable mobiles, that allowed flora to be seen by distant others, and thus instigated a circulation of knowledge. Latour argues in his article "Visualization and Cognition" that certain subjects (botany, mathematics) needed an etching to go with the description since an image is more stable than a text. ${ }^{93}$ However, both the text and the image contained in an herbal, as will be discussed below, proved in fact to possess great flexibility.

Botanists used multiple herbals by different authors to identify and verify plants, either garden specimens or plants preserved in herbaria. Then, one could add, change, and challenge plants, names, uses, characteristics, and knowledge as found in published herb books. This led to the production of updated or new herbals that brought these findings to the attention of other botanists and amateurs. As historian Johan de Jong explains, in the context of discussing the process of designing ships practiced at the VOC shipyards during the seventeenth and eighteenth centuries, the mobiles involved in such processes had to possess a kind of dynamic stability, which he refers to by claiming that they were simultaneously immutable and flexible. Distinguishing various stages in the process of design, de Jong speaks of constituting "flexible layers of mobiles" that preceded the finished product. ${ }^{94}$ Preceding an herb book, we can likewise trace various 'design' stages or flexible layers of mobiles. Regarding the steady production of botanical books and the growing body of described and depicted natural history, we can argue along the same lines that these books consisted of flexible layers of mobiles. Plants found in fields or cultivated in gardens along with dried specimens in herbaria and reproduced in herbals together formed the basis for the ongoing discussion with and adaptation of existing botanical books. Plants underwent various stages of adaptation, from living, to dried, painted, and etched, before becoming stabilized in reproducible herb books, that in turn, could form a source for other herbals.

Producing an herbal was not a simple fixation of nature into art. So how did Breyne, Stech, and Saal proceed to construct an herbal? Historian Johannes Heniger informs us that after an artist produced a picture, he passed it to an engraver who covered the back of the drawing all over with chalk and placed it on a copper plate. 
HOLLAND'S HORTUS AND BALTIC BOTANY: TRANSFORMING AND TRANSPORTING 'MOTHER

NATURE' ALONG THE 'MOTHER OF ALL TRADES' ROUTE.

He then traced the lines of the drawing with a burin, which left a rough sketch in chalk on the plate. This formed the outline of his etching. ${ }^{95}$ Simply put, from a plant it took two transformative steps to become an image. The production of illustrations could be more complicated, as a botanist might not have the actual plant at hand, or a dried specimen, or a drawing.

To comprehend how this complicated transformative enterprise took shape we briefly turn to the unfinished Herbarium or Kruydboek of the Dutch physician Stephaan Blankaert (1650-1703). Blankaert wrote books on anatomy, medicine, pharmacy, and nutrition. Having published a book on plants found in the Low Countries (Den Nederlandschen Herbarius, Amsterdam, 1698), he decided to publish a book on exotic plants, which he never finished. This manuscript illustrates that an herbal was a combination of existing and new material.

Blankaert's unpublished manuscript consists of five large volumes filled with over 2,300 drawings in ink or pencil of different hands, all of these unsigned. ${ }^{96} \mathrm{He}$ likely did most of the designs himself, just as he did for his other herb book..$^{97} \mathrm{On}$ some pages he combined cut-out flower prints with drawn stems and leaves. In his handwriting we find the name of each plant in Latin and sometimes in more languages, some pages were left blank, either with a name and no image, or vice versa. Blankaert listed the plants he wanted in his herbal. However, sometimes he received pictures of exotic vegetation that he had to name afterwards. There were differences in style of depicting showing either just a twig with leaves and flowers, or a whole plant with roots and all. [see picture 4.5]

The manuscript presents us with an insight into the enormity of such a project and the many hands that helped to compose this catalogue of nature's riches. Possibly some drawings were sent to him directly from the Far East, either through Andreas Cleyer or his contact Willem ten Rhyne. ${ }^{98}$ Blankaert used drawings that an engraver would then turn into an etching by blackening the back of the paper, then placing and tracing the drawing onto the plate. ${ }^{99}$ The botanist in some cases used (parts of) existing images and added stems and leaves in order to present a more complete plant. He combined not only existing texts with his own suggestions, he furthermore combined his drawings with images of others.

Blankaert's Kruydboek nuances Latour's argument regarding the immutability of descriptions and depictions, since he mutated both to produce an herb book. Based on the accumulation and mutation of matter and knowledge, publications, once printed, became immutable. In turn, these books allowed for a further mutation and interpretation of botanical data, or flexible layers of mobiles. An herbal mapped the botanical world, presenting the reader with new discoveries, adjusted names and so forth. Historian Staffan Müller-Wille argues such a case using Linneaus's 
HOLLAND'S HORTUS AND BALTIC BOTANY: TRANSFORMING AND TRANSPORTING 'MOTHER NATURE' ALONG THE 'MOTHER OF ALL TRADES' ROUTE.

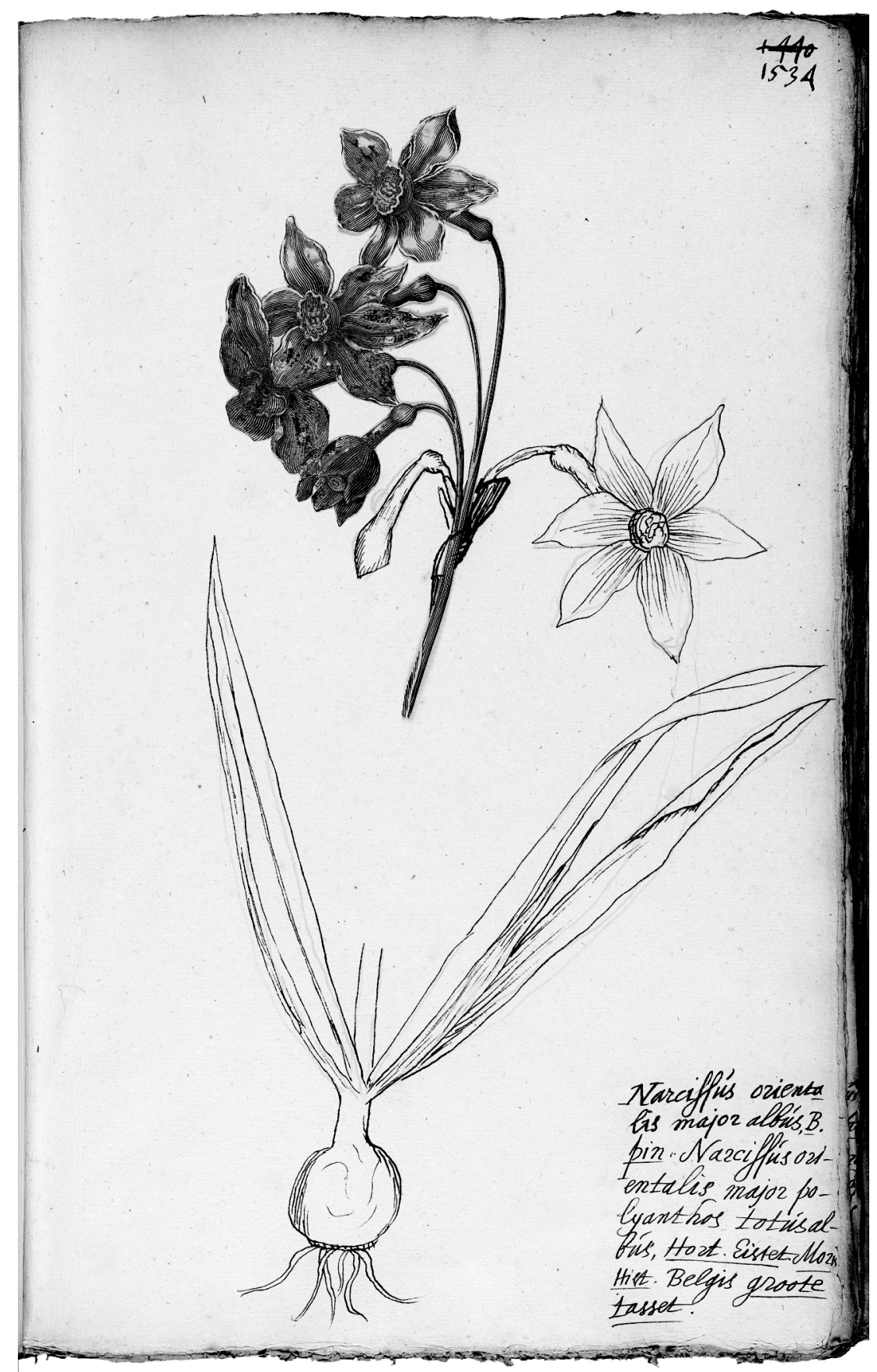

4.5) Stephaan Blankaert, Kruydboek, Koninklijke Bibliotheek, Den Haag. 
HOLLAND'S HORTUS AND BALTIC BOTANY: TRANSFORMING AND TRANSPORTING 'MOTHER

NATURE' ALONG THE 'MOTHER OF ALL TRADES' ROUTE.

herbal, writing that a publication embodied the plants and knowledge that botanists exchanged, rather than being a representation of a centre of accumulation, i.e. a garden. Blankaert, as well as Breyne, indeed relied on the exchange of paper and plant matter for the production of his work, thereby adding that what he found, collected, or grew in gardens where he lived. By combining this accumulated knowledge and nature he could transform it into a manuscript in order to render it stable, and thus contribute to this growing body of natural knowledge.

These botanists, thus, used existing literature and nomenclature to identify and classify plants. They tried to fit in unfamiliar vegetation by comparing new specimens with what was known, giving Latin and vernacular names based on the plant's appearance, and change or adapt names and knowledge presented by other botanists. In the seventeenth century we see how established literature, such as the books by Bauhin, Morrison, and others laid the foundation to further natural knowledge and motivate expeditions to collect unknown specimens. And with the collective efforts of merchants, botanists, amateurs, and artisans who transformed plants and knowledge into books, this research, made up of flexible layers of mobile herbs, herbaria, and herbals, further flourished to present new insights, illustrations, categorizations, and nomenclature, without radically altering the methods of inquiry and the ways of transformation and presentation.

Blankaert's manuscript showed the cooperative process of collecting and transforming nature and existing herbals while at the same time the process removed nature from its source. Reworked into an image, nature could be preserved, studied, discussed, and compared. Making an herbal, thus, was an example of a hybrid act of hands and minds that jointly furthered natural knowledge. ${ }^{100}$ The finished herbal functioned as a catalogue of known flora, with names written in multiple languages for reference, thus helping the reader to inquire further into and become more familiar with nature.

Nature was presented in a way that allowed clear communication amongst botanists and amateurs as Margocsy explains. ${ }^{101}$ It provided the reader with detailed descriptions and depictions of plant, their various stages of growth and fruit, where they grew, how to cultivate them, and their taxonomy. All herbals, such as the Centuria, listed the botanical books the author had used for reference. This presented a pedigree that projected the authority and trustworthiness of the author and his book, while it enabled communication between amateurs and botanists and propagated the botanist's deep understanding of nature's workings. Indeed, as historian Brian Ogilvie states, an herbal could criticise, add, adapt, or refer to earlier published herbals and thus make itself indispensible for communicating between the different botanists and amateurs. ${ }^{102}$ 
With each entry, the compiler presented a name; sometimes he added a name in the vernacular or in other languages or even introduced a new or adapted name. This could then be picked up by a wider audience and used as a means to further classify a plant. There was furthermore an ongoing discussion regarding cataloguing flora. Paulus Hermann and Jacob Breyne, as mentioned above, followed the morphological classification introduced by Robert Morrison, while using Bauhin's suggested names. Published herbals then were a source of discussion on how to explain and order nature, which motivated amateurs and botanists to continue the pursuit of natural inquiry and produce updated herbals, which made these books mobile but not entirely immutable.

Quite apart from and at the same time next to its scientific value, a reader could enjoy an herbal as a representation of nature, forever blooming and fresh. Professor of botany Abraham Munting of the University of Groningen, promoted in the introduction of his 1696 herb book Nauwkeurige beschryving der aardgewassen that an herbal should give pleasure to "[t]hose who do not have gardens" and use his book to foster "the rarities of Nature regarding various plants; the printed images will provide for an optical garden in their homes." 103 It motivated an enthusiastic inquiry into nature and led one to "learn to know God and Nature [...and...] understand Nature's hidden powers" from the comfort of one's own home and garden. ${ }^{104}$

The ongoing inquiry into nature, the pursuit of 'exotic' and 'local' botany led to the construction of gardens, herbaria, and herb books. This transformation of nature into art, whereby botanists combined and compared known and unfamiliar flora and literature, saw an increased production of updated herbals filled with new plants and new insights. Inquirers into nature, then, could pursue botany by roaming through both a private garden and a paper garden. For producers and consumers, these two sites of intersection jointly formed fertile soil for further natural inquiry. One allowed for the enjoyment and examination of nature that was mutable and fixed on one location: a garden. The other allowed for the contemplation and manipulation of nature that was flexible and mobile: the herbal. Neither site could be constructed without the other, nor without the vast network of suppliers, artisans, describers, patrons, and botanists who jointly transformed nature to render it either temporarily or permanently stable for others to see.

\section{Conclusion}

For a period of circa twenty years Beverningh's estate was a site of inventive intersection in the production and consumption of natural knowledge. Here visitors, 
HOLLAND'S HORTUS AND BALTIC BOTANY: TRANSFORMING AND TRANSPORTING 'MOTHER

NATURE' ALONG THE 'MOTHER OF ALL TRADES' ROUTE.

plants, pictures, and knowledge entered, transformed, left, and re-entered. Beverningh's botanical passion connected politicians, merchants, physicians, gardeners, artisans, and botanists in the Low Countries, in Asia, and in the Baltic area. Part of his legacy remains, though the garden no longer exists. Time, changing ownership, and changing fashion led to the estate's demise. In 1774, circa seventy years after his wife's death, a leaflet advertised a sale at Oud-Teylingen of all kinds of trees, fruits, herbs, and flowers, totalling over 7,000 specimens. ${ }^{105}$ The new owners, who in 1770 bought the estate from a relative of Beverningh, sold the plants to make way for a new garden style that demanded a different design and other sorts of vegetation. ${ }^{106}$ This underscored the temporary character of the garden, in which plants died and new owners cleared the terrain.

Part of Beverningh's herbarium collection has survived in the National Herbarium in Leiden, whereas his garden plants are represented in Breyne's herbals. The alteration of nature into art expanded a plant's life, rendering it stable and mobile. The combined activities of gardening, collecting, and producing herbals led to a movement away from nature, while it simultaneously allowed for a dispersion of nature which again fuelled the inventive inquiry into nature. Transplanted into a paper garden or relocated to other sites by botanists, gardeners, and artisans in Holland and Danzig, Beverningh's collection of plants and botanical information were kept alive for extended examination and enjoyment.

The Polish, German, and Dutch-Danzig transformers of nature jointly constructed botanical books. These mobile paper gardens reached a greater audience and introduced to them to the various Asian, Polish, and Cape plants gathered and described by Breyne. The mutable and immobile garden allowed only a limited number of visitors who could enjoy only a certain number of vegetation per season or period. However, at both sites of intersection, skilful botanists and mindful artisans cooperatively changed elements of nature from a previously unseen or unfamiliar specimen to a cultivated and displayed plant in a garden, a dried herbarium sample, a drawing, and an engraving. This hybrid activity where the mind and hand shaped and contemplated nature consisted of different layers of flexible mobiles. The garden, then, was a temporary and fixed intersection where nature study and exchange took place, and the herb book was a permanent and mobile intersection that enabled an ongoing inquiry into botany, both geographically and over time.

This chapter argues that there along various mobile and stable nodes and intersections natural knowledge was produced and consumed. The mother of all trades linked Beverningh's garden and plant collection at Oud-Teylingen to the herbaria and herbals filled with exotic and Polish plants compiled by Breyne in Danzig. Paral- 
leling commercial trade was the 'trade' of natural knowledge. The vast shipping network connected Holland, the Baltic region, to Asia, Africa, and America transporting and transplanting people and plants. Amateurs, botanists, merchants, physicians, gardeners, and artists exchanged elements of nature and transplanted this firmly in contexts such as gardens and herbals thereby allowing others to examine and enjoy nature's treasures. Art and inquiry jointly reworked natural knowledge into different objects of study and delight. This transformative process took place at Beverningh's garden and Danzig in particular, while at the same time it brought together the $\mathrm{Mo}$ edernegotie and 'Mother Nature'.

In the seventeenth century pursuing natural knowledge and manipulating nature were two faces of the same coin, albeit with institutional and socio-cultural distinctions. This tandem of inquiry and artistic invention was not confined to one garden, one herb book, one region, one country, or one institution or academy, or initiated by one (disinterested) person. Nor was the production and consumption of knowledge solely based on the interactions between the Dutch, French, and English even though the enormous quantities of correspondence might seem to justify this notion. Nor should this pursuit be solely seen as dominated by those involved with the VOC - its physicians, apothecaries, commanders, and gardeners stationed in trading posts in Asia and the Cape of Good Hope. To sum up, the hybrid act of knowledge production and consumption should not be broken down into today's categories of 'science' (the works of the mind) and 'technology' (the works of the hand) and then used as a way to explain and validate history, its actors, their inventions, and their inquiries.

The geography of the history of botany, as this chapter shows, exposed the mercantile route with the Baltic region along which natural knowledge moved and was not confined to the, historically more familiar, VOC routes to Africa and Asia. Commerce and knowledge shared the same paths of transportation and connected different centres, regions, and networks. Dutch trade routes connected the different sites of intersection and it enabled others to become acquainted with foreign flora rendered stable by Danzig and Dutch artists and botanists. Here, botanical knowledge and matter from exotic regions and found locally were combined with familiar herbs and existing literature. This mutation of nature and knowledge allowed a wider audience of contemplators and manipulators to foster nature's riches. The cultivation of flora in gardens and the transformation of herbs into paper gardens were intricately linked to the mother of all trades and was not only in Holland and Asia, that consumers and producers of knowledge teamed and in order to exchange, understand, transform, and disperse precious plants transported from exotic places such as Deshima, Batavia, and the Cape of Good Hope. Breyne and his artisans added locally found flora 
HOLLAND'S HORTUS AND BALTIC BOTANY: TRANSFORMING AND TRANSPORTING 'MOTHER

NATURE' ALONG THE 'MOTHER OF ALL TRADES' ROUTE.

to the growing body of botanical knowledge to produce an herbal that combined and displayed plants received from Beverningh and Holland's trading posts. With the Centuria, Breyne connected the local with the global thereby introducing Danzig as a site of botanical intersection. 
HOLLAND'S HORTUS AND BALTIC BOTANY: TRANSFORMING AND TRANSPORTING 'MOTHER NATURE' ALONG THE 'MOTHER OF ALL TRADES' ROUTE.

1 Jacob Breyne, Exoticarum aliarumque minus cognitarum Plantarum centuria prima (Danzig: David-Fridericus Rhetius, 1678). "Summi inprimis ac faventissimi Maecenatis nostri, Illustrissimi atque Excellentissimi Domini, DN. Hieronymi à Beverningk adjumento ad me deveniret..."

2 Johannes Heniger, Hendrik Adriaan van Reede tot Drakenstein (1636-1691) and Hortus Malabaricus; a contribution to the history of Dutch colonial botany, (Rotterdam/Boston: A.A. Balkema, 1986); Londa Scheibinger, Plants and Empire, Colonial Bioprospecting in the Atlantic World, (Cambridge/London: Harvard University Press, 2004); Claudia Swan, "Collecting Naturalia in the Shadow of Early Modern Dutch Trade," Londa Schiebinger and Claudia Swan (eds), Colonial Botany, Science, Commerce, and Politics in the Early Modern World, (Philadelphia: University of Pennsylvania Press, 2005), pp. 223-236; D.O. Wijnands, The Botany of the Commelins (Rotterdam: A.A. Balkema, 1983); Wolfgang Michel, "Far Eastern Medicine in Seventeenth and Early Eighteenth Century Germany," Studies in Languages and Cultures, 20 (2005), pp. 67-82.

3 H.A. Bosman-Jelgersma, Vijf eeuwen Delftse Apothekers, (Amsterdam: Ronald Meesters, 1979); D.A. Wittop Koning, De Handel in Geneesmiddelen te Amsterdam tot omstreeks 1637, (Purmerend: J. Muusses, 1942); E. Grendel, De ontwikkeling van de artsenijbereidkunde in Gouda tot 1865, (Gouda: Oudheidkundige Kring "Die Goude", 1957); D.O. Wijnands, E.J.A. Zevenhuizen and J. Heniger, Een Sieraad voor de Stad, de Amsterdamse Hortus Botanicus 1638-1993, (Amsterdam: Amsterdam University Press, 1994), pp. 70-74; Ch. Henriëtte Andreas, In en om een botanische tuin: Hortus Groninganus 1626-1966, (Groningen: Erven B. van der Kamp, 1976).

4 A.G. Morton, History of Botanical Science, an account of the development of botany from ancient times to the present day, (London/New York/Toronto: Academic Press, 1981); Agnes Arber, Herbals their Origin and Evolution, a Chapter in the History of Botany 1470-1670, (Darien: Hafner Publishing Co, 1970); Brian Ogilvie, The Science of Describing, Natural History in Renaissance Europe, (Chicago/London: The University of Chicago Press, 2008). 5 Alix Cooper, Inventing the Indigenous, Local Knowledge and Natural History in Early Modern Europe, (Cambridge/New York: Cambridge University Press, 2007).

6 Daniel Margocsy, “'Refer to folio and number': Encyclopedias, the Exchange of Curiosities, and Practices of Identification before Linnaeus," Journal of the History of Ideas, 71 (2010), pp. 63-89.

7 Klaas van Berkel, "Een onwillige mecenas? De rol van de VOC bij het natuurwetenschappelijk onderzoek in de zeventiende eeuw," J. Bethelem and A.C. Meijer (eds), VOC en Cultuur, (Amsterdam: Schiphouwer en Brinkman, 1993), pp. 39-58; Harold J. Cook, "Global Economies and Local Knowledge in the East Indies; Jacobus Bontius Learns the Facts of Nature," Londa Schiebinger and Claudia Swan (eds), Colonial Botany, Science, Commerce, and Politics in the Early Modern World, (Philadelphia: University of Pennsylvania Press, 2005), pp. 100-118.

8 On plants growing in Dutch gardens and fields: Abraham Munting, Nauwkeurige beschryving der aardgewassen, waar in de veelerley aarten bijzondere Eigenschappen der Boomen, Heesters, Kruyden, bloemen, (Leiden: Pieter van der Aa, 1696); Abraham Munting, Waare Oeffening der Planten, (Amsterdam: Jan Rieuwertsz, 1682). On the garden of Gaspar Fagel: Hortus Regius Honselaerdicensis, Florence, Bibliotheca Nazionale, MS. Pal. 6.B.B.5 (G.F. 182) On the Amsterdam Botanical garden: Jan Commelin, Hortus Medicus Amstelodamen- 
HOLLAND'S HORTUS AND BALTIC BOTANY: TRANSFORMING AND TRANSPORTING 'MOTHER

NATURE' ALONG THE 'MOTHER OF ALL TRADES' ROUTE.

sis, (Amsterdam: P. \& J. Blaeu, 1697); and the published catalogues of the Leiden Hortus by professors Florentius Schuyl and Paulus Hermann. For further reading: Erik de Jong, Natuur en Kunst, Nederlandse tuin- en landschapsarchitectuur 1650-1740, (Hilversum: Toth, 1995) where he discusses books and poems on Dutch public and private gardens.

9 The region around the free city of Danzig was known as Pomerania or Kashubia, and fell under the Kingdom of Poland. Today Danzig is known as Gdansk, Poland. In the seventeenth century the free city of Danzig housed a mixture of Polish, German/Prussian, and Dutch inhabitants.

${ }^{10}$ Staffan Müller-Wille, "Joining Lapland and the Topinambes in Flourishing Holland: Center and Periphery in Linnaean Botany," Science in Context, 16 (2003), pp. 461-488.

${ }^{11}$ On the botanical connections between Holland and England, see: D.O. Wijnands, "Hortus auriaci: de tuinen van Oranje en hun plaats in de tuinbouw en plantkunde van de late zeventiende eeuw/Hortus auriaci: the gardens of Orange and their place in late 17th-century botany and horticulture," Journal of Garden History, 8 (1988), pp. 61-86.

${ }^{12}$ Milja van Tielhof, De Hollandse graanhandel, 1470-1570. Koren op de Amsterdamse Molen, (Den Haag: Hollandse Historische Reeks, 1995) vol. 23. See chapter 5 where Tielhof describes the rise of the cereal trade between Danzig and Holland, with detailed tables and figures, pp. 86-106.

${ }^{13}$ Brick functioned mostly as cheap ballast-cargo, which the Danzig inhabitants used as building material for their houses.

${ }^{14}$ See for the transfer of collections of Albertus Seba and Frederik Ruysch to Russia: Luuc Kooijmans, De doodskunstenaar; De anatomische lessen van Frederik Ruysch, (Amsterdam: Bert Bakker, 2004), pp. 314-326; and also Ellinoor Bergvelt and Renée Kistemaker (eds), De wereld binnen handbereik. Nederlandse kunst- en rariteitenverzamelingen, 1585-1735, (Zwolle/Amsterdam: Waanders, 1992); For the dispersion of charts and windmills see: C.A. Davids, "On the diffusion of nautical knowledge from the Netherlands, 1550-1850," W.G. Heeres, L.M.J.B. Hesp, L. Noordegraaf and R.C.W. van der Voort (eds), From Dunkirk to Danzig, Shipping and trade in the North Sea and the Baltic, 1350-1850, (Hilversum: Verloren Publishers, 1988), pp. 217-236; C.A. Davids, "The transfer of Windmill Technology from the Netherlands to North-Eastern Europe from the $16^{\text {th }}$ to the Early $19^{\text {th }}$ Century," J.Ph.S. Lemmink and J.S.A.M. van Koningsbrugge (eds), Baltic Affairs, Relations between the Netherlands and North-eastern Europe 1500-1800, (Nijmegen: INOS, 1990), pp. 33-52. And the connection between Holland and Sweden: Wilfrid Blunt, Linnaeus; The Compleat Naturalist, (London: Frances Lincoln, 2004); Christina Skott, "The VOC and Swedish natural history: The transmission of scientific knowledge in the eighteenth century," Siegried Huigen, Jan L. de Jong and Elmer Kolfin (eds), The Dutch tranding Companies as Knowlegde Networks, (Leiden/Boston: Brill, 2010), pp. 361-392.

15 Jan de Vries and Ad van der Woude, Nederland 1500-1815, De eerste ronde van moderne economische groei, (Amsterdam: Balans, 2005), pp. 482-485. Danzig was an important harbour for the cereal trade to Holland, with profits of circa one million guilders per annum; see also: M. Bogucka, "Dutch Merchants' Activities in Gdansk in the First Half of the $17^{\text {th }}$ Century," J.Ph.S. Lemmink and J.S.A.M. van Koningsbrugge (eds), Baltic Affairs, Relations between the Netherlands and North-eastern Europe 1500-1800, (Nijmegen: INOS, 1990), pp. 19-32. 
${ }^{16}$ Apart from the already mentioned books by Lemmink and van Koningsbrugge (eds), Baltic Affairs and Heeres, Hesp, Noordegraaf and van der Voort (eds), From Dunkirk to Danzig see also: Jonathan Israel, The Dutch Republic, Its Rise, Greatness, and Fall 14771806, (Oxford: Clarendon Press, 1995); Maarten Prak, Gouden Eeuw. Het raadsel van de Republiek, (Nijmegen: SUN, 2002); A.Th. van Deursen, De last van veel geluk, De geschiedenis van Nederland 1555-1702, (Amsterdam: Bert Bakker, 2004); Milja van Tielhof, The 'mother of all trades'. The Baltic grain trade in Amsterdam from the late 16th to the early 19th century, (Leiden/Boston/Cologne: Brill Publishers, 2002). And the following websites: http://www.soundtoll.nl/literatuur.php; http://www.geheugenvannederland.nl/?/nl/collecties/ de_nederlandse_oostzeehandel_in_de_periode_1600-1850/bibliografie.

${ }_{17} \bar{S}$ See also note $\overline{2}$ for litterature; Harold J. Cook, Matters of Exchange, Commerce, Medicine, and Science in the Dutch Golden Age, (New Haven/London: Yale University Press, 2007); Richard Grove, "Indigenous Knowledge and the Significance of South-West India for Portuguese and Dutch Constructions of Tropical Nature," Modern Asian Studies, 30 (1996), pp. 121-143; José Antonio Gonsalves de Mello, Nederlanders in Brazilië (1624-1654), de invloed van de Hollandse bezetting op het leven en de cultuur in Noord-Brazilië, ed. B.N. Teensma, (Zutphen: Walburg Pers, 2001); Maria Angélica da Silva and Melissa Mota Alcides, "Collecting and Framing the Wilderness: The garden of Johan Maurits (1604-79) in North-East Brazil," Garden History, Journal of the Garden History Society, 30 (2002), pp. 153-176. And see also chapter 3 of this dissertation on the exchange of local and exotic knowledge and nature.

${ }^{18}$ See for more on the Baltic trade note 16 and also: Remmelt Daalder, Els van Eyck van Heslinga, J. Thomas Lindblad, Peter Rogaar and Peter Schonewille (eds), Goud uit Graan; Nederland en het Oostzeegebied 1600-1850, (Zwolle: Waanders Uitgevers, 1998).

19 J. Th. Lindblad, "Evidence of Dutch-Swedish Trade in the $17^{\text {th }}$ Century," in: Lemmink and Van Koningsbrugge, Baltic Affairs, pp. 205-228.

${ }^{20}$ See for the Russian-Dutch connection: Jozien Driessen, Tsaar Peter de Grote en zijn Amsterdamse vrienden, (Utrecht/Antwerpen: Kosmos-Z\&K Uitgevers, 1996). For instance Nicolaas Bidloo moved to Russia to become Peter the Great's physician. He later founded a hospital and botanical garden in Moscow.

${ }^{21}$ Van Tielhof, De Hollandse graanhandel, p. 178.

${ }^{22}$ Van Tielhof, The 'mother of all trades', p. 175.

${ }^{23}$ F.C. Berkenvelder, "Some unknown Dutch archivalia in the Gdansk (Danzig) archives," in: Heeres, Hesp, Noordegraaf and Van der Voort From Dunkirk to Danzig, pp. 145-166, p. 162.

24 The astronomer has received the attention of various historians over the years, see: Eugene Fairfield MacPike, Hevelius, Flamsteed, and Halley: Three Contemporary Astronomers and Their Mutual Relations, (London: Taylor \& Francis, 1937); Steven Shapin, A Social History of Truth; Civility and Science in Seventeenth-Century England, (Chicago/London: The University of Chicago Press, 1994), notably chapter six "Knowing about People and Knowing about Things: A Moral History of Scientific Credibility," pp. 243-309; Mario Biagioli, Galileo's Instruments of Credit: Telescopes, Images, Secrecy, (Chicago: University of Chicago Press, 2006); Voula Saridakis, "Establishing an astronomical network from Danzig: Johannes Hevelius' exchange with the European scientific community," M. Kokowski (ed), The Global and the Local: The History of Science and the Cultural Integration of Europe, Proceedings 
HOLLAND'S HORTUS AND BALTIC BOTANY: TRANSFORMING AND TRANSPORTING 'MOTHER NATURE' ALONG THE 'MOTHER OF ALL TRADES' ROUTE.

of the 2nd ICESHS (Cracow: 2008) pp. 228-232. Electronically available: www.2iceshs.cyfronet.pl/2ICESHS_Proceedings/Chapter_10/R-2_Saridakis.pdf. Historian Londa Schiebinger has touched on Elisabeth's life as the first woman astrologer, her dedication to her husband and his publications and claims that Elisabeth's passion for astronomy was the main reason to marry Hevelius. Londa Schiebinger, "Maria Winkelmann at the Berlin Academy: A Turning Point for Women in Science," Isis, 78 (1987), pp. 174-200, notably pp. 194-5.

${ }^{25}$ Janet Vertesi, "Instrumental images: the visual rhetoric of self-presentation in Hevelius's Machina Coelestis," British Society for the History of Science, 43 (2010), pp. 209-243, notably pp. 220-228.

${ }^{26}$ Christiaan Huygens, Oeuvres complètes de Christiaan Huygens, (Den Haag: Société Hollandaise des Sciences, 1888-1950), vol. 1, pp. 411-412.

${ }^{27}$ Harold Cook argues along same lines in his unpublished paper "Capitalism and Science in the Dutch Golden Age."

${ }^{28}$ Charles van den Heuvel, 'De Huysbou' a reconstruction of an unfinished treatise on architecture, town planning and civil engineering by Simon Stevin, (Amsterdam: Edita, 2005), notably p. 73; B. Woelderink, "Het bezoek van Simon Stevin aan Dantzig in 1591," Tijdschrift voor de geschiedenis der Geneeskunde, Natuurwetenschappen, Wiskunde en Techniek, 3 (1980), pp. 178-186. Peter Furhing (ed.), De wereld is een tuin; Hans Vredeman de Vries en de tuinkunst van de Renaissance, (Gent/Amsterdam: Ludion, 2002).

${ }^{29}$ See also: http://www-history.mcs.st-and.ac.uk/Biographies/Hevelius Koopman.html. For Polish in the service of the VOC, see Roelof van Gelder, Het Oost-indisch avontuur, Duitsers in dienst van de VOC, (Nijmegen: SUN, 1997), pp. 54-55.

${ }^{30}$ Eymert-Jan Goossens and Koen Ottenheym (eds.), Tilman van Gameren (1632-1796), Een Nederlandse architect aan het hof in Polen, (Amsterdam: Stichting Koninklijk Paleis Amsterdam, 2002), pp. 34-37.

${ }^{31}$ Allgemeine deutsche Biographie \& Neue deutsche Biographie (Digitale Register) http://daten.digitale-sammlungen.de/0001/bsb00016320/images/index.html? fip=193.174.98.30\&id= 00016320\&seite=762 Pieter van der Star (ed.), Fahrenheit's Letters to Leibniz and Boerhaave, (Amsterdam: Rodopi, 1984).

${ }^{32}$ For more on the topic of centres of accumulation see: Lissa Roberts (ed), Centres and cycles of accumulation: Material and Knowledge production and exchange in and around the Netherlands during the early modern period (forthcoming).

${ }^{33}$ Jos Kuijlen, "De Danziger Botanicus en Koopman Jacob Breyne (1637-1697) en zijn betekenis voor de Hollandse Plantkunde," Tijdschrift voor de Geschiedenis der Geneeskunde, Natuurwetenschappen, Wiskunde en Techniek, 5 (1982), pp. 116-118. Kuijlen's little biography lacks any references and notes. For additional information, see Breyne's vita in Jacob Breyne and Johann Breyne, Prodromus Fasciculi Rariorum Plantarum, Primus et Secundus (Danzig: Thom. Joh. Schreberi, 1739).

${ }^{34}$ Cook, Matters of Exchange, pp. 321-323. And see: Kuijlen, "De Danziger Botanicus en Koopman Jacob,” pp. 116-118.

${ }^{35}$ Mary Gunn and Enid du Plessis, The Flora Capensis of Jakob and Johann and Philipp Breyne, (Johannesburg: The Brendhurst Press, 1978), p. 21.

${ }^{36}$ Regionaal Archief Leiden, DTB Nederlands Hervormd Ondertrouw (1575-1795), folio $\mathrm{Q}-138 \mathrm{v}$ 
HOLLAND'S HORTUS AND BALTIC BOTANY: TRANSFORMING AND TRANSPORTING 'MOTHER NATURE' ALONG THE 'MOTHER OF ALL TRADES' ROUTE.

${ }^{37}$ Helmut Roob and Cornelia Hoff, Jacob und Johann Philipp Breyne, zwei Danziger Botaniker im 17. und 18. Jahrhundert, (Gotha: Veröffentlichungen der Forschungsbibliothek Gotha, 1988) vol. 27, p. 10.

38 Jan Noordegraaf, “Omtrent Bronnen, Lambert ten Kate schrijft naar Dantsig Brieven aan Johann Philipp Breyne,” De Achttiende Eeuw, 39 (2007), pp. 96-101, p. 97. The Amsterdam merchant and druggist Joan Brayne (ca 1634-1693) was a cousin of Breyne's father Jacob. Brayne lived at the Singel; Bergvelt and Kistemaker, De wereld binnen handbereik, 315. He owned a large and important collection of naturalia; Roob and Hoff, Jacob und Johann Philipp Breyne, pp. 95-97, and 110.

39 Jacob Breyne, Herbarius vivus, 2 vol., Nationaal Herbarium Leiden.

${ }^{40}$ Jacob Breyne, Plantae rariones Borussia et Cassubia (S. Pomeranicae) a Jac. Breynio Gedan. coll., arte en siccatae; atque in libris quatuor studio non eo que debebant ondine positae, et per nomina Bauhiniana explicatae A. 1673 pagg. 77, 4 voll. This is an incomplete manuscript with various plants gone missing, Nationaal Herbarium Leiden.

${ }^{41}$ J.E. Dandy, The Sloane Herbarium, an annotated list of the Horti Sicci composing it: with biographical accounts of the principal contributors, (London: British Museum, 1958), p. 97: there is a MS. list by Petiver headed "Prussian and Cassubian Plants sent me from tht [sic] Celebrated Botanist Jac. Breynius of Dantzick." These are referred to by Petiver in the letter above quoted and by Breynius in a long (undated) letter (S1. MS 4066, f. 271) in which he asks Petiver not to publish them "because I do design and figure them myself for the publique." See also: British Library: S1. MS 4066, f. 271, Breyne to Petiver: "I am now fully resolved to publish my Viridarium of Prussia \& Cassubia, as soon as ever I [...] take a journey one summer more through Prussia \& Cassubia to take a view and reckonize those plants which I had determined to have this year and had made some beginning too with with [sic] wonderfull success as to the observations tho' my health was not answerable to succeed for it...."

${ }^{42}$ Anke te Heesen, "Accounting for the Natural World, Double-Entry Bookkeeping in the Field,” in: Schiebinger and Swan, Colonial Botany, pp. 237-251, p. 240.

${ }^{43}$ Breyne refers to Robert Morison's work in the introduction of the Centuria.

${ }^{44}$ Müller-Wille, "Joining Lapland and the Topinambes," pp. 461-488.

45 The Pinax of 1623 listed circa 6,000 plants names. On the use of Bauhin's Pinax, see: Ferry Bouman, Bob Baljet and Erik Zevenhuizen (eds) Kruidenier aan de Amstel, De Amsterdamse Hortus volgens Johannes Snippendaal (1646), (Amsterdam: Amsterdam University Press, 2007), p. 121; Daniel Margocsy, “'Refer to folio and number',” pp. 63-89; Brian W. Ogilvie, "The Many Books of Nature: Renaissance Naturalists and Information Overload," Journal of the History of Ideas, 64 (2003), pp. 29-40, p. 39.

${ }^{46}$ Margocsy, "Refer to folio and number'," pp. 63-89.

${ }^{47}$ Roob and Hoff, Jacob und Johann Philipp Breyne, p. 77.

${ }^{48}$ In the seventeenth century Beverningh was also spelled Beverningk and Beverning. See for more on Beverningh's statesmanship: G.D.J. Schotel, Iets over Hieronymus van Beverningh en Bruno van der Dussen, (Den Bosch: Gebr. Muller, 1847). F.W.C.P. van Bylandt, Het diplomatisch beleid van Hieronymus van Beverningk, gedurende de jaren 1672-1678, (Den Haag: H.J. Gerretsen, 1863).

${ }^{49}$ Archief van curatoren der Leidsche Universiteit ( -1815) AC 1 6-7. 6, fol. 18, University Library Leiden. 
HOLLAND'S HORTUS AND BALTIC BOTANY: TRANSFORMING AND TRANSPORTING 'MOTHER NATURE' ALONG THE 'MOTHER OF ALL TRADES' ROUTE.

${ }^{50}$ P.C. Molhuysen, Bronnen tot de Geschiedenis der Leidsche Universiteit, 18 febr. $1682-8$ febr. 1725, (Den Haag: Martinus Nijhoff, 1920), pp. 37-38, and p. 42.

${ }^{51}$ Ibid., p. 45; and also: W.K.H. Karstens, H. Kleibrink, De Leidse Hortus, een botanische erfenis, (Zwolle: Uitgeverij Waanders, 1982), p. 31.

${ }^{52}$ Molhuysen, Bronnen tot de Geschiedenis, appendix p. 15, "dat hy oock vlijtigh sal toesien, dat alle de voors. planten, boomen etc met behoorlycke ordre ende voorsorge werden gemanieert en gecultiveert, oock tsijner tijd geplant, verplant ende voortgeset tot den meesten dienst en luyster..." Today, part of the Hortus has been restored to its 17 th century appearance.

${ }^{53}$ Some sources suggest that he lived there in 1673; others believe this to be as early as 1663 or even before. This notion is based on a reference in a publication of the Danzig based merchant-botanist Jacob Breyne (1637-1697). W.C.H. Machen, Warmond voorheen en thans, de voormalige ridderhofstede te Warmond, tweede deel, (s.1.: N.V. "De Leidsche Courant", 193), p. 47 "Lochorst [...] werd in 1663 door Hieronymus van Beverningk verbouwd"; see also Henk Rijken, Leidse Lustwarande Geschiedenis van de tuinkunst op kastelen en buitenplaatsen rond Leiden, 1600 - 1800, (Leiden: Primavera Pers, 2005), pp. 235-8; Mary Gunn and L.E. Codd (eds), Botanical Exploration of Southern Africa, (Cape Town: A.A. Balkema, 1981), p. 29. Schotel, Iets over Hieronymus van Beverningh en Bruno van der Dussen, p. 62 Beverningh bought the estate in 1672.

${ }^{54}$ H. Veendorp and L. Baas Becking, Hortus Academicus Lugduno Batavus, the development of the gardens of Leyden University 1587-1937, (Haarlem: Joh. Enschedé, 1938), p. 82. Regionaal Archief Leiden: Archiefnr. 512, inventarisnummer 687. Akte van verkoop van het kasteel Oud Teylingen of Lochorst, 1675. "huijse ende goederen van Oud Teijlingen [...] met de thuijnen, boomgaerden, plantagie, gragten ende cingelen daer aen ende toebehorende, [..] ende bij de nieuwe metinge van Jan Douw geswooren landtmeter inden jaere 1665 over de geheele jurisdictie van Warmondt gedaen, groot gevonden vijff morgen [...]." I did not find any pictures of Beverningh's garden. Possibly Jan Douw is the grandson of land surveyor Jan Dou who we met in chapter one.

${ }^{55}$ Nationaal Archief, Archief 1.10.27, Bestanddeel 377, copy of the testament of Beverningh. "En ik voort mijn begeeren dat op de bibliotheecq van de universiteijt tot Leyden sal worden gebracht, mijn hortus Eijstenttensis, geillumineerd, in erkentenis van de eene die ik hebben gehad, van soo veel jaeren en bekleiden het curatorschap van dezelven."

${ }^{56}$ Gunn and Codd, Botanical Exploration, p. 184. Natural History Museum London, HS 75, Cape plants collected by Hermann. Veendorp and Baas Becking, Hortus Academicus, p. 86; Molhuysen, Bronnen tot de Geschiedenis, p. 16, p. 59, and appendix p. 15; Wijnands, "Hortus auriaci," p. 73. Elizabeth den Hartog and Carla Teune, "Gaspar Fagel (1633-88): His garden and plant collection at Leeuwenhorst," Garden History, Journal of the Garden History Society, 30 (2002), pp. 191-205, p. 195.

${ }^{57}$ Heniger, Hendrik Adriaan van Reede tot Drakenstein, p. 164 and p. 171; Gunn and Codd, Botanical Exploration, p. 30.

${ }^{58}$ Roob and Hoff, Jacob und Johann Philipp Breyne, p. 79.

${ }^{59}$ Nationaal Archief, Archief 1.10.27, bestanddeel 377, copy of Van Beverningh's testament. "De boeken met gedroogden plantten, leggende in mijnen bibliotheecq, ook de afgeteekende planten en bloemen gelegen in een seer groot parcquement aldaar." 
HOLLAND'S HORTUS AND BALTIC BOTANY: TRANSFORMING AND TRANSPORTING 'MOTHER NATURE' ALONG THE 'MOTHER OF ALL TRADES' ROUTE.

${ }^{60}$ In 1741 this manuscript with University Library of Leiden watermark was possibly written by the librarian Gronovius after the purchase of the Beverningh collection.

${ }^{61}$ Steven Shapin, "The House of Experiment in Seventeenth-Century England," Isis, 79 (1988), pp. 373-404, see particularly about disinterested gentlemen pursuing natural inquiry in their private quarters, p. 397.

${ }^{62}$ This manuscript is kept in the Nationaal Herbarium in Leiden. Some of the herbaria have gone lost over time. It listed amongst others: Herbarius vivus Promont. Bonae Spei, coll. et dig. a [vel] Paulo Hermanno. Tom I et unicum, pagg. 49, uarum singulae plantas ensicatas [sistunt]; Herbarius vivus Zeilonensis al [...] coll. et dig. tom I pagg. 75; Herbarius vivus, ab [...] Italo, ut videtus, compositus a 1664 quem H. Beverningio done dedit D. van Meeuwen a 1676 pagg. 103; Collecteo plantarum marinareum pagg. 16 quarum pleracque quator plantas exhibent; Plantae rariones a D. Boccone in Sicilia, Melita cet. Coll. quarum historia edita Londini a 1674 pagg.; Folia sex plantarum e Java a doct. Cleyer a 1676 transmissa.

${ }^{63}$ Now in the Nationaal Herbarium Leiden.

${ }^{64}$ Veendorp and Baas Becking, Hortus Academicus, pp 88-90, the evergreen Marsh Elder Iva fruticans L., and the ordinary nasturtium Tropaeolum majus L.

${ }^{65}$ Leonard Plukenet's manuscript Speculum Herbarum is now at the British Museum of Natural History, Sloane Herbarium 91; Dandy, The Sloane Herbarium, pp. 157-158, Dandy misspells Beverningh to Reverginiano. Den Hartog and Teune, "Gaspar Fagel," pp. 191-205. ${ }^{66}$ See for Poulle: Marisca Sikkens-de Zwaan, "Magdalena Poulle (1632-99): a Dutch lady in a circle of botanical collectors," Garden History, Journal of the Garden History Society, 30 (2002), pp. 202-220; P.H.J. van der Laan, "The Poulle brothers of Amsterdam and the North Sea and Baltic trade, 1590-1620," in: Heeres, Hesp, Noordegraaf and Van der Voort, From Dunkirk to Danzig, pp. 317-330. Both Bentinck and de Flines featured in chapter two of this dissertation.

${ }^{67}$ British Library, S1.MS. 2729, fol. 89. In a letter from Ten Rhyne to Sibelius 30 November 1681, he mentioned his wife's uncle, the minister Quirinus Bosch of Warmond.

${ }^{68}$ Paolo and Silvio Boccone, Museu di Plante rare delle Sicilia, Malta, Corsica, Italia, Piemonte, e Germania, (Venice: Joh. Baptista Zuccato, 1697), pp. 185-6: "Notitie partecipate al Padre Silvio Boccone dal Dottissimo Botanico Jacob Brayne intorno la Facultà, e Virtù di questa Radice, Descriptio Virium Radicis Ninzi, Gis Sem."

${ }^{69}$ Roob and Hoff, Jacob und Johann Philipp Breyne, p. 43.

${ }^{70}$ Wijnands, "Hortus auriaci," see p. 67. Or Ten Rhijne sent these objects to Breyne, who then gave it to Beverningh, see for this argument: Cook, Matters of Exchange, p. 321. Ten Rhijne's Latin text Exerpta ex observationibus [...] De frutice Thee is in Breyne's archive, Chart. A 788 Bl. 191-194, see: Roob and Hoff, Jacob und Johann Philipp Breyne, p. 39. Breyne, Centuria, p. 115, the drawing was sent to Beverningh.

${ }^{71}$ See Breyne, Centuria, appendix: "De frutice thee [...] Jacobum Breynium transmissarum."

${ }^{72}$ Breyne, Centuria, p. 115.

${ }^{73}$ Jan van der Groen, Den Nederlandtsen hovenier, (Amsterdam: Marcus Doornick, 1670), the last part of this volume is by Peter Nylandt, "De Verstandige Hovenier, over de twaelf maenden van 't Jaer." 
HOLLAND'S HORTUS AND BALTIC BOTANY: TRANSFORMING AND TRANSPORTING 'MOTHER NATURE' ALONG THE 'MOTHER OF ALL TRADES' ROUTE.

${ }^{74}$ Christoph Schweikardt, "More than just a Propagandist for Tea: Religious Argument and Advice on a Healthy Life in the Work of the Dutch Physician Cornelis Bontekoe (16471685)," Medical History, 47 (2003), pp 357-368.

${ }^{75}$ Cook, Matters of Exchange, p. 293.

${ }^{76}$ Kuijlen, "De Danziger Botanicus en Koopman Jacob Breyne," pp. 116-118. Since these men were, according to historian Jos Kuijlen, childhood friends

${ }^{77}$ Breyne, Centuria, see caps. XLIIX [sic], LX, LXI, LXII, LXXXIV, XCIII, XCIV, XCV.

${ }^{78}$ Breyne, Centuria, see pp. 131 and 135.

${ }^{79}$ Cooper, Inventing the Indigenous.

${ }^{80}$ Jacob Breyne, Prodromus Fasciculi Rariorum Plantarum, (Danzig: David Fridericus Rhetius, 1680). Preface: "Excellentissmi Domini, Domini Hieronymi van Beverningk, Academiae Lugduni Batavorum, Magnifici atq. Nobilissimi Domini Herberti â Beaumont, Nobilissimi q. ac Amplissimi Domini Juannis Commelyni, sicuri etiam Nobilissimi Dominorum Francisci â Sewenhuysen, Philippi de Fleunis \&c."; Gunn and Codd, Botanical Exploration, pp. 28-30. These were same names of amateur botanists as Leonard Plukenet had listed in his Speculum Herbarum compiled after George London's visit to Dutch gardens: Sloane Herbarium 91.

${ }^{81}$ Breyne, Prodromus, Breyne possibly came to Holland together with the July cereal harvest.

${ }^{82}$ George Meister, Der Orientalisch-Indianische Kunst- und Lust-Gärtner, eds. Friedemann Berger and Wilfried Bonsack, (Weimar: Gustav Kiepenheuer Verlag, 1973), p. 13, "Herr Jacobus Breynius [...] das meiste von Gesäme und andern dergeleichen Plflanzen, unter andere auch die 300 Bogen schön gemalte indianische oder japponische Herbarien von mir bekommen und dahero in seinem herrlichen Buch: 'Prodromus Fasciculi rariorum Plantarum Secundis' genannt...” and on p. 141 “...ein Schreiben an Herrn Jacob Breyno in Danzig, der ein großer Liebhaber ist von den Kräutern und allen Gewächsen, die er auf seine Kosten beschreibt und drucken läßt [...] das Schreiben selfst zu überliefern.” And page 153: "Ich aber bekam von Sr. Exell., dem Herrn Gouverneur, und ließ mir einhändigen an dem Kap 3 Kasten für seine Königliche Hoheit, den Prinzen von Oranien, 5 Kasten für Sr. Excell. Herrn Caspar Fagel, Pensionarium von Holland, item 9 Kasten eben dergleichen Baum-, Blum- und Garten-Gewächse für den Medizinischen Garten zu Amsterdam, summa 17 Stück Kasten mit Erde und allerhand Gewächsen." Which he upon arrival presented to the head-gardeners of each garden.

${ }^{83}$ Breyne, Prodromus, see for example p. 101, Turbith Officinarum \& Garziae atque Acostae. Turpetum repens, foliis Althœe, vel Indicum, Casp. Bauh. Pin. Convulvulus Indicus alatus maximus, foliis Isbisco nonnihil simillibus angulosis, Hermanni, C. Hort. Turpetum verum seu album, Cleyeri, qui nobis anno præterito semina per Georgium Meisterum ex Batavia Jacatrensi transmisit. Hoc esti in Hollandia nullo in horto vidi, semina tamen recentia variis ibi Amicis communicavi.

${ }^{84}$ Heniger, Hendrik Adriaan van Reede tot Drakenstein, see page 71. Gunn and du Plessis, The Flora Capensis, p. 16.

${ }^{85}$ Vertesi, "Instrumental images," see notably pp. 220-228.

${ }^{86}$ Stanley H. Johnston, Jr (ed.), The Cleveland herbal, botanical, and horticultural collections: a descriptive bibliography of pre-1830 works from the Libraries of the Holden Arbo- 
HOLLAND'S HORTUS AND BALTIC BOTANY: TRANSFORMING AND TRANSPORTING 'MOTHER NATURE' ALONG THE 'MOTHER OF ALL TRADES' ROUTE.

retum, the Cleveland Medical Library Association, and the Garden Center of Greater Cleveland, (Kent: Kent State University Press, 1992), p. 236. Stephen Cousius is the Latinized version of Stephan Cousijns. Jan Veenhuysen is spelled by Johnston as: Jan Weenhuysen and I. Veenhuysen.

${ }^{87}$ Inga Elmqvist Söderlund, Taking Possession Of Astronomy; Frontispieces And Illustrated Title Pages In 17th-Century Books On Astronomy, (Stockholm: The Center for History of Science at the Royal Swedish Academy of Sciences, 2010). Lambertus Visscher (1633-after 1690) was commissioned to engrave the frontispiece of Firmamentum Sobiescianum, sive Uranographia, (Danzig, 1690), and the Cometographia, (Danzig, 1668), after designs of Stech, p. 97. According to the Nieuw Nederlandsch Biografisch Woordenboek Visscher was in Amsterdam in 1673 and in 1691 he was in Italy for a commission; he probably died soon after 1691, see http://www.inghist.nl/retroboeken/nnbw/\#10:566.

${ }^{88}$ Söderlund, Taking Possession Of Astronomy, see pp. 95-96.

${ }^{89}$ Breyne, Centuria, cap XL 93 and cap XLI: Stephan Cousijns was commissioned by Beverningh to make these drawings, caps XLIV, XLV, and XLVI were painted by Cousijns, then drawn by Stech and etched by Saal.

${ }^{90}$ Wijnands, Zevenhuizen and Heniger, Een Sieraad voor de Stad, pp. 70-74 on the use of paintings and watercolours and the construction of an herbal.

${ }^{91}$ On the role of physicians as inquirers and dispersers of natural history, see: Harold J. Cook, "Physicians and natural history," N. Jardine, J.A. Secord and E.C. Spary (eds), Cultures of Natural History, (Cambridge: Cambridge University Press, 2000), pp. 91-105. On the constitution of natural history through exchange and commerce of "matters of fact": Cook, Matters of Exchange.

92 Margocsy, "“Refer to folio and number'," pp. 63-89.

${ }^{93}$ Bruno Latour, "Visualization and cognition: Thinking with the eyes and hands," Knowledge and Society: studies in the sociology of culture past and present, 6 (1986), pp. 1-40, notably p. 13.

${ }^{94}$ Johan de Jong, "Drawings And Spices: Accumulation And Ships Of The Dutch East India Company," Lissa Roberts (ed), Centres and cycles of accumulation: Material and Knowledge production and exchange in and around the Netherlands during the early modern period (forthcoming).

${ }^{95}$ Heniger, Hendrik Adriaan van Reede tot Drakenstein, p. 130 for more on the transformation of a drawing into an etching. See also: D.O. Wijnands, The Botany of the Commelins, (Rotterdam: A.A. Balkema, 1983).

${ }^{96}$ I have to thank Erik Jorink for this suggestion. This manuscript is in the Koninklijke Bibliotheek The Hague.

${ }^{97}$ Stephaan Blankaert, Den Nederlandschen Herbarius, (Alphen aan den Rijn/Brussels: Stafleu's Wetenschappelijke Uitgeversmaatschappij b.v.,1980). In his introduction he writes that he had made all the drawings. He does not give the name of the engraver.

${ }^{98}$ See the master thesis of Ruben E. Verwaal, Hippocrates Meets the Yellow Emperor; On the Reception of Chinese and Japanese Medicine in Early Modern Europe, 1650-1750, (Utrecht: Utrecht University, 2009, electronically available) p. 42 on the shipping of papers between these men.

${ }^{99}$ Heniger, Hendrik Adriaan van Reede tot Drakenstein, see also p. 130 on the etching process. 
HOLLAND'S HORTUS AND BALTIC BOTANY: TRANSFORMING AND TRANSPORTING 'MOTHER

NATURE' ALONG THE 'MOTHER OF ALL TRADES' ROUTE.

${ }^{100}$ For more on the hybrid act of hands and minds, see chapter two of this dissertation.

${ }^{101}$ Margocsy, "'Refer to folio and number'," pp. 63-89.

${ }^{102}$ Ogilvie, The Science of Describing, pp. 177-181.

${ }^{103}$ Munting, Nauwkeurige beschryving der aardgewassen, “...genieten de verlustiging haars gemoeds in " $t$ betrachten van de zeldzaamheeden der Natuur ontrent allerley gewassen; en de printverbeeldingen zullen hunne oogen verstrekken voor een hof in haar huys."

${ }^{104}$ Munting, Waare Oeffening der Planten, p. 33, "leere God ende de Natuire kennen, het welke zonder ons zelfs kennisse onmoogelijk is; Waar toe nochtans indien wy komen konnen, zullen van hem een meerder Licht verkrijgen, ende de Natuire in haar verborgen kracht begrijpen moogen."

${ }^{105}$ Regionaal Archief Leiden. Archiefnummer 512, Inventaris van het huisarchief van de heeren van Warmond, 1347-1900 (1911), inventarisnummer 164. Van Beverningh left no childeren.

${ }^{106}$ Rijken, Leidse Lustwarande, p. 235. Oud-Teylingen was demolished in 1824. 


\section{Conclusion}

\section{Seventeenth-century Dutch gardens and the Dutch Republic}

In addition to what they have to tell us about the situated history of natural inquiry and invention, the four case studies discussed here can also be said to represent the physical, cultural, commercial, and social landscape of the Low Countries in the seventeenth century. This dissertation gives insight into the world of Dutch 'gardeners', the men and women who variously were engaged with cultivation, botany, and agriculture. We have seen how in a variety of Dutch gardens, actors and objects applied and helped to stimulate further natural inquiry and invention, while they sought to shape and explain nature mathematically, practically and aesthetically. But focussing on gardening in the Golden Age of the Dutch Republic also points the way to understanding the broader interactions between and impact on Dutch culture, commercial networks, social relationships, and connections between the local and the global.

As illustrated by the full range of gardens discussed here, the Dutch landscape in the seventeenth century revolved at least partially around trade, the accumulation of goods, prices, knowledge, and storage. As historian Woodruff Smith argues, trade depended on the construction of inventories, a central administration, as well as regular updates sent by correspondents from nodes along Dutch trading routes. Merchants recorded all incoming information and goods before stabilizing, storing, and dispersing these for future use and advantage. ${ }^{1}$ From the Baltic region, Batavia, Japan, and South Africa came a steady stream of natural specimens, commodities, and knowledge. In order to further this commercial enterprise, the accumulated knowledge and goods were reworked, dispersed, transplanted, or sold to other interested parties. This growing 'marketplace' attracted various people who tried to make a living either in the Netherlands or somewhere along its trading routes. ${ }^{2}$ Foreign fortune-seekers brought with them their knowledge and skill that they could use and adapt to the new circumstances. The Netherlands, in other words, were an entrepôt for matters, facts, and people.

The Dutch Republic had a relatively flexible social order where commerce greatly shaped society and landscapes. The importance of commerce is noticeable in Dutch gardening as it motivated and financed the Beemster drainage and the cultivation of the Cape of Good Hope, and allowed for the transplantation of exotic nature and knowledge. A large group of rich merchants, administrators, and nobles were in the 
position to expand their gardens and plant collections with precious bulbs and books, while further stimulating the commercial cultivation of nature or pursuing an inquiry into botany and the working of nature. Seventeenth-century Dutch gardens, then, showcased the intricate connections between culture and commerce. These sites of enhanced nature formed part of a larger knowledge and trading network as they allowed for an importation and exportation of practices, knowledge, and objects. Furthermore, Dutch gardens connected people from different layers of society in order to engineer and steward nature into an orderly garden.

The chapter on the Beemster garden shows the links between commerce and oeconomy in the early years of the seventeenth century. The Dutch oeconomy of nature, as a way to express stewardship over nature for profit and pleasure, gave rise to a large-scale engineering project whereby preconceived notions of nature's design determined the layout. In order to become a success the drainage project accumulated trustworthy knowledge and demonstrable skill, while it was funded along the same lines as the VOC: by selling shares. Combined commerce, art, technology, and oeconomy created a showcase of Dutch culture: by displaying commercial success and engineering prowess that together 'tamed' nature for the benefit of its inhabitants.

The knowledge and skill that came out of the Beemster were later used and adapted for other drainage projects, in Holland, in and around Danzig, at the Cape of Good Hope and other places around the globe. The drainage project pointed the way for the development of the commercial and colonial enterprise at the Cape, regarding its social organisation, its agricultural design, and the taking control of land. The mental and manual inventions that stemmed from the Beemster were transformed to fit the circumstances locally. The drainage's commercial and engineering ingenuity became embedded in the Company Garden in the global Dutch network, while at the same time this agricultural development was unique and local. Through trade, Dutch skilled knowledge, matter, and facts could be transplanted to other areas, where they merged into existing and unfamiliar landscapes, and the products and practices that stemmed from these sites re-entered the Dutch knowledge and trading network.

The commercial motivation behind Dutch gardening is a recurrent topic in this dissertation. It allowed for the construction of agricultural enterprises, but at the same time it enabled the import of exotic flora and botanical knowledge. Commerce also affected the social layers of the highest noble ranks and the learned circles of Dutch universities. Collectors and examiners of nature relied on - and even demanded or ordered - the Dutch trading network to provide for an ongoing supply of exotic rarities. Private and university collections became entrepôts for naturalia and botany.

As the histories of individual gardeners, such as those of the noblemen Hans Willem Bentinck and Christiaan Huygens, regent Hieronymus van Beverningh and botanist-merchant Jacob Breyne convey, gardening depended on being part of a larg- 
er network of political, learned, and mercantile connections, friends, and family to enable the pursuit of understanding, collecting, and manipulating nature. The books produced by Huygens and Breyne were partly shaped by the knowing and doing of others, just as their counterparts, the gardens, formed an important repository for nature and knowledge that helped the formation of these books. At the same time, these two histories highlight that gardening overstepped regional boundaries, as it imported, processed, and re-exported its knowledge and nature from one site to a wider network of other sites. Breyne's Centuria and Huygens's Traité de la Lumière reached a large audience throughout the Western world, while in the private gardens visitors were allowed to come, enjoy, and examine these collections of natural treasures.

While the physical landscapes of Dutch gardens were geographically rooted, their stories point to the centrality of movement in the history of the Netherlands in the seventeenth century. This movement was cultural, social, and commercial. People came to Amsterdam to seek their fortune by joining the VOC or to seek refuge from religious prosecution. Merchants like Breyne moved to various parts of the mercantile realm to oversee their family's business. Danzig was one of the prominent cities to move to, as Dutch-Baltic connection had long history, involving both the Hanze trade and a shared Protestant background.

In the Republic there was movement within and between social layers of people wanting to attain a better station for themselves. This could be done by accumulating wealth, obtaining a university degree, and by taking up gardening as a pastime. This ongoing movement sent political figures, merchants, artisans, and nobles, and philosophers around Europe and the world, which in turn allowed for a movement of objects, papers, plants, practices, facts, and commodities. The ongoing movement of goods and facts was tied to a strong paper network regarding the registration of goods and prices, charts of lands, seas, and stars, and the cataloguing and describing of naturalia.

To research Dutch gardens in the seventeenth century does not begin or end at a garden gate. It opens a door to a seemingly unstoppable flow of people and objects moving in and out. Otto Mentzel, as quoted in the beginning of chapter three, described the constant movement of the Dutch mercantile network as a relentlessly acting and reacting flow of ebb and flood. Mentzel's metaphor can be used to describe the seventeenth century Dutch 'landscape' which embedded the local - a garden - and the global - commerce, natural inquiry, inventing, and agriculture. A garden, as an immovable site, formed an intersection of people, plants, and objects that continuously moved in, became transplanted or transformed, and then moved out again.

The permanent movement of knowledge and nature, of natural inquiry and invention, was shaped by and shaped Dutch gardens as symbols of culture, society, 
and commerce. This Dutch history of movement interconnected the Low Countries to the global. In the name of the VOC, the Dutch cultivated unfamiliar landscapes and used these trade routes to further control and contemplate nature. Parallel situations happened a little later in England and France, as historian Richard Drayton argues, as they likewise established overseas trading empires that brought botanical treasures to Europe. ${ }^{3}$ This gave rise to a growing European-wide exchange of bulbs, seeds, plants, books, and other natural and artificial materials, as chapters two and four advocate.

The contribution of this dissertation to the history of science and technology is to present a history that ties Dutch gardening to commerce, agriculture, and art, and to point to a constant movement of people, practices, facts, and goods, that together gave rise to natural inquiry and invention in and outside the Low Countries. It fits into the growing body of books that discuss the ties between Dutch commerce and the production and consumption of knowledge. ${ }^{4}$ Moreover, this dissertation relates to recent publications that focus on global history and the history of go-betweens as a way to further bring together the histories of science and technology. ${ }^{5}$ Bruno Latours concept of circulation of knowledge and materials has been used in this dissertation as a model to structure the hybrid histories of gardens, natural inquiry and invention. Circulation of knowledge and materials depends on the mediating, contemplating and manipulating acts of go-betweens. They helped to accumulated and transform mutable and immobile knowledge and practices into stable and mobile objects.

Latour makes a strong case for the transition from 'immobile mutables' into 'immutable mobiles' transformed into stable objects that could be transported to centres of accumulation. Knowledge, practices, and materials needed to be rendered robust in order to circulate for others to see. Various stages - or flexible layers of mobiles - preceded the finished product. This flexibility allowed gardeners to adapt knowledge, nature, and instruments to meet local requirements in gardens, or that gardening changed preconceived and published notions regarding natural inquiry, inventions, and practices. This meant that gardeners and amateurs - as mediators of knowledge and materials -changed herb books, plants, and minerals through nature examination and experimentation to fit in their gardens, libraries, and studies, while they gave a new or adapted meaning and explanation to these elements. Through the circulation of knowledge, objects, and plants, the production of knowledge and materials was further stimulated, changed, and transported. This entailed that from a garden, as a centre of accumulation or inventive intersection, was a fertile soil for the ongoing pursuit of natural knowledge and inventions. The mundane act of gardening indeed contributed to the rise of natural inquiry and invention in the Netherlands, while it simultaneously firmly rooted the work of the hand and mind in fertile soil. 
1 Woodruff D. Smith, "The Function of Commercial Centers in the Modernization of European Capitalism: Amsterdam as an Information Exchange in the Seventeenth Century," The Journal of Economic History, 44 (1984), pp. 985-1005. Jan de Vries and Ad van der Woude, Nederland 1500-1815, De eerste ronde van moderne economische groei, (Amsterdam: Balans, 2005).

2 Roelof van Gelder, Het Oost-indisch avontuur, Duitsers in dienst van de VOC, (Nijmegen: SUN, 1997).

${ }^{3}$ Richard Drayton, Nature's Government; Science Imperial Britain, and the 'Improvement' of the World, (New Delhi: Orient Longman, 2005), p. 17.

${ }^{4}$ See for example Harold J. Cook, Matters of Exchange, Commerce, Medicine, and Science in the Dutch Golden Age, (New Haven/London: Yale University Press, 2007).

${ }^{5}$ Simon Schaffer, Lissa Roberts, Kapil Raj and James Delbourgo (eds), The Brokered World, Go-Betweens and Global Intelligence, 1770-1820, (Sagamore Beach: Watson Publishing International, 2009); Lissa Roberts, "Situating Science in Global History Local Exchanges and Networks of Circulation," Itinerario, 33 (2009), pp. 1-19. 


\section{Samenvatting}

\section{Geworteld in vruchtbare velden: zeventiende-eeuwse Nederlandse tuinen en de hybride historie van materiaal- en kennisproductie.}

Hier in mach Hollandt zich dan geluckig nomen, dat zoo wel alle konsten en wetenschappen, als zeldtzame vreemdigheden, leckernyen, kostelijckheyt, ja schatten en rijckdommen, door den Goddelijcken zegen, overvloedighlijk tot haer in-vloeyen, want daer de konstenaers beloont worden, zijn zy noyt gebreck.

Jan van der Groen, Den Nederlandtsen hovenier, (Amsterdam: Marcus Doornick, 1670), inleiding.

De hovenier van de Prinsen van Oranje, Jan van der Groen, verwoordt in zijn boek Den Nederlandtsen hovenier dat, met Gods zegen, Nederland een verzamelcentrum is van kunsten, wetenschappen, natuurlijke en kunstmatige rariteiten en rijkdommen. Een land dat kunstenaars (bedoeld worden kundige mensen zoals ingenieurs, ambachtslui, tuinmannen en dergelijke) voor hun kennis en kunde waardeert, kent geen gebrek of armoede. Van der Groen propageert hier het belang van kunstenaars bij de productie van kennis en kunde. Echter, in de zeventiende eeuw trachtten rijke en adellijke geleerden en liefhebbers hun vernuftige manier van natuuronderzoek en manipulatie boven dat van ingenieurs en ambachtslui te plaatsen door te benadrukken dat zij met hun hoofd werkten en niet met hun handen. Tot ver in de twintigste eeuw hebben geschiedkundigen dit onderscheid tussen geleerden en ambachtslieden ondersteund, door technologie - waartoe ook de kunsten kunnen worden gerekend te beschouwen als toegepaste wetenschap.

Met het bestuderen van de geschiedenissen van tuinen, van de Republiek en van techno-wetenschap in de Gouden Eeuw, wil deze dissertatie aantonen dat denken en doen hand in hand gaan. Het tuinieren is een wijze van natuuronderzoek en natuurmanipulatie om het landschap te ordenen en te beheersen. Deze ogenschijnlijk alledaagse activiteit werd ondernomen door allerlei verstandige handen en vlijtige hoofden. Door deze geschiedenissen aan elkaar te koppelen, blijkt het onmogelijk vol te houden dat handwerklui moeten worden beschouwd als uitvoerders van dat 
wat geleerden hebben bedacht. Net zoals wiskundigen, filosofen en liefhebbers bezig waren de natuur te ordenen en te verklaren, waren kunstenaars, tuinmannen, ingenieurs, molenbouwers, mijnwerkers, nomaden, boeren en zeelui in staat de natuur vorm te geven en te begrijpen. Beide groepen waren op hun manier en vaak gezamenlijk bezig met het produceren van vernuftige kennis en doordachte kunde.

Het uitoefenen van wetenschap is lang beschouwd als locatieloos, neutraal en onbeïnvloedbaar door wereldse praktijken, omdat van onafhankelijke geleerden geëist werd dat hun experimenten en theorieën overal konden worden herhaald, ten overstaan van een publiek, als bewijs dat dit betrouwbare kennis was. Door het cultiveren van natuur centraal te stellen, kunnen we wetenschap niet meer als een activiteit zien die los staat van en onaangeraakt wordt door locale omstandigheden. In dit proefschrift heeft 'plaats' een belangrijke positie en het laat zien dat handelingen, zoals tuinieren, een duidelijk effect hebben op de productie van kennis en materiaal. Het omgekeerde geldt ook: de hybride geschiedenis van kennis- en materiaalproductie heeft evengoed geleid tot manipulatie en contemplatie van de natuur.

\section{De betekenis van 'tuin' in de zeventiende eeuw}

Wat was in de Gouden Eeuw de betekenis van het begrip tuin? Allereerst is een tuin een afgescheiden stuk land waarbinnen de mens, met behulp van de kunsten, de eerste, wilde natuur verbetert en verandert voor profijt en ornament. De tuin, die Cicero 'derde natuur' noemde, omvat openbare, universiteits- en privétuinen, maar ook agricultuur - of 'tweede natuur' - waar de nadruk op profijt ligt. In de zeventiende eeuw konden polders als een tuin worden beschouwd, omdat ze in cultuur gebrachte natuur zijn, afgescheiden van hun omgeving door ringdijken en kanalen. Maar men beschouwde kruidboeken of herbaria ook als pendanten van een tuin. In zo'n papieren tuin, ingeperkt door een kaft, kon de lezer immers het hele jaar de verschijningsvormen van de natuur bestuderen en bewonderen. Tot slot was een Hollandse tuin ook een metafoor voor de Republiek, als afgescheiden land gemaakt door en voor de burgers van de Lage Landen.

Net zoals een tuin meer betekenissen kent, behelst tuinieren meer dan alleen het bewerken van een tuin. Hierbij hoort ook het in kaart brengen van een terrein; het nadenken over door God geschapen natuur en hoe deze te herscheppen; het bedwingen van de natuur door het graven van sloten; het ophogen van land; het verzamelen en planten van bomen, struiken en bloemen; het aanbrengen van kunstige en kunstmatige onderdelen zoals fonteinen en tuingrotten; het verzamelen, vastleggen, drogen en bestuderen van gewassen van medicinale of exotische aard. Het alledaagse tuinieren kan leiden tot nieuwe inzichten in de werking van de natuur, alsook tot 
nieuwe vindingen om ongecultiveerde natuur na te maken in wat de mens beschouwt als Ware Natuur. De verschillende betekenissen van het begrip tuin en de daarbij horende tuinactiviteiten laten een tuin in zijn algemeenheid zien als een vruchtbare voedingsbodem die kennis en materiaal vraagt en voortbrengt. De verwevenheid tussen tuinen, natuuronderzoek en techniek/kunst leidt tot vernuftige vondsten en verklaringen om de natuur verder te kunnen beheersen en beheren.

\section{Methodologische oriëntering}

Tegelijkertijd is een tuin een interactief speelveld van mensen en objecten en maakt daardoor onderdeel uit van wat Bruno Latour heeft omschreven als "de circulatie van kennis". Deze methode houdt in dat door het circuleren van observaties, vondsten, rapporten en objecten, deze van vorm en betekenis veranderen. Dit onderzoek gebruikt Latours methodologie om te laten zien hoe het vastleggen, transporteren en herplaatsen van kennis en materialen leidt tot andere inzichten en uitvindingen op het gebied van botanie, natuuronderzoek, agricultuur en instrumenten.

Een tuin kan worden beschouwd als een laboratorium, omdat hij is afgescheiden van de omgeving, wat de gelegenheid biedt om juist hier naturalia bijeen te brengen en te onderzoeken. Het stelt mensen in staat zelf de voorwaarden te creëren om alle elementen uit de natuur te verzamelen, te herscheppen en met elkaar te vergelijken. Deze manipulatie van natuur is, als gezegd, een gezamenlijk activiteit van 'tuinlieden' die de uitkomsten herplaatsen in hun of andere tuinen; dat openbaar maken door het publiceren van boeken; door het ruilen van gewassen met andere tuinlui; door het openstellen van hun tuin voor belangstellenden. De uitkomsten - die kunnen techniek, botanie, natuurhistorie, geometrie of esthetiek omvatten - circuleerden van tuin naar tuin, zowel binnen de Republiek als daarbuiten, waarbij deze telkens werden aangepast aan de plaatselijk situatie. De in deze dissertatie besproken tuinen - die van Van Beverningh, Bentinck, de Kaap en de Beemster - vormden vernuftige velden die constant voeding konden geven aan de verdere ontwikkeling van natuuronderzoek en vondsten.

Een tuin als vruchtbaar veld maakt deel uit van de dynamica van circulatie, waarbij kennis, natuur en objecten in een constante beweging en verplaatsing verkeren. Daarbij wordt telkens gestreefd deze elementen stabiel te maken zodat ze getransporteerd en elders verder bewerkt en onderzocht kunnen worden. Stabiele objecten, zoals het landmeetkundig instrument 'de Hollandse cirkel', de tuingrot van Zorgvliet, botanische boeken, landkaarten en verhandelingen over lichtbreking zijn aan adaptatie onderhevig. Al deze representaties van kunde en kennis zijn voortvloeisels van stabiel-solide voorgangers. De Cirkel van Dou was een compilatie van andere 
instrumenten; de Grot van Ganymedes is deels opgebouwd uit materialen afkomstig van een andere tuingrot; Breyne en Huygens borduurden voort op eerdere publicaties en voegden daar hun eigen vindingen en verklaringen bij; elke nieuwe landkaart van de Kaap besloeg een steeds groter gebied. Dit levert een opeenvolging van verplaatsbare en veranderbare kennis op. Het reeds bestaande object, de voorloper, blijft als solide object bestaan, maar de kennis die het vertegenwoordigt is veranderlijk en zelfs vergankelijk.

Tuinen in de Gouden Eeuw maken dus deel uit van een complex raster van wereldwijde handelsroutes en contacten. Via dit netwerk circuleren mensen en objecten van en naar Nederlandse tuinen, maar ook tussen tuinen en tuinlieden binnen en buiten de Lage Landen. Het is zo interessant de Nederlandse tuinhistorie te koppelen aan de geschiedenis van wetenschap en technologie juist vanwege het fijnmazige web van handelsposten, scheepsroutes en VOC-personeel, ingenieurs, artsen, amateurs, kaartenmakers en handelaren. Het bedt de tuinhistorie in in het bredere kader van de sociologie en de geschiedenis van wetenschap en techniek, maar ook in de geschiedenis van Nederland, de antropologie en de kunst. Deze verbanden verstevigen de positie van de tuin als uitgangspunt van deze dissertatie: als metafoor voor de Republiek en als verzamelcentrum van kennis, kunde en materialen.

Door de bijzondere positie van de Republiek als burgerlijke handelsnatie, geleid door de Staten Generaal - waarin afgevaardigden van elk van de zeven provinciën zitting hadden - en door de VOC, ontstond een samenleving waar regenten, kooplui, de stadhouder en edellieden elk een deel van de macht bezaten. Dat leidde soms tot frictie tussen deze groepen over de vraag wie de meeste macht had: handelsrijkdom of adeldom. Zo keek de aristocratie neer op kooplieden, zoals hoofdstuk twee laat zien. De broers Constantijn en Christiaan Huygens lieten zich denigrerend uit over de rijke zijdehandelaar Philips des Flines, terwijl ze tegelijkertijd graag gebruik maakten van diens handelsnetwerk om aan IJslandse kristal te komen. In de Republiek waren de diverse sociale groepen afhankelijk van elkaar, terwijl ze zich tegelijkertijd trachtten af te zetten tegen elkaar. Maar samenwerking bleek essentieel en leidde tot het droogmaken van de Beemster en de totstandkoming van botanische boeken.

De uitwerking van deze stabiel-fragiele relatie is terug te vinden in de gecultiveerde natuur, want tuinieren is geen onafhankelijke en individuele onderneming, zoals hierboven al werd uiteengezet. In sier- en productietuinen werkten allerlei mensen samen om de Lage Landen - als ware het een tuin - te onderhouden, te besturen en te beschermen tegen de vijand: de Spanjaard en het water. Deze gevaarlijke vijand zorgde voor wanorde en diende beteugeld te worden door het aanleggen van dijken, kanalen en een degelijke omheining. Deze metafoor is uitgebeeld in de prent Allegorie op het Twaalfjarig Bestand van Willem Buytenwech (zie afbeelding 1.1). 
Er zijn dus overeenkomsten tussen tuin en Republiek in de Gouden Eeuw, wat de notie verder versterkt dat tuinieren een gezamenlijke activiteit is en alle lagen van de gemeenschap betreft om het land en de natuur te besturen.

Tuinieren behelst dus niet alleen het manipuleren, beheersen, verzamelen en bestuderen van natuur, maar ook is het een metafoor voor het besturen van de Republiek alsook van het uitgestrekte handelsnetwerk van de VOC. Via zee- en landroutes zijn mensen, brieven, objecten, planten, informatie en koopwaar verplaatst van en naar de handelsposten in Europa, Azië en Afrika en - met representanten van de Lage Landen - naar Europese landen. Hierdoor verkregen de Republiek zowel als de tuinen toegang tot een constante invoer van onbekende kennis en materialen. Dit stimuleerde niet alleen de handel, maar ook het doen van natuuronderzoek. Het leidde tot het maken van kaarten, natuurbeschrijvingen, het verzamelen van mineralen en planten, het bewaren en verschepen van naturalia en het aanleggen van tuinen in en om de handelsposten.

\section{Verweven geschiedenissen}

Tuinen, handel, natuuronderzoek, uitvindingen en de meer algemene geschiedenis van de Republiek zijn met elkaar verweven. Deze geschiedenissen kennen hun eigen geschiedschrijving, zoals die van tuin- en landschapsarchitectuur en de vaderlandse, maritieme en economische geschiedenis. Door het bestuderen van tuinen en het tuinieren komen deze vakgebieden samen tot een hybride historie van kennis- en materiaalproductie. 'Wetenschap en technologie' zijn geworteld in Hollands vruchtbare velden en maken deel uit van een groter verhaal.

Vanaf de jaren dertig van de vorige eeuw signaleerden de wetenschapshistoricus Alexandre Koyré en diens exponenten een radicale omwenteling in de geschiedenis van de wetenschap in de zeventiende eeuw: de intellectuele transformatie van het natuurwetenschappelijk denken. Dit betrof de mechanica, de astronomie en de fysica in de zeventiende eeuw, waarbij vooral de geschiedenissen van 'wetenschappers' (Galilei, Descartes, Newton) op elkaar werden gestapeld. De historicus Edgar Zilsel opende de weg voor geschiedschrijvers om de kennis en kunde van ambachtslui erbij te betrekken en hij merkte op dat het 'vroegkapitalisme' een bijdrage leverde aan de opkomst van de moderne wetenschap. In het vakgebied van de wetenschaps- en technologiegeschiedenis zijn, in de afgelopen dertig jaar, sociaal-culturele opvattingen ingebed geraakt. $\mathrm{Nu}$ ligt de nadruk bij de notie dat cultuur, wetenschap en technologie op elkaar inwerken, waarbij het boek Leviathan and the air-pump van Steven Shapin en Simon Schaffer een belangrijk keerpunt bleek te zijn. Zij en hun navolgers verbinden sociologie met de geschiedenis van de wetenschap. 
Schaffer en Shapin richten zich voornamelijk op Britse voorbeelden om de socioculturele geschiedenis van wetenschap en technologie te vertellen. Maar er is een groeiende aandacht voor andere gebieden waar natuurhistorisch onderzoek en vindingen plaatsvonden. Deze these richt zich op de productie van kennis en materialen in de Republiek en twee gebieden in de periferie die door de handel verbonden zijn met Holland: Kaap de Goede Hoop en Dantzig. Deze locaties dragen bij aan de circulatie en productie van kennis en materialen, niet alleen van deze gebieden naar het vaderland, maar ook omgekeerd, zoals de hoofdstukken drie en vier laten zien.

In de tuingeschiedenis is veelal aandacht besteed aan de esthetische kwaliteiten van tuinen, waarbij de verwevenheid tussen geometrische vormgeving, Godsbeeld, Grieks-Romeinse gedachtegoed, tuinsculpturen, sociale status en botanie worden behandeld. Historici presenteren tuinen als toevluchtsoorden om het ongezonde (stads) leven te ontvluchten en als verzamelplekken van artificiële en natuurlijke rariteiten. Erik de Jong heeft in zijn boek Natuur en Kunst, Nederlandse tuin- en landschapsarchitectuur 1650-1740 deze verwevenheid op heldere wijze belicht, waarbij hij de relatie tussen kunst en natuur onderzoekt en ook aandacht besteedt aan de rol van technologie en natuurwetenschap in Hollandse tuinen. Echter, mijn dissertatie argumenteert juist dat tuinen niet alleen een entrepot zijn van natuurhistorisch onderzoek en uitvindingen, maar dat de laatste twee mede door het tuinieren een vorm krijgen. Door het contempleren en manipuleren van natuur door tuinlieden en liefhebbers kan natuuronderzoek en manipulatie een voedingsbodem vinden en maakt daardoor deel uit van de hybride geschiedenis van Hollandse tuinen. Deze activiteiten geven vorm aan een tuin, terwijl een tuin tegelijkertijd vorm geeft aan deze activiteiten.

Dit amalgaam van geschiedenissen komt in deze dissertatie in vier onderzoeken naar voren. Drie van de vier hoofdstukken zijn als artikelen verschenen in tijdschriften en bundels. Het vierde hoofdstuk ligt ter beoordeling bij een wetenschappelijk tijdschrift. Ze zijn hier met kleine wijzigingen opgenomen. Alle hoofdstukken illustreren op verschillende wijzen hoe tuinen een voedingsbodem vormden voor de hybride historie van materiaal en kennisproductie in Nederland in de Gouden Eeuw.

\section{Hoofdstuk 1}

\section{De Beemsterpolder: een behoudende uitvinding én Hollands grote lusthof.}

De Beemster, aangelegd in de jaren 1608-1612, is een voorbeeld van hoe tijdens de werkzaamheden materialen en kennis werden geproduceerd. De inpoldering van de Beemsterpolder leidde tot twee belangrijke uitvindingen: een molenontwerp en een landmeetkundig instrument. Deze vernuftige vondsten waren zogenaamde behoudende of conservatieve uitvingen: ze borduurden voort op een bestaand ontwerp 
dat aangepast werd om tegemoet te komen aan de plaatselijke omstandigheden. In verschillende stadia van het droogmalen maakten landmeters telkens nieuwe kaarten om de inpoldering te beheersen en de nieuwe natuur te onderwerpen aan het Goddelijke Ideaal: een harmonisch en geometrisch ingerichte lusthof. Dit project bestond uit een samenwerking tussen ingenieurs, kooplui, molenbouwers, landmeters, regenten en professoren. Toen de Beemster voltooid was, prees de dichter Joost van den Vondel in een lofdicht hoe de mens met Gods Zegen de harmonie tussen de vier elementen - aarde, water, lucht en vuur - had hersteld en herschapen in een vruchtbaar veld.

\section{Hoofdstuk 2}

In het licht: kristallen en de herschepping van natuur in zeventiende-eeuwse tuingrotten en kabinetten.

De constructie van de Grot van Ganymedes van Hans Willem Bentinck op zijn landgoed Zorgvliet en de Verhandeling over Licht van Christiaan Huygens speelden zich beide af in de periode 1670-'90. Centraal staat de carrière van Duits bergkristal vanaf het moment dat deze gehaald zijn uit de 'buik van de aarde' en in het licht zijn gebracht. In de handen van anonieme mijnwerkers, grotbouwers, diverse edellieden als Bentinck en Constantijn Huygens en de wiskundige Christiaan Huygens werden de kristallen onderzocht, bewerkt en verklaard. Diverse verstandige handen en vlijtige hoofden waren bezig om hun licht te laten schijnen over wat er zich binnenin de aarde afspeelde. Hun ideeën over de betekenis en werking van bergkristal verschilden; een mijnbouwer dichtte een bewerkte kristal goddelijk-magische krachten toe, terwijl de grotbouwers probeerden de natuur ter herscheppen in een kunstmatige tuingrot door bergkristal samen met andere elementen uit de aarde te combineren zoals water en aardenwerken salamanders. Door middel van geometrisch opgestelde spiegels en bovenlichten ontstond er een spannend spel van licht, reflectie en refractie, waardoor op esthetische wijze de werking van licht werd nagebootst. Tegelijkertijd bewerkte Christiaan Huygens in Parijs allerlei soorten kristallen, waaronder IJslandse kristallen en stukken bergkristal - dezelfde als gebruikt in de Grot van Ganymedes - om lichtbreking te onderzoeken, experimenten die hem hielpen het fenomeen licht te beschrijven en te verklaren. Maar Huygens, schreef hij zelf, bleef in gebreke bij de verklaring hoe een kristal groeide en zijn regelmatige vorm kreeg in de donkerte van de aarde. Deze vraag is - in ieder geval op esthetische wijze opgelost door de grotbouwers van Bentinck. In de handen en hoofden van deze heterogene groep konden licht, reflectie en refractie worden gemanipuleerd en verklaard. 


\section{Hoofdstuk 3 \\ De Compagnies tuin en de verandering en verhandeling van natuur en kennis op Kaap de Goede Hoop (1652-1700).}

De VOC-tuin op Kaap de Goede Hoop neemt een centrale plaats in in dit hoofdstuk, waar het functioneert als een Latouriaans 'verzamelcentrum' van de productie en circulatie van kennis en materiaal. De Compagniestuin bestond uit een verzameling van mensen en materialen, afkomstig uit de regio en uit overzeese gebiedsdelen. Al die elementen vermengden daar; ze werkten op elkaar in en werden verder getransporteerd.

Wat begon als een kleine Hollandse verversingspost in 1652, leidde al snel tot kolonisering van het vruchtbaarste land, dat men als 'onbewoond' beschouwde. Het succes van deze tuin lijkt erop te wijzen dat de Hollanders de Kaapse nomaden, de Khoikhoi, de Westerse (agri-)cultuur hebben bijgebracht. De nomaden en de Hollanders verruilden en verhandelden kennis en materialen met als doel er zelf beter van te worden. Deze handelingen geschiedden met behulp van een tussenpersoon op wat historicus Richard White een 'middenveld' noemde. Op een middenveld hielp de tolk/tussenpersoon de voorwaarden te scheppen, zodat vertrouwen ontstond en er handel en uitwisseling mogelijk was. De verkregen kennis - vastgelegd op papier of mondeling doorgegeven - en goederen circuleerden naar de verder weggelegen nomaden en Hollanders. Zij konden zo kennismaken met de 'ander'. Door deze circulatie werd de kennis over de ander steeds verder uitgebreid. De wijze van circulatie bij de Khoikhoi was zwakker, doordat zij geen schrift kenden noch bezit verzamelden. Uiteindelijk zijn de Khoikhoi bezweken onder de koloniale expansie. Ze legden het af tegen de macht van het papier en de ploeg. Wat rest in de geschiedenis van de overwinnaars.

\section{Hoofdstuk 4}

Hollandse hortus en Baltische botanie: transformeren en transporteren van 'moeder natuur' langs de route van de 'moedernegotie'.

De productie van botanische kennis speelde zich af in de Republiek: in de universiteitstuin van Leiden, in de privétuin van Hieronymus van Beverningh en ook in en om Dantzig, alwaar de Nederlandse koopman-liefhebber Jacob Breyne zich toelegde op het verzamelen van inheemse planten en van exotische exemplaren, direct verkregen uit Azië of via zijn Hollandse contacten. De route die deze botanische kennis en materialen aflegde, volgde de moedernegotie, de graanhandel, die de gebieden aan de Oostzee, en dan met name Dantzig, verbond met de Lage Landen. Deze langja- 
rige, intensieve en winstgevende handel bracht kooplui, kunstenaars en ingenieurs - en hun kennis en materialen - van en naar Dantzig. Botanici, artsen, tuinmannen en tuinliefhebbers transformeerden planten in vaste, tijdgebonden tuinen, zoals de tuin van Van Beverningh. Tegelijkertijd veranderden zij planten in transporteerbare en permanente papieren tuinen als kruidboeken en herbaria. Om kennis en materialen solide te maken, transformeerden onderzoekers en bewerkers van natuur bestaande planten tot tekeningen en etsen. Daarbij refereerden zij regelmatig aan eerder gepubliceerde botanische kennis, die vervolgens door hen kon worden veranderd. De wisselwerking tussen deze twee soorten tuinen verbond daardoor het plaatselijke met het wereldwijde en het laat de incorporatie toe van Dantzig als handelsstad en verzamelplaats voor kennis en materialen.

\section{Tot slot}

De besproken vier hoofdstukken representeren samen de uiteenlopende verschijningsvormen van een tuin in de Gouden Eeuw. In (privé- of openbare) tuinen, polders, Kaapse velden en kruidboeken kunnen mensen zich verpozen, de natuur verzamelen en bestuderen en tot zich nemen als heilzaam middel voor lichaam en oog. Maar ook kunnen tuinliefhebbers kunstmatige manipulatie van elementen uit de natuur waarnemen, zoals flora, water en mineralen. Gezamenlijk zijn deze onderdelen afspiegelingen van de vruchtbare en vernuftige velden waarin kennis en materiaalproductie en -consumptie geworteld zit en eruit voortvloeit om elders - in andere tuinen of in boeken - weer te worden aan- en ingepast. De voorbeelden geven de diverse facetten van tuinen en het tuinieren weer. Het ondersteunt het idee dat tuinlieden afkomstig zijn uit alle lagen van de samenleving en dat zij tezamen de natuur beschouwen en beheersen, elk vanuit zijn of haar kennis en kunde.

Gepaard aan Bruno Latours concepten 'mobiel en stabiel' en 'veranderlijk en onveranderlijk' zit een mate van flexibiliteit. Deze flexibiliteit is nodig om te kunnen tuinieren en kennis, natuur en instrumenten aan te passen aan de lokale omstandigheden. Eerder gepubliceerde kennis en objecten kunnen door natuuronderzoek en plaatselijke toepassing veranderen van vorm en betekenis. De circulatie van kennis en materialen leidt tot een verdere stimulering van de productie van materiaal en kennis. Dat houdt in dat een tuin, als verzamelcentrum en vernuftig veld, een voedingsbodem is voor de voortgaande vermeerdering van kennis en kunde over natuur. In verstandige handen en vlijtige hoofden zal Latours concept van stabiele kennis en kunde blijvend onderhevig zijn aan verandering. 


\section{Bibliography}

\section{Archives:}

Bibliotheca Nazionale, Florence:

Hortus Regius Honselaerdicensis, MS. Pal. 6.B.B.5 (G.F. 182) manuscript

British Library, London:

Sloane Manuscripts:

Sl. MS. 4066, f. 271

S1. MS. 4066, f. 271 ,

S1. MS. 2729, fol. 89

British Museum of Natural History, London:

Sloane Herbarium:

HS. 75, Cape plants collected by Paulus Hermann, herbarium

HS. 91, Leonard Plukenet Speculum Herbarum

Koninklijke Bibliotheek, The Hague:

Stephaan Blankaert, Herbarium or Kruydboek 5 vols, manuscript

Koninklijk Huisarchief (Royal Archives), The Hague:

Archive of Johan Maurits van Nassau-Siegen

Leiden University Library, Leiden:

Christiaan Huygens, Traité de la Lumière, Hug 31 VII 253-312, manuscript

Archief van curatoren der Leidsche Universiteit ( -1815) AC 1 6-7. 6, fol. 18

Nationaal Herbarium, Leiden:

Apparatus Botanicus, qui olim studiis inseaviit visi D. Hieron. Van Beverning, XVII Voll. coll., manuscript

Jacob Breyne, Plantae rariones Borussia et Cassubia (S. Pomeranicae), 1673, 4 vols, herbarium

Jacob Breyne, Herbarius vivus, 2 vols, herbarium

Willem ten Rhyne, Beschrijvinge op wat wijs en manier den Theeboom geraijt en de Thee gemaakt wordt, manuscript 
BIBLIOGRAPHY

Willem ten Rhyne, Differentia Camphorae, manuscript

Nationaal Archief, The Hague:

VOC archives, used for cross-reference.

Archief 1.10.27, Bestanddeel 377, a handwritten copy of the testament of Hieronymus van Beverningh

Regionaal Archief, Leiden:

Archiefnummer 512, inventarisnummer 687 and inventarisnummer 164.

Inventaris van het huisarchief van de heeren van Warmond, 1347-1900 (1911).

DTB Nederlands Hervormd Ondertrouw (1575-1795), folio Q - 138v

Waterlandsarchief, Purmerend:

Archive Beemster Polder, Resolutions, book 3, manuscript

\section{Websites:}

Allgemeine deutsche Biographie \& Neue deutsche Biographie (Digitale Register): http://daten.digitale-sammlungen.de/0001/bsb00016320/images/index.html? fip=193.174.98.30\&id= 00016320 \&seite $=762$

Nieuw Nederlandsch Biografisch Woordenboek: http://www.inghist.nl/retroboeken/ nnbw/\#page $=566 \&$ source $=10$

Woordenboek der Nederlandsche Taal, http://gtb.inl.nl/?owner=WNT

Websites used in chapter two:

On the Ibbenbüren coalmine: http://de.wikipedia.org/wiki/Bergwerk_Ibbenbüren

On rock crystal: http://gea-drenthe.nl/nsaksen.html\#ibbenburen

On Ibbenbüren rock crystal: http://www.boerseos.de/ibbenb.php

Websites used in chapter three:

On Cape plants: http://www.plantzafrica.com/planthij/hermannia.htm

On maps of the Cape of Good Hope: http://www.atlasofmutualheritage.nl

On Cape Town Archives Repository Resolutions of the Council of Policy of Cape of Good Hope: South Africa, http://databases.tanap.net/

\section{Bibliography:}

Anon. By den dijckgraeff ende hooghe heemraden van de selve Beemster te diversche tijden ghemaeckt/by den hooft ingelanden des selfs in hare generale vergaderingen gheresumeert/ ghearresteert en ter ghewoonlijcke plaetsen ghedaen afficheren ende publiceren. (Amsterdam: Ewout Cornelisz. Muller, 1616)

Anon. Extract uit het octroy van de Beemster met de cavel-conditien, en de Kaerte van dien. Als mede 't Register van de participanten. (Purmerend: Pieter Baars, 1696) 
BIBLIOGR APHY

Andreas, Ch. Henriëtte, In en om een botanische tuin: Hortus Groninganus 1626-1966, (Groningen: Erven B. van der Kamp, 1976)

Arber, Agnes, Herbals their Origin and Evolution, a Chapter in the History of Botany 14701670, (Darien: Hafner Publishing Co, 1970)

Bacon, Francis, The Essayes or Counsels, Civill and Morall, (Oxford: Clarendon Press, 1985)

Bank, Andrew, "The Great Debate and the Origins of South African Historiography," The Journal of African History, 38 (1997), pp. 261-281

Bergvelt, Ellinoor and Renée Kistemaker (eds), De wereld binnen handbereik. Nederlandse kunst- en rariteitenverzamelingen, 1585-1735, (Zwolle/Amsterdam: Waanders, 1992)

Berkel, Klaas van, "De wetenschappelijke revolutie: een nieuwe kans voor een versleten metafoor?," Tijdschrift voor Geschiedenis, 108 (1995), pp. 483-498

Berkel, Klaas van, "Een onwillige mecenas? De rol van de VOC bij het natuurwetenschappelijk onderzoek in de zeventiende eeuw," J. Bethelem and A.C. Meijer (eds), VOC en Cultuur, (Amsterdam: Schiphouwer en Brinkman, 1993), pp. 39-58

Berkenvelder, F.C., "Some unknown Dutch archivalia in the Gdansk (Danzig) archives," W.G. Heeres, L.M.J.B. Hesp, L. Noordegraaf and R.C.W. van der Voort (eds), From Dunkirk to Danzig, Shipping and trade in the North Sea and the Baltic, 1350-1850, (Hilversum: Verloren Publishers, 1988), pp. 145-166

Bezemer-Sellers, Vanessa,"The Bentinck garden at Sorgvliet," John Dixon Hunt (ed), The Dutch Garden in the Seventeenth Century, (Washington D.C.: Dumbarton Oaks, 1990), pp. 99-129

Bezemer-Sellers, Vanessa, Courtly Gardens in Holland 1600-1650; The House of Orange and the Hortus Batavus, (Amsterdam/Woodbridge: Architectura et Natura, 2001)

Biagioli, Mario, Galileo's Instruments of Credit: Telescopes, Images, Secrecy, (Chicago: University of Chicago Press, 2006)

Biewenga, Arend W., De Kaap de Goede Hoop, Een Nederlandse vestigingskolonie, 16801730, (Amsterdam: Vrije Universiteit 1999)

Blankaert, Stephaan, Den Nederlandschen Herbarius, (Alphen aan den Rijn/Brussels: Stafleu's Wetenschappelijke Uitgeversmaatschappij, 1980)

Blok, G.A.C., "De architect Maurits Pietersz Post en de tuin van het Mauritshuis," Jaarboek van Die Haghe, (The Hague: Mouton, 1940), pp. 60-117

Blunt, Wilfrid, Linnaeus; The Compleat Naturalist, (London: Frances Lincoln, 2004)

Boccone, Paolo and Silvio Boccone, Museu di Plante rare della Sicilia, Malta, Corsica, Italia, Piemonte, e Germania, (Venice: Joh. Baptista Zuccato, 1697)

Böeseken, A.J., Memoriën en instructiën, 1657-1699, (Cape Town: Staatsdrukker, 1966)

Bogucka, M., "Dutch Merchants' Activities in Gdansk in the First Half of the 17th Century," J.Ph.S. Lemmink, J.S.A.M. van Koningsbrugge (eds), Baltic Affairs, Relations between the Netherlands and North-eastern Europe 1500-1800, (Nijmegen: INOS, 1990), pp. 19-32

Borger, G.J., "De Beemster - ideaal of compromis,” R.M. van Heeringen, E.H.P. Cordfunke, M.Ilsink and H. Sarfatij (eds), Geordend Landschap, 3000 jaar ruimtelijke ordening in Nederland, (Hilversum: Verloren 2004), pp. 75-102 
BIBLIOGRAPHY

Bosman, D.B. and H.B. Thom (eds), Daghregister gehouden by den oppercoopman Jan Anthonisz van Riebeeck, (Kaapstad: A.A. Balkema, 1952-1957) 3 vols

Bosman-Jelgersma, H.A., Vijf eeuwen Delftse Apothekers, (Amsterdam: Ronald Meesters, 1979)

Bouman, Ferry, Bob Baljet and Erik Zevenhuizen (eds) Kruidenier aan de Amstel, De Amsterdamse Hortus volgens Johannes Snippendaal (1646), (Amsterdam: Amsterdam University Press, 2007)

Botton, Alain de, The Art of Travel, (London: Penguin, 2002)

Bouwman, J., Bedijking, opkomst en bloei van de Beemster, (Purmerend: Schuitemaker, 1857)

Boyceau, Jacques, Traité du Jardinage selon les Raisons de la Nature et de l'Art, (Nördlingen: Verlag Dr. Alfons Uhl, 1997)

Breyne, Jacob, Exoticarum aliarumque minus cognitarum Plantarum centuria prima, (Danzig: David-Fridericus Rhetius, 1678)

Breyne, Jacob, Prodromus Fasciculi Rariorum Plantarum, (Danzig: David Fridericus Rhetius, 1680)

Breyne, Jacob, and Johann Breyne, Prodromus Fasciculi Rariorum Plantarum, Primus et Secundus, (Danzig: Thom. Joh. Schreberi, 1739)

Bylandt, F.W.C.P. van, Het diplomatisch beleid van Hieronymus van Beverningk, gedurende de jaren 1672-1678, (Den Haag: H.J. Gerretsen, 1863)

Chambers, David Wade and Richard Gillespie, "Locality in the History of Science: Colonial Science, Technoscience, and Indigenous Knowledge," Osiris, 15 (2000), pp. 221-240

Cohen, H. Floris, The scientific revolution: a historiographical inquiry, (Chicago: University of Chicago Press, 1994)

Commelin, Jan, Hortus Medicus Amstelodamensis, (Amsterdam: P. and J. Blaeu, 1697)

Comito, Terry, "Renaissance gardens and the discovery of Paradise," Journal of the History of Ideas, 32 (1971), pp. 483-506

Cook, Harold J., "Capitalism and Science in the Dutch Golden Age," unpublished paper.

Cook, Harold J., "The New Philosophy in the Low Countries," R. Porter and M. Teich (eds), The Renaissance in National Context, (Cambridge: Cambridge University Press, 1992), pp. 115-149

Cook, Harold J., "Physicians and natural history," N. Jardine, J.A. Secord and E.C. Spary (eds), Cultures of Natural History, (Cambridge: Cambridge University Press, 2000), pp. 91105

Cook, Harold J., "Global Economies and Local Knowledge in the East Indies; Jacobus Bontius Learns the Facts of Nature," Londa Schiebinger and Claudia Swan (eds), Colonial Botany, Science, Commerce, and Politics in the Early Modern World, (Philadelphia: University of Pennsylvania Press, 2005), pp. 100-118

Cook, Harold J., Matters of Exchange, Commerce, Medicine, and Science in the Dutch Golden Age, (New Haven/London: Yale University Press, 2007) 
Cooper, Alix, Inventing the Indigenous, Local Knowledge and Natural History in Early Modern Europe, (Cambridge/New York: Cambridge University Press, 2007)

Cramer, W., Geschichte der Graffschaft Lingen im 16. und 17. Jahrhundert, (Oldenburg: Stalling, 1940)

Cunningham. Andrew, "Getting the Game Right: Some plain words on the Identity and invention of Science," Studies in History and Philosophy of Science, 19 (1988), pp. 365-389

Cunningham, Andrew and Perry Williams, "De-centering the 'big picture': The Origins of Modern Science and the Modern Origins of Science," British Journal of the History of Science, 26 (1993), pp. 407-432

Cunningham, Andrew, "The Culture of Gardens," N. Jardine, J.A. Secord and E.C. Spary (eds), Cultures of natural history, (Cambridge/London: Cambridge University Press, 2000), pp 38-56

Daalder, Remmelt, Els van Eyck van Heslinga, J. Thomas Lindblad, Peter Rogaar and Peter Schonewille (eds), Goud uit Graan; Nederland en het Oostzeegebied 1600-1850, (Zwolle: Waanders Uitgevers, 1998)

Dandy, J.E., The Sloane Herbarium, an annotated list of the Horti Sicci composing it: with biographical accounts of the principal contributors, (London: British Museum, 1958)

Danner, Helga, Van water tot land, van land tot water; verwikkelingen bij de indijking van de Beemster, (Wormerveer: Kunstdrukkerij Mercurius, 1987)

Dapper, Olfert, "Kaffrarie of Lant der Kaffers," I. Schapera and E. Farrington (eds), The Early Cape Hottentots, (Westport: Negro Universities Press, 1970), pp. 1-77

Daston, Lorraine and K. Park, Wonders and the Order of Nature 1150-1750, (New York: Zone Books, 1998)

Davids, C.A., "On the diffusion of nautical knowledge from the Netherlands, 1550-1850," W.G. Heeres, L.M.J.B. Hesp, L. Noordegraaf and R.C.W. van der Voort (eds), From Dunkirk to Danzig, Shipping and trade in the North Sea and the Baltic, 1350-1850, (Hilversum: Verloren Publishers, 1988), pp. 217-236

Davids, C.A., "The transfer of Windmill Technology from the Netherlands to North-Eastern Europe from the 16th to the Early 19th Century," J.Ph.S. Lemmink and J.S.A.M. van Koningsbrugge (eds), Baltic Affairs, Relations between the Netherlands and North-eastern Europe 1500-1800, (Nijmegen: INOS, 1990), pp. 33-52

Dear, Peter, "Miracles, experiments, and the ordinary course of nature," Isis, 81 (1990), pp. 663-683

Dear, Peter, "What is the History of Science the History of? Early Modern Roots of the Ideology of Modern Science," Isis, 96 (2005), pp. 390-406

Dear, Peter, Lissa L. Roberts and Simon Schaffer (eds), The Mindful Hand; Inquiry and Invention from the Late Renaissance to Early Industrialisation, (Amsterdam: Edita, 2007)

Deursen, A.Th. van, De last van veel geluk, De geschiedenis van Nederland 1555-1702, (Amsterdam: Bert Bakker, 2004)

Dietz, B., "Mobile Objects: the Space of Shells in eighteenth-century France," British Journal of the History of Science, 39 (2006), pp. 363-382 
BIBLIOGRAPHY

Dijksterhuis, F.J., "Christiaan Huygens en de mechanica van het licht," M. Keestra and A. Löhnberg (eds), Doorbraken in de natuurkunde, (Amsterdam: Nieuwezijds, 2001), pp. 57-80

Dijksterhuis, F.J., Lenses and waves, Christiaan Huygens and the Mathematical Science of Optics in the Seventeenth Century, (Dordrecht/Boston/London: Kluwer Academic Publishers, 2004)

Dijksterhuis, F.J., "Constructive thinking: A case for dioptrics," P. Dear, L.L. Roberts and S. Schaffer (eds), The Mindful Hand; Inquiry and Invention from the Late Renaissance to Early Industrialisation, (Amsterdam: Edita, 2007), pp. 59-82

Dixon Hunt, John, Gardens and the Picturesque, Studies in the History of Landscape Architecture, (Cambridge: MIT Press, 1992)

Dixon Hunt, John, "Curiosities to adorn cabinets and gardens," O. Impey and A. MacGregor (eds), The origins of museums, the cabinet of curiosities in 16th and 17th-century Europe, (Oxford: Clarendon Press, 1985), pp. 193-203

Dou, Jan Pietersz and Johan Sems, Van het gebruyck der geometrijsche instrumenten, (Leiden: Jan Bouwensz, 1600)

Dou, Jan Pietersz and Johan Sems, Practijck des landmetens, (Leiden: Jan Bouwensz, 1600)

Dou, Jan Pietersz, Tractaet vant maken ende gebruycken eens nieu gheordonneerden mathematischen instrument, (Leiden: Jan Bouwensz, 1612)

Drayton, Richard, Nature's Government; Science, Imperial Britain, and the 'Improvement'of the World, (New Delhi: Orient Longman, 2005)

Driessen, Jozien, Tsaar Peter de Grote en zijn Amsterdamse vrienden, (Utrecht/Antwerpen: Kosmos-Z\&K Uitgevers, 1996)

Dupré, Sven, De Optica van Galileo Galilei, Interactie tussen Kunst en Wetenschap, (Brussel: Verhandelingen van de Koninklijke Vlaamse Academie van België voor Wetenschappen en Kunsten, 2001), vol. 5

Dym, Warren, "Scholars and Miners; Dowsing and the Freiberg Mining Academy," Technology and Culture, 49 (2008), pp. 833-859

Eamon, W., Science and the Secrets of Nature; Books of Secrets in Medieval and Early Modern Culture, (Princeton: Princeton University Press, 1994)

Elbourne, Elizabeth, Blood Ground; Colonialism, Missions, and the Contest for Christianity in the Cape Colony and Britain, 1799-1853, (Montreal/Kingston: McGill-Queen's University Press, 2002)

Elias, Johan E., De vroedschap van Amsterdam, 1578-1795, (Haarlem: Loosjes, 1903-1905)

Elphick, Richard, Khoikhoi and the founding of White South Africa, (Johannesburg: Ravan Press, 1985)

Epstein, S.R., "Craft Guilds, Apprenticeship, and Technological Change in Preindustrial Europe," The Journal of Economic History, 58 (1998), pp. 684-713

Findlen, Paula, Possessing Nature: Museum, Collecting, and Scientific Culture in Early Modern Italy, (Berkeley: University of California Press, 1994)

Findlen, Paula, "Jokes of Nature and Jokes of Knowledge: The Playfulness of Scientific Discourse in Early Modern Europe," Renaissance Quarterly, 43 (1990), pp. 292-331 
BIBLIOGRAPHY

Fleischer, Alette, "The garden behind the dyke: land reclamation and Dutch culture in the 17 th century," ICON, journal of the International Committee for the History of Technology, 11 (2005), pp. 16-32

Fleischer, Alette, “The Beemster Polder: Conservative Invention and Holland's great Pleasure Garden," P. Dear, S.J. Schaffer and L.L. Roberts (eds), The Mindful Hand; Inquiry and Invention from the late Renaissance to early Industrialisation, (Amsterdam: Edita, 2007), pp. 145-166

Fleischer, Alette, "Into the Light: constructors and examiners of nature and a Dutch 17th century garden grotto," History of Technology, 29 (2009), pp. 113-139

Fleischer, Alette, "(Ex)Changing Knowledge and Nature at the Cape of Good Hope, circa 1652-1700," Siegfried Huigen and Jan L. de Jong (eds), The Dutch Trading Companies as Knowledge Networks, Series: Intersections; Interdisciplinary Studies in Early Modern Culture, (Leiden: Brill Publishers, 2010) vol. 14, pp. 243-265

Fleischer, Alette, "The Company's Garden and the (Ex)Change Of Nature and Knowledge at Cape Of Good Hope (1652-1700)," Lissa Roberts (ed), Centres and cycles of accumulation: Material and Knowledge production and exchange in and around the Netherlands during the early modern period (forthcoming, 2011)

Furhing, Peter (ed), De wereld is een tuin; Hans Vredeman de Vries en de tuinkunst van de Renaissance, (Gent/Amsterdam: Ludion, 2002)

Gelder, Roelof van, Het Oost-indisch avontuur, Duitsers in dienst van de VOC, (Nijmegen: SUN, 1997)

Gelderblom, Arie Jan, Mannen en maagden in Hollands tuin; Interpretatieve studies van Nederlandse letterkunde 1575-1781, (Utrecht: Rijksuniversiteit Utrecht, 1991)

Glacken, Clarence J., Traces on the Rhodian Shore, Nature and Culture in Western Thought from Ancient Times to the End of the Eighteenth Century, (Berkeley: University of California Press, 1984)

Glaudemans, Marc, Amsterdams Arcadia, de ontdekking van het achterland, (Nijmegen: SUN, 2000)

Gonsalves de Mello, José Antonio, Nederlanders in Brazilië (1624-1654), de invloed van de Hollandse bezetting op het leven en de cultuur in Noord-Brazilië, B.N. Teensma (ed), (Zutphen: Walburg Pers, 2001)

Gombrich, E., "Review Lecture Mirror and Map: Theories of Pictorial Representation," Philosophical Transactions of the Royal Society of London, Series B, Biological Sciences, 270 (1975), pp. 11-149

Goossens, Eymert-Jan and Koen Ottenheym (eds), Tilman van Gameren (1632-1796), Een Nederlandse architect aan het hof in Polen, (Amsterdam: Stichting Koninklijk Paleis Amsterdam, 2002)

Grendel, E., De ontwikkeling van de artsenijbereidkunde in Gouda tot 1865, (Gouda: Oudheidkundige Kring "Die Goude", 1957)

Gregory, C.E., A Concise History of Mining, (New York/Oxford: Pergamon, 1980)

Grevenbroek, J.G., “An elegant and accurate account of the African race,” I. Schapera and E. 
BIBLIOGRAPHY

Farrington (eds), The Early Cape Hottentots The Early Cape Hottentots, (Westport: Negro Universities Press, 1970), pp. 161-299

Groen, Jan van der, Den Nederlandtsen hovenier, (Amsterdam: Marcus Doornick, 1670)

Gross, Alan G., Joseph E. Harmon and Michael S. Reidy, "Argument and Seventeenth-Century Science: A Rhetorical Analysis with Sociological Implications," Social Studies of Science, 30 (2000), pp. 371-396

Grove, Richard, "Indigenous Knowledge and the Significance of South-West India for Portuguese and Dutch Constructions of Tropical Nature," Modern Asian Studies, 30 (1996), pp. 121-143

Guelke, Leonard, "The Anatomy of a Colonial Settler Population: Cape Colony 1657-1750," The International Journal of African Historical Studies, 21 (1988), pp. 453-473

Guelke, Leonard and Robert Shell, "Landscape of Conquest: Frontier Water Alienation and Khoikhoi Strategies of Survival, 1652-1780," Journal of Southern African Studies, 18 (1992), pp. 803-824

Gunn, Mary and Enid du Plessis, The Flora Capensis of Jakob and Johann and Philipp Breyne, (Johannesburg: The Brendhurst Press, 1978)

Gunn, Mary and L.E. Codd (eds), Botanical Exploration of Southern Africa, (Cape Town: A.A. Balkema, 1981)

Hall, M., "The Archaeology of Colonial Settlement in Southern Africa," Annual Review of Anthropology, 22 (1993), pp. 177-200

Harley, J.B., The New Nature of Maps, Essays in the History of Cartography, Paul Laxton (ed), (Baltimore/London: The Johns Hopkins University Press, 2001)

Harris, S.J., "Long-Distance Corporations, Big Sciences, and the Geography of Knowledge," Configurations, 6 (1998), pp. 269-304

Hartog, Elizabeth den and Carla Teune, "Gaspar Fagel (1633-88): His garden and plant collection at Leeuwenhorst," Garden History; Journal of the Garden History Society, 30 (2002), pp. 191-205

Heesen, Anke te, "Accounting for the Natural World, Double-Entry Bookkeeping in the Field," Londa Schiebinger and Claudia Swan (eds), Colonial Botany, Science, Commerce, and Politics in the Early Modern World, (Philadelphia: University of Pennsylvania Press, 2005), pp. 237-251

Hermann, Paulus, Horti academici Lugduno-Batavi catalogus, (Leiden: Cornelium Boutesteyn, 1687)

Heilfurth, G., Der Bergbau und seine Kultur, Eine Welt zwischen Dunkel und Licht, (Zürich: Atlantis, 1981)

Heniger, Johannes, Hendrik Adriaan van Reede tot Drakenstein (1636-1691) and Hortus Malabaricus; a contribution to the history of Dutch colonial botany, (Rotterdam/Boston: A.A. Balkema, 1986)

Heuvel, Charles van den, 'De Huysbou' a reconstruction of an unfinished treatise on architecture, town planning and civil engineering by Simon Stevin, (Amsterdam: Edita, 2005) 
BIBLIOGR APHY

Hoogewerff, G.J., De twee reizen van Cosimo de Medici, prins van Toscane, door de Nederlanden 1667-1669, (Amsterdam: Johannes Muller, 1919)

Hughes, Thomas P., "The Evolution of Large Technological Systems," Wiebe E. Bijker, Thomas P. Hughes and Trevor J. Pinch (eds), The social construction of technological systems: new directions in the sociology and history of technology, (Cambridge: MIT Press, 1987), pp. 51-82

Hughes, Thomas P., American Genesis; a Century of invention and technological enthusiasm, 1870-1970 (Chicago/London: The University of Chicago Press, 2004)

Huigen, Siegfried, De weg naar Monomotapa, (Amsterdam: Amsterdam University Press, 1996)

Huygens, Christiaan, Traité de la Lumière, (Leiden : Pieter van der Aa, 1690)

Huygens, Christiaan, Oeuvres complètes de Christiaan Huygens, (Den Haag: Martinus Nijhoff, 1888-1950), 22 vols

Israel, Jonathan, The Dutch Republic, Its Rise, Greatness, and Fall 1477-1806, (Oxford: Clarendon Press, 1995)

Jacob, Margaret C., The cultural meaning of the scientific revolution, (New York: Alfred A. Knopf, 1988)

Japikse, N., Correspondentie van Willem III en van Hans Willem Bentinck, eersten graaf van Portland, Serie 1, part 1, (Den Haag: Martinus Nijhoff, 1927)

Japikse, N., Correspondentie van Willem III en van Hans Willem Bentinck, eersten graaf van Portland, Serie 1, part 2, (Den Haag: Martinus Nijhoff, 1928)

Johnston, Jr., Stanley H. (ed), The Cleveland herbal, botanical, and horticultural collections: a descriptive bibliography of pre-1830 works from the Libraries of the Holden Arboretum, the Cleveland Medical Library Association, and the Garden Center of Greater Cleveland, (Kent: Kent State University Press, 1992)

Jong, E.A. de, "For profit and ornament: The function and meaning of Dutch garden art in the period of William and Mary, 1650-1702," J.D. Hunt (ed), The Dutch Garden in the Seventeenth Century, (Washington D.C.: Dumbarton Oaks, 1990), pp. 13-48

Jong, E.A. de, Natuur en Kunst, Nederlandse tuin- en landschapsarchitectuur 1650-1740, (Hilversum: Toth, 1995)

Jong, Erik de, Clemens Steenbergen and Peter de Zeeuw, "De Beemster. Een arena van natuur, kunst en techniek," Toon Lauwen (ed), Nederland als kunstwerk; Vijf eeuwen bouwen door ingenieurs, (Rotterdam: Nai Uitgevers, 1995), pp. 154-167

Jong, Johan de, "Drawings And Spices: Accumulation And Ships Of The Dutch East India Company," L.L. Roberts (ed), Centres and cycles of accumulation: Material and Knowledge production and exchange in and around the Netherlands during the early modern period, (forthcoming 2011)

Karsten, Mia, The Old Company's Garden at the Cape and its Superintendents; Involving an Historical Account of the Early Cape Botany, (Cape Town: Maskew Miller Ltd, 1951)

Karstens, W.K.H. and H. Kleibrink, De Leidse Hortus, een botanische erfenis, (Zwolle: Uitgeverij Waanders, 1982) 
BIBLIOGRAPHY

Kolb, Peter, Naaukeurige en uitvoerige beschryving van Kaap de Goede Hoop, (Amsterdam: B. Lakeman, 1727), 2 vols

Kölker, A.J., G.H. Keunen, and D. de Vries, De Beemster, (Alphen aan de Rijn: Canaletto, 1985)

Kooijmans, Luuc, De doodskunstenaar; De anatomische lessen van Frederik Ruysch, (Amsterdam: Bert Bakker, 2004)

Korthals Altes, J., Polderland in Italie; De werkzaamheden der Nederlandsche bedijkers in vroeger eeuwen en het Italiaansche polderland voorheen en thans, (Den Haag: Stockum, 1928)

Kuijlen, Jos, "De Danziger Botanicus en Koopman Jacob Breyne (1637-1697) en zijn betekenis voor de Hollandse Plantkunde," Tijdschrift voor de Geschiedenis der Geneeskunde, Natuurwetenschappen, Wiskunde en Techniek, 5 (1982), pp. 116-118

Kuile, G.J. ter, "Het graafschap Lingen onder de Oranjes," Verslagen en Mededeelingen van de Vereeniging tot Beoefening van Overijsselsch Regt en Geschiedenis, (s.1., 1953), pp. 13-31 Laan, P.H.J. van der, "The Poulle brothers of Amsterdam and the North Sea and Baltic trade, 1590-1620," W.G. Heeres, L.M.J.B. Hesp, L. Noordegraaf and R.C.W. van der Voort (eds), From Dunkirk to Danzig, Shipping and trade in the North Sea and the Baltic, 1350-1850, (Hilversum: Verloren Publishers, 1988), pp. 317-330

Latour, Bruno, "Give me a laboratory and I will raise the world," K. Knorr and M. Mulkay (eds), Science Observed: Perspective on the Social Study of Science, (Los Angeles: Sage, 1983), pp 141-170

Latour, Bruno, "Visualization and cognition: Thinking with the eyes and hands," Knowledge and Society: studies in the sociology of culture past and present, 6 (1986), pp. 1-40

Latour, Bruno, The Pasteurization of France, (Cambridge/London: Harvard University Press, 1993)

Latour, Bruno, Science in Action; How to follow Scientists and Engineers through Society, (Cambridge: Harvard University Press, 2003)

Lauterbach, Christiane, Gärten der Musen und Grazien, Mensch und Natur im niederländischen Humanistengarten 1522-1655, (Munchen/Berlin: Deutscher Kunstverlag, 2004)

Lauwen, Toon, Nederland als kunstwerk; Vijf eeuwen bouwen door ingenieurs, (Rotterdam: Nai Uitgevers, 1995)

Leeghwater, Jan Adriaansz., Haarlemmer-meer-boek, (Amsterdam: Pieter Visser, 1724)

Lefebvre, N., A compendious body of chemistry: teaching the whole practice thereof by the most exact preartion of animals, vegetables and minerals, preserving their essential virtues, (London: Tho. Davies and Theo. Sadler, 1664), 2 vols

Leibbrandt, H.C.V., Precis of the Archives of the Cape of Good Hope, Letters Despatched from the Cape, 1652-1662, to which are added land grants, attestations, journal of voyage to Tristan da Cunha, names of freemen etc., (Cape Town: W.A. Richards and Sons, 1900)

Lévi-Strauss, Claude, The Savage Mind, (Chicago: University of Chicago Press, 1968)

Lindblad, J. Th., "Evidence of Dutch-Swedish Trade in the 17th Century," J.Ph.S. Lemmink and J.S.A.M. van Koningsbrugge (eds), Baltic Affairs, Relations between the Netherlands and North-eastern Europe 1500-1800, (Nijmegen: INOS, 1990), pp. 205-228 
BIBLIOGRAPHY

Linebaugh, Peter and Marcus Rediker, The Many-Headed Hydra; Sailors, Slaves, Commoners, and the Hidden History of the Revolutionary Atlantic, (Boston: Beacon Press, 2000)

Livingstone, David N., Putting Science in its Place, Geography's of Scientific Knowledge, (Chicago/London: The University of Chicago Press, 2003)

Machen, W.C.H., Warmond voorheen en thans, de voormalige ridderhofstede te Warmond, tweede deel, (Leiden: N.V. "De Leidsche Courant", 1931)

MacPike, Eugene Fairfield, Hevelius, Flamsteed, and Halley: Three Contemporary Astronomers and Their Mutual Relations, (London: Taylor \& Francis, 1937)

Margocsy, Daniel, “'Refer to folio and number': Encyclopedias, the Exchange of Curiosities, and Practices of Identification before Linnaeus," Journal of the History of Ideas, 71 (2010), pp. 63-89

Marks, Shula, "Khoisan Resistance to the Dutch in the Seventeenth and Eighteenth Centuries," The Journal of African History, 13 (1972), pp. 55-80

Mayhew, Robert, "Mapping science's imagined community: geography as a Republic of Letters, 1600-1800,” British Journal of the History of Science, 38 (2005), pp. 73-92

Meister, George, Der Orientalisch-Indianische Kunst- und Lust-Gärtner, Friedemann Berger and Wilfried Bonsack (eds), (Weimar: Gustav Kiepenheuer Verlag, 1973)

Mentzel, O.F., A Geographical and Topographical Description of the Cape of Good Hope, (Cape Town: Van Riebeeck Society, 1921), 2 vols

Michel, Wolfgang, "Far Eastern Medicine in Seventeenth and Early Eighteenth Century Germany," Studies in Languages and Cultures, 20 (2005), pp. 67-82

Miller, Mara, The Garden as an Art, (Albany: State University of New York Press, 1993)

Miller, N., Heavenly Caves, reflections on the garden grotto, (New York: George Braziller, 1982)

Molhuysen, P.C., Bronnen tot de Geschiedenis der Leidsche Universiteit, 18 febr. 1682 - 8 febr. 1725, (Den Haag: Martinus Nijhoff, 1920)

Morton, A.G., History of Botanical Science, an account of the development of botany from ancient times to the present day, (London/New York/Toronto: Academic Press, 1981)

Morus, I. Rhys, "Seeing and believing science," Isis, 97 (2006), pp. 101-110

Mossop, E.E. (ed), Journals of the Expeditions of the Honourable Ensign Olof Bergh (1682 and 1683) and the Ensign Isaq Schrijver (1689), (Cape Town: Van Riebeeck Society, 1931)

Mukerji, Chandra, Territorial ambitions and the gardens of Versailles, (Cambridge: Cambridge University Press, 1997)

Mukerji, Chandra, "Storehouses to Stoves: Built Environments and the Early Dutch Plant Trade," an unpublished paper presented at the symposium "Dutch Culture in the Golden Age", (Philadelphia: University of Pennsylvania, 1999)

Mukerji, Chandra, "Material practices of dominion: Christian humanism, the built environment and techniques of western power," Theory and Society, 31 (2002) pp. 1-34

Muller, E. and K. Zandvliet, Admissies als landmeter in Nederland voor 1811. Bronnen voor de geschiedenis van de landmeetkunde en haar toepassing in administratie, architectuur, kartografie en vesting- en waterbouwkunde, (Canaletto: Alphen aan den Rijn, 1987) 
BIBLIOGRAPHY

Müller-Wille, Staffan, "Joining Lapland and the Topinambes in Flourishing Holland: Center and Periphery in Linnaean Botany," Science in Context, 16 (2003), pp. 461-488

Munting, Abraham, Nauwkeurige beschryving der aardgewassen, waar in de veelerley aarten bijzondere Eigenschappen der Boomen, Heesters, Kruyden, bloemen, (Leiden: Pieter van der Aa, 1696)

Munting, Abraham, Waare Oeffening der Planten, (Amsterdam: Jan Rieuwertsz, 1682)

Noordegraaf, Jan, "Omtrent Bronnen, Lambert ten Kate schrijft naar Dantsig Brieven aan Johann Philipp Breyne," De Achttiende Eeuw, 39 (2007), pp. 96-101

Ogilvie, Brian W., "The Many Books of Nature: Renaissance Naturalists and Information Overload," Journal of the History of Ideas, 64 (2003), pp. 29-40

Ogilvie, Brian W., The Science of Describing, Natural History in Renaissance Europe, (Chicago/London: The University of Chicago Press, 2008)

Otterspeer, Willem, Groepsportret met Dame I; Het bolwerk van de vrijheid; de Leidse universiteit 1575-1672, (Amsterdam: Bert Bakker, 2000)

Pols, Hans, "European Physicians and Botanists, Indigenous Herbal Medicine in the Dutch East Indies, and Colonial Networks of Mediation," East Asia Science, Technology and Society: an International Journal, 3 (2009), pp. 173-208

Pouls, H.C., De landmeter Jan Pietersz Dou en de Hollandse Cirkel, (Delft: Nederlandse Commissie voor Geodesie, 2004)

Prak, Maarten, Gouden Eeuw; Het raadsel van de Republiek, (Nijmegen: SUN, 2002)

Pratt, M.L., "Arts of the Contact Zone," D. Bartholomae and A. Petroksky (eds), Ways of Reading, (Boston/New York: Bedford-St. Martin's, 1999)

Prest, John, The Garden of Eden, the Botanic Garden and the Re-Creation of Paradise, (New Haven/London: Yale University Press, 1988)

Raven-Hart, R., Cape Good Hope 1652-1702, The First Fifty Years of Dutch Colonisation as seen by Callers, (Cape Town: A.A. Balkema, 1971), 2 vols

Reh, Wouter and Clemens Steenbergen (eds), Zee van land. De droogmakerij als architectonisch experiment, (Delft: Technische Universiteit, 1999)

Rhyne, William ten, "A Short Account of the Cape of Good Hope and if the Hottentots who inhabit that region," I. Schapera and E. Farrington (eds), The Early Cape Hottentots, (Westport: Negro Universities Press, 1970), pp. 81-157

Rijken, Henk, Leidse Lustwarande Geschiedenis van de tuinkunst op kastelen en buitenplaatsen rond Leiden, 1600 - 1800, (Leiden: Primavera Pers, 2005)

Roberts, Lissa L., "A World of Wonders, a World of One," Pamela Smith and Paula Findlen (eds), Merchants and Marvels: Commerce, Science and Art in Early Modern Europe, (New York/London: Routledge, 2002), pp 399-411

Roberts, Lissa L. and Simon Schaffer, "Preface," Peter Dear, Simon Schaffer, and Lissa Roberts (eds),The Mindful Hand: inquiry and invention from the late Renaissance to early industrialization, (Amsterdam: Edita, 2007), pp. xiii-xxvii

Roberts, Lissa L., "Situating Science in Global History Local Exchanges and Networks of Circulation," Itinerario, 33 (2009), pp. 1-19 
BIBLIOGRAPHY

Roberts, Lissa L., "Introduction: Transcending Boundaries: Mindful Hands in the History of Technology," History of Technology, 29 (2009), pp. 105-112

Roever, J.G. de, Jan Adriaenszoon Leeghwater, het leven en werk van een zeventiende-eeuws waterbouwkundige, (Amsterdam: Wed. J. Ahrend, 1944)

Roob, Helmut and Cornelia Hoff, Jacob und Johann Philipp Breyne, zwei Danziger Botaniker im 17. und 18. Jahrhundert, (Gotha: Veröffentlichungen der Forschungsbibliothek Gotha, 1988) vol. 27

Roorda, D.J., "De loopbaan van Willem Meester,” Spiegel Historiael, 16 (1981), pp. 614-622

Saridakis, Voula, "Establishing an astronomical network from Danzig: Johannes Hevelius' exchange with the European scientific community," M. Kokowski (ed), The Global and the Local: The History of Science and the Cultural Integration of Europe, (Cracow: 2008), pp. 228-232. Electronically available: www.2iceshs.cyfronet.pl/2ICESHS_Proceedings/ Chapter_10/R-2_Saridakis.pdf

Schaffer, Simon, Lissa Roberts, Kapil Raj and James Delbourgo (eds), The Brokered World, Go-Betweens and Global Intelligence, 1770-1820, (Sagamore Beach: Watson Publishing International, 2009)

Schiebinger, Londa, "Maria Winkelmann at the Berlin Academy: A Turning Point for Women in Science," Isis, 78 (1987), pp. 174-200

Scheibinger, Londa, Plants and Empire, Colonial Bioprospecting in the Atlantic World, (Cambridge/London: Harvard University Press, 2004)

Schiebinger, Londa and Claudia Swan (eds), Colonial Botany, Science, Commerce, and Politics in the Early Modern World, (Philadelphia: University of Pennsylvania Press, 2005)

Schoeman, K., Armosyn van die Kaap, die wêreld van 'n slavin, 1652-1733, (Cape Town: Human \& Russeau, 2001)

Scholtz, J. du P., Naamgewing aan Plante en Diere in Afrikaans, bydrae tot 'n geskiedenis van die Afrikaanse woordeskat, (Elsiesrivier: Nasou Beperk, 1974)

Schotel, G.D.J., Iets over Hieronymus van Beverningh en Bruno van der Dussen, (Den Bosch: Gebr. Muller, 1847)

Schreiber, G., Der Bergbau in Geschichte, Ethos und Sakralkultur, (Cologne: Westdeutscher Verlag, 1955)

Schreyer, Johann, "Reise nach dem Kaplande und Beschreibung der Hottentotten, 16691677," S.P. L'Honoré Naber (ed), Reisebeschreibungen von Deutschen Beamten und Kriegsleuten im Dienst der Niederländischen West- und Ost-Indischen Kompagnien 1602-1797, (Den Haag: Martinus Nijhoff, 1930-1932), 13 vols, vol. 7, pp. 114-139

Schuyl, Florentius, Catalogus plantarum Horti Academici Lugduno-Batavi, (Leiden: Johannis Elsevirii, 1668)

Schweikardt, Christoph, "More than just a Propagandist for Tea: Religious Argument and Advice on a Healthy Life in the Work of the Dutch Physician Cornelis Bontekoe (16471685)," Medical History, 47 (2003), pp. 357-368

Secord, James A., "Knowledge in Transit," Isis, 95 (2004), pp. 654-672 
BIBLIOGRAPHY

Shapin, Steven, and Simon Schaffer, Leviathan and the air-pump: Hobbes, Boyle, and the experimental life, (Princeton: Princeton University Press, 1989)

Shapin, Steven, "The House of Experiment in Seventeenth-Century England," Isis, 79 (1988), pp. 373- 404

Shapin, Steven, A Social History of Truth; Civility and Science in Seventeenth-Century England, (Chicago/London: The University of Chicago Press, 1994)

Shapin, Steven, The Scientific Revolution, (Chicago: University of Chicago Press, 1996)

Shapiro, A.E., "Huygens' kinematic theory of light," H.J.M. Bos, M.J.S. Rudwick et.al. (eds), Studies of Christiaan Huygens, Invited Papers from the Symposium on the Life and Work of Christiaan Huygens, (Lisse: Swets and Zeitlinger, 1980), pp. 200-220

Shapiro, A.E., "Huygens' "Traité de la Lumière" and Newton's "Opticks": pursuing and eschewing hypotheses," Notes and Records of the Royal Society of London, 43 (1989), pp. 223-247

Sikkens-de Zwaan, Marisca, "Magdalena Poulle (1632-99): a Dutch lady in a circle of botanical collectors," Garden History; Journal of the Garden History Society, 30 (2002), pp. 202-220

Silva, Maria Angélica da and Melissa Mota Alcides, "Collecting and Framing the Wilderness: The garden of Johan Maurits (1604-79) in North-East Brazil," Garden History; Journal of the Garden History Society, 30 (2002), pp. 153-176

Skott, Christina, "The VOC and Swedish natural history: The transmission of scientific knowledge in the eighteenth century," Siegried Huigen, Jan L. de Jong and Elmer Kolfin (eds), The Dutch trading Companies as Knowledge Networks, (Leiden/Boston: Brill Publishers, 2010), pp. 361-392

Smith, Pamela, The Body of the Artisan, Art and Experience in the Scientific Revolution, (Chicago: University of Chicago Press, 2004)

Smith, Pamela and Paula Findlen (eds), Merchants and Marvels: Commerce, Science and Art in Early Modern Europe, (New York/London: Routledge, 2002)

Smith, Woodruff D., "The Function of Commercial Centers in the Modernization of European Capitalism: Amsterdam as an Information Exchange in the Seventeenth Century," The Journal of Economic History, 44 (1984), pp. 985-1005

Söderlund, Inga Elmqvist, Taking Possession Of Astronomy; Frontispieces And Illustrated Title Pages In 17th-Century Books On Astronomy, (Stockholm: The Center for History of Science at the Royal Swedish Academy of Sciences, 2010)

Spary, E.C., "Scientific symmetries," History of Science: an annual review of literature, research and teaching, 42 (2004), pp. 1-46

Stafford, B.M. and F. Terpak, Devices of Wonder: From the World in a Box to Images on a Screen, (Los Angeles: Getty Research Institute, 2001)

Star, Pieter van der (ed), Fahrenheit's Letters to Leibniz and Boerhaave, (Amsterdam: Rodopi, 1984)

Stevin, Simon, Wisconstich filosofisch bedryf, (Leiden: Philips de Croy, 1667)

Stevin, Simon, Materiae Politicae, (Leiden: Adryaen Rosenboom, s.d.) 
BIBLIOGR APHY

Stock, J.L.W., "The Diary of a Cattle Expedition among the Hottentots in 1707," The English Historical Review, 31 (1916), pp. 610-622

Streefkerk, Chris, Jan Werner, and Frouke Wieringa (eds), Perfect Gemeten, Landmeters in Hollands Noorderkwartier ca. 1550-1700, (Alkmaar: Stichting Uitgeverij Noord-Holland, 1994)

Subrahmanyam, Sanjay, "Rural Industry and Commercial Agriculture in Late SeventeenthCentury South-Eastern India," Past and Present, 126 (1990), pp. 76-114

Suhling, L., Aufschließen, Gewinnen und Förderen; Geschichte des Bergbaus, (Reinbek: Rowohlt, 1983)

Swan, Claudia, "Collecting Naturalia in the Shadow of Early Modern Dutch Trade," Londa Schiebinger and Claudia Swan (eds), Colonial Botany, Science, Commerce, and Politics in the Early Modern World, (Philadelphia: University of Pennsylvania Press, 2005), pp. 223236

Szafranska, M., "The philosophy of nature and the grotto in the Renaissance garden," Garden History; Journal of Garden History, 9 (1989), pp. 76-85

Tachard, Guy, Voyage to Siam, (Bangkok: Orchid Press, 1999)

Taverne, Ed, In 't land van belofte: in de nieue stadt; Ideaal en werkelijkheid van de stadsuitleg in de Republiek 1580-1680, (Maarssen: Gary Schwartz, 1978)

Taylor-Leduc, S., “A new treatise in seventeenth-century garden history: André Félibien's 'Description de la Grotte à Versailles'," Studies in the History of Gardens \& Designed Landscapes, 18 (1998), pp. 35-50

Temple, R.C. (ed.), The Papers of Thomas Bowrey 1669-1713, (London: Hakluyt Society, 1927)

Tielhof, Milja van, The 'mother of all trades'; The Baltic grain trade in Amsterdam from the late 16th to the early 19th century, (Leiden/Boston/Cologne: Brill Publishers, 2002)

Tielhof, Milja van, De Hollandse graanhandel, 1470-1570; Koren op de Amsterdamse Molen, (Den Haag: Hollandse Historische Reeks, 1995), vol. 23

Turnbull, D., "Boundary-Crossings, Cultural Encounters and Knowledge Spaces in Early Australia," Simon Schaffer, Lissa Roberts, Kapil Raj and James Delbourgo (eds), The Brokered World, Go-Betweens and Global Intelligence, 1770-1820, (Sagamore Beach: Watson Publishing International, 2009), pp. 387-428

Valentyn, F., Beschryvinge van de Kaap der Goede Hoope met de zaaken daar toe behorende, P. Serton, R. Raven-Hart and W.J. de Kock (eds), (Cape Town: Van Riebeeck Society, 1971)

Veendorp, H. and L. Baas Becking, Hortus Academicus Lugduno Batavus, the development of the gardens of Leyden University 1587-1937, (Haarlem: Joh. Enschedé, 1938)

Ven, G.P. van de (ed), Man-made Lowlands; History of water management and land reclamation in the Netherlands, (Utrecht: Matrijs, 2004)

Vérin, Hélène, "Technology in the Park: Engineers and Gardeners in Seventeenth-Century France," Monique Mosser and Georges Teyssot (eds), The Architecture of Western Gardens; A Design History from the Renaissance to the Present Day, (Cambridge: The MIT Press, 1991), pp. 135-146 
BIBLIOGRAPHY

Verstegen, M., De Indische Zeeherberg, De stichting van Zuid-Afrika door de VOC, (Zaltbommel: Europese Bibliotheek, 2001)

Vertesi, Janet, "Instrumental images: the visual rhetoric of self-presentation in Hevelius's Machina Coelestis," British Society for the History of Science, 43 (2010), pp. 209-243

Verwaal, Ruben E., Hippocrates Meets the Yellow Emperor; On the Reception of Chinese and Japanese Medicine in Early Modern Europe, 1650-1750, (Utrecht: Utrecht University, 2009), master thesis, electronically available: http://igitur-archive.library.uu.nl/student-theses/2010-0812-200203/UUindex.html

Vries, Jan de, and Ad van der Woude, Nederland 1500-1815, De eerste ronde van moderne economische groei, (Amsterdam: Balans, 2005)

Vondel, Joost van den, "De Beemster, voor Karel Looten," Verscheide gedichten, (Amsterdam: Jacob Lescaille, 1644), pp. 342-43, electronically available http://www.dbnl.org/tekst/ vond001dewe04/vond001dewe04_0125.htm

Waterhouse, G. (ed), Simon van der Stel's Journal of his expedition to Namaqualand, 1685-6, (London/New York/Toronto: Longmans, Green, 1932)

Wells, Julia C., "Eva's Men: Gender and Power in the Establishment of the Cape of Good Hope, 1652-74," The Journal of African History, 39 (1998), pp. 417-437

White, R., The Middle Ground, Indians, Empires, and republics in the Great Lakes Region, 1650-1815, (Cambridge/London: Cambridge University Press, 2007)

Wijnands, D.O., The Botany of the Commelins, (Rotterdam: A.A. Balkema, 1983)

Wijnands, D.O., "Hortus auriaci: de tuinen van Oranje en hun plaats in de tuinbouw en plantkunde van de late zeventiende eeuw/Hortus auriaci: the gardens of Orange and their place in late 17th-century botany and horticulture," Journal of Garden History, 8 (1988), pp. 61-86

Wijnands, D.O. and E.J.A. Zevenhuizen, J. Heniger, Een Sieraad voor de Stad, de Amsterdamse Hortus Botanicus 1638-1993, (Amsterdam: Amsterdam University Press, 1994), pp. 70-74

Wijnands, D.O., M.L. Wilson and T. Toussaint van Hove, Jan Commelin's Monograph on Cape Flora, (Stellenbosch: University of Stellenbosch Printers, 1996)

Wilson, M.L., Th. Toussaint van Hove-Exalte and W.J.J. van Rijssen (eds), Codex Witsenii, (Cape Town/Amsterdam” Davidii Media, 2002)

Winter, P.J. van, Hoger beroepsonderwijs avant-la-lettre. Bemoeiingen met de vorming van landmeters en ingenieurs bij de Nederlandse universiteiten van de $17^{e}$ en $18^{e}$ eeuw, Series: Verhandelingen der Koninklijke Nederlandse Akademie van Wetenschappen, afd. Letterkunde, (Amsterdam/Oxford/New York: Noord-Hollandsche Uitgevers Maatschappij, 1988) vol. 137

Wittop Koning, D.A., De Handel in Geneesmiddelen te Amsterdam tot omstreeks 1637, (Purmerend: J. Muusses, 1942)

Woelderink, B., "Het bezoek van Simon Stevin aan Dantzig in 1591," Tijdschrift voor de geschiedenis der Geneeskunde, Natuurwetenschappen, Wiskunde en Techniek, 3 (1980), pp. 178-186 
BIBLIOGRAPHY

Wolff, A., De bedyking van de Beemster, in dichtmaet uitgesproken, op Beemsterdankdag door Adrianus Wolff, predikant in de Beemster, (Hoorn: Tjallingius, 1773)

Zilsel, Edgar, "The social roots of science," Diederick Raven, Wolfgang Krohn, and Robert S. Cohen (eds), The Social Origins of Modern Science, (Dordrecht: Kluwer Academic Publishers, 2000), pp. 3-6 